Religion \& Culture in the Middle Ages

\title{
Ancrene Wisse \\ From Pastoral Literature \\ to Vernacular Spirituality
}

\section{Cate Gunn}

\section{University of Wales Press}



RELIGION AND CULTURE IN THE MIDDLE AGES

Ancrene Wisse 


\section{Teligion sculture themiddle ages -}

Series Editors

Denis Renevey (University of Lausanne)

Diane Watt (University of Wales, Aberystwyth)

Editorial Board

Miri Rubin (Queen Mary, University of London)

Jean-Claude Schmitt (École des Hautes Études en Sciences Sociales, Paris)

Fiona Somerset (Duke University)

Christiania Whitehead (University of Warwick) 
RELIGION AND CULTURE IN THE MIDDLE AGES

\section{Ancrene Wisse}

From Pastoral Literature to

Vernacular Spirituality

CATE GUNN

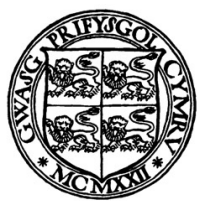

UNIVERSITY OF WALES PRESS

CARDIFF

2008 
(C) Cate Gunn, 2008

All rights reserved. No part of this book may be reproduced, stored in a retrieval system, or transmitted, in any form or by any means, electronic, mechanical, photocopying, recording or otherwise, without clearance from the University of Wales Press, 10 Columbus Walk, Brigantine Place, Cardiff, CF10 4UP.

www.uwp.co.uk

British Library Cataloguing-in-Publication Data

A catalogue record for this book is available from the British Library.

ISBN 978-0-7083-2034-1

The right of Cate Gunn to be identified as author of this work has been asserted by her in accordance with sections 77 and 78 of the Copyright, Designs and Patents Act 1988.

Typeset by Columns Design, Reading Printed in Great Britain by Antony Rowe Ltd, Wiltshire 


\section{A Note on Translations}

I am very grateful to Bella Millett for permission to use her translation of Ancrene Wisse.

I have quoted the later medieval English texts in the original Middle English. Modern translations are readily available; Walter Hilton's The Scale of Perfection is translated as The Ladder of Perfection by Leo Sherley-Price and published by Penguin; there are many modern versions of Julian of Norwich's work, including Showings, translated by Edmund Colledge and James Walsh, in the 'Classics of Western Spirituality' series published by SPCK.

Where possible, I have used published translations of Latin passages, and provided the text of the original Latin in the notes. Where no other translator is mentioned, the translations are my own.

I have translated passages from French with the help of Christopher Harris, and have had help with the occasional Dutch from Janet Potterton.

Other acknowledgements of help are made in the notes.

For the sake of consistency and clarity, I have used English versions of names throughout the text; so James of Vitry and James of Varazze, not Jacques de Vitry and Jacobus de Voragine. French or Latin versions of names may appear in the end notes.

I would like to acknowledge the emotional, and financial support of my husband, Tim Everitt. 



\section{Contents}

Part I The religious context

1 The Fourth Lateran Council 19

2 Eucharistic theology 30

3 The female religious movement: anchorites
and beguines

4 Anchoritic spirituality $\quad 50$

5 Lay piety 62

Part II Pastoralia and vernacular pastoral literature

6 Pastoralia 91

7 The rhetoric of preaching 99

8 Beguine sermons 110

9 Pastoral literature 119

Part III Ancrene Wisse: text and context

10 The rhetoric of Ancrene Wisse 139

i. Structure 139

ii. Exempla and similitudines 151

11 Ancrene Wisse: asceticism and contemplation 159

12 Reading Ancrene Wisse as vernacular spirituality 175

Conclusion $\quad 208$

Bibliography 211

Index 235 



\section{Introduction}

Ancrene Wisse is a religious prose work, dealing with matters that are both spiritual and devotional, written in English in the first half of the thirteenth century. It uses Latin sources, in terms of both its rhetoric and its pastoral material, while also anticipating the vernacular spirituality that developed in the fourteenth century. It was originally written at the request of three sisters who were following a reclusive life as anchoresses; in the Preface, the author directly addresses this initial audience: 'And you, my dear sisters, have been asking me for a long time for a rule'. ${ }^{1}$ I am quoting here from the version of Ancrene Wisse found in the Corpus Christi College, Cambridge, manuscript; although this is not the earliest of the extant versions of Ancrene Wisse (none of which is the original), it appears to date from the second quarter of the thirteenth century and is generally considered a high quality text. The revisions in this text are believed to be authorial, ${ }^{2}$ and it is the text chosen for recent editions and translations. ${ }^{3}$ The version of Ancrene Wisse found in another early manuscript, Cotton MS Nero A.xiv, also believed to belong to the second quarter of the thirteenth century, contains an extended reference to the three sisters and their circumstances:

You, my dear sisters, are the anchoresses that I know who have the least need of support against these temptations, with the sole exception of sickness; because I do not know of any anchoress who has all she needs with more ease or more respect than you three have ... Each of you has from one friend all that she needs; the maid does not have to look further for provisions than at his hall ... You are much talked about, what well-bred women you are, sought after by many for your goodness and for your kindness, and sisters from one father and one mother, who in the bloom of your youth renounced all the joys of the world and became recluses. ${ }^{4}$ 
This passage is omitted in the Corpus Christi version, which does, however, include a reference to an extended number of anchoresses, 'twenty now or more', all living in unity, as though in a single community. ${ }^{5}$ E. J. Dobson points out that there are also references to a single, hypothetical anchoress, ${ }^{6}$ and suggests that the revisions tend to omit personal details. ${ }^{7}$ Not only does the author adapt his text for more anchoresses than the original sisters known to him, but it is also clear that the author always presumed there would be a wider readership for Ancrene Wisse.

First we need to be clear what we mean by 'Ancrene Wisse': Ancrene Wisse is the only title for this guide to the anchoritic life with medieval authority, being the title found in the Corpus Christi manuscript; Ancren Riwle was an invention of James Morton for his 1853 edition of the text in MS Nero A.xiv - the first modern edition of Ancrene Wisse. The title Ancrene Wisse is sometimes used to indicate the version found in the Corpus Christi manuscript, but literary scholars are tending now to use it to indicate the work as a whole, rather than any particular redaction, and I am following this custom. By 'the work' I mean, not some urversion floating around in a hypothetical Platonic heaven of ideal texts, nor even the original inaccessible text, even if that could be reconstructed, but rather an evolving and variable work existing in many different versions, some of which will be preferable over others, depending on the purpose for which it is being read. The very history of textual transmission subverts the assumed primacy of authorial intention, and indeed the very idea of authorial intention as paramount is called into question when the author himself seems to have accepted the evolution and textual instability of his work, valuing functionality over 'textual integrity'. ${ }^{8}$ The variety in texts, each having interesting variations, and all requiring attention, is one indication of the complex nature of this work; but even in a single redaction, such as that in Corpus Christi 402, there is a complexity, due to its essentially multifunctional nature. Ancrene Wisse always contained within itself different functions and the possibility of being used by different readers and audiences. The fact that a choice has to be made over texts raises interesting 
issues, including that of audience and the relationship of the author to his readers.

The anchoresses at whose request Ancrene Wisse was written were leading an enclosed, contemplative life, but much of the advice given in the text was applicable to the wider community of pious laity living in the world. The greater part of Part Five, on confession, for example, is addressed to this larger audience, only the final short section being specifically for the use of the anchoresses: 'My dear sisters, this fifth part, which is about confession, is relevant to everybody alike; so do not be surprised that I have not spoken to you in particular in this part. But here is a short final section for your use. ${ }^{9}$

Even the sexual practices that are forbidden in Part Four, on temptation, are ones that need not concern the anchoresses the author knows, and of whose chastity he seems confident: 'Those of you who know nothing about such things need not wonder or speculate on what I mean, but give thanks to God that you have not experimented with such filthy practices, and feel sorry for those who have fallen into them.' 10 This qualification is found only in Corpus Christi and could be addressing the wider audience of anchoresses as well as the original three; the rest of the passage, however, detailing the offspring of the scorpion of lechery, and exhibiting a reticence to even name unnatural vices, lest 'someone might learn more wickedness than she knows already', ${ }^{11}$ is found in all the early versions, showing that even here the author was including material not relevant to the three sisters. In Part Five, on confession, where sexual sins are again alluded to, women other than anchoresses are mentioned: 'a woman should confess saying, I am an anchoress; a nun; an unmarried girl; a woman in whom great trust was placed; a woman who has burnt her fingers in the same way before and should have been better prepared against it. ${ }^{12}$

It is not only with reference to sexual sins that the separation of the anchoresses from the more general audience becomes clear - though the assumption of sexual purity on the part of the anchoresses was of great importance. The anchoresses for whom Ancrene Wisse was written are inscribed within the text as models of anchoritic behaviour: their bodies are frail vessels 
containing the precious fluid of their virginity, ${ }^{13}$ which is best preserved in the solitude and enclosure of the anchorhold. There is, however, much that devout lay people, living in the world, can also gain from reading Ancrene Wisse; the evidence for this lies in the widespread transmission of the text and its presence in manuscripts not intended for religious readers. It is this textual history that establishes Ancrene Wisse as an important work of vernacular spirituality, that is, devotional or spiritual writing in the vernacular that was accessible to lay readers as well as religious.

It is now accepted that Ancrene Wisse was originally written in English, the dialect suggesting composition in the West Midlands. ${ }^{14}$ The earliest extant English manuscripts of Ancrene Wisse (Cambridge, Corpus Christi College, 402; Cambridge, Gonville and Caius College, 234/120; London, British Library, Cotton Cleopatra C.vi; London, British Library, Cotton Nero A.xiv; London, British Library, Cotton Titus D.xviii) date from the first half of the thirteenth century, ${ }^{15}$ and internal evidence, although not conclusive, suggests composition after the Fourth Lateran Council of 1215. The questions of dating and authorship are interdependent: E. J. Dobson's conclusion that 'it seems that Ancrene Wisse might well have been written in or shortly after the period, between 1215 and 1222, when the bishops and abbots were promulgating the Lateran decrees in England' 16 is now generally accepted and has opened up the debate on authorship. The bishops who published constitutions containing decrees of the Fourth Lateran Council were those bishops who had themselves been present at the Council, or who had close contact with someone who had been present. These included the bishops of dioceses in the West Midlands, such as Alexander Stavensby. Stavensby, a Dominican, was Bishop of Coventry and Lichfield from 1224, and issued a set of diocesan constitutions with a reforming programme that quoted from the Fourth Lateran Council. He had not been present at the Council, but his predecessor at Coventry and Lichfield, William of Cornhill, had, and there is evidence that he brought back copies of the decrees from the Council. In Worcester, the set of decrees published in 1219 contained 'several of the Lateran Decrees', and while no current Bishop 
of Worcester had been at the Council, the Prior of Worcester, Sylvester of Evesham, was there, and he was elected Bishop of Worcester in the following year. ${ }^{17}$ There is evidence, therefore, that the bishops of the dioceses in which Ancrene Wisse was probably written were actively involved in promoting the reforms decreed at the Fourth Lateran Council.

The early texts of Ancrene Wisse provide useful dating information; for example, the favourable mention of friars in the Corpus Christi $402^{18}$ manuscript means that this version cannot have been made before the friars arrived in England, the Dominicans in 1221 and the Franciscans in 1224; both Franciscans and Dominicans established houses in the West Midlands in the decade following this. Dobson's argument that the revisions in this text are authorial also helps with the dating of the work itself, which could not have been composed too long before this revision, since 'both must come within the working life of a single author' ${ }^{19}$ Dobson suggested that the author of Ancrene Wisse was a member of Wigmore Abbey, a house of Victorine canons in Herefordshire. ${ }^{20}$ However, Bella Millett has argued persuasively that, where the author makes a specific reference to the order to which he belongs, although he never names that order, the details are most consistent with Dominican or Premonstratensian practices; ${ }^{21}$ Dominican constitutions drew on the Premonstratensian model. What Millett did not find was evidence of the Victorine authorship essential for Dobson's hypothesis. If the author were himself a Dominican it may seem odd that the reference to friars preachers occurs only in the later Corpus Christi version of the work; it is possible that he had joined the Order abroad, and that at the time of his writing no house of Dominican friars had been established in the West Midlands.

While particular details of customs, liturgical practices and so on provide valuable evidence for the date of composition and institutional context, the general tenor of the work is also of great importance: in Ancrene Wisse there is an emphasis on penitence and confession which is consistent with Dominican authorship, since Dominicans - members of the Order of Preachers - were charged with pastoral duties. ${ }^{22}$ Hearing confession and imposing penance, as well as the preaching of sermons, were the opportunities for clerics - secular or religious 
- to influence, instruct and educate the lay people in their care. Ancrene Wisse deals with issues that were increasingly of concern to pious lay people, and those entrusted with their spiritual charge, at a time when more lay people - including the sisters who became anchoresses - were seeking a religious vocation outside the traditional forms of religious life.

The author was aware of the particular state of education of the three well-born sisters for whom Ancrene Wisse was originally composed: they were women who were educated sufficiently well to be able to read their native language, English, and to have some understanding of Latin and French: prayers are given in Latin, and they are advised to occupy their time 'Reciting versicles from the Psalter, reading in English or in French'. ${ }^{23}$ They were not illiterate, but nor were they fully litteratae, in the sense of being educated in Latin; ${ }^{24}$ in the Middle Ages, to be litteratus usually was understood to mean to be clericus. ${ }^{25}$ In Ancrene Wisse provision is made in the observances of the 'Outer Rule', described in Part One, for those without the learning of the anchoresses: 'Anyone who does not know these five ...' and 'Whoever does not know any other form of Matins ...'26 Provision is made in both the original and later versions of Part One 'for a much-simplified devotional routine based on repeated Paters and Aves'. ${ }^{27}$ Even those who could not read Ancrene Wisse themselves but would have had it read to them had access to this devotional material, and are, indeed, inscribed within it. In Part Eight of Ancrene Wisse, which, with Part One, forms the Outer Rule and frames the Inner Rule, the needs and requirements of the servant of the anchoress are addressed: if she is illiterate, 'ne con o boke', ${ }^{28}$ she should say Pater Nosters and Aves at the Hours, and the anchoresses are instructed to read the section that deals explicitly with the devotions and behaviour of the servants once a week so that they may learn it. ${ }^{29}$ The Inner Rule, however, is for those - anchoresses and devout laity who have the learning to con it.

It is in the nature of medieval texts - copied over the years by scribes who either had views of their own on the text, or who did not understand it - that they should vary and be adapted for different circumstances and readers. This variability is not a defect, but can be considered an attribute; 
it is often referred to as mouvance, a term Millett, with reference to Paul Zunthor, defines as the 'essential textual instability or fluidity' that is 'an important characteristic of much medieval literature'. ${ }^{30}$ Barbara Newman reminds us that Aelred's anchoritic guide for his sister, known as the $D e$ Institutione Inclusarum, was 'frequently abridged, translated, and incorporated into other rules; manuscripts of the text found their way into Augustinian, Benedictine, Carthusian, Cistercian and Franciscan houses'. ${ }^{31}$ The author of Ancrene Wisse acknowledged the influence of Aelred's guide, and parts are incorporated into the later work, while a Middle English version of De Institutione Inclusarum is found in the Vernon manuscript, as is a version of Ancrene Wisse. Alexandra Barratt claims that De Institutione Inclusarum was 'subject to the usual sort of mouvance experienced by such texts'. ${ }^{32}$ Nevertheless, I want to suggest that Ancrene Wisse was different: it was the product of profound social and religious movement - the period itself was mouvant. This movement, or transition, is evident in the language, doctrine and rhetoric of the texts. The significance of the fact that Ancrene Wisse was written in English, suggesting a new, post-Conquest, acceptability and use for the English language, has led to its established position in literary and philological studies, but the language used cannot yet be considered stable; ${ }^{33}$ the text makes use of borrowings from French, inventing English neologisms. The Church doctrine incorporated in the work shows evidence of the new pastoral thinking at the time of the Fourth Lateran Council, while the rhetoric owes much to the new sermon rhetoric developing in Paris towards the end of the twelfth century. This book is concerned to show that Ancrene Wisse needs to be read within this context of religious change and linguistic fluidity.

Many recent studies of Ancrene Wisse have been concerned with it as an anchoritic guide and with how its discourse constructs its readership of female recluses; this is a trend that started with Janet Grayson's study of the structure and imagery of Ancrene Wisse ${ }^{34}$ and, more particularly, Linda Georgianna's siting of Ancrene Wisse in the context of twelfth-century humanism: Georgianna claims that 'the text [Ancrene Wisse] is central to our understanding of the period's 
interest in the individual'. ${ }^{35}$ Ancrene Wisse has been read as a text written specifically for enclosed women: there has been much discussion on the body and domestic imagery used, and whether it reveals a specifically feminine spirituality. ${ }^{36}$ In reading Ancrene Wisse, we encounter the body - symbolic and physical - as a fragile vessel containing a previous treasure, as the site of a battle against the devil, as the enclosure of the anchoress, and as the enclosed anchoress herself. Anne Savage insists that, whatever wider readership Ancrene Wisse and the works associated with it eventually attained, they were composed only for a 'limited and extremely specialized readership', and that consequently the spirituality defined a 'very narrow range'; 37 however, this seems to be ignoring the inscription within the texts of other readers, and may be giving authorial intention more weight than is useful in a reading of the texts. There is continuing interest in the internal space of the anchorhold - for instance, in a number of the essays in the forthcoming Rhetoric of the Anchorhold, ${ }^{38}$ but I am taking the anchoress out of her isolation in the cell. This move is seen also in some recent studies of Ancrene Wisse, such as some of the essays in the 2003 Companion to Ancrene Wisse ${ }^{39}$ which are concerned with the work in the context of religious reform and its later readership, and with the transmission of the text in wider lay circles.

In following the line taken by some of the contributors to the Companion, such as Nicholas Watson and Catherine InnesParker, and reading Ancrene Wisse as a work of vernacular spirituality always open to a wider - and not necessarily female - readership, I am necessarily challenging views of its spirituality as peculiarly female. Barbara Newman suggests that, in the 'casual antifeminism' found in the literature of spiritual formation, 'female' was used as 'a sign for all that was considered weak and inferior' 40 - and that this could apply to texts directed at men. At the same time, female figures could be used as positive models for men: the figure of Judith is used in Ancrene Wisse to represent confession, cutting off the head of sin, Holofernes; but this is not a gender-specific image. Odo of Cheriton and Thomas of Chobham in the early thirteenth century, Aelred of Rievaulx in the twelfth and Peter Damian in the eleventh, all use the figure of Judith as a model for their 
male readers. ${ }^{41}$ Even Bernard, in a sermon to a male monastic community, mentions Judith who, 'although a woman, triumphed over her enemies. ${ }^{42}$ While acknowledging that 'Nuns were consistently imagined, and encouraged to imagine themselves, in gender-specific roles based on the sexuality they were renouncing', Newman points out that

Insofar as the religious ideal transcended gender, works addressed to men or to women could be read and used freely by religious of both sexes ... The essential monastic virtues of humility, poverty, obedience, abstinence, discretion, and charity are the same for both sexes ... Men as well as women are to perceive themselves as Christ's brides; women as well as men are to fight in Christ's army. ${ }^{43}$

Caroline Walker Bynum has argued in an essay on 'The female body and religious practice' that 'medieval thinkers used gender imagery fluidly, not literally': it was not uncommon for female imagery and models to be used of and for men. ${ }^{44}$ While religious women may be constructed in gendered ways and through gendered imagery, the texts written for them were not inescapably confined by that gender identification. This needs to be kept in mind if we are to consider the spirituality, not just of the anchoresses, but of Ancrene Wisse itself.

In constructing a spirituality that was incarnational and penitential, Ancrene Wisse drew on a monastic and, specifically, Cistercian tradition of spirituality, making use of mystical treatises and sermons; but it also drew from its contemporary social and religious context, and we need to acknowledge how far the spiritual attitudes of the work were conditioned by the society in which, and for which, it was written. Many different influences fed the soil out of which the complex work that is Ancrene Wisse grew; these include the development of radical religious groups such as the beguines, the pastoral mission of mendicant friars, and the spread of affective piety into the devotional practices of lay people. Affective piety was expressed in such practices as devotion to the Eucharist and to the Virgin Mary, and in the desire to imitate the human, suffering Christ through a life of penitence. It was in this rich soil that the heart could be cultivated in its relationship with God. Reading Ancrene Wisse within this 
context of a piety shared by laity and religious, its place in the history of vernacular spirituality becomes apparent.

The author was aware of the need to adapt his material for his audience; as Bernard of Clairvaux had acknowledged, different audiences require, not so much different things to be said, but rather that those things be said in a different way. ${ }^{45}$ Gregory the Great made a similar point in his advice to preachers: 'the medicine which diminishes this disease, increases the strength of another; and bread which strengthens the life of the strong, destroys that of young children' ${ }^{46}$ Much of the material in Ancrene Wisse had its origins in a monastic tradition, but the author of Ancrene Wisse was not writing for a monastic audience, and broke up his material to make it palatable:

And I have broken them all up for you, my dear sisters, as people do for children who might die of hunger with unbroken bread. But be sure that I have let fall many crumbs; look for them and gather them up, because they are food for the soul. ${ }^{47}$

This is from Part Five of Ancrene Wisse, and it is the necessary elements of confession that have been broken up: here, as elsewhere, doctrines of the Church are made accessible to a lay readership and, in a reference to the parable of the Canaanite woman who was rewarded for her faith and persistence (Matthew 15: 22-8), crumbs fall from the tables of clerics and religious to provide soul food for the anchoresses. The author of Ancrene Wisse felt it necessary to provide food for the soul in an appropriate form for his readers; in Ancrene Wisse, he was providing spiritual nourishment, not only for the anchoresses, but for other literate people - both those within cloisters and those who wanted to follow a life of devotion and piety outside traditional religious orders. The author of Ancrene Wisse was consciously writing in a tradition of pastoral literature aimed at a lay audience.

Ancrene Wisse always contained within it different functions and the possibility of being used by different audiences, and herein lies the strength, durability and continuing interest of Ancrene Wisse. In this book, I study these different functions and audiences, tracing the development of Ancrene Wisse as a work of vernacular spirituality from the early thirteenth-century context in which it was originally written to its readership in the 
late Middle Ages. Ancrene Wisse was originally composed in the reforming atmosphere that prevailed in England in the second quarter of the thirteenth century; in order to explore this context, I start with an examination of the Fourth Lateran Council, which can be understood as the Church's response to a movement towards reform that was evident in the twelfth century. The foundation of the mendicant orders in the early thirteenth century was a manifestation of this movement, but it is the female religious movement that I study in some detail, in particular the beguines of the Low Countries and northern France. The religious context is a matter not only of actions and events, but of shifts in theology and spirituality. This book will examine some of these changes, in particular the development of eucharistic theology and the growth of an anchoritic spirituality that was moving away from the monastic roots of anchoritism and embracing new forms of lay piety, and show their relevance to the composition of Ancrene Wisse. Many of the devotions prescribed for the anchoresses in Ancrene Wisse are those that were gaining popularity among the devout laity during the high Middle Ages. The spirituality of Ancrene Wisse occupies a transitional position between monasticism and later lay piety; it is a spirituality that is both affective and incarnational.

Of great importance to an understanding of the construction of Ancrene Wisse is an understanding of the literature associated with these reform movements, that is, the Latin pastoralia of the twelfth and thirteenth centuries and the later vernacular pastoral literature that was indebted to it. I examine how the author of Ancrene Wisse used and adapted the rhetoric of pastoralia, and so became a forerunner of the vernacular pastoral literature that was to blossom in England in the late fourteenth century. In particular, Ancrene Wisse owes much to the rhetoric of preaching, and just as the anchoresses could be compared in their spirituality to the beguines on the Continent, so Ancrene Wisse can be compared to the sermons which were composed for the guidance of the beguines.

These are all areas that need to be explored fully to understand the construction of Ancrene Wisse as a vernacular, pastoral text in the early thirteenth century, and in the third part of this book I offer a close reading of Ancrene Wisse that gives an account of both its rhetoric and its spirituality, 
showing that both are firmly based in their historical and religious context. The spirituality of Ancrene Wisse is affective and contemplative, and a comparison with late medieval works, such as Walter Hilton's Scale of Perfection, enables us to establish Ancrene Wisse in the history of vernacular spirituality, which includes the writings of the Middle English Mystics. In conclusion, I argue that the textual history of Ancrene Wisse is relevant to our reading of the text; this work continued to influence devotional works for more than two centuries, and its place in Matthew Parker's library as the Reformation established a new Church in England argues that its dynamism and variability kept it alive and relevant.

\section{Notes}

1 'Ant ze, mine leoue sustren, habbeð moni dei icrauet on me efter riwle', The English Text of the Ancrene Riwle: Ancrene Wisse, edited from MS Corpus Christi College, Cambridge 402, ed. J. R. R. Tolkien, EETS 249 (London: Oxford University Press, 1962), fo. $1^{\text {a }} 11-12$. This version of Ancrene Wisse will be referred to as $A W$ Corpus Christi, with folio and line references; punctuation is modernized and abbreviations are expanded in accordance with that in Millett's forthcoming edition for the EETS, and the translations of Ancrene Wisse are by Bella Millett. I am very grateful to Bella Millett for permission to use her editions prior to their publication.

2 E. J. Dobson, The Origins of Ancrene Wisse (Oxford: Clarendon Press, 1976), p. 11.

3 Bella Millett uses Corpus Christi as the base for her edition for EETS (forthcoming), as does Robert Hasenfratz, Ancrene Wisse, TEAMS (Kalamazoo: Medieval Institute Publications, 2000). Millett is also preparing a translation based on the Corpus Christi MS, to be published by Exeter University Press; see also translations by Hugh White, Ancrene Wisse: Guide for Anchoresses (London: Penguin, 1993), and Anne Savage and Nicholas Watson, Anchoritic Spirituality: Ancrene Wisse and Associated Works (New York: Paulist Press, 1991).

4 ' 3 e, mine leoue sustren, beoð peo ancren pet ich iknowe pet habbeð lest neode to uroure azean peos temptaciuns, bute one of sicnesse; vor mid more eise ne mid more menke not ich none ancre pet habbe al pet hire neod is pene ze preo habbeð... 


\section{INTRODUCTION}

Euerich of ou haueð of one ureonde al pet hire is neod; ne perf pet meiden sechen nouðer bread ne suuel fur pene et his halle... Muche word is of ou, hu gentile wummen ze beod, vor godleic ant for ureoleic izirned of monie, ant sustren of one ueder ant of one moder, ine blostme of ower zuweðe uorheten alle worldes blissen any bicomen ancren.' The English Text of the Ancrene Riwle, edited from Cotton MS Nero A.xiv, ed. Mabel Day, on the basis of a transcript by J. A. Herbert, EETS 225 (London: Oxford University Press, 1952 (for 1946)), p. 85, 8-2; hereafter referred to as $A W$ Nero with page and line numbers. The Preface of the Nero version also contains a reference to the anchoresses' request for a rule: 'And ze mine leoue sustren habbeð mo-ni dai iremd on me efter riwle', $A W$ Nero, p. 1, 9-10.

5 'Twenti nuðe oðer ma', AW Corpus Christi, fo. 69a 14.

6 Dobson, Origins, pp. 252-3.

7 Ibid., pp. 260, 264.

8 Bella Millett, 'Mouvance and the medieval author: re-editing Ancrene Wisse', (ed.), in A. J. Minnis Late-Medieval Religious Texts and their Transmission (Cambridge: Brewer, 1993), p. 15. In this context, the author can be assumed to be male.

9 'Mine leoue sustren, pis fifte dale, pe is of schrift, limpeð to alle men iliche; for-pi ne wundri ze ow nawt pet Ich toward ow nomeliche nabbe nawt ispeken i pis dale. Habbeð pah to ower bihoue pis lutle leaste ende.' AW Corpus Christi, fo. 93 2-6.

10 ' 3 e pe of swucches nute nawt, ne purue ze nawt wundrin ow ne penchen hwet Ich meane, ah zeldeð graces Godd pet ze swuch uncleannesse nabbeð ifondet, ant habbeð reowðe of ham pe i swuch beoð ifallen.' Ibid., fo. $55^{\text {b }} 20-24$.

11 'Leste sum leorni mare uuel pen ha con', AW Pt. 4, Corpus Christi, fo. $55^{\text {b }} 11-12$; see also $A W$ Nero, p. 91 27; and The English Text of the Ancrene Riwle edited from BM Cotton MS Cleopatra C.vi, ed. E. J. Dobson, EETS 267 (London: Oxford University Press, 1972), fo. $87^{\mathrm{v}} 1-2$; hereafter referred to as $A W$ Cleopatra with folio and line numbers.

12 'Ich am an ancre; a nunne; a wif iweddet; a meiden; a wummon pet me lefde se wel; a wummon pe habbe ear ibeon ibearnd wið swuch ping and ahte pe betere forte beon iwarnet.' $A W$ Corpus Christi, fo. $86^{\text {b }} 12-15$.

13 Ibid., fo. 44 ${ }^{\mathrm{b}} 8-9$.

14 Yoko Wada, 'What is Ancrene Wisse?', in Yoko Wada (ed.), A Companion to Ancrene Wisse (Cambridge: Brewer, 2003), pp. 1-28 (pp. 7, 19), hereafter Companion.

15 Bella Millett, Annotated Bibliography, pp. 49-52; questions about this early dating are now being raised: Malcolm Parkes, 


\section{INTRODUCTION}

who dates MS Cleopatra to the early 1230s, thinks the Corpus Christi manuscript may have been copied as late as the 1270s or $1280 \mathrm{~s}$, and that it could be a palaeographically archaizing manuscript (personal communication with Millett).

16 E. J. Dobson, 'The date and composition of Ancrene Wisse', Proceedings of the British Academy, 52 (1966) (London: pub. for the British Academy by Oxford University Press, 1967), pp. 181-208 (p. 192).

17 Marion Gibbs and Jane Lang, Bishops and Reform 1215-1271, with Special Reference to the Lateran Council of 1215 (London: Oxford University Press, 1934), pp. 108-11.

18 'Vre Freres Prechurs ant ure Freres Meonurs', AW Corpus Christi, fo. $16^{\text {b }} 13$, and 'Freres Preachurs ant Meonurs', ibid., fo. $112^{\mathrm{b}}, 11-12$.

19 Dobson, 'Date and composition', p. 195.

20 Dobson, Origins.

21 Millett, 'Origins', p. 213.

22 Yoko Wada has added her voice to that of Bella Millett in support of Dominican authorship, 'Dominican authorship of Ancrene Wisse: the evidence of the Introduction', in Y. Wada (ed.), A Book of Ancrene Wisse (Suita, Osaka: Kansai University Press, 2002), pp. 95-107 (p. 107).

23 'Verseilunge of Sawter, redunge of Englisc oðer of Frensch', $A W$ Corpus Christi, fo. $11^{\text {a }} 22-3$.

24 Bella Millett, 'Women in no man's land: English recluses and the development of vernacular literature in the twelfth and thirteenth centuries', in Carol M. Meale (ed.), Women and Literature in Britain, 1150-1500 (Cambridge: Cambridge University Press, 1993; 2nd edn, 1996), pp. 86-103 (p. 94).

25 M. B. Parkes, 'The literacy of the laity', in David Daiches and Anthony Thorlby (eds), Literature and Western Civilization: The Medieval World (London: Aldus Books, 1973), pp. 555-77; and M. T. Clanchy, From Memory to Written Record: England 1066-1307 ([1979] Oxford: Blackwell, 1993), esp. 'Literate and illiterate', pp. 224-52.

26 'Hwa-se ne con peos fiue segge pe earste ...' and 'De ne con oper Uhtsong, oðer ne mei seggen ...', AW Corpus Christi, fo. $5^{\text {a }}$ $24-25 \&$ fo. $12^{\text {a }} 3$.

27 Bella Millett, 'Ancrene Wisse and the Book of Hours', in Denis Renevey and Christiania Whitehead (ed.), Writing Religious Women: Female Spiritual and Textual Practices in Late Medieval England, (Cardiff: University of Wales Press, 2000), pp. 21-40 (p. 22).

28 AW Corpus Christi, fo. $115^{\text {b }} 9$.

29 Ibid., fo. $116^{\mathrm{b}} 16-18$ 


\section{INTRODUCTION}

Millett, 'Mouvance', p. 12.

31 Barbara Newman, 'Flaws in the golden bowl: gender and spiritual formation in the twelfth century', Traditio, 45 (1989-90), 111-46; repr. in From Virile Woman to WomanChrist: Studies in Medieval Religion and Literature (Philadelphia: University of Pennsylvania Press, 1995, p. 21.

32 Alexandra Barratt, 'Small Latin? The post-Conquest learning of English religious women', in Siân Echard and Gernot R. Wieland (eds), Anglo-Latin and its Heritage: Essays in Honour of A. G. Rigg on his 64th Birthday, Publications of the Journal of Medieval Latin, 4 (Turnhout: Brepols, 2001), pp. 51-65 (p. 53).

33 Lesley Johnson and Jocelyn Wogan-Browne, 'National, world and women's history', in David Wallace (ed.), The Cambridge History of Medieval English Literature, (Cambridge: Cambridge University Press, 1999), pp. 92-121 (p. 111); hereafter referred to as CHMEL.

34 Janet Grayson, Structure and Imagery in Ancrene Wisse (Hanover, NH: University Press of New England, 1974).

35 Linda Georgianna, The Solitary Self: Individuality in the Ancrene Wisse (Cambridge: Harvard University Press, 1981), p. 3.

36 See Roger Dahood, 'The current state of Ancrene Wisse Group studies', Medieval English Studies Newsletter, 36 (1997), 6-14; and Cate Gunn, 'Ancrene Wisse: a modern lay person's guide to a medieval religious text', Magistra, 8 (2002), 3-25 (10-11).

37 Anne Savage, 'The solitary heroine: aspects of meditation and mysticism in Ancrene Wisse, the Katherine Group, and the Wooing Group', in William F. Pollard and Robert Boenig (eds), Mysticism and Spirituality in Medieval England, (Cambridge: Brewer, 1997), pp. 63-83 (p. 64).

38 Liz Herbert McAvoy, Rhetoric of the Anchorhold: Place, Space and Body within the Disclosures of Enclosure (ed.), (Cardiff: University of Wales Press, forthcoming).

39 E.g. Catherine Innes-Parker, 'The legacy of Ancrene Wisse: translations, adaptations, influences and audience, with special attention to women readers', pp. 145-73, Christina Von Nolcken, 'The Recluse and its readers: some observations on a Lollard interpolated version of Ancrene Wisse', pp. 175-96, and Nicholas Watson, 'Ancrene Wisse, religious reform and the late Middle Ages', pp. 197-226, in Wada (ed.), Companion.

40 Barbara Newman, 'Flaws in the golden bowl' p. 22.

41 Bella Millett quotes the Summa de Penitentia of Odo of Cheriton: 'Sed Iudit, que interpretatur confessio ...' notes to her forthcoming edition of Ancrene Wisse, quoting MS Peterhouse 109, fo. 237r ; and in Thomas of Chobham's Summa 


\section{INTRODUCTION}

de commendatione virtutum et extirpatione vitiorum we find: 'Iudith interpretatur confessio ...', ed. by F. Morenzoni, CCCM vol. 82B (Turnhout: Brepols, 1997), pp. 14-15; Aelred, Sermo 45, ed. by G. Raciti, CCCM vol. 2A (Turnhout Brepols, 1989), p. 358; Peter Damian, De perfectione monachorum PL vol. 145, col. 308B.

42 'Iosue, Iephte, Gedeon, Samson, Iudith quoque, quamquam femina, gloriose in diebus suis triumpharunt de hostibus', Bernard of Clairvaux, Sermones in Cantica, Sermo 12, PL 183, 836B-C.

43 Newman, 'Flaws in the golden bowl', pp. 31, 21.

44 Caroline Walker Bynum, Fragmentation and Redemption: Essays on Gender and the Human Body in Medieval Religion (New York: Zone Books, 1992), p. 218.

45 'Vobis, fraters, alia quam aliis de saeculo, aut certe aliter dicenda sunt', Bernard of Clairvaux, Sermo 1, 'Sermones super Cantica Canticorum', in S. Bernardi Opera, ed. J. Leclercq et al., vol. 1 (Rome: Editiones Cistercienses, 1957), p. 3.

46 'Et medicamentum quod hunc morbum imminuit, alteri uires iungit; et panis qui uitam fortium roborat, paruulorum necat', Gregory the Great [Grégoire le Grand], Règle Pastorale, Sources Chrétienne, 382 (Paris: Éditions du Cerf, 1992), p. 258.

47 'Ant alle ich habe tobroken ham ow, mine leoue sustren, as me deð to children pe mahten wið unbroke bread deien on hunger. Ah me is, pet wite ze, moni crome edfallen; secheð ham ant gederið, for ha beoð sawle food', $A W$ Corpus Christi, fo. $92^{\mathrm{b}}$ 23-6. 


\section{Part I}

The religious context 



\section{1 \\ The Fourth Lateran Council}

The religious and intellectual context in which Ancrene Wisse was composed is also the context in which the Fourth Lateran Council was convened; many of the themes of Ancrene Wisse - the religious status of the anchoresses, the importance of confession, the nature of the Eucharist, as well as the overall pastoral concern of the work - are those of a post-Lateran Four world, and it is in this context that Ancrene Wisse must be read. We need, therefore, to understand something about the Council, why it was convened at that particular time, what its decrees say about the relationship between the Church and the laity, and the influence it had on the development of pastoral literature. This Council is often considered a watershed in the history of the institutional church, marking a shift in the relationship between the Church and the laity; the Fourth Lateran Council, however, needs to be seen not only as instigating change but also as responding to the changes that were already taking place. Some of the decrees of the Councils, such as the prohibiting of new orders, can be seen as damage limitation, while others are recognizing demands made on the Church by a changing society - a society that was better educated, more mobile and beginning to require more of the Church and its priests.

The first Lateran Council was held in Rome in 1123; the fourth, and arguably the most important - it is certainly the most famous - in 1215. The first four Lateran Councils (the fifth was held in the early sixteenth century and need not concern us) were all called in order to establish and proclaim the unity and authority of the Church: the second (1139) and third (1179) were held at the conclusion of schisms. At the heart of the Councils, though, was a concern with the reform initiated by Pope Gregory VII in the eleventh century. 
Hildebrand, who became Gregory VII on his election to the papacy in 1073, is well known for his clash with the Holy Roman Emperor, Henry IV, over the right of the emperor to appoint bishops; investiture of bishops was still an issue in both the first and second Councils. Much of the reform known as 'Gregorian' was to do with the authority of the Church, but alongside the promotion of authority was an attempt to tackle corrupt practices in the Church, such as simony and the marriage of priests: arguably, the Church needed to be seen to be righteous in order for its authority to be credible. Through the reform programme of the Lateran Councils, the Church sought to establish both the authority and the alterity of the clergy; Caroline Walker Bynum has suggested that 'It was the Gregorian Reform movement of the mid-eleventh century that created a church headed by the clergy and began the process of locating the supernatural power most centrally in the Eucharist, which the priest controlled'.1

Pope Innocent III declared in a letter of 1213, in which he was calling for the convening of the Council, that one of the things he most desired in his heart was the 'reformation of the universal church'. ${ }^{2}$ The Fourth Lateran Council advocated reform throughout the Church, both clerical and monastic; but there was also a movement for reform outside the Established Church.

Religious reform needs to be understood within the wider social context; the relationship between social and religious change should not be oversimplified, but some connections between the changes in European society and the ways in which piety was expressed and religious vocations pursued can be suggested. Western Europe underwent an 'economic miracle' during the course of the twelfth century, and a new, wealthy bourgeois class arose in the rapidly growing towns and cities of northern Italy, Flanders and the Rhineland; C. H. Lawrence associates these shifts in society with a new political - and religious - consciousness:

The literate laity who formed the upper strata of the new urban society, dissatisfied with the passive role of a spiritual proletariat assigned them by traditional ecclesiology and aware of the educational and moral shortcomings of the secular clergy, were a natural forcing-ground both for orthodox criticism of the Church and for radical dissent. ${ }^{3}$ 
The urban nature of thirteenth-century society, in England at least, should not be overemphasized, since 'Medieval England was never intensively urbanized', and the only town in England in the thirteenth century of the size of the towns in Flanders, northern France and Italy was London. ${ }^{4}$ Nevertheless, society was changing, and as people were becoming more prosperous, and as the economy became dependent as much on trade as on basic agriculture, it became necessary for merchants and traders to have some functional literacy. Increasing trade led to the exchange of ideas, and growing wealth meant people with functional literacy would have the time - and often inclination - to extend their reading to pleasure and personal education. On the Continent, the Waldensian movement, which is discussed below, could be considered an example of the outcome of such social change; but it is in England that we find evidence of pastoral reform and a programme of teaching and preaching encouraged by bishops and other members of the ecclesiastical hierarchy.

Within the Church, reform had largely taken the form of new monastic orders, most notably the Cistercian and Carthusian orders, which were founded in the last years of the eleventh century, and new orders of Augustinian canons, including the Premonstratensians and Arrouaisians, which were founded during the twelfth century. Towards the end of the twelfth century, however, there was an increasing number of people who would not have traditionally entered a monastery but who now wanted to pursue a religious vocation, in response to the growth in popular piety; they provided the momentum for change and renewal outside the traditional institutions of the Church. Both the establishment of the mendicant orders at the beginning of the thirteenth century and the popularity of heretical movements, from the Cathars to the Waldensians, can be seen as manifestations of the same motivation for change among an increasingly articulate and literate middle class.

The concept of the apostolic life had been interpreted as the common life, to be pursued within a monastery in imitation of the early Christian communities; but another interpretation, based on the order of Jesus to the Apostles to go out into the world and preach the gospel to everyone (Mark 16: 15) began 
to predominate during the course of the twelfth century. ${ }^{5}$ The Waldensians, followers of Waldes, a wealthy merchant from Lyons, turned to the Gospels for validation of their mission. Waldes did not want to separate from the Church and sought advice 'from priests and theologians of the Roman church'; nevertheless, by reading the Gospels in translation and seeking to follow a life in keeping with Gospel teaching as they understood it, Waldes and his followers pursued a way of life that was similar to that of heretics - committed to "voluntary poverty and apostolic itinerant preaching. ${ }^{6}$ Early documents of the Waldensians insist on the orthodoxy of their beliefs, ${ }^{7}$ and, indeed, Waldes approached the curia of the Church in the hope that he could gain ecclesiastical approval for preaching.

There was, however, an increasing fear of the threat of heresy to the authority of the Church, and a council met at Verona in 1184, under Pope Lucius III, to address these issues. At the top of the agenda was unauthorized preaching, and a number of groups, including the Waldensians, known as the 'Poor Men of Lyons', and the Humiliati were condemned as heretics. ${ }^{8}$ Innocent III, pope from 1198, had some sympathy with those who interpreted the apostolic mission as one of poverty and preaching, on the model of the Apostles - he was to become a champion of the Franciscans - and attempted a compromise which would allow some itinerant preaching. ${ }^{9}$ The Waldensians split, but some, under the name 'Poor Catholics', remained orthodox, under the leadership of Durandus of Huesca and Bernard Prim. ${ }^{10}$ Colin Morris has commented: 'Movements with clearly unorthodox beliefs were condemned along with others which merely practised unauthorized preaching, and as a result enthusiasts of the apostolic life were separated from the church'.11 The authorities of the medieval Church might have questioned that 'merely': it was because of their activities - and the influence they could thereby have on ordinary lay people rather than any avowed belief-system that the Waldensians were viewed as a threat by the hierarchy of the Church.

The first decree of the Fourth Lateran Council, 'De fide catholica', is a statement of faith from which all else follows either as a defence of that faith, to the extent of defining heterodoxy and condemning it as heresy, or as a promotion of 
that faith, through the establishment of a programme of pastoral care. The decrees of the Fourth Lateran Council were responding to the movement for reform, but the Council also set the tone, and the limits, for the developments that were to take place in the thirteenth century - especially the rise of the mendicant orders, the importance of preaching beyond the cloister, and the response to religious women. Greater awareness of the pastoral needs of people and the duties of the Church preceded the Fourth Lateran Council; the Council was not so much innovative as affirming the awareness of these needs.

The Fourth Lateran Council defined heresy and sought to construct an effective and systematic defence against it, in a way that had not been attempted before. The decree 'De haeriticis', following the condemnation at the Council of Verona, stated that no one should claim the authority to preach for himself, unless his authority had been acknowledged by the apostolic see or the bishop of that place. ${ }^{12}$ Alongside this concern with threats to the Church, however, was an awareness of the positive duties of the Church towards the people in its care. The bishops were responsible for the pastoral care of the laity, and the Fourth Lateran Council insisted that this duty be taken seriously; the tenth decree, 'On appointing preachers', insisted on the importance of preaching to the people, since man lives not by bread alone but 'by every word that proceeds out of the mouth of God' (Matthew 4: 4), and made allowances for bishops to appoint 'suitable men' to aid them in the 'duty of sacred preaching'. Bishops were also to appoint, in cathedrals and conventual churches, suitable men to help in hearing confessions and enjoining penances and in other matters which are conducive to the salvation of souls'. ${ }^{13}$ There is no mention of parish priests, but it is clear that clerics in lower orders than prelates were expected to be better educated. The Fourth Lateran Council did acknowledge the problem, and the desire to help the parish clergy in their pastoral duties, now defined as primarily consisting of preaching and penance, led to an increase in the production of pastoral literature; the composition of Ancrene Wisse within the context of the production of pastoral literature will be discussed at greater length later. 
The requirement for education on faith and morals was not just an edict from above; Robert Courson, writing in 1207, had commented on the demands made by those responsible for education in faith and morals for more help: they were like toothless children fed only pap and were banging on the doors of theology for the solid food of disputation. Courson was using an image which he attributed to Gregory, and which is found also in the Chanter's Verbum Abbreviatum, that 'nothing is fully understood unless it is broken with the teeth of disputation'. ${ }^{14}$ The need for education was not immediately met throughout Europe, however; in one of his 'sermones vulgares' addressed to boys and youths, and dating from the 1230 s, James of Vitry used similar imagery to that of Robert Courson:

'The little ones have asked for bread, and there was none to break it unto them.' With these words, in the fourth chapter of his Lamentations, Jeremiah deplored the lack of learning and instruction which children and young people - who are easily suited to learning - especially need, just as soft and pliable wax easily receives the impression of a seal. But there are few if any who will preach to them and break unto them the bread of learning. Thus, just as a body that lacks material bread fails, so too do the souls of little children grow weak and wither. ${ }^{15}$

The image of pupils as wax in which the teacher imprinted his seal was a common one; that of spiritual teaching as food that needs to be broken up is one we will see often in the course of this discussion.

The pastoral care of the laity by the Church was one of the most important issues dealt with by the Fourth Lateran Council. The Church struggled to keep the laity under control and to define their role 'within the divine economy' as the relationship between clergy and laity shifted. ${ }^{16}$ The Council insisted on annual communion for all people of the age of reason; ${ }^{17}$ this was not a new requirement, but the Fourth Lateran Council can be seen as another attempt to insist on this minimum - and an attempt that seems to have succeeded. It was only a minimum, and not one everyone found satisfactory; James of Vitry castigated those who only went to church when they were obliged to for their annual 
communion, calling them 'rudes et bestiales'. ${ }^{18}$ Annual communion was necessarily preceded by confession and penance, and there was a renewed insistence that all parishioners should confess privately to their own parish priests, 'proprio sacerdoti' ${ }^{19}$ Robert Courson commented on the necessity of seeking special permission if a priest other than one's own were to impose penance; ${ }^{20}$ Courson was a teacher in Paris and played an important role in the reforms which culminated in the Fourth Lateran Council. The nature of confession and penance had been changing significantly over the previous century, and the parish priest's role as confessor developed in significance and importance during the course of the thirteenth century. In the pastoral literature dealing with confession produced after the Fourth Lateran Council, we see a new emphasis on the circumstances of the sin; however, the idea that intention is the most important element in sin goes back at least to the twelfth century and was discussed by Peter Abelard. According to Abelard, the man who looks in such a way as to fall into consent to lust has already committed the sin of adultery, but someone who is tricked into sleeping with someone he believes to be his wife is not guilty of sin: it is the consent to lust that is sinful. ${ }^{21}$ Abelard commented: 'Sin lies neither in being tempted to do nor in doing what is wrong; it lies between these two moments, in consenting to the initial temptation. 22

Christina of Markyate, an anchoress in the twelfth century, is recorded as being fearful of what she should say at her consecration as a virgin since, although she 'was not conscious of having fallen either in deed or in desire, she was chary of asserting that she had escaped unscathed'. Christina was aware of 'the thoughts and stings of the flesh with which she had been troubled'. ${ }^{23}$ This fear may have been due to the debate on intention going on in the schools $;{ }^{24}$ certainly, there is a concern with the mental state that accompanied sins, and whether one could be responsible for involuntary bodily sensations. The author of Ancrene Wisse believed that all possible action should be taken to avoid any situation that could lead, however unwittingly, to sin. The anchoress should not allow herself to be seen, unless she should provide an occasion for men to fall into sin: she would then be someone 
who uncovered a pit into which an animal fell: 'The pit is her fair complexion, her white neck, her roving eyes, her hand, if she holds it out where he can see it. ${ }^{25}$

This emphasis on intention - on the mental act rather than the physical activity - meant that the penitent had to accept accountability for actions known to be sinful, and confession had to cover, not the action itself, so much as the intention and consent. Interior penitence was what counted: Leonard Boyle points out that 'the act of confessing becomes more personal, more aware of self', as genuine contrition, rather than outward acts of penance, was required; ${ }^{26}$ while Colin Morris detects a shift towards personal confession and the importance of the individual conscience from the twelfth century onwards. ${ }^{27}$ In a sermon on the conscience, Robert of Sorbonne praised beguines because they frequently made their confession; this enabled them to know themselves: 'Many know many things and do not know themselves. They seek God in exterior things and forget about their own inner selves.' 28 The author of Ancrene Wisse also places emphasis on the role of consent in falling prey to temptation and committing mortal sin, and the concern with confession and penance, which are marked features of Ancrene Wisse, is typical of pastoral literature of the thirteenth century designed to aid priests in the execution of their pastoral duties.

The anchoresses for whom Ancrene Wisse was written were seeking to follow a religious vocation outside the traditional institutions of the Church, and so would have been affected by the thirteenth decree of the Fourth Lateran Council, which prohibited the invention of new orders, 'lest too much diversity of religious forms should bring about troublesome confusion in the church of God'. Anyone wanting to enter a religious house 'should accept the rules and practices of an approved order'. ${ }^{29}$ This was to stem the growth of unauthorized - and potentially heretical - religious orders, and may explain the anxiety the anchoresses seem to have felt over their status. The author refers to their concern and advises them that, if anyone ask them, they should reply that they belong to the order of $\mathrm{St}$ James, referring to the epistle of St James in which he defines religion as, 'to visit and help widows and fatherless children, and keep oneself pure and unspotted from the world' ${ }^{30}$ It is 
the second part of this - keeping oneself pure and unspotted from the world - that is to apply to the anchoresses. In the Latin, the word religio is used, which is given in the Middle English as religiun. Given the context, it is clear that what is intended here, by the author of Ancrene Wisse, if not by St James, is a definition of the religious life; the author of Ancrene Wisse sees in this short passage a distinction between active and contemplative forms of religious life. It should be remembered that the modern use of the term religion as a system, or systems, of faith is a modern concept and, although the way the term religio was used was shifting, it was not used in this way in the Middle Ages: religion tended, at this period, to mean specifically the religious life. ${ }^{31}$ The anchoresses are identified with the religious who are withdrawn from the world, and, indeed, they should keep themselves pure and unspotted 'ouer oper religiuse'. ${ }^{32}$ Ancrene Wisse insists that 'religion' is not a matter of clothing, or even the vows taken; the implication of much of Ancrene Wisse is that, as anchoresses enduring solitude and strict enclosure, they partake of a spiritual life that is superior, being harsher, to that of nuns. For them, the anchorhold was an alternative to the nunnery, but they did not enjoy the security and authority of a recognized religious order.

The author of Ancrene Wisse was not alone in suggesting that the religious life may be other than membership of an established religious order. Henry of Susa, for example, distinguished between a regular religious and a religious in a broader sense: 'Someone who lives in a holy and religious way in his own house, although not professed, is also called a religious in a broad sense. 33 A regular meant one who followed a rule which was normally understood to mean a monastic rule; James of Vitry claimed that all the faithful can be called regulars, insofar as they follow the rules of their various callings: they each work together according to their talents, as a body is comprised of different parts working under one head, and living under the one supreme abbot, who is Christ. ${ }^{34}$ Similarly, the expanded group of anchoresses who are referred to in the revised version of Ancrene Wisse found in the Corpus Christi manuscript lived according to a rule, as though in a convent over which Jesus is the high prior. ${ }^{35}$ 
It is not entirely clear what, at this time, constituted a religious order. A book on 'The different orders in the Church', the Libellus de diversis ordinibus et professionibus qui sunt in cecclesia, was written in the mid twelfth century, probably in north-eastern France or the Low Countries. ${ }^{36}$ It argues that a variety of religious orders is necessary to satisfy different men responding to a religious calling; the Church, however, became anxious to impose order on religious houses, and the twelfth decree of the Fourth Lateran Council, De communibus capitulis monachorum, states that those orders which do not have a general chapter should hold chapter meetings on the pattern of the Cistercians. ${ }^{37}$ While movements such as the Waldensians and Humiliati were proscribed, the new mendicant orders, born of the same religious impulse, were able to gain approval. Francis obtained approval for his order from Innocent III prior to the Fourth Lateran Council, while the Order of Preachers, known as Dominicans, adopted the rule of Augustine, Dominic himself being an Augustinian canon.

The preaching mission itself was started as much by individuals such as Francis and Dominic (as well as Waldes) as by the institutions of the Church. The Dominicans were initially established in response to the Cathar heresy, also called Albigensian, after the town Albi, in south-west France, which was a centre of the heresy. The second Master of the Order, Jordan of Saxony, wrote an account of the beginning of the Order of Preachers: Dominic had been travelling to the Danish Marches with Diego, the Bishop of Osma, on a diplomatic mission; on their way they had argued with a heretic in Toulouse, 'and at last brought him back to the faith'. While on their return they visited Citeaux and were impressed by 'the excellence of their religious observance'; however, when they met with a Cistercian delegation which was commissioned to preach the faith against the Albigensian heretics they were dismayed to note the contrast between the heretics' 'feigned example of holiness' and 'the missionaries' enormous supply of provisions and horses and clothing'. Diego insisted on converting through example rather than talking: 'Use a nail to drive out a nail. Chase off their feigned holiness with true religious life. The imposing appearance of 
the false apostles can only be shown up for what it is by manifest humility. 38

If the way of life of the Waldensians had been dangerously close to that of heretics, Diego and his sub-prior Dominic, who continued his work, deliberately copied the heretic model of poverty and preaching in order to convert heretics. Conversion of heretics was only one aspect of Dominic's mission: he also instructed the faithful in the diocese of Toulouse, with the support of the bishop, Fulk. Dominic saw himself and his followers as assisting bishops - those responsible for preaching and teaching - and it was as an Order of Preachers that his followers were established.

These two mendicant orders that arose in the early thirteenth century can be seen as a 'providential response to a spiritual crisis', and as such were welcomed by Innocent III;39 but they also presented a challenge to the hierarchical authority of the Church. The Dominicans and the Franciscans, the 'Freres Prechurs' and 'Freres Meonurs', recommended as confessors in Ancrene Wisse, ${ }^{40}$ were a major force in the changing piety of the Middle Ages. They represented a significant shift in focus and purpose for those pursuing a religious life, away from monastic spirituality. Instead of attempting to achieve salvation through personal perfection, to be found by withdrawing from the world as monks had done, the friars saw it as their duty to preach to the people, to hear their confessions and to bring them to repentance. James of Vitry, who was deeply involved in the education of preachers, saw the Franciscans and Dominicans as 'part of the answer to the thirteenth-century crisis in pastoral care'. ${ }^{41}$ The use of the services of friars, was recommended in English diocesan statues, and Robert Grosseteste begged for the help of friars with the 'heavy burden of pastoral care', although this opened up the possibility of conflict with parochial clergy. ${ }^{42}$ Religion was moving out of the cloister and into the marketplace. 


\section{2 \\ Eucharistic theology}

The statement of faith that constituted the first decree of the Fourth Lateran Council included the declaration that the bread and wine in the Eucharist were changed into the body and blood of Christ:

His body and blood are truly contained in the sacrament of the altar under the forms of bread and wine, the bread and wine having been changed in substance, by God's power, into his body and blood, so that in order to achieve this mystery of unity we receive from God what he received from us. ${ }^{1}$

At the heart of the worship of the Catholic Church in the high Middle Ages was the Eucharist, and central to the faith of that Church in the high Middle Ages was a belief in transubstantiation.

The term transubstantio and its verbal equivalents are first found in the twelfth century, ${ }^{2}$ but the concept of a change in substance of the bread and wine into the flesh and blood of Christ is much older: the potential conflict between varying understandings of the presence of Christ in the consecrated Host had come to a head with the Berengarian controversy. In 1059, Berengar of Tours was condemned for his views, which had stressed the spiritual presence of Christ in the Host, and was required to assent to the statement that after the consecration of the bread and wine at the altar it is the flesh of Christ that is broken by the hands of the priest and chewed by his teeth'. ${ }^{3}$ This statement led to a crystallisation of ideas that had previously been vague and the dogma of Christ's bodily presence in the host eventually passed into canon law. ${ }^{4}$ The Fourth Lateran Council stated as a matter of faith that the bread and wine were transformed into the blood and wine of 
Christ without defining how this transformation took place. Philosophical and theological discussions on the nature of the transformation continued over the next three centuries; it was Aquinas' definition of transubstantiation, based on Aristotelian notions of substance and accident, that was authorized by the Council of Trent in 1551. Henry Bettenson states the complicated situation in the Middle Ages with clarity:

The term transubstantiation seems to have been adopted in the twelfth century; but it is impossible to say at what time it came to have a technical meaning, that is, to convey more than the assertion that the elements after consecration are 'really' the body and blood. So that when in 1215 the 4th Lateran Council decreed that 'the body and blood are truly contained in the sacrament of the altar under the species of bread and wine; the bread being transubstantiated into the body, and the wine into the blood by the power of God ...', it is impossible to assert with confidence that this statement anticipates the authorization by the Council of Trent of the kind of doctrine elaborated by S. Thomas. ${ }^{5}$

The philosophical niceties of eucharistic transformation may have been of little interest to the majority of Christians, but as the doctrine of transubstantiation was formulated by theologians, popular devotion to the real presence of Christ and the sacrament of the Eucharist grew. Central to the daily devotions prescribed in Ancrene Wisse was the Eucharist, and the devotional practice most familiar to lay people at the same time would have been attendance at Mass. Even if the congregation did not take communion regularly, being present at Mass was a highly significant element of the religious life of any community. The sacrament of the Mass was understood to be a re-enactment of the passion and sacrifice of Jesus Christ, as the words used recalled the Last Supper; those who received the Eucharist were partaking in his death, and so in his resurrection. Eamon Duffy points out that this 'implied an enormously high doctrine of priesthood', ${ }^{6}$ a consequence expressed by Francis of Assisi: 'How holy, and virtuous, and worthy should not a priest be; he touches Christ with his own hands ... A priest receives him into his heart and mouth and offers him to others to be received."7 
The Synod of Paris at the end of the twelfth century commanded that priests keep the Host concealed 'until they have said the words Hoc est corpus meum [This is my body] and then they are to raise it aloft so that it can be seen by all'. ${ }^{8}$ This meant that the Host would not be seen, and so could not be worshipped, before the consecration had transformed the bread and wine into the flesh and blood of Christ; in the early thirteenth century the fear was expressed that 'a creature be adored instead of the creator'. ${ }^{9}$ After the consecration, the Host could be raised and the presence of God gazed at and adored: ${ }^{10}$ most lay people may not have taken communion more than once a year, but whenever they attended Mass they believed themselves to be in the real presence of God. In Ancrene Wisse, it is God's body, 'Godes licome',11 that is raised, suggesting that the consecration had already taken place: it was God's body, not a piece of bread, that was raised.

The anchoresses are also advised of prayers to say during Mass, 'hwen pe preost heued up Godes licome'; ${ }^{12}$ the first prayer is one of praise as well as a statement of belief in the Incarnation: 'Behold the world's salvation, the Father's word, true sacrifice, Flesh full of life, complete Deity and true man.' 13 C. H. Talbot has identified this prayer with an invocation recommended for use by the congregation at the small elevation, that is, when the priest lifts the Host in order to consecrate it; this would be in keeping with the use of the prayer here. ${ }^{14}$ Millett, however, suggests a closer match can be found in a Latin elegy on the death of Maurice of Sully. The anchoresses are to stand for this prayer, and then kneel to deliver salutations; their participation is not only cerebral, but has a high level of sensory involvement. The one moment of ecstasy in Ancrene Wisse occurs during the Eucharist, and will be examined in detail later. Among the laity, eucharistic piety was an affective and emotional response to the belief in the presence of God in the consecrated Host; the people were sensually involved with the ceremony of the elevation: they could see the elevation, hear the ringing of the sanctus bell and smell the incense. ${ }^{15}$

This emotional involvement was taken to an extreme among some Continental religious women, for whom eucharistic devotion became associated with bridal mysticism 
and the language of consumption. James of Vitry used the language of the Song of Songs when writing of the eucharistic piety of religious women in the diocese of Liège in the early thirteenth century: 'Some of them ran with such desire after the fragrance of such a great sacrament that in no way could they endure to be deprived of it. ${ }^{16}$ As their only desire was for their heavenly bridegroom, ${ }^{17}$ there is a clear connection between receiving communion and receiving Christ as bridegroom. Eucharistic devotion was an important feature in the life of the nuns of Helfta; the combination of bridal imagery and eucharistic devotion is found in the work of Gertrude of Helfta in the later thirteenth century, including The Herald of Divine Love. Mechthild of Magdeburg, who had been a beguine in Magdeburg before joining the convent at Helfta as an older woman, received visions, recounted in Flowing Light of the Divinity, which suggest an erotic relationship between the soul and God.

Both Gertrude and Mechthild associated the language of love with that of food. In The Herald of Divine Love, Christ appears during Mass as a lover to prepare Gertrude for the heavenly banquet which was holy communion; ${ }^{18}$ Mechthild of Magdeburg used the language of consumption with reference to Christ as bridegroom: 'The Bride has become intoxicated in the contemplation of the noble countenance... The more His desire grows, the greater their wedding becomes ... The more painfully they part, the more He gives her. The more she consumes, the more she has. ${ }^{19}$ Nevertheless, Mechthild approached the altar with a reverence and awe amounting to fear; she chastized her fellow beguines for taking communion 'out of blind habit': 'Now I, who am the least amongst you, must feel shame, sweat and tremble. One feast day I was so overwhelmed that I did not dare receive Him, for in His presence I was ashamed of my greatest virtue. $^{20}$ After confession, however, she believes she can approach the altar with hope: 'Now I shall go to God's table with joy and I shall receive that same bloodied Lamb that wanted to hang on the holy cross with His five holy wounds, bloody and untended. ${ }^{21}$

The association between the sacrament of the altar and the death of Christ on the cross allows this dwelling on the bloody 
fleshliness of the sacrifice; the bloody lamb was also present in a vision Mechthild had of John the Baptist celebrating Mass, when the wafers were transformed into a bleeding lamb hanging from a red cross. The poor servant girl observing this approaches the altar,

Then St John took the white lamb with its red wounds and placed it in her mouth between her jaws. Then the pure lamb settled itself on its own image in her stable and sucked at her heart with its sweet mouth. The more it suckled, the more she gave it. ${ }^{22}$

The blood of Christ is one of a nexus of images revolving around the idea of the sacrifice of Christ that redeemed humanity and was re-enacted in the Eucharist. Miraculous Hosts which appeared to change into bloody flesh became the objects of pilgrimage, and the body and blood of Christ became the focus of a new feast of devotion, Corpus Christi. The instigator of this feast, and main campaigner for it, was a religious woman from Liège, Juliana of Cornillon. Juliana was brought up from childhood in the religious house of Cornillon, which had been founded by citizens of Liège. Although the house had a practical mission, caring for lepers, Juliana pursued a life of devotion. During the celebration of the Eucharist, she had a vision of a full moon with a small piece missing, presumably inspired by the priest holding up the circular Host with his thumb and index finger. For her, the incomplete Host was a symbol of the imperfect Church. Christ revealed to her that he wanted an annual feast in celebration of the institution of the Sacrament of the Body and Blood. ${ }^{23}$ Juliana was not alone in her dedication and devotion to the Eucharist - it was a strong element of the spirituality of the beguines and other religious women, especially in the area around Liège. Caroline Walker Bynum suggests that it was through the Eucharist that such women were able to encounter the humanity of Christ: 'For thirteenth-century women this humanity was, above all, Christ's physicality, his corporality, his being-in-the-body-ness; Christ's humanity was Christ's body and blood.'24

Devotion to the Eucharist was part of the Christ-centred spirituality of these religious women; those inspired by Mary 
of Oignies were 'fervent devotees' of the holy sacrament. ${ }^{25}$ According to James of Vitry, Mary of Oignies 'took up the cross by chastising her body through abstinence and imitated Christ by casting herself down through humility'. ${ }^{26}$ This could also be read as a description of the life of the anchoresses, who, through their lives of humility and penance, were to share the pain and shame suffered by Christ on the cross. ${ }^{27}$ Bernard of Clairvaux commented on the importance of an emotional response to the incarnation and passion of Christ: 'Consideration of the incarnation of Christ and His entire existence in the flesh and most greatly of the passion most powerfully promotes this affective love of the heart. ${ }^{28}$

The ecstasies some women experienced during the Eucharist were not always considered a sign of grace, however; Ernest McDowell, writing about religious women in the twelfth and thirteenth centuries, comments, 'Since the Eucharist was often accompanied by ecstatic experiences, the chapter of Cîteaux had to forbid communion to those who could not retain their senses during the ceremony. ${ }^{29}$ Albert the Great also 'opposed daily communion for women because of their "levity", , but where the reception of communion was limited, the very infrequency of communion and the high expectations associated with it could lead to a heightened emotional state and a willingness to succumb to ecstasy. ${ }^{30}$ While hagiographies of religious women emphasized their holiness, seeing extreme responses to communion as a sign of such holiness, sermons and books of advice, such as Ancrene Wisse, were more likely to advocate moderation. 


\section{3 \\ The female religious movement: anchorites and beguines}

The text of Ancrene Wisse can be read as part of the fabric of the religious movement on the Continent in the twelfth and thirteenth centuries; in particular, its spiritual patterning bears comparison with the manifestations of female piety in the beguine movement of northern Europe. The similarities in spiritual expression make a comparison between Ancrene Wisse and the writings about and for beguines useful: the incarnational spirituality that is at the heart of Ancrene Wisse is also important in the literature of the thirteenth-century beguines and other religious women of this period. In Ancrene Wisse, there is none of the extreme emotionalism found in the writings of Mechthild of Magdeburg or Gertrude of Helfta, or in the vita of Mary of Oignies; but it should be remembered that while Mechthild and Gertrude were writing accounts of their own visionary experiences and the vita of Mary of Oignies is hagiographical, Ancrene Wisse was written as a guidebook for women. If we take into account the differences due to genre between Ancrene Wisse and the visionary writings or hagiographical accounts of the holy women on the Continent, the similarities in the spirituality of beguines and anchoresses become more apparent. We also need to consider the institutional aspects of beguine and anchoritic lives, including their daily devotions and practices.

Similarities in the daily lives and devotions of anchoresses and beguines are present, at least in part, because of similarities in the reasons why women chose ways of pursuing their religious vocations outside the traditional boundary of the convent. Beguines and anchoresses were seeking a religious life that was relevant to them. In the later Middle 
Ages, women were less likely to seek power as abbesses or play quasi-clerical roles, but they were seeking a peculiarly female spirituality, one that involved renunciation of wealth and marriage and saw virginity as a positive value. ${ }^{1}$ All the reforms in monasticism between the eleventh and thirteenth centuries had been 'designed to accommodate the spiritual aspirations of men'. ${ }^{2}$ The established Benedictine convents of nuns were almost exclusively aristocratic, which reduced the opportunities for women such as those for whom Ancrene Wisse were written, and who came from the gentry class.

The story of the women's religious movement is not a simple one, nor, indeed, is it the story of a single movement: temptations to present a single narrative must be resisted in favour of considering individual cases. Women's ability to follow a religious vocation was to a large extent at the mercy of male patrons, and vacillation between acceptance and rejection, enthusiasm and caution, is typical of male response to women's desire to enter the religious life. Women were often seen as a distraction from, if not a threat to, the orderliness of the religious life, yet there were always some individual men prepared to champion their cause and establish houses for them. The apparent misogynistic attitudes of church leaders need to be treated with some caution, and within historical context. Caroline Walker Bynum quotes the 'notorious opinion' of Conrad of Mechtal that 'the wickedness of women is greater than all other wickedness of the world', while noting that it 'may be spurious'; ${ }^{3}$ and the often-quoted question of Bernard of Clairvaux, 'To be always in a woman's company without having carnal knowledge of her, is this not a greater miracle than raising the dead?', also needs to be read in context: this was part of a tirade against the 'new heretics' from Toulouse, who claimed to be virtuous and to be able to be with women without submitting to desire. Bernard is asking why this claim, or any other, should be believed: 'Take away the cause of scandal, and prove the truth of your boast that you are a follower of the Gospel.' ${ }^{4}$

Other church leaders appear less eager to condemn women: James of Vitry played a vital supporting role in the birth of the beguines, taking the opportunity of his consecration as Bishop of Acre by the new Pope, Honorius III, to plead the cause of 
religious women to the curia in 1216, and gaining permission for them to live in communities. ${ }^{5}$ James of Vitry had spent many years as an Augustinian canon acting as the confessor of Mary of Oignies, who was at the centre of the new religious movement in Belgium and considered to be a precursor of the beguine way of life; after her death in 1213, he wrote a life of Mary of Oignies, in which he presented her and other holy women of Liège as models of holiness and the female religious life. This account of the holy women is addressed to Bishop Fulk of Toulouse, who was involved in the crusade against heretics in south-west France; according to Grundmann, James of Vitry wrote the vita in order 'to be able to present to the southern-French heretics an effective portrait of a "modern saint"'.6 These women rejected the wealth of their homes, fearful of the dangers of worldliness. ${ }^{7}$ James of Vitry also thought highly of anchorites who removed themselves from the world. In a sermon to hermits, solitaries and anchorites, he described their way of life as one in which the normal order had been reversed: their confinement became freedom, allowing the soul to transcend its carnal chains. ${ }^{8}$

There had also been cases of individual men supporting religious women in the twelfth century, most notably Gilbert of Sempringham and Robert of Arbrissel, who established houses for women in, respectively, England and France. Robert of Arbrissel had gathered round him women of all classes; but the house he established, Fontevraud, while growing rapidly under the charge of its first abbess, Petronilla of Chemillé (interestingly, she was the superior for men and women at Fontevraud), and establishing many daughterhouses, became increasingly aristocratic. Women in religious houses always required the presence of men, as lay brothers for practical help and, more importantly, as clerics for pastoral support and the administration of the sacraments, but the proximity between men and women always led to the possibility of scandal, if not actual promiscuity; inevitably, the double foundations changed, often to the disadvantage of the women. The anxiety among Gilbertines was heightened by the scandal of the nun of Watton, when a nun who had entered the nunnery as a young child became pregnant by one of the brothers 'to whom the care of external affairs was 
entrusted'. 9 This story was recounted as a miracle by Aelred of Rievaulx, since the repentance of the nun led to the disappearance of the pregnancy and apparent restoration of her virginity. ${ }^{10}$ The fear of scandal, however, was a real problem; the nuns felt that their collective virginity had been assailed. ${ }^{11}$ Gilbertine houses founded from the end of the twelfth century tended to be for male canons only; the double houses of the Premonstratensian order were suppressed in the middle of the twelfth century; ${ }^{12}$ the female communities attached to the Flemish abbey of Augustinian canons at Arrouaise were also limited and eventually discarded in the thirteenth century. ${ }^{13}$ By the end of the twelfth century, any new foundations for women tended to be single-sex. Despite the great growth in houses for women in the twelfth century, reaching a peak around $1150,{ }^{14}$ Bruce Venarde is able to argue that 'There always were, in the time and space considered here [that is, France and England prior to 1215], more women desirous of entry into the religious life than there were places for them'. ${ }^{15}$ The difficulties women seeking a place in a traditional nunnery would have encountered would undoubtedly have led some to seek alternative ways of fulfilling their vocations, but there are other reasons than the lack of places in nunneries for the rise of alternative forms of religious life for women, such as the beguine movement, in the thirteenth century.

The upsurge in lay piety throughout Europe led to a corresponding rise in the number of women seeking a religious life, but the pattern of support for women being subsequently tempered by fears leading to constraints being placed on the women is repeated in the thirteenth century. Following the Fourth Lateran Council, it was necessary that women wanting to pursue a religious vocation did so within an established order, but little provision was made for them. The Church was anxious to impose order and control on women, and the curia wanted existing, male, orders to take responsibility for women - a responsibility they desperately tried to avoid. Reformed monastic orders, such as the Cistercians, were particularly reluctant to accept responsibility for women, whom they saw as a threat to their salvation. A number of nunneries claimed allegiance to the Cistercian order and individual Cistercian 
abbots did take responsibility for some of them, especially in Spain, ${ }^{16}$ while in the Low Countries the abbot of Villers was prepared to provide spiritual guidance for women's convents, ${ }^{17}$ and other Cistercian foundations provided beguines 'with protection, spiritual guidance, and material sustenance through land grants and pensions'. ${ }^{18}$ Dominican friars were often responsible for the pastoral care of beguines, ${ }^{19}$ and later in the thirteenth century many women, especially in southern Germany, entered Dominican women's houses, 'which continued the traditions of the beguinages' ${ }^{20}$ It is not always clear to what order some houses of nuns were affiliated; in Lincolnshire in the thirteenth century, for example, some houses determinedly claimed to belong to the Cistercian order - partly because of the financial benefit - although the abbot of Cîteaux denied their affiliation. The confusion is not due just to incomplete records, or inadequate history; Elizabeth Freeman comments on the 'fluidity and flexibility of female institutional affiliation', as the communities themselves would claim different affiliations as it suited them and their circumstances. ${ }^{21}$

The position of women was always more marginal, and so more difficult to define, than that of men, and those women who could not claim membership of an established religious order - notably anchoresses and beguines - were particularly marginal and vulnerable, although some derived strength and independence from this very marginality. While the ecclesiastical hierarchy continually attempted to impose enclosure on all female religious, many urban reclusae avoided strict enclosure and maintained freedom of thought and religious expression. Anneke Mulder-Bakker's recent survey relates specifically to northern Europe, and her comments on anchorites may not apply to the situation of English anchorites; nevertheless, what she does make clear is the variety of religious experience and styles of living women were engaged in during the high Middle Ages - and that these experiences often defied the ecclesiastical authorities. ${ }^{22}$

The beguines were the most important of the extra-religious groups of women on the Continent in the thirteenth century. Although contemporary accounts may have exaggerated the numbers, the definition Matthew Paris gave of women following a semi-regular life suggests something of their impact: 
At this time and especially in Germany, certain people - men and women, but especially women - have adopted a religious profession, though it is a light one. They call themselves 'religious', and they take a private vow of continence and simplicity of life, though they do not follow the Rule of any saint, nor are they as yet confined within a cloister. They have so multiplied within a short time that two thousand have been reported in Cologne and the neighbouring cities. ${ }^{23}$

In his account in the Historia Anglorum, also for 1243, Paris refers to such people who assumed the appearance and way of life of religious as 'Beguinos sive Beguinas'. ${ }^{24}$ Robert Grosseteste, comparing the life of Franciscan friars with that of beguines, claimed, according to Thomas of Eccleston, that that of the women was superior, since they lived by their own labour and were not a financial burden on anyone. ${ }^{25}$ Not all beguines lived up to such an ideal; writing in the late thirteenth century, Nicholas of Bibra acknowledged that 'good beguines work day and night', but that others 'connive under cover of a false religious leisure'. ${ }^{26}$

The women who became beguines tended to be from a different social class from those who had previously entered nunneries. The beguine movement was an urban phenomenon: although individual beguines may have had rural origins, ${ }^{27}$ beguines were often from the rising bourgeois class of the growing commercial centres of the Low Countries and northern France; a beguinage was established in the heart of the old commercial centre of Bruges in $1245 .^{28}$ There have been suggestions that the women who became beguines were 'surplus' women, who turned to the religious life because of the lack of husbands, a situation referred to as the Frauenfrage. The imbalance between the numbers of men and women available for marriage seems to be a matter of historical record, but its extent and why it should lead to a rise in this form of female spirituality are open to debate. ${ }^{29}$

The beguines were not a single organization, and the variety in the type of women who became beguines, their motives for making that choice and the lifestyles they followed, all make it nearly impossible to make general comments on them. They were all, however, occupying a liminal position between laity and religious similar to that of the anchoresses; it was a position 
that was difficult to maintain and fraught with danger. Increasingly, beguines were placed under ecclesiastical control: Paris's comment that they were 'as yet' enclosed seems prophetic. Early supporters, such as James of Vitry, saw the beguines as 'the hope of the Church, promising a new flowering of Christian piety'; ${ }^{30}$ others were deeply suspicious. While early beguines had been largely autonomous, living out their religious vocation in their own homes and small communities rather than in a nunnery or reclusiorum, and so largely beyond the control of the male ecclesiastical authorities, legislation was passed during the course of the thirteenth century to control and protect beguines, following complaints of abuse. The late thirteenthcentury regulations for the Beguinage in Bruges forbade beguines to leave the enclosure without reason and permission, ${ }^{31}$ and the mention of a Chapter, which had a regular ritual of repentance and which imposed specific penalties, suggests that the Beguinage was run on monastic lines. ${ }^{32}$ Simons asks who needed protection from whom: 'Behind the patronizing, caring measures taken to guard the beguines' moral and physical integrity, it is not difficult to perceive an inveterate suspicion of women's religious aspirations, which - in the view of many required confinement as much as support.' 33 Whatever the chronological story of the development of formal beguinages from the early ad hoc associations of women, the picture that emerges is one of fluid, experimental forms of organization that provided a vocation for religious women. The plastic shape of these organizations was moulded by a variety of social and ecclesiastical pressures.

While we should give precedence to the spiritual reasons for choosing a religious life, social and economic factors in the rise of the beguine movement also need to be taken into account. Brenda Bolton suggests the near inseparability of social and religious factors in assessing the rise of the beguine movement:

In the Low Countries the beguines formed a movement which reflected the increasing numbers of women who were seeking places in which to fulfil their religious aspirations ... the existence of these large numbers reflected both the quickening urban development of the Low Countries and, simultaneously, the occurrence of the latest of the line of outbursts of religious piety. ${ }^{34}$ 
The attraction of a way of life that was independent of marriage needs to be balanced by an appreciation of the spirituality and religiosity of these women; economic factors are not sufficient to explain the rise of the women's religious movement in the thirteenth century. Beguine houses could offer a charitable refuge for unmarried and widowed women, but 'they were also retreats for the contemplative'. ${ }^{35}$ Hoornaert, in his introduction to the rule of the Bruges Beguinage, argues that it is time to abandon the romantic notion that these women were widows or young waifs and strays seeking a refuge from the world: 'The contrary is true. In the charter of the Vinea of Bruges of 1245, we see souls clearly seeking the path to a life of lofty contemplation and systematic prayer in seclusion from the world.' 36

Some women who chose the religious life were already married, as was Mary of Oignies who persuaded her husband also to enter the religious life when she joined a community of women as a conversa attached to a house of Augustinian canons. Nor can it be claimed that beguines were seeking a refuge from poverty; while provision was made for poor beguines, it was usually expected that women entering beguine communities would bring property with them. In the prologue to his vita of Mary of Oignies, James of Vitry wrote with approval of women who left wealthy families to live in poverty; it seems the women entering beguine communities often did so in order to renounce wealth, not because they had no wealth.

Although there are examples of extreme behaviour on the part of beguines, this was not a pattern that was encouraged. Penny Galloway has argued that 'The spirituality expressed by these exceptional women was, almost by definition, atypical. ${ }^{37}$ James of Vitry, while presenting the lives of Mary of Oignies and other holy women of Liège as 'exempla', also admitted that he could not commend the excesses that Mary committed in, for example, wearing a rough cord under her clothing. ${ }^{38}$ James handles with care the story of Mary cutting out a large piece of her flesh with a knife because of her loathing for it: she did this needlessly, 'from the fervour of her spirit and as if inebriated', which allowed her to rise above the pain. She then buried the piece of flesh in the earth 'with shame'. ${ }^{39}$ While James of Vitry 
admired her fervour and believed that she was blessed in her ecstasy, this is presented as exceptional behaviour. In order to negotiate a space where such behaviour can be related with approbation, while not being presented as a model to imitate, Mary's actions are presented with the understanding that she was a woman of exceptional spirituality and possessing a particular gift of grace.

James of Vitry and others preached sermons to beguines, and these sermons - as texts offering both spiritual advice and practical guidance - bear comparison with Ancrene Wisse. Such sermons (which will be discussed at greater length in a later chapter) often have the same moderate tone and emphasis on the endurance of suffering. As in Ancrene Wisse, the spirituality expressed is both penitential and contemplative. Suffering and privation in this world was, for the beguines as for the anchoresses, both the route to eternal happiness and the price to be paid for that heavenly reward.

The social position of the anchoresses for whom Ancrene Wisse was written, and the probable reasons for their choosing the anchoritic life, bear comparison with what we know of the early beguines on the Continent. The essential difference between the life of the beguines and that of the anchoresses was the strict enclosure of the anchoresses. It was within the physical confines of the anchorhold that the spiritual life of the anchoresses was constructed. The author of Ancrene Wisse was writing of the ideal of the anchoritic life, which, like that of the beguines, was chaste, ascetic and orthodox, but he was also aware of the opportunities for laxness. The anchoresses, unlike the beguines, were not expected to support themselves by their own work, but neither were they expected to be idle; theirs was a life filled with prayer, reading and meditation. The prayers and devotions were simpler than those used by nuns, but both beguines and anchoresses had a daily routine of prayers that followed the canonical hours. ${ }^{40}$

The daily devotions detailed in Part One of Ancrene Wisse are not the full canonical hours, but rather the Hours of the Virgin; this office was shorter and more appropriate for lay anchoresses, who 'lacked the discipline of the cloister'. ${ }^{41}$ There were additions: part of the Office of the Dead, and the 
Office of the Holy Ghost as a voluntary observation, ${ }^{42}$ and there were also groups of private prayers to be said at intervals through the day. ${ }^{43}$ By placing the instructions for the performance of the office in the first part of Ancrene Wisse one may be justified, as Robert Ackerman suggests, 'in assuming that ... [the author] meant to impress on his anchoresses the primary importance of the opus Dei in the life they had chosen'. ${ }^{44}$ It was the Little Office of the Blessed Virgin Mary, originally constituted as additional devotions to the Divine Office, that would form the core of the Books of Hours which became so important in the devotional lives of pious lay people in the later Middle Ages. The beguines in Bruges followed a life of prayer and contemplation, the base of which was probably the Office of the Virgin. ${ }^{45}$ Acts of penitence were also important: the beguines made their confession prior to Mass to their priest, but also made a confession to their sisters; public acts of repentance were made before the Chapter. ${ }^{46}$

Also comparable is a short 'riule' found in a thirteenthcentury manuscript that may come from northern France. ${ }^{47}$ Although called a 'rule' it is not a rule in any formal sense, and in this it can be compared with Ancrene Wisse which, 'presents itself as a rule', although there are many senses in which it is not a rule. ${ }^{48}$ The French 'riule' may have been intended for use by beguines or some similar quasi-regular group: it addresses a single, religious woman ${ }^{49}$ who is living in some sort of community, but not, it would seem, a traditional convent. The religious women for whom the 'riule' was composed are to occupy their days with prayers and meditations, and the text largely consists of these prayers and meditations; it contains extended meditations on the nativity and passion of Christ. As in Ancrene Wisse, the reader is advised to think on the pains of Hell and the rewards of Heaven. Those who remain virgins will dance in Paradise and sing sweet songs with their Queen, who is the Lady of all creatures. ${ }^{50}$ The final part of the text is an extended meditation on the Passion and Crucifixion, taken largely from the Gospel accounts.

Although it took a different form, the rise in anchoritism in England in the thirteenth century should be seen as a response 
to the same combination of social and religious factors as led to the development of the women's religious movement and, in particular, the beguines, on the Continent. There had always been more female than male anchorites in England, but between the twelfth and thirteenth centuries there was a dramatic increase in the number of anchoresses. Even given the vagaries of the survival of records, the increase in the number of anchoresses cannot be denied. Ann Warren suggests that the reason women in England chose anchoritism, rather than the variety of forms of religious life chosen by women on the Continent at this time, is the orthodoxy of England: it was 'a society whose religious needs were accommodated in traditional ways' ${ }^{51}$

Little is known about these sisters for whom Ancrene Wisse was originally written; there is some reference to their personal circumstances in the version found in the Nero manuscript, where the author reminds them that they have little need of support against the temptations brought about by hardship, since they have one friend who supplies all their needs. This passage also refers to them as well-bred 'gentile wummen' and 'sisters from one father and one mother, who in the bloom of [their] youth renounced all the joys of the world and became recluses'. ${ }^{52}$ It is clear that they were lay anchoresses; that is, they entered the anchorhold, not as professed nuns seeking a more austere form of life, but from the world - for them, the anchorhold was an alternative to the convent.

Anchorites were defined in the Rule of St Benedict as monks who chose the solitary life only after a long training in the community of a monastery, where they 'learned to fight against the devil through the skill acquired from the support of many'. ${ }^{53}$ It had been traditional for anchorites - male and female - to be professed religious who were seeking a harsher life. This seems to have been the case with the sister for whom Aelred of Rievaulx wrote De Institutione Inclusarum, a work which the author of Ancrene Wisse acknowledged as an influence, ${ }^{54}$ although the only evidence that his sister was a professed nun seems to be Aelred's statement, 'I tell you, if you have more food and more clothes than you need for yourself, you are no nun'. ${ }^{55}$ The opening paragraph of $D e$ 
Institutione Inclusarum does, however, refer to a Benedictine model of anchoritism: 'You must first understand the reasons that motivated the monks of old when they instituted and adopted this form of life ... The monks of old then chose to live as solitaries for several reasons. ${ }^{56}$

By the thirteenth century, however, most anchoresses in England were 'lay'. ${ }^{57}$ We need to be cautious about the use of the term lay: it should not be understood to mean the antithesis of religious. Although not members of a religious order, the anchoresses were religious in that they had taken vows and followed a religious life under ecclesiastical authority. To call the anchoresses for whom Ancrene Wisse was written 'lay' may be useful in drawing attention to the fact that they had not entered a convent and that, while able to read, they were not greatly learned, but otherwise terms such as 'quasi-religious' or 'semi-regular' are more useful in suggesting their liminal and rather anomalous status. However, by referring to the anchoresses for whom Ancrene Wisse was originally written as lay, rather than nun, anchoresses, we are placing them in a significant religious movement of the high Middle Ages: the development of lay piety and the women's religious movement.

The fact that Ancrene Wisse was written in English also suggests that its initial readers were lay. The terms laicus and illiteratus were often considered synonymous, illiteratus meaning unable to read Latin; anyone who was clericus would, by definition, have some knowledge of Latin and so be literatus. In Middle English, the term lay tended to indicate non-clerical or non-learned: the first reference to the adjective lai in the Middle English Dictionary is from around 1400 and gives the meaning of 'unlearned, uneducated' or 'non-clerical, not belonging to the priesthood'. ${ }^{58}$ The word lai is not used in Ancrene Wisse, but in the final part, when the anchoresses are advised to take communion 'as our brothers do', the version in the Nero manuscript has the word leawude before bredren, suggesting that the anchoresses should follow the customs of the lay brothers in a religious community. ${ }^{59}$ The anchoresses, however, were religious, in that they took solemn religious vows of chastity, obedience and stability of abode. ${ }^{60}$ Alexandra Barratt has suggested that the use of the vernacular 
in Ancrene Wisse probably has more to do with the lay status of the anchoresses and their lack of opportunity to learn Latin than with any decline of learning among nuns after the AngloSaxon period; ${ }^{61}$ in other words, while Latin was still being learnt by nuns, English was the appropriate language for a religious work aimed at a lay, middle-class audience in the first half of the thirteenth century.

The reason the anchoresses did not enter a convent may have been purely pragmatic: there were not many places in convents in the part of England, Herefordshire and Shropshire, in which the dialect of Ancrene Wisse would place the sisters in the early thirteenth century. ${ }^{62}$ The few houses that there were in the area, such as Limebrook and Aconbury in Herefordshire and Brewood White Ladies in Shropshire, with Brewood Black Ladies just over the border in Staffordshire, were small. Brewood Black Ladies, for example, was a community of Augustinian canonesses established before the end of Henry II's reign. Its usual quota was a prioress and five nuns, and it relied on 'small gifts from local families of modest wealth'. ${ }^{63}$ The thirteenth century was a period of growth in the West Midlands, and there were wealthy lay and ecclesiastical landowners, but the wealthy ecclesiastical landowners tended to be the old Benedictine communities and there is no mention of female religious sharing in this wealth. ${ }^{64}$

There were few opportunities for three gently born sisters wishing to pursue a religious vocation, but their choice of the anchoritic life can also be interpreted as part of the shift in the conception of what constituted the religious life at this time. The reclusive life was one way in which those not belonging to a religious order could imitate Christ.

Lay anchoresses in England in the high Middle Ages were still under the authority of the Church: all anchorites had to have permission from the bishop of the diocese in which they were to be enclosed and to be able to prove, not only religious vocation and dedication, but also financial security, so they would not be a drain on the diocese for upkeep. ${ }^{65}$ We have seen that the anchoresses for whom Ancrene Wisse was written had a patron who supplied them with all their needs; patrons who endowed an anchorhold felt that they were in 
some way participating in the spiritual vocation and endeavour of the anchorite: 'To understand why people supported the solitary movements is to comprehend the awe that the asceticism of the recluse engendered within the larger community and to acknowledge the perceived value of the ascetic's intercessionary powers.' ${ }^{26}$ Many people in their wills would remember all the anchorites in the area. The 'otherness' of the anchorites was emphasized by the enclosure ceremony, which included the burial service - in entering the new life of the anchorhold, the anchorites died to the world.

Nevertheless, this new, penitential life of the anchorite was one in which people still in the world could, to some extent, participate, not only through patronage but also through their own prayers and devotions. Ancrene Wisse was written at a time when religious literature was moving out of the monasteries and churches; its popularity beyond the enclosure of the anchorhold, as we will see, suggests a large lay readership. 


\section{4 \\ Anchoritic spirituality}

I have suggested that the women's religious movement in northern Europe in the twelfth and thirteenth centuries was not just a social or economic phenomenon, but the product of a new religious sensibility. The same can be said of anchoresses in England in the high Middle Ages. We have seen that there was an increase in the number of anchoresses at this time, and that they were mostly lay anchoresses; the anchoresses for whom Ancrene Wisse was written can be considered typical of their vocation in the thirteenth century. There is a reference in the Corpus Christi version to the increase in the numbers of the anchoresses of England, 'twenty now or more', who were all presumably following a life similar to that of the original three sisters. ${ }^{1}$ Most anchoresses, like the beloved sisters of Ancrene Wisse, would have come from the gentry classes, the increasingly literate and wealthy middle classes. They were claiming a new form of piety for themselves, one that responded to the spiritual climate of the period: a piety that was affective but not confined to the monasteries.

It is this piety that is expressed in Ancrene Wisse; it is in keeping with the piety of the age and the democratization of spirituality that was an adjunct of affective piety. From the twelfth century affective piety - emotional response to religious images and ideas as the expression of a spirituality founded on belief and faith in a God present to humanity in the person of Jesus - was expressed as devotion to the suffering Christ and to the Virgin Mary as the human mother of Jesus. The spiritual enthusiasm of the period did not only affect those living dedicated religious lives; it led many lay people to attempt to imitate Christ in their own lives and was the motivation for many religious movements, not all of them 
orthodox. Imitatio Christi was also the driving force behind the rise of the mendicant orders at the end of the twelfth century: the mendicants of the early thirteenth century saw imitation of Christ as following his injunction in chapter 10 of the Gospel of St Luke, to go into every city preaching and healing. This injunction, or regula apostolica, was the focus of the way of life for Dominicans; preaching became the essential element of Dominican understanding of the regular life, and in this they broke away from the previous eremitical interpretation of the vita apostolica that was central to monasticism. ${ }^{2}$

The spirituality of Ancrene Wisse is affective, and links can be made with the development of popular piety, but the devotional practices advocated are orthodox and in large part derived from monastic models. The ideal of imitating Christ in his humanity developed through the high Middle Ages, though this could take different forms. The imitation of Christ's humanity was central to Cistercian spirituality, but it was also manifest in lay devotions: lay people, following the monastic model promoted by Cistercians, turned to images of a human Christ suffering on the cross and a human virgin Mary suckling her baby. At the same time, a 'theology of humanism' 3 developed in the monasteries, and theology emerged as an academic subject in the cathedral schools. The theological working-out of the Incarnation developed in parallel to the increased affective response that is discerned in the late twelfth and thirteenth centuries, and it may not be possible to assign cause and effect to these two aspects of the same spiritual history.

The emphasis on the human aspect of Christ can also be seen in devotion to the Passion of Christ and to Mary, as the mother of God. The celebration of the Eucharist - when the consecrated Host became the body and blood of Christ - was the perfect devotional expression of the Incarnation; in consuming the body and blood the communicant became one with Christ - a perfect act of imitation. ${ }^{4}$ The theology of transubstantiation is linked with the philosophy of the Incarnation and the understanding of the physical presence of Christ; eucharistic piety among the laity was an affective and emotional response to the belief in the presence of God in the 
consecrated Host. Pierre-Marie Gy places the development of the eucharistic cult in the twelfth century in the context of devotion to the humanity of Christ, and claims that:

the devotion to the humanity of Christ undoubtedly played a stronger role than the theological debate in the development of eucharistic cult. Eucharistic piety addressed itself to Jesus on the cross, whereas eucharistic theology concentrated on the consecration and presence of Christ in the Eucharist rather than on the memorial of his passion. ${ }^{5}$

Incarnational spirituality, expressed in devotion to the Passion of Christ and in eucharistic piety centring on the presence of Christ in the consecrated Host, is at the heart of Ancrene Wisse. The spirituality of Ancrene Wisse is essentially incarnational: within the anchorhold the anchoresses could share the suffering of their lover, Christ. While the author advised them against being too hard on themselves, an element of suffering was considered necessary -whatever they endured was as nothing in comparison to the sufferings of Christ. The anchoresses were likened, not to pilgrims, or even the dead, but to a third group, 'who are never happy unless they are suffering some pain or some shame with Jesus on his cross'. ${ }^{6}$ The life of the anchoresses was one of penitence and asceticism; it was through constant penitence and suffering, as well as her devotions, that the anchoress could imitate Christ's passion.

Mary Baldwin suggests that '[a] study of the spirituality of AW must begin with the text itself'? Ancrene Wisse was highly influenced by Cistercian spirituality - Bernard of Clairvaux is one of the most frequently cited authorities - but the author himself may have been a Dominican, and Ancrene Wisse reaches beyond the cloistered, monastic tradition which fed it. The very liminality of the status of the anchoresses is an important factor in understanding the spirituality of the work: their position was outside the normal framework of the religious life, yet Ancrene Wisse claimed for them a status that was superior to that of other religious, thus challenging the norm of religious. ${ }^{8}$ Liminality is normally understood as a process or temporary state, such as a rite of passage; for the anchoress it is a permanent state of being, but one that, of its very nature, defies permanence. The anchoress is vowed to 
stability of abode, but is a pilgrim travelling towards the heavenly Jerusalem; the cell in which she lives is usually supported by the community of either a village or a religious house, but she is dead to the world. The anchoress pursues her journey - her quest for heavenly bliss - within the confines of the anchorhold which provided the physical conditions - the protection and the privations - for the practice of a spirituality based on a personal relationship with Christ as God made man. She is suspended on the threshold between earth and heaven - a continuing moment of transcendence.

The life of the anchoress is a spiritual one, but the imagery used to express it is physical: the anchoresses consume Christ in the Host, embrace him as a lover and, in their imagination, enter the wounds of his body: 'Creep into them [the wounds] with your thought - are they not all open? and drench your heart with his precious blood.' ${ }^{9}$ Such descriptions are in keeping with the affective spirituality of the period as manifested in both devotion to the Passion of Christ and the belief in transubstantiation. The wine drunk at the Eucharist was the blood of Christ spilled on the cross. Ancrene Wisse describes both the life and the spirituality of the anchoress, and gives advice and guidance to those living this life. Ancrene Wisse is not primarily about the institution of anchoritism, but, rather, is about how the individual negotiates the world, with its fleshly desires, in the quest for heavenly bliss: anchoritism is one way - possibly the best - for this endeavour.

In the text, the Inner Rule, which rules the heart, is framed by the Outer Rule, expounded in the first and last parts; this can be seen as a metaphor for the anchoresses' spiritual lives, which are framed - and contained - by the anchorhold. It was understood that the anchorhold was a place of penitence and a prison; but the suffering endured there may allow the anchoress to escape the eternal torment of hell. ${ }^{10}$ The physical hardships the anchoresses endure are for the sake of purifying the heart; they have no intrinsic value:

Just as tools are not valued for their own sake, but only for the things that are done with them, so no physical hardship is to be valued except for this reason, that God looks towards it sooner with his grace, and purifies the heart and gives it clear sight. ${ }^{11}$ 
The anchorhold is also a haven, allowing refuge from the temptations of the world and giving the anchoress the opportunity of spending time in prayer and meditation. The incarnational spirituality of the anchoress is intimately related to her way of life: its enclosure, stability and privations are ways in which she is able to express her relationship to God and to imitate Christ.

Enclosure had both symbolic and material meaning. While the privations of asceticism allowed the anchoresses to identify with the suffering of Christ, their strict enclosure removed them from the world and meant that they were dead to the world. Their enclosure and the burial service said when they were enclosed were symbolic, but it would not do justice to the anchoresses, or to medieval imagination, to dismiss how they experienced the symbolic as mere rhetoric or empty ritual. Such symbolic acts allowed the anchoresses to interact with a spiritual dimension. Jacques le Goff claims, 'IndoEuropean tradition had evolved a way of interpreting space symbolically', and argues for the importance of spatial orientation:

In the Middle Ages the most important oppositions were up/down and inside/outside ... In medieval Christian ideology positive value was ascribed to high and inside. Ascent and internalisation constituted an ideal. Here the narrative unfolds entirely in the other world, a new other world that held out a prospect of hope, of enhanced likelihood of salvation thanks to a purgative and punitive ideal. ${ }^{12}$

Enclosure within the anchorhold made real the commitment of the anchoresses to the life of the spirit and their death to the material world. Their incarceration in the anchorhold is likened to the enclosure Jesus experienced in his earthly life and death, and allows them to share in his life, making explicit the imitatio Christi that is at the heart of their lives:

If, then, you endure bitterness in a narrow place, you are his companions, enclosed as he was in Mary's womb. Are you confined inside four spacious walls? He was in a narrow cradle, nailed on the cross, closely confined in a tomb of stone. Mary's womb and this tomb were his anchor-houses. ${ }^{13}$ 
In Part One, after a series of devotions to the cross, the anchoresses are to meditate on the majesty of God confined on earth. They use a series of invocations in Latin taken from the Confessions of St Augustine, ${ }^{14}$ asking that God should enter their hearts, but 'The house of my soul is too narrow for you; may it be enlarged by you' ${ }^{15}$ It is in his Confessions that Augustine described the perception of God - what is described as a mystical union - and there is a suggestion that the enclosure of the anchorhold may provide the conditions for contemplation of God. These are prayers and invocations to be said and meditated upon during Mass, and the suggestion that at this point God may enter the hearts of those praying is reinforced by the advice to the anchoress to embrace her lover, who has descended from heaven, in her heart. ${ }^{16}$

Throughout Ancrene Wisse, the anchoritic life is presented as an imitation of Christ's passion and death on the cross. In Part Three, reasons for maintaining solitude are given, and the anchoresses are reminded that 'you are enclosed with Jesus Christ as if in a sepulchre, pinned down as he was on the precious Cross'. ${ }^{17}$ The anchoresses share the suffering and shame Christ endured on the cross: 'all their joy is in being hanged painfully and shamefully with Jesus on his cross' ${ }^{18}$ Jocelyn Wogan-Browne quotes a variation of this comparison with the enclosure of Christ from Clemence of Barking's Anglo-Norman St Catherine:

Christ placed himself in a narrow dungeon when he took our humanity. He whom the whole world cannot contain lay for a long time in a womb. But he encompasses the entire world and all creatures within it . . . For love of him, I shall gladly accept the darkness of this dungeon which I see here, for he did much more for me. I must tell you that in return for this darkness such sight will be given to me that no tempest of chill wind will ever dim it.

Wogan-Browne comments that, 'This is very different from the topos as deployed by the Guide [that is, Ancrene Wisse], but here, as in Ancrene Wisse, there is a desire to participate in the experience of Christ'. ${ }^{19}$ And, as in Ancrene Wisse, there is a joyful acceptance of the confinement in anticipation of the freedom that is to be its reward. The editors of the English 
versions of Aelred's De Institutione Inclusarum suggest that, in contrast to Aelred's work, Ancrene Wisse presents 'the idea of the glad and willing, almost gay and chivalrous acceptance of suffering'; ${ }^{20}$ through imitating Christ's suffering, the anchoresses will share in his bliss: 'if we live for his sake in shame and pain, in both of which he died, we shall imitate his joyful resurrection, our bodies as bright as his, world without end'. ${ }^{21}$ The bright bodies recall the morning-gifts, 'swiftness and the illumination of clear sight', promised to the anchoresses as brides of Christ. ${ }^{22}$

The Passion of Christ also offers a refuge for the anchoresses; towards the end of Part Four, an image from the Song of Songs, of a dove hiding in the clefts of a rock, is interpreted as the anchoress taking refuge and shelter from the temptations of the world in the wounds of Christ. The identification of the clefts in the rock with the wounds in the body of Christ is a traditional one; it can be found 'as early as Gregory's In Cantica', ${ }^{23}$ and the image of the wounds of Christ as 'holes in the rock where we may take refuge' 24 is found in the writings of both Bernard of Clairvaux and his follower, Guerric of Igny. In his Sermones super Cantica Canticorum, Bernard associates the image of the wounds as clefts in a rock with that of Christ as the rock, suggesting security and safety; ${ }^{25}$ while Guerric of Igny suggests that the dove finds in the wounds of Christ not only a refuge, but also union with God. ${ }^{26}$ The incarnation and humanity of Christ were important elements in Cistercian spirituality, itself a major influence on the spirituality of Ancrene Wisse, but, as Savage and Watson point out, the passage from Part Four is also 'one of the earliest English expressions of the devotion to the wound in the side, which was to become popular in the fourteenth and fifteenth centuries'. ${ }^{27}$ Here we can see an example of how the spirituality of Ancrene Wisse occupies a position on the cusp between traditional monastic ideas and images, and their adaptation for late medieval popular devotion.

As the relationship with Christ is emphasized in the lives of the anchoresses, so they are distanced from the world outside the anchorhold. Through the virtue of their virginity, which symbolizes their dedication to God rather than to man, they 
are as exiles, strangers in a strange land: 'as if in a strange land and in a strange country among foreigners' ${ }^{28}$ The same idea is present in Hali Meiðhad, which may have been written for anchoresses, although what it says would apply 'to any virgin entering the religious life': ${ }^{29}$ the virtue of virginity, which foreshadows the immortal bliss of heaven, is an outlaw in this 'land of unlikeness' - it retains the nature of the angels but is imprisoned in a 'body of clay'. ${ }^{30}$ Similarly, James of Vitry claimed that Mary of Oignies 'languished in exile' in this world; ${ }^{31}$ the vita of Mary was written in 1215, two years after her death, and so is contemporary with Ancrene Wisse. These virgins, exiled in this world, are journeying towards their heavenly home; two dynamics can be discerned in this journey - aspiration to union with God and the resistance of worldly temptations. There is a suggestion that they can experience in this world a foretaste of heavenly bliss in union with God through Christ as their heavenly bridegroom. In Hali Meiðhad, for example, the virginal life itself foreshadows heavenly life:

This virtue [that is, virginity] is the only one that in this mortal life foreshadows in itself a state of the immortal bliss in that blessed land where bride does not take groom nor bridegroom bride; and teaches here on earth by its way of life the way of life in heaven. ${ }^{32}$

Ancrene Wisse suggests that the virginal life is a preparation for the heavenly life, when the anchoresses will be the brides of Christ.

The anchoritic life was a solitary one, and the anchoress is likened to a solitary sparrow. ${ }^{33}$ The solitary life is also a silent one, and through silence the anchoress prepares herself to sing in heaven: 'For anyone who is often quiet, and keeps silence for long periods, can certainly hope that when she speaks to God, he will listen to her; she can also hope that, because of her silence, she will sing sweetly in heaven.'34 For Aelred, writing to his sister the anchoress, silence was not just not speaking, but also being open to the presence of Christ: 'she [that is, the anchoress] must sit alone, imposing silence on her tongue that her spirit may speak; believing that when alone 
she is never alone, for then she is with Christ, and he would not care to be with her in a crowd'. ${ }^{35}$ Aelred stressed that the anchoress 'should put a curb on her lips', ${ }^{36}$ and it is in this sense of curbing, or controlling, the senses, that silence is so important in Ancrene Wisse: through silence the anchoress guards her heart since the five senses are the guards of the heart. ${ }^{37}$ Silence is one of the privations and mortifications the anchoresses must endure and that prepare them for the bliss of heaven.

If asceticism expressed through a life of privations was one way in which the anchoress could imitate Christ, she could also partake in his passion through the Eucharist. The celebration of Mass was central to the daily lives of the anchoresses, as described in Part One of Ancrene Wisse; it was within this daily scheme of prescribed prayers and devotions that the anchoresses would hear Mass. Although they did not interact in any way with the priest and the action of the Mass, the anchoresses were given a series of prayers to say throughout the canon of the Mass, including a verse to say at the elevation, 'when the priest raises up God's body', 38 followed by greetings to be said while kneeling. These prayers are in Latin, but the anchoresses are here partaking in a devotional act similar to that participated in by lay congregations, who were advised of prayers to say during the Mass. ${ }^{39}$ God incarnate was visibly present in the consecrated Host, and devotions centring on the elevation, when the consecrated Host was raised for the adoration of the people, became, as we shall see, an important feature of lay piety. The same piety is present in Ancrene Wisse, and the anchoresses' prayers occupy a nexus between monastic and lay devotions. The prayers and meditations prescribed for the anchoresses build up to an intensity of feeling during the Eucharist until, at the moment the priest communicates, they are advised to embrace Christ in their hearts as a lover. ${ }^{40}$ This seems to be related to the concept of vicarious communion: the idea that the priest communicates on behalf of the people was expressed by Otto of Bamberg in the early twelfth century, while the important liturgical writer Durandus suggested that although the people receive the holy sacrament only three times a year, the priest receives it 'daily for all'. ${ }^{41}$ This moment 
does not occur when the anchoresses themselves receive communion, which they did only fifteen times a year, ${ }^{42}$ but rather every day when they hear Mass. The devotions of the anchoresses were centred, not on the consumption of the body of Christ, but on his presence to them. This moment of ecstasy is at the heart of the spirituality of Ancrene Wisse, a spirituality that is orthodox and sacramental, but also deeply personal.

It was God's body they saw elevated daily in the celebration of the Eucharist, and him they embraced; Christ sacrificed on the cross is also the lover of the anchoress. The association between consuming the body of Christ in the consecrated Host and embracing him is found in the Libellus de Diversis Ordinibus: 'Such is the body of Christ I believe in, hold, embrace, consume, absorb into my innermost entrails. ${ }^{43}$ Whatever order a religious should belong to, they should all seek to imitate Christ: 'it is fitting for each of these people to "bear in his body the mortification of Christ"' (2 Cor. 4-10). Unless they have observed this, they cannot attain the Holy Spirit. ${ }^{44}$

For the anchoresses, a constant reminder of the mortification of Christ was the crucifix in their cell to which they prayed saying salutations in commemoration of God's five wounds, ${ }^{45}$ and the great cross they could see in the church. At midday - after hearing Mass - they were to meditate on God's cross and his cruel suffering. ${ }^{46}$ Christ crucified is a haunting presence throughout Ancrene Wisse, both on the cross and in the sacrament. When the anchoresses first rose in the morning, they were to think of 'God's flesh and his precious blood, which is above the high altar', that is, the reserved sacrament, and they knelt before the crucifix, saying salutations in commemoration of Christ's five wounds. ${ }^{47}$ The crucifix on which the anchoresses were to fix their gaze and which would inspire their meditations probably depicted a dying Jesus. The description of a crucifix given in Part Seven suggests the 'three-nail' type, introduced into England around 1200, where one foot is placed over the other and one nail driven through both..$^{48}$ The triangular shape this created allowed the comparison of the crucifix with a shield, the consequent associations with chivalry allowing Christ to 
be depicted as a knightly lover. This depiction of the cross as shield occurs in Part Seven, which, it is announced at the end of Part Six, is 'all about the love which makes the heart pure'. ${ }^{49}$ Part Seven begins with a reference to St Paul, who 'testifies that all external hardships, all mortifications of the flesh and physical labours count as nothing compared with love'. ${ }^{50}$ There is an apparent shift here from the mortifications of the flesh and suffering, which have been paramount in the account of spirituality so far: physical hardship is only a tool to achieve spiritual grace. God is still encountered, however, through the incarnation of Jesus. A story is told of a lady wooed and rescued from her enemies by a noble king, who is Jesus, Son of God. In a narrative replete with complex symbolism, the king enters a tournament like a bold knight, with a shield, his body, hiding his divinity. It is through this mortal shield that he is pierced, and the cross, the means of the death of Jesus, is likened in shape to a shield, broad above where his arms are outstretched, and narrow below where one foot is fixed on top of the other. ${ }^{51}$

Christ the lover cannot be separated from Christ crucified. Through their lives of humility and penance, true anchoresses share the pain and shame suffered by Christ on the cross; ${ }^{52}$ they also draw close to him as their lover, who promises them the bliss of heaven as their marriage-gift and as a reward for their suffering on this earth:

you will have in the next the clear view of the face of God, the source of all joy, in the bliss of heaven, much before the others. For a just God has decreed that each person's reward in the next world should correspond to the labour and the trouble that they patiently suffer in this world for his love. That is why it is proper that anchoresses more than others should have these two marriage-gifts, swiftness and the illumination of clear sight: swiftness in return for their being so closely confined now, the illumination of clear sight in return for making themselves obscure now in this world, and refusing either to see anyone or to be seen by them. ${ }^{53}$

The language used when the anchoresses are urged to embrace Christ at the moment of the priest's communion resembles a verse from the Song of Songs: 'I found him whom my soul 
loveth: I held him and would not let him go' (3: 4). James of Vitry also used the language of the Song of Songs when writing of the eucharistic piety of the religious women in the diocese of Liège. The Song of Songs was one of the most popular of the books of the Old Testament in medieval exegesis; its language, which had formed the basis of much of Cistercian spirituality, was now becoming available for a wider audience.

In a number of ways - in the devotions prescribed, in the liminal status of the anchoresses for whom it was originally written and in the nature of its spirituality - Ancrene Wisse occupies a transitional position: its roots are in monasticism, but it anticipates the developing lay piety of the thirteenth and fourteenth centuries. The fact that Ancrene Wisse was written in the vernacular in the first half of the thirteenth century and is one of the earliest prose religious texts in Middle English - means that it can be seen as a part of the history of the literature of lay piety, as much as (if not more than) a traditional institutional product. The spirituality evinced by Ancrene Wisse - a spirituality that is incarnational and affective - is also the spirituality that motivated the growth in lay piety. Incarnational spirituality, expressed in devotion to the Passion of Christ and in eucharistic piety, centring on the presence of Christ in the consecrated Host, penetrated all areas of devotional life. 


\section{5 \\ Lay piety}

The main feature of popular spirituality in the high Middle Ages was affective piety, the expression of a spirituality founded on belief and faith in a God present to humanity in the person of Jesus. Affective piety was manifest in the focus on the elevation of the transubstantiated Host at Mass, and also in devotion to the Cross and to Mary as the mother of God - forms of piety that were available to lay people. The celebration of the feast of Corpus Christi, instituted in the thirteenth century, ${ }^{1}$ is the ultimate form of devotion to the body of Christ. The relationship between Church and laity shifted as a more personal response to God became central to lay spirituality; the role of the laity in the divine economy could not be taken for granted, but needed to be given attention. Morris argues that there was also a 'colonization of inner space', as theologians, especially Cistercians, became interested in the workings of the human spirit, putting a new emphasis on intention, and that these ideas

were directed in the first place to an audience of monks and scholars, but they show a kinship with developments in wider strata of society: pilgrimage and the cults of the cross, the Blessed Virgin, and Mary Magdalene echo Cistercian meditations on the heavenly Jerusalem, the passion, the incarnation, and penitence. ${ }^{2}$

Affective piety describes the emotional response of the people to a spirituality that emphasized the incarnational aspect of Christianity: Jesus was God made man. This incarnational spirituality was the motivation for the lay devotions of the period and penetrated all areas of devotional life, from the liturgy of the Eucharist to popular devotions to the cross and the wounds of Christ. ${ }^{3}$ The identification with God through 
his incarnation in Christ, a man who suffered and died, enabled people aware of their own humanity to start on the journey towards God through an imitation of the life and passion of Christ. Bynum suggests that in this period, 'The fundamental religious drama is now located within the self, and it is less a battle than a journey - a journey toward God.' ${ }^{4}$ Ancrene Wisse can be read as a guidebook for this journey, and there are elements in the text that foreshadow developments in lay piety.

Christ crucified on the cross was at the heart of the affective piety of lay people in the high Middle Ages; through his sacrifice it was believed he redeemed mankind, and that sacrifice was re-enacted in the Mass. Meditation on the Passion of Christ and devotion to the crucifix were central to the spirituality of Ancrene Wisse. In a sequence of prayers before the cross to be said at midday, the hour of Christ's crucifixion, the anchoresses meditate on God's cross and his cruel suffering. ${ }^{5}$ Devotion to the crucifix and to the consecrated Host are linked; the body of Christ present in the Host and represented in the crucifix are both worthy of devotion as reminders of his sacrifice.

The Eucharist occupied a central place in the daily lives of the anchoresses; lay people would attend Mass less often, but among the laity eucharistic piety was an affective and emotional response to the belief in the presence of God in the consecrated Host. The people were sensually involved with the ceremony of the elevation: they could see the elevation, hear the ringing of the sanctus bell and smell the incense. Robert Grosseteste, Bishop of Lincoln in the mid thirteenth century, insisted on proper respect being shown to the Host when it was taken to the sick, it should be accompanied with candles, and there should be bells as well as lights, so that their sound would rouse the faithful to devotion. ${ }^{6}$ Miri Rubin writes of the elevation:

So by the early thirteenth century a focus for eucharistic awareness, a moment designed to encompass and communicate every aspect of the message which the church wished to convey, one which provided space for participation and for submergence in a ritual-communal moment, was in place. Taught, illuminated, heralded by the peal of bells, striking in its 
special lights and effects, it was attractive as a moment of encounter with the very Christ, from which some very real physical and spiritual benefits flowed. ${ }^{7}$

The renewed insistence of the Fourth Lateran Council that every adult should take communion at least once a year at Easter might suggest that people were reluctant to take communion; the attendance at church, however, seems to have been a regular part of life. Whatever the mundane realities of the parochial worship may have been, the Eucharist was one moment at which ordinary people found themselves in the presence of God. It was also the ritual which brought parishioners most closely in contact with the church and there was increasing concern that it should be celebrated properly. ${ }^{8}$ Grosseteste, for example, promoted propriety and the proper exercise of their duties by priests; in a letter to the archdeacons of his diocese of Lincoln, he wrote of the danger of an ignorant priest leading his flock astray: the cure of souls should not be entrusted to those not capable of fulfilling their duties. ${ }^{9}$ Alexander of Stavensby, Bishop of Coventry and Lichfield between 1224 and 1238, made similar points in the constitutions he published for his diocese: priests should act as an example to their parishioners and the sacrament of the altar should be treated with the reverence due to the presence of God and as a reminder of the final call to his presence. ${ }^{10}$ Stavensby, who had taught Dominic and his earlier followers when he had been a lecturer at Toulouse, continued to be a patron of the Dominicans, while Grosseteste favoured the Franciscans: both bishops were clearly impressed by the preaching mission of the mendicant orders.

In the ritual of the communion, the passion and sacrifice of Jesus Christ were replayed; it was through this ritual reenactment of sacrifice that Christians could partake in the death of Christ and so also share in his resurrection, which was deemed necessary for salvation. The priest repeated the very words Christ was recorded as saying at the last supper as a revelation of his approaching death: 'This is my body.' ${ }^{11}$ As Christ's words were believed to constitute the action of consecration, so, by repeating the words, the priest repeated the consecration. It was only the priest who had the power to 
consecrate the Host - to transform the bread and wine into the bread and blood of Christ - and at this moment he was believed to be truly Christ-like. It was this moment of consecration, rather than the reception of communion, which became the focal point of devotion.

Mass was no longer a communal activity, as it had been for the early Church; ${ }^{12}$ the people were separated from the altar by the physical presence of the rood-screen, and from the 'cultic acts' of the priest, since the liturgy was in Latin. ${ }^{13}$ The canon of the Mass, the part of the service in which the consecration and elevation took place, was silent, or whispered inaudibly: ${ }^{14}$ it was presented as a mystery, beyond the comprehension of the ordinary laity. The consecration and the subsequent visible elevation of the Host, rather than the reception of communion, became the focal point of devotion for the congregation. The alienation of the congregation from the liturgy of the Mass led to the development of practices of lay piety separate from those of the priest. The Lay-Folks' Mass-Book, a book clearly intended for a readership of pious lay people, includes prayers to be said during Mass: readers are instructed to do reverence at the ringing of the sacring bell and a prayer is given to be said at the elevation; after the elevation there is a prayer for mercy: 'Lord, als pou con, \& als pou wille, haue mercie of me, pat has don ille.' 15

Incarnational spirituality involved the desire to imitate Christ in one's own life; to some extent, this could be achieved through suffering and self-denial. The enclosed life of the anchorhold allowed the anchoresses to dedicate themselves to asceticism, but even in the outside world suffering was accepted, not only as inevitable, but as necessary: Christ had redeemed humanity through his suffering, and it was through suffering that sinners could redeem themselves and obtain forgiveness. In Part Three of Ancrene Wisse, it is made clear that everyone has a debt to pay, and this debt is paid with suffering:

We are all in prison here, and owe God huge debts of sin ... The harm that is done to us, either through words or through actions, is our ransom, which we must redeem ourselves with, and settle our debts to our Lord, that is, our sins; because without a discharge, no-one is taken up out of this prison who is not hanged immediately, either in Purgatory or in the torment of hell. ${ }^{16}$ 
Suffering and tribulation were necessary parts of the Christian life, as is suggested in a sermon for the beginning of Lent: 'but I say unto you for truth, the more tribulation thou hast in this life of thy body, the better thou shouldest obey thy dear Lord and keep his behests'. ${ }^{17}$ This sermon is found in a manuscript from the first part of the thirteenth century, Lambeth 487, amongst a collection of sermons known as the Lambeth Homilies. These were sermons in English and designed for a lay audience. There is a continuing debate about the dating of the composition and collection of these sermons; Thomas Hahn gives a date of $c .1180,{ }^{18}$ but a reference to saying confession during Lent, prior to communion at Easter - and the apparent acceptance of this as a regular custom - in the sermon for the first Sunday in Lent would seem to place it after the Fourth Lateran Council. ${ }^{19}$ Although annual confession and communion were requirements prior to 1215 , Colin Morris points out that

The publication of the decree implies that annual confession and communion were not universal, and the requirement to publish it frequently and to enforce it upon pain of suspension from entry to the Church and prohibition of Christian burial strengthens the impression that a new requirement was being imposed. ${ }^{20}$

Bella Millett argues for placing these homilies, and those in Trinity B.14.52, in the context of the 'radical change in preaching and pastoral care' at the time of the writing of the manuscript; the homilies do incorporate older, Anglo-Saxon, material, but Millett argues that this 'should be seen (as Elaine Treharne has suggested) as part of an active response to contemporary developments in preaching and pastoral care'. ${ }^{21}$

Ancrene Wisse provides private prayers to be said by the anchoresses at intervals throughout the day; the scheduling of additional prayers between prime and terce 'has precedent in monastic observance', 22 but the prayers owe much to a contemporary popular tradition as well as to monastic habit. Most important of the private prayers seem to be those before the crucifix, ${ }^{23}$ at the elevation of the Host during Mass $^{24}$ and to the Virgin Mary: ${ }^{25}$ these are the devotions that were 
gaining popularity among the devout laity during the high Middle Ages. The use of the crucifix in churches increased, as returning crusaders and pilgrims to the Holy Land brought back relics. There was also, in the century and a half before 1200 , an increasing emphasis in the liturgy on memorials of the passion, crucifixion and entombment of Christ. ${ }^{26}$ It was in the thirteenth century that Jesus on the cross was portrayed, not as a living man with head erect, but as one dying. The representation of him with one nail through both feet, and the consequent bending of the knees and twisting of the body, allowed new interpretations and responses. The twisted body shape showed a dying man hanging painfully: 'It was no longer the static, hieratic icon of earlier centuries, in which suffering is borne stoically, but the dynamic representation of an imaginatively gripping (because mutable) and memorable (because more extreme) process. ${ }^{27}$ This representation was taken to extremes the Church eventually found unacceptable: in 1306 a 'crux horribilis' on display in a London church was condemned by the Bishop and ordered to be removed during the night. This cross lacked a cross-beam, and was probably of the German type known as a Gabelkreuz, with a distorted figure of Christ suspended from forking arms. ${ }^{28}$ There was a fear that devotion to such an image could take the form of superstitious dread rather than true piety. Nevertheless, until the Reformation, the crucifix on the rood-screen dominated every church in England and 'when at the climax of the mass the laity raised their eyes to see the elevated Host, they saw also the great Rood'. ${ }^{29}$ A sequence of prayers 'before the great Cross' are given to the anchoresses immediately after they are advised to embrace Christ in their hearts at the priest's communion, ${ }^{30}$ confirming the association between eucharistic piety and devotion to the cross.

Also related to a spirituality focused on the humanity of Christ was the development of the cult of the Virgin Mary during the twelfth century; the use of the Ave Maria is the most obvious form this cult took for the laity. The synodal statutes issued by Bishop Richard Poore were 'some of the most important diocesan legislation of medieval England'; 31 the version of the Salisbury statutes, reissued for Durham when Poore became bishop there in 1228 , include the insistence that 
priests should teach their parishioners, not only the Lord's Prayer and the Apostles' Creed, but also the 'salutation' of Mary. ${ }^{32}$ This was probably the 'short, biblical' form of the Ave, without the later petition prayer that was 'enjoined upon all the faithful' by the Synod of Paris of c.1210. ${ }^{33}$ Marian devotion was not only imposed from above, however; devotional use of the Ave goes back to the eleventh century, and devotion to Mary had long been popular in England. ${ }^{34}$ Devotions to the Virgin Mary in Ancrene Wisse take the form of meditations on the Five Joys: the annunciation, nativity, resurrection, ascension and assumption. Each short meditation is followed by a psalm and five complete recitations of the Ave Maria. ${ }^{35}$ Repetition of the Ave developed into the Rosary, which is a series of oral prayers, Ave Marias and Pater Nosters, with accompanying mental meditations on the life of Christ. Vita Christi meditations may have been incorporated by the fourteenth century, ${ }^{36}$ but in Ancrene Wisse the repetition of the Ave is associated only with meditations on the Virgin Mary.

The rosary was used by nuns, but was also important in lay piety since it could be used in private, both as a 'meditative exercise to supplement the mass', and as a prayer to be said during Mass for those unable to follow the Latin of the service. ${ }^{37}$ In Ancrene Wisse, provision is made for whoever does not know Matins and the other services of the Opus Dei: they are to say thirty Pater Nosters with Aves and Glorias. ${ }^{38}$ Millett suggests this is an example of the wide readership, lay and learned, assumed by the author. ${ }^{39}$ Similarly, in the late fourteenth century, Walter Hilton suggested different prayers for uneducated and learned men: 'The Pater Noster for lewid men, and psalmes and ympnes and othere servyce of Holi Chirche for lettred men'. ${ }^{40}$

There is evidence that the 'Psalter of the Virgin', that is, the repetition of the Ave Maria 150 times, was used by beguines in the thirteenth century; the rule for Sainte-Elisabeth de Gand, drawn up around 1236, prescribes the recitation of the Psalter of the Virgin each day under the direction of one of the beguines, who would also state a Mystery of the life of Christ or of the Virgin for each set. ${ }^{41}$ In the use of the Hours of the Virgin and the repetitions of the Ave Maria, the devotions set down in Ancrene Wisse can be compared with the devotional practices of 
other extra-monastic religious; these practices, which were adapted from monastic practices for eventual use in the wider lay community, suggest the transitional position of Ancrene Wisse between monastic and lay piety. The use of the Hours of the Virgin, rather than the full canonical Hours, was a feature of the devotional life in extra-monastic religious communities from the thirteenth century. Statutes for beguine communities and penitent confraternities, both organizations that were lay rather than monastic, tended to recommend the use of the Hours of the Virgin, suggesting a recognition of the 'devotional needs' of their members, who would not have been literati, in the strict sense of being educated in Latin. ${ }^{42}$ According to Ancrene Wisse, a Pater Noster and Ave Maria were to be said before and after each hour; the same prescription is found in the thirteenthcentury French 'riule': 'Before each hour, say one Pater Noster and one Ave Maria ... after each hour, say Pater Noster and Ave Maria for the souls who are in purgatory. 43

The Office of the Virgin also formed the basis for the Books of Hours which became the standard books for lay devotion in the later Middle Ages. In her study of the relationship between the devotional routine set out in Ancrene Wisse and the history of the Book of Hours, Millett concludes that '[Ancrene Wisse] anticipates in some detail the devotional routine of the later Books of Hours produced for a lay readership'. ${ }^{44}$ Originally added to Psalters, independent Books of Hours were first produced in the middle of the thirteenth century, at the same time that copies of Ancrene Wisse were being made. While many Books of Hours were lavishly illustrated and expensively produced, smaller, more modest copies were also made. ${ }^{45}$ The illustrations for the Office in a Book of Hours tended to depict scenes from the life of Christ, especially the Nativity and Passion, ${ }^{46}$ suggesting the popularity of these stories in lay piety, illustrating as they do the humanity of Christ. The text of the Hours would be in Latin, but there may be rubrics or directions in the vernacular, as in the early fourteenth-century Book of Hours of Alice de Reydon, which has rubrics in French. ${ }^{47}$ Alice must have known the Latin words, but the French helped her to find her way around the Book; it is difficult to say to what extent she was literate in Latin. 
How many people were literate is difficult to assess; in modern thinking, 'literacy' implies a minimum ability to understand the written word, while in the Middle Ages litteratus implied a high level of education and the ability to read and understand Latin. Literacy was associated with the Church, and it was axiomatic that lay people, laici, were illitterati whether or not they could read. Michael Clanchy sees this as evidence of a different way of thinking about literacy in the Middle Ages: 'When explaining medieval ways of thought it is correct to say that all laymen were considered illiterate, yet it would be mistaken to conclude from that proposition that in any particular time or place all nonchurchmen were unable to read or write. ${ }^{38}$ By 1300 , the preeminence of Latin as the written language of education and instruction was being challenged. The presence of Ancrene Wisse, written in English in the first half of the thirteenth century for women who were members of the gentry, is itself evidence of this important shift towards a new form of literacy and, with it, a potential challenge to the hegemony of the Church's teaching. Bella Millett suggests that, 'The lay anchoresses of the twelfth and thirteenth century seem to have been significant for the development of vernacular literature mainly because of their intermediate position between laici and clerici, illiterates and literati. ${ }^{49}$

In an article on 'The post-Conquest learning of English religious women', Alexandra Barratt has challenged the popular view that learning - especially knowledge of Latin declined significantly among English religious women in the later Middle Ages. Looking at the evidence of manuscripts owned by nuns, she concludes that 'the three sisters to whom Ancrene Wisse was addressed in the early thirteenth [century] might well, in a more structured religious community or in a different part of the country, have had a greater opportunity to learn Latin'. ${ }^{50}$ English was the appropriate language in which to write a book of guidance for lay anchoresses and, by being written in the vernacular, Ancrene Wisse was at the forefront of the dissemination of Latin pastoralia in translation for a wider readership, a movement that was to gather pace over the next two centuries. Ancrene Wisse and the works associated with it - lives of saints of the Katherine 
Group and the meditations of the Wooing Group - are themselves important evidence of devotional reading that was not confined to monasteries.

\section{Notes to Part I}

\section{The Fourth Lateran Council}

1 Caroline Walker Bynum, Jesus as Mother: Studies in the Spirituality of the High Middle Ages (Berkeley: University of California Press, 1982), pp. 9-10.

2 'Inter desiderabilia cordis nostri duo in hoc saeculo principaliter affectamus, ut . . . reformationem universalis Ecclesiae', Innocent III, 'Vineam domini sabaoth', PL 216.824 A.

3 C. H. Lawrence, The Friars: The Impact of the Mendicant Movement on Western Society (London: Longman, 1994), pp. 1-3, quotation from p. 3.

4 Colin Platt, The English Medieval Town (London: Granada, 1976; Paladin pbk. edn, 1979), p. 19.

5 Giles Constable, The Reformation of the Twelfth Century (Cambridge: Cambridge University Press, 1996; pbk edn, 1998), p. 157.

6 Herbert Grundmann, Religious Movements in the Middle Ages: The Historical Links between Heresy, the Mendicant Orders, and the Women's Religious Movement in the Twelfth and Thirteenth Centuries, trans. Steven Rowan (Notre Dame: University of Notre Dame Press, 1995), p. 25.

7 'Profession de foi de Valdes' and 'Liber antiheresis', in Enchiridion Fontium Valdensium, ed. Giovanni Gonnet (Torre Pellice: Libreria Editrice Claudiana, 1958).

8 Council of Verona, ibid, p. 51.

9 Grundmann, Religious Movements, p. 60.

10 Lawrence, Friars, pp. 22-3.

11 Colin Morris, Papal Monarachy: The Western Church from 1050 to 1250 (Oxford: Clarendon Press, 1989; Clarendon pbk, 1991), p. 350.

12 Concilium Lateranense IV, in Conciliorum Oecumenicorum Decreta, ed. J. Alberigo et al., 3rd edn (Bologna: Istituto per le Scienze Religiose, 1973), pp. 234-5 ; hereafter, Con. Lat. IV.

13 'Episcopi viros idoneos ad sanctae praedicationis officium salubriter exequendum assumant... Unde precipimus tam in cathedralibus quam in aliis conventualibus ecclesiis viros idoneos 
ordinari ... non solum in praedicationis officio verum etiam in audiendis confessionibus et poemitentiis iniungendis ac caeteris, quae ad salutem pertinent animarum.' Ibid., Con. 10, pp. 239-240; trans. Norman Tanner in Decrees of the Ecumenical Councils, ed. Norman P. Tanner (London: Sheed and Ward, 1990), vol. 1, and at www.piar.hu/councils/ecum12.htm.

14 Robert Courson, Summa ed. V. L. Kennedy, 'Robert Courson on Penance', Mediaeval Studies, 7 (1945), 291-336 (294); Kennedy points out that this quotation 'is not found in Gregory's works', n. 3. Leonard Boyle suggests that it is parochial clergy who are 'hammering at the gates of theology', 'The Fourth Lateran Council and manuals of popular theology' in Thomas J. Heffernan (ed.), The Popular Literature of Medieval England, (Knoxville: University of Tennessee Press, 1985), pp. 30-43 (p. 33).

15 'Parvuli petierunt panem, et non erat qui frageret eis.' His verbis conqueritur Jeremias in Threnis IV de defectu doctrinae et instructionis, quae valde necessaria est pueris et adolescentibus, qui habiles sunt et idonei ad suscipiendam doctrinae eruditionem, sicut cera mollis et tenera facile suscipit sigilli impressionem. Sed pauci sunt aut nulli, qui praedicent illis et frangant eis panem doctrinae; et ideo sicut corpus deficiente pane materiali deficit, ita animae parvulorum ex defectu panis spiritualis languent et arescunt.' James of Vitry, Sermo 73, 'Ad pueros et adolescentes', in Analecta Spicilegii Solesmensis, Altera Continuatio, vol. 2, ed. Pitra, (Typis Tusculanis, 1888), p. 439; trans. John Shinners, Medieval Popular Religion, 1000-1500: A Reader (Peterborough, Ontario: Broadview Press, 1997), p. 29.

16 Morris, The Papal Monarchy, p. 178.

17 Constitutio 21, 'De confessione facienda en non revelanda a sacerdote et saltem in pascha communicando', Con. Lat. IV, p. 245.

18 James of Vitry, Sermo 73, ed. Pitra, p. 440.

19 Con. Lat. IV, p. 245.

20 Robert Courson, Summa, Cap. 12.c, in Kennedy, 'Robert Courson on Penance', 326.

21 Peter Abelard's Ethics, ed. and trans. D. E. Luscombe (Oxford: Clarendon Press, 1971), p. 24, trans. p. 25; see also Michael Haren, Medieval Thought: The Western Intellectual Tradition from Antiquity to the Thirteenth Century (Basingstoke: Macmillan, 1985), p. 107, and D. E. Luscombe, 'Peter Abelard', in Peter Dronke (ed.), A History of Twelfth-Century Western Philosophy, pp. 279-307.

22 Luscombe, 'Peter Abelard', p. 305. 
23 'Recordabatur namque quos impetus cogitacionum quam ignotos carnis sue stimulos sustinuerat nec audebat se profiteri de tantis procellis integram evasisse . et si nusquam meminerit se neque actu neque voluntate lapsam fuisse', The Life of Christina of Markyate: A Twelfth Century Recluse, ed. and trans. C. H. Talbot (Oxford: Clarendon Press, 1959), pp. 126-7.

24 C. J. Holdsworth, 'Christina of Markyate', in Derek Baker (ed.), Medieval Women (Oxford: Blackwell, 1978), pp. 185-204 (p. 198), n. 71.

25 De put is hire feire neb, hire hwite swire, hire lichte echnen, hire hond, zef ha halt ford in his echze-sihðe' $A W$ Cleopatra, fo. $24^{r}$ 8-10 (this passage occurs in folios that are lost from the Corpus Christi MS and is supplied from Cleopatra, see Ancrenne Wisse, ed. Millett).

26 Boyle, 'Fourth Lateran Council', pp. 33, 34.

27 Morris, The Papal Monarchy, p. 372.

28 'Sermo M. Roberti de Sorbona ad Theologos', in César Égasse du Boulay (ed.), Historia Universitatis Parisiensis, 6 vols. (Paris, 1665-73), vol. 3, p. 232.

29 ' $\mathrm{Ne}$ nimia religionum diversitas gravem in ecclesia Dei confusionem inducat', 'regulam et institutionem accipiat de religionibus approbatis', Con. Lat. IV, p. 242.

30 'Iseon ant helpen widewen ant federlese children, ant from pe world witen him cleane ant unwemmet', $A W$ Corpus Christi, fo. $3^{\text {a }} 11-13$.

31 Peter Biller, 'Words and the medieval notion of "Religion", Journal of Ecclesiastical History, 36 (1985), 351-69; cf. Bella Millett, 'Ancrene Wisse and the life of perfection', Leeds Studies in English, 33 (2002), 53-76 (59).

32 'More than other religious', $A W$ Corpus Christi, fo. 3a17-18.

33 Constable, Reformation, p. 8.

34 James of Vitry, Historia occidentalis, ed. John F. Hinnebusch, Spicilegium Friburgense vol. 17 (Fribourg: University Press, 1972), pp. 165-6.

35 AW Corpus Christi, fo. $69^{a} 13-f .69^{b} 11$. Millett suggests that the word cuuent used here has the sense of 'a company of men or women bound together by monastic or canonical rule under one superior', attested to by Middle English Dictionary, ed. Hans Kurath (Ann Arbor, MI: University of Michigan Press, 1954- ); hereafter MED.

36 Libellus de diversis ordinibus et professionibus qui sunt in cecclesia, ed. and trans. G. Constable and B. Smith (Oxford: Clarendon Press, 1972).

37 Con. Lat. IV, p. 241; and see Constable, Reformation, p. 174. 
38 Jordan of Saxony, On the Beginnings of the Order of Preachers ed. and trans. Simon Tugwell, Dominican Sources: New Editions in English (Dublin: Dominican Publications, 1982), pp. 4-6.

39 Lawrence, Friars, p. 1; and cf. Introduction to Simon Tugwell (ed.), Early Dominicans: Selected Writings (Mahwah: Paulist Press, 1982), pp. 1-35.

40 AW Corpus Christi, fo. $16^{\mathrm{v}}$.

41 Jessalyn Bird, 'The religious's role in a post-Fourth-Lateran world: Jacques de Vitry's Sermones ad status and Historia occidentalis' in Carolyn Muessig (ed.), Medieval Monastic Preaching (Leiden: Brill, 1998), p. 222.

42 Mary O'Carroll, A Thirteenth-Century Preacher's Handbook: Studies in MS Laud Misc. 511 (Toronto: Pontifical Institute of Medieval Studies, 1997), pp. 14, 17.

\section{Eucharistic theology}

1 'Cuius corpus et sanguis in sacramento altaris sub speciebus panis et vini veraciter continentur, transsubstantiatis pane in corpus et vino in sanguinem potestate divine, ut ad perficiendum mysterium unitatis accipiamus ipsi de suo', Con. Lat. IV, p. 230; trans. Tanner.

2 Joseph Goering suggests that Robert Pullen was the first to use the term transubstantiation in Paris around 1140, 'The invention of transubstantiation', Traditio, 46 (1991), 147-70 (158).

3 'Manibus sacerdotum tractari, vel frangi, vel fideliulm dentibus atteri', 'Jusjurandum quod in eadem synodo fecit Berengarius', in Sacrorum Conciliorum Nova, ed. J. D. Mansi (Venice, 1774), vol. 19 , col. 900 .

4 Gary Macy, The Theologies of the Eucharist in the Early Scholastic Period: A Study of the Salvific Function of the Sacrament according to the Theologians c.1080-c.1220 (Oxford: Clarendon Press, 1984), p. 36.

5 Henry Bettenson (ed.), Documents of the Christian Church (London: Oxford University Press, 1943), p. 207.

6 Eamon Duffy, The Stripping of the Altars: Traditional Religion in England c.1400-c.1580 (New Haven: Yale University Press, 1992), p. 110.

7 'Quantum debet esse sanctus, isutus et dignus qui [Christum] ... contrectat manibus, corde et ore sumit et aliis ad sumendum praebet?' Francis of Assisi, 'Epistola II', in Opuscula Sancti Patris Francisci Assisiensis, ed. PP. Collegii S. Bonaventurae (Quaracchi: Collegium S. Bonaventurae, 1904), pp. 102-3; 
trans. Caroline Walker Bynum, Holy Feast and Holy Fast: The Religious Significance of Food to Medieval Women (Berkeley: University of California Press, 1987), p. 57.

8 'Praecipitur presbyteris ut cum in canone inceperint qui pridie tenentes hostiam ne elevent eam statim nimis alte, ita quod possit videri a populo sed quas ante pectus detineant donec dixerint Hoc est corpus meum et tunc elevent eam ita quod possit videri ab omnibus', quoted from Paris BN MS. Lat. 14.443, fo. 291 and trans. V. L. Kennedy, 'The moment of consecration and the elevation of the Host', Mediaeval Studies, 6 (1944), 21-50 (122).

9 Joseph Jungmann, with reference to a London synod of 1215, The Mass of the Roman Rite: Its Origins and Development, trans. Francis A. Brunner, 2 vols. ([1955] Westminster, Maryland: Christian Classics, 1986), vol. 2, p. 206.

10 Miri Rubin, Corpus Christi: The Eucharist in Late Medieval Culture (Cambridge: Cambridge University Press, 1991), pp. 53-4.

11 AW Corpus Christi, fo. $8^{\text {a }}, 19$.

12 Ibid, fo. $8^{\text {a }} 19$.

13 'Ecce salus mundi, uerbum Patris, hostia uera, Viua caro, Deitas integra, uerus homo', Ibid, fo. $8^{\text {a }} 20-1$; trans. Millett.

14 C. H. Talbot, 'Some notes on the dating of the Ancrene Riwle', Neophilologus, 40 (1956), 38-50(49).

15 Rubin, Corpus Christi, p. 58.

16 'Quaedam autem tanto desiderio post odorem tanti sacramenti currebant, quod nullo modo eo diu carere sustinebant', James of Vitry, Prologue to Vita Mariae Oigniacensis, in Acta Sanctorum June, vol. 4, ed. D. Papebrochius (Antwerp, 1707), \$ 8, p. 638 (hereafter, VMO); Jacques de Vitry, The Life of Marie d'Oignies, trans. Margot H. King, Peregrina Papers Series, 3 (Toronto: Peregrina, 1993), p. 41. see Song of Songs 1: 3.

17 'Solum caelestum sponsum desiderarent', VMO, $\mathbb{S} 2$, p. 636.

18 Gertrude of Helfta, Oeuvres Spirituelles, vol. 3, Le Herault, Book 3, ed. and trans. Pierre Doyere, Sources Chrétiennes No. 143 (Paris: Éditions du Cerf, 1968), p. 80 ; Gertrude of Helfta, The Herald of Divine Love, trans. Margaret Winkworth, Classics of Western Spirituality (Mahwah, NJ: Paulist Press, 1993), p. 175.

19 Elizabeth A. Andersen, Mechthild of Magdeburg: Selections from The Flowing Light of the Godhead, Library of Medieval Women (Cambridge: Brewer, 2003), I.22, p. 31; cf. Mechthild von Magdeburg, Flowing Light of the Divinity, trans. Christiane Mesch Galvani, Garland Library of Medieval Literature, Series B, vol. 72 (New York: Garland Publishing, 1991), p. 14. 
20 Andersen, Mechthild, III.15, p. 61; and see Macy, Theologies of the Eucharist, pp. 89-90.

21 Andersen, Mechthild, VII.21, p. 128.

22 Ibid., II.4, p. 42.

23 Anneke B. Mulder-Bakker, Lives of the Anchoresses; The Rise of the Urban Recluse in Medieval Europe, trans. Myra Heerspink Scholz (Philadelphia: University of Pennsylvania Press, 2005), pp. 86-7.

24 Bynum, Fragmentation and Redemption, p. 129.

25 Macy, Theologies of the Eucharist, p. 89.

26 'Crucem tollebat, corpus suum per abstinentiam castigando; Christum imitabatur, seipsam per humilitatem abjiciendo', $V M O, \mathbb{S} 21$, p. 641; trans. King p. 54.

27 AW Corpus Christi, fo. 95 22 -fo. 96 23.

28 'Sane ad affectuosum, quem dicimus, cordis amorem plurimum valet cogitatio incarnationis Christi, sed et totius dispensationis quam gessit in carne, et maxime passionis.' Bernard of Clairvaux, Sermo 29, 'De Diversis', in Sancti Bernardi Opera, vol. 6.i, ed. J. Leclercq and H. Rochais (Rome: Editiones Cistercienses, 1970), p. 211; trans. Constable, Reformation, p. 284.

29 Ernest W. McDowell, The Beguines and Beghards in Medieval Culture with Special Emphasis on the Belgian Scene (New Brunswick, NJ: Rutgers University Press, 1954), p. 131.

30 Bynum, Fragmentation and Redemption, p. 127.

\section{Anchorites and beguines}

1 Bynum, Holy Feast, pp. 20-2; though Elkins holds that the significance of virginity for religious women lay in its pragmatic value, as a 'guarantee of freedom', rather than its 'spiritual qualities', Sharon K. Elkins, Holy Women of Twelfth Century England (Chapel Hill: North Carolina Press, 1988), p. 29.

2 Bruce Venarde, Women's Monasticism and Medieval Society: Nunneries in France and England, 890-1215 (Ithaca: Cornell University Press, 1997), p. 13.

3 Bynum, Holy Feast, p. 15.

4 'Cum femina semper esse, et non cognoscere feminam, nonne plus est quam mortuum suscitare?', Bernard of Clairvaux, Sermones in Cantica, 65.4, in S. Bernardi Opera, vol. 2, ed. J. Leclercq, C. H. Talbot and H. M. Rochais (Rome: Editiones Cistercienses, 1958), p. 175; Bernard of Clairvaux, On the Song of Songs, 3, trans. Kilian Walsh and Irene M. Edmonds (Kalamazoo, MI: Cistercian Publications, 1979), p. 184. 
5 Grundmann, Religious Movements, p. 242, and Morris, Papal Monarchy, p. 468.

6 Grundmann, Religious Movements, p. 76.

7 'Licet parentes earum multis divitiis abundarent. Ipsae tamen obliviscentes populum suum et domum patris sui, malebant angustias et paupertatem sustinere, quam male acquisitis divitis abundare, vel inter poposos seculares cum periculo remanere', James of Vitry, VMO, p. 636; and see Life, trans. King, p. 37.

8 James of Vitry, Sermone 33, 'Ad heremitas, solitarios et inclusos', in Analecta Novissima Specilegii Solesmensis, vol. 2, Tusculana, ed. Pitra (Typis Tusculanis, 1888; repr. 1967), p. 397.

9 Giles Constable, 'Aelred of Rievaulx and the Nun of Watton: an episode in the early history of the Gilbertine Order', in Medieval Women, ed. by Derek Baker (Oxford: Blackwell, 1978), pp. 205-26 (p. 207).

10 The story didn't end so happily for the man; ibid., p. 208.

11 Elkins, Holy Women, p. 107.

12 Sally Thompson highlights the difficulty of sorting out exactly what happened in the suppression of double monasteries; sometimes when women were housed separately they were still regarded as members of the same community. In 1270, more decisive measures were taken for the suppression of nuns. Sally Thompson, Women Religious: The Founding of English Nunneries after the Norman Conquest (Oxford: Clarendon Press, 1991), pp. 138-9.

13 C. H. Lawrence, Medieval Monasticism (London: Longman, 1984), p. 181.

14 Venarde, Women's Monasticism, pp. 7-9, esp. fig. 2, p. 8.

15 Ibid., Women's Monasticism, p. xiii.

16 R. W. Southern, Western Society and the Church in the Middle Ages (London: Hodder and Stoughton, 1970), p. 315.

17 McDowell, Beguines and Beghards, p. 113.

18 Dennis Devlin, 'Feminine lay piety in the high Middle Ages: the beguines', in John A. Nicholls and Lillian Thomas Shank (eds), Distant Echoes: Medieval Religious Women, vol. 1 (Kalamazoo, MI: Cistercian Publications, 1984), pp. 183-96 (p. 185).

19 John Coakley, 'Friars as confidents of holy women in medieval Dominican hagiography', in Renate Blumenfeld-Kosinski and Timea Szell (eds), Images of Sainthood in Medieval Europe (Ithaca: Cornell University Press, 1991), pp. 222-46.

20 Grundmann, Religious Movements, p. 83.

21 Elizabeth Freeman, University of Tasmania, pers.comm.; and cf. Elizabeth Freeman, 'Male and female Cistercians and their gendered experiences of the margins, the wilderness and the 
periphery', in Liz Herbert McAvoy and Mari Hughes-Edwards (eds), Anchorites, Wombs and Tombs: Intersections of Gender and Enclosure in the Middle Ages, (Cardiff: University of Wales Press, 2005), pp. 65-76 (p. 71).

22 Mulder-Bakker, Lives of the Anchoresses. Mulder-Bakker draws distinctions between inclusa and reclusa, but admits that it should be noted that no matter how clear the conceptual distinctions introduced here may seem in the abstract, medieval authors often failed to discriminate between them in concrete usage', Lives of the Anchoresses, p. 6. The problem may not be the medieval authors' failure to discriminate so much as the compulsion of modern authors to seek discrimination and categorization.

23 'Eisdemque temporibus, quidam, in Alemannia præcipue, se asserentes religiosos, in utroque sexus, sed maxime in muliebri, habitum religionis, sed levem, susceperunt, continentiam et vitæ simplicitatem privato voto profitentes, sub nullius tamen sancti regula coarctatæ, nec adhuc ullo claustro contenti. Earumque numerus in brevi adeo multiplicabatur, ut in civitate Coloniæ et partibus adjacentibus duo milia invenirentur.' Matthew Paris, entry for 1243, in Chronica Majora, vol. 4, ed. Henry Richards Luard, in The Chronicles and Memorials of Great Britain and Ireland during the Middle Ages (Rolls Series), ([1877] Wiesbaden: Kraus repr., 1964); trans. Southern, Western Society, p. 319.

24 Matthew Paris, Historia Anglorum, vol. 2, ed. Sir Frederic Madden (Rolls Series, 1866; Wiesbaden: Kraus repr., 1971), p. 476.

25 'Beguinae sunt perfectissimae et sanctissimae religionis, quia vivunt propriis laboribus et non onerant exactionibus mundum', Thomas of Eccleston, Tractatus de Adventu Fratrum Minorum in Angliam, ed. A. G. Little (Manchester: Manchester University Press, 1951), p. 99.

26 Grundmann, Religious Movements, p. 147.

27 W. Simons, 'The beguine movement in the southern Low Countries; a reassessment', Bulletin de l'institute historique Belge de Rome, 59 (1989), 63-101. Available at http://matrix. divinity.yale.edu/MatrixWebData/Simonsc.txt, p. 76.

28 Richard Barber, Penguin Guide to Medieval Europe (London: Penguin, 1984), pp. 308, 311-12.

29 Cf. Simons, 'The beguine movement', p. 71; Brenda M. Bolton, 'Mulieres sanctae', in Susan Mosher Stuard (ed.), Women in Medieval Society, (Philadelphia: University of Pennsylvania Press, 1976), pp. 141-58 (p. 147); McDowell, Beguines and Beghards, pp. 83-4; and see also Venarde, Women's Monasticism, pp. 92-3, 


\section{NOTES TO PART I}

who suggests a similar imbalance of men and women in the eleventh and twelfth centuries.

Grundmann, Religious Movements, p. 140.

R. Hoornaert, 'La plus ancienne Règle de Béguinage de Bruges', Annales de la société d'émulation de Bruges, 72 (1929), 1-79 (26).

32 Ibid., pp. 43-9.

33 Simons, 'The beguine movement', p. 90.

34 Brenda M. Bolton, 'Some thirteenth-century women in the Low Countries: a special case?', Nederlands Archief voor Kerkgeschiedenis, 61 (1981), 7-29 (10).

35 McDowell, Beguines and Beghards, p. 88.

36 'Rien n'est plus faux. La charte de 1245 nous montre au contraire, à la Vinea de Bruges, des âmes s'orientant nettement vers une vie de haute contemplation et désireuses de mener une vie d'oraison méthodique à l'abri du monde.' Hoornaert, 'Ancienne Règle', p. 5.

37 Penny Galloway, 'Neither miraculous nor astonishing: the devotional practice of beguine communities in French Flanders', in Juliette Dor, Lesley Johnson and Jocelyn Wogan-Browne (eds), New Trends in Feminine Spirituality: The Holy Women of Liège and their Impact, Medieval Women: Texts and Contexts, 2 (Turnhout: Brepols, 1999), pp. 107-27 (p. 107). James of Vitry, VMO, p. 639 ff; Life, trans. King, p. 47. James of Vitry, VMO, p. 641.

39 'Fervore enim spiritus quasi inebriata, prae dulcedine Agni paschalis carnes suas fastidiens; frustra non modica cum cultello rescavit, quae prae verecundia in terra abscondit', ibid.; trans. King, p. 54; verecundia, translated by $\mathrm{King}$ as a sense of reticence, can also mean shame.

40 The daily devotions to be observed by the anchoresses are in Part One of Ancrene Wisse; the regulations for the Beguinage of Bruges also prescribe daily devotions, Hoornaert, 'Ancienne Règle', pp. 53-7.

41 Robert W. Ackerman, 'The liturgical day in Ancrene Riwle', Speculum, 53 (1978), 734-44 (738).

42 Roger Dahood, 'Design in Part 1 of Ancrene Riwle', Medium Aevum, 56 (1987), 1-11, (3).

43 Anne Savage and Nicholas Watson point out that the 'nonofficial devotions' occupy the mid-morning, 'from Prime to the end of mass', Anchoritic Spirituality, p. 344; and Dahood points out that, 'The scheduling of such additional prayers between prime and terce [i.e. early to mid-morning] has precedent in monastic observance', 'Design', p. 3. 
44 Ackerman, 'Liturgical day', p. 738.

45 Hoornaert, 'Ancienne Règle', p. 8.

46 'Elke meestrigghe sal hare wroghen vier warven sjaers in hare capitele vor die grote meestrigghe ende hare kindre', 'Chaque Maîtresse fera sa coulpe quatre fois l'an en son chapitre devant la Grande Maîtresse et ses filles', Hoornaert, 'Ancienne Règle', p. 43; thanks to Janet Potterton for helping me with understanding the Dutch and French here.

47 MS Bibliothèque de l'Arsenal, Paris, 2058, fo. 60 - fo. $65^{\mathrm{v}}$. See M. Zink, La Prédication en langue romane avant 1300 (Paris, 1976), p. 161, for the 'problème particuliere' of this text.

48 Bella Millett, 'The genre of Ancrene Wisse', in Companion, pp. 29-44 (pp. 29, 42).

49 At times it seems to use the masculine to address its readers.

50 MS Ars. 2058, fo. 62 ${ }^{\mathrm{r} 2}$. For further discussion of this text see Cate Gunn, 'Private meditations and public discourse: Ancrene Wissse and Sermon Rhetoric', in McAvoy (ed.), Rhetoric of the Anchorhold.

51 Ann K. Warren, Anchorites and Their Patrons in Medieval England (Berkeley: University of California Press, 1985), pp. 20-1.

52 'Sustren of one ueder J of one moder. i ne blostme of ower zuweðe uorheten alle wor[l]des blissen: J bicomen ancren', AW Nero, fo. $50^{\mathrm{r}}$, p. $85,8-27$.

53 The Rule of Benedict: A Guide to Christian Living (Latin text established by $\mathrm{H}$. Rochais and E. Manning), trans. monks of Glenstal Abbey, with commentary by George Holzhar (Dublin: Four Courts Press, 1994), pp. 41, 42.

54 AW Corpus Christi, fo. 99 16.

55 'Certe si praeter necessarium uictum et uestitum aliquid habes, monacha non es', Aelred of Rievaulx, De Institutione Inclusarum, in Opera Omnia, ed. A. Hoste and C. H. Talbot, CCCM, 1 (Turnhout: Brepols, 1971), $\mathbb{S}$ 4, p. 639, hereafter, DII; 'Rule of Life for a Recluse' trans. Mary Paul Macpherson, in Treatises; The Pastoral Prayer, Cistercian Fathers Series, 2 (Kalamazoo: Cistercian Publications, 1971), p. 48. Mari Hughes-Edwards points out in her Ph.D. thesis for York University that this is the only evidence we have for the assertion that Aelred's sister was a nun; I am grateful to her for allowing me to see this part of her thesis prior to its completion and submission.

56 'Primum igitur oportet te scire qua causa, quare ratione huiusmodi uita $a b$ antiquis uel instituta sit uel usurpata ... Itaque antiqui [uel ut . . uel ne . . uel ut . . .] singulariter uiuere delegerunt.' Aelred, DII, $\mathbb{S} 2$, p. 637; trans. 'Rule of Life', p. 45. 
57 'Only two of the one hundred and twenty-three female anchorites known for the thirteenth century can with confidence be counted as former nuns', Warren, Anchorites and their Patrons, p. 25.

'Me let lesse deinte to pinge pet me haued ofte. and for pi ne schule ze beon bute ase ure leawude brepren beoð: i huse-led wiðinnen tweolf moneð : bute viftene siðen', $A W$ Nero, p. 188, $1-4$.

60 This would, Millett believes, make them 'technically religious according to canon law'; see 'Life of perfection', pp. 6-8.

61 Barratt, 'Small Latin?' p. 65.

62 Dobson follows Tolkien in using linguistic evidence to place the author of Ancrene Wisse on the Herefordshire/Shropshire borders. E. J. Dobson, 'The date and composition of Ancrene Wisse', in Proceedings of the British Academy, 52, 1966 (London: pub. for the British Academy by Oxford University Press, 1967), pp. 181-208.

63 Victoria County History: Shropshire, vol. 2, p. 83.

64 R. H. Hilton, A Medieval Society: The West Midlands at the End of the Thirteenth Century (London: Weidenfeld and Nicolson, 1966), p. 26.

65 Ann K. Warren, 'The nun as anchoress: England 1100-1500', in Nicholls and Shank (ed.), Distant Echoes, pp. 197-212 (pp. 203-4).

66 Warren, Anchorites and Their Patrons, p. 16.

\section{Anchoritic spirituality}

1 AW Corpus Christi, fo. 69a 14.

2 Simon Tugwell, The Way of the Preacher (London: Darton, Longman and Todd, 1979), pp. 114-15.

3 The term is Colin Morris's in Papal Monarchy, p. 366.

4 Bynum, Fragmentation and Redemption, p. 146.

5 Pierre-Marie Gy, 'Liturgy and spirituality ii: sacraments and liturgy in Latin Christianity', trans. Craig McKee, in Bernard McGinn and John Meyendorff (eds), Christian Spirituality I: Origins to the Twelfth Century, World Spirituality: An Encyclopedic History of the Religious Quest, vol. 16 (London: Routledge and Kegan Paul, 1986), pp. 365-82 (p. 379).

6 'De neauer ne beoð gleade iheortet bute hwen ha polieð sum wa oðer scheome wið Iesu on his rode', $A W$ Corpus Christi, fo. $95^{\text {b }}$ $19-21$. 
7 Mary Baldwin, 'Ancrene Wisse and its background in the Christian tradition of religious instruction and spirituality' (unpub. doctoral thesis, University of Toronto, 1974), p. 44.

8 The anchoresses keep themselves 'from pe worlt ouer opre religiuse cleane ant unwemmet', $A W$ Corpus Christi, fo. $3^{\text {a }} 26-7$.

9 'Creop in ham wið pi poht - ne beoð ha al opene? - and wið deorewurðe blod biblodge pin heorte.' Ibid., fo. 79b 12-14.

10 Warren, Anchorites and Their Patrons, p. 93.

11 'Alswa as na mon ne luueð lomen for ham seolf, ah deð for pe pinges pet me wurcheð wið ham, alswa na flesches derf nis to luuien bute for-pi, pet Godd te reaðere piderward lokeð mid his grace, ant makeð pe heorte schir ant of briht sihðe.' AW Corpus Christi, fo. 104a $19-23$.

12 Jacques le Goff, The Medieval Imagination, trans. Arthur Goldhammer (Chicago: University of Chicago Press, 1988; pbk edn, 1992), pp. 85, 91.

13 ' 3 ef ze penne I nearow stude polieð bitternesse, ze beoð his feolahes, reclus as he wes I Marie wombe. Beo ze ibunden inwið fowr large wahes? Ant he, in a nearow cader, ineilet o rode, I stanene pruh bicluset hetefeste. Marie wombe ant pis pruh weren his ancre-huses.' AW Corpus Christi, fo. 102 28 -fo. $102^{\mathrm{b}} 5$.

14 Augustine, Confessions, Bks 1, 2 and 5, trans. R. S. Pine-Coffin (London: Penguin, 1961), pp. 22, 24; Millett notes that 'Tibi' $\left(1.8^{\mathrm{v} / 3}\right)$ is not in Augustine's text.

15 'Angusta est tibi domus anime mee, quo uenias ad eam; dilatetur abs te', $A W$ Corpus Christi, fo. $8^{\mathrm{b}} 3-4$.

16 Ibid., fo. $8^{\mathrm{b}} 20-1$; this section is described at greater length below.

17 ' 3 e beoð wið Iesu Crist bitund as i sepulcre, bibarret as he wes o pe deore Rode.' Ibid., fo. $45^{\mathrm{b}}$ 21-3.

18 'Al hare blisse is forte beon ahonget sariliche any scheomeliche wið Iesu on his rode.' Ibid., fo. 95 $24-6$.

19 Jocelyn Wogan-Browne, Saints' Lives and Women's Literary Culture c.1150-1300: Virginity and its Authorizations (Oxford: Oxford University Press, 2001), pp. 130-1.

20 Aelred of Rievaulx, De Institutione Inclusarum: Two English Versions, ed. John Ayto and Alexandra Barratt, EETS (London: Oxford University Press, 1984), p. xxxix.

21 ' 3 ef we libbeð i scheome ant i pine for his luue, i hwucche twa he deide, we schulen beon liche his blisful ariste, ure bodi briht as his is, world buten ende', $A W$ Corpus Christi, fo. 97b 2-4.

22 'Swiftnesse ant leome of a briht sihðe', ibid., fo. $24^{\mathrm{b}} 18$.

23 Savage and Watson, Anchoritic Spirituality, n. 127, p. 385. 
24 John Morson, Christ the Way: The Christology of Guerric of Igny, Cistercian Studies, 25 (Kalamazoo, MI: Cistercian Publications, 1978), p. 129.

25 Bernard of Clairvaux, Sermones in Cantica, 61.3, in Opera, vol. 1, pp. 149-50; On the Song of Songs 3, p. 142.

26 Guerric of Igny, Liturgical Sermons, vol. 2, trans. monks of Mount St Bernard Abbey, Cistercian Authors Series, 32 (Spencer, MA: Cistercian Publications, 1971), pp. 73-8. I am grateful to Sheryl Frances Shen, who gave a paper on 'Guerric's sermons for Palm Sunday: imitatio Christi and entrance into the wounds' at the 36th International Congress on Medieval Studies, Kalamazoo, Michigan, 5 May 2001, for this reference.

27 Savage and Watson, Anchoritic Spirituality, p. 385, n. 127.

28 'As in uncuð lond ant in uncuð eard bituhhen unpeode', $A W$ Corpus Christi, fo. 97a 3-4.

29 Introduction to Bella Millett and Jocelyn Wogan-Browne (eds), Medieval English Prose for Women: Selections from the Katherine Group and Ancrene Wisse, (Oxford: Clarendon Press, rev. edn, 1992), p xliii.

30 Ibid., pp. 10, 11.

31 James of Vitry, VMO, p. 661; The Life of Marie d'Oignies, p. 42.

32 'Dis mihte is pet an pet $\mathrm{i}$ pis deadliche lif schaweð in hire an estat of pe blisse undeadlich i pet eadi lond as brude ne nimeð gume ne brudgume brude; ant teacheð her on eorðe in hire liflade pe liflade of heouene', Medieval English Prose for Women, p. 10; trans. p. 11.

33 'Passer solitarius', AW Corpus Christi, fo. 41 15 15-17.

34 'For hwa-se is muche stille, ant halt silence longe, ha mei hopien sikerliche pet, hwen ha spekeð toward Godd, pet he hire ihere; ha mei ec hopien pet ha schal singen, purh hire silence, sweteliche in heouene', ibid., fo. 20a 16-20.

35 'Sola sedeat et taceat ore, ut spiritu loquatur, et credat se non esse solam, quando sola est. Tunc enim cum Christo est, qui non dignatur in turbis esse cum ea', Aelred, DII, p. 641; 'Rule of life', p. 50.

36 'Ponat custodiam ori suo', Aelred, DII, p. 641; 'Rule of life', p. 50.

37 AW Corpus Christi, fo. $12^{\mathrm{b}} 4-5$.

38 Ibid., fo. 8a 19.

39 See Introduction to Lay-Folks' Mass-Book, ed. Thomas Frederick Simmons, EETS, o.s., 71 (London: Trubner, 1879), p. xviii. The Lay-Folks' Mass-Book is a volume compiled from English manuscripts dating from about 1375 , but purporting to be translations. The editor assumes the original was in French 
(pp. xxxii-xxxiii), and uses internal evidence to suggest a date for the original of the mid twelfth century (p. xxxvi).

40 Cate Gunn, "Efter the Measse-Coss, Hwen the Preost Sacreð': when is the moment of ecstasy in Ancrene Wisse?', Notes and Queries, 246, n.s., 48 (2001), 105-8 (107-8).

41 'Quotidie pro omnibus', quoted in Jungmann, Mass of the Roman Rite, pp. 364-5; cf. Bynum, Holy Feast and Holy Fast, p. 57.

42 AW Corpus Christi, fo. $111^{\text {a }} 25$.

43 'Tale corpus Christi credo, teneo, amplector, sumo, in uisceribus interioris mei traicio', Libellus de Diversis Ordinibus, ed. Constable and Smith, pp. 70, 71.

44 'His omnibus 'mortificationem' Christi 'in corpore suo circummferre' congruet. Aliter enim spiritum sanctum assequi non ualent', ibid., pp. 22, 23.

45 'Falleð o cneon to ower crucifix wið peose fif gretunges ine munegunge of Godes fif wunden', AW Corpus Christi, fo. $5^{\text {a }}$ $13-14$.

46 'Abute middei hwa-se mei . . . penche o Godes Rode ... ant of his derue pine', ibid., fo. $8^{\mathrm{b}}$ 24-7.

47 'Pencheð o 3odes flesch ant on his deorwurðe blod, pet is abuue pe hehe weoued', ibid., fo. $5^{\text {a }} 2-3$ and fo. $5^{\text {a }} 13-14$.

48 'Brad as scheld buuen in his istrahte earmes, nearow bineoðen, as pe an fot (efter monies wene) set upo pe oðer', ibid., fo. $106^{\text {a }}$ $1-3$.

49 'Al of luue pe makeð schir herote', ibid., fo. $103^{\mathrm{b}} 28$.

50 'Seinte Pawel witneð pet alle uttre heardschipes, alle flesches pinsunges ant licomliche swinkes, al is ase nawt azeines luue', ibid., fo. $104^{\mathrm{a}} 1-5$.

51 Ibid., fo. $105^{\text {b }} 21-$ fo. $106^{\text {a }} 3$.

52 Ibid., fo. $95^{\text {b }} 22-$ fo. $96^{\text {a }} 2$.

53 ' 3 e schulen habben pruppe pe brihte sihðe of Godes neb, pet alle gleadunge is of, i pe blisse of heouene, muche biuore pe opre. For pe rihtwise Godd hit haueð swa idemet pet euchanes mede per ondswerie azein pe swinc ant azeines pe ennu pet ha her for his luue eadmodliche polieð. For-pi his is semlich pet ancren peos twa marheouen habben biuoren opre, swiftnesse ant leome of a briht sihðe azeines pet ha her peostrið nu ham seoluen, ne nulleð nowðer iseo mon ne of mon beon isehene.' Ibid., fo. 11-22. 


\section{Lay piety}

1 The feast was instituted in 1264, although it didn't achieve full popularity until after its re-promulgation in the fourteenth century. It was also in the fourteenth century that the monstrance, used for exhibiting the Host, was introduced; Bynum, Holy Feast and Holy Fast, p. 55.

2 Morris, Papal Monarchy, p. 178.

3 Constable, Reformation, p. 280.

4 Bynum, Jesus as Mother, p. 16.

5 AW Corpus Christi, fo. $8^{\mathrm{b}}$ 25-7.

6 Robert Grosseteste, Epistolae, 52, in The Chronicles and Memorials of Great Britain and Ireland during the Middle Ages, vol. 25, ed. Henry Richards Luard ([1861] Wiesbaden: Kraus reprint, 1965), p. 155.

7 Rubin, Corpus Christi, pp. 62-3.

8 Miri Rubin, 'What did the Eucharist mean to thirteenth-century villagers?' in P .R. Coss and S. D. Lloyd (eds), ThirteenthCentury England IV, Proceedings of the Newcastle upon Tyne Conference, 1991, ed. by P. R. Coss and S. D. Lloyd (Woodbridge: Boydell and Brewer, 1992), pp. 47-55.

9 Grosseteste, Epistolae, 22, p. 72.

10 Statutes of Bishop Alexander of Stavensby, in Councils and Synods with Other Documents Relating to the English Church, vol. 2, 1205-1313, ed. F. M. Powicke and C. R. Cheney (Oxford: Clarendon Press, 1964), pp. 209-11.

11 'Hoc est corpus meum' (Mark 14: 22), in the Vulgate Bible and in the Mass.

12 John Harper, The Forms and Orders of Western Liturgy from the Tenth to the Eighteenth Century (Oxford: Clarendon Press, 1991), p. 113.

13 The phrase 'cultic acts' is from Morris, Papal Monarchy, p. 299.

14 Daniel Sheerin, 'The liturgy', in F. A. C. Mantello and A. G. Rigg (eds), Medieval Latin: An Introduction and Bibliographical Guide, (Washington, DC: Catholic University of America Press, 1996), pp. 157-82 (p. 167); and see Jungmann, Mass of the Roman Rite, vol. 2, p. 214.

15 Lay-Folks Mass-Book, pp. 40-2, and see Introduction, p. xviii.

16 'We beoð alle i prisun her, any ahen Godd greate deattes of sunne. ... Who pet me deð us, oðer of word oðer of werc, pet is ure rancun pet we schule reimin us wið, ant cwitin ure deattes toward ure Lauerd, pet beoð ure sunnen; for wiðute cwitance, up of pis prisun nis nan inumen pet nis anan ahonget, oðer i Purgatoire oper i pe pine of helle.' AW Corpus Christ, fo. $34^{\text {a }} 24-$ fo. $34^{\text {b }} 2$. 
17 'Ah ic eow segge to soðe pes pu hefdest mare deruenesse on pisse liue of pine licome: pes pu scoldest hersumian pe bet pine leofe drihten and halden his bibode.' 'Hic dicendum est de quadragesima', Old English Homilies and Homiletic Treatises, First Series, ed. Richard Morris (London: Early English Text Society, 1868), p. 21; trans., p. 20.

18 Thomas Hahn, 'Early Middle English', in CHMEL, pp. 61-91 (p. 83).

19 'Dominica prima in quadragesima', Old English Homilies, ed. Morris, p. 25.

20 Morris, Papal Monarchy, pp. 371, 436-7.

21 Bella Millett, 'The pastoral context of the Lambeth and Trinity Homilies', in Wendy Scase (ed.), Vernacular Manuscript Books of the English West Midlands from the Conquest to the Sixteenth Century, (Turnhout: Brepols, forthcoming).

22 Dahood, 'Design', 3.

23 'Dis ureisun biuore pe muchele Rode is of muche strehgðe', $A W$ Corpus Christi, fo. $8^{\mathrm{b}} 23-4$. In the Notes to her forthcoming edition, Millett admits that 'the status of this rubric is disputed' but has given the A scribe 'the benefit of the doubt, and treated the sentence as a rubric which refers to what follows'; what follows is a meditation on the cross.

24 AW Corpus Christi, fo. 8 $8^{\text {a }} 19-$ fo. $8^{\text {b }} 17$.

25 Ibid., fo. 9b $11-$ fo. $10^{\mathrm{b}} 9$.

26 Morris, Papal Monarchy, p. 302.

27 Paul Binski, Becket's Crown: Art and Imagination in Gothic England 1170-1300 (New Haven: Yale University Press, 2004), p. 222; and cf. Paul Frankl, The Gothic: Literary Sources and Interpretations through Eight Centuries (Princeton, NJ: Princeton University Press, 1960), p. 828: 'On Romanesque crucifixes Jesus stands upright and alive; nailed to his cross, he is independent. On Gothic crosses he droops in weakness or death; he is dependent.'

28 T. A. Heslop, 'Attitudes to the visual arts: the evidence from written sources', in Jonathan Alexander and Paul Binski (eds), Age of Chivalry: Art in Plantagenet England, 1200-1400, (London: Weidenfeld and Nicolson for the Royal Academy of Arts, 1987), pp. 26-32 (p. 26), and Binski, Becket's Crown, pp. 202-3.

29 Duffy, Stripping of the Altars, p. 157.

30 'Abute middei hwa-se mei ... penche o Godes Rode ... ant of his derue pine', $A W$ Corpus Christi, fo. $8^{\mathrm{b}}$ 24-7.

31 Councils and Synods, ed. Powicke and Cheney, p. 57.

32 'Exhortentur sepius sacerdotes parochianos suos ad discendum simbolum et dominicam orationem et salutationem beate Marie', ibid., p. 61. 
33 Hilda Graef, Mary: A History of Doctrine and Devotion ([1963] London: Sheed and Ward, 1985), I, p. 231.

34 Rosemary Woolf, The English Religious Lyric in the Middle Ages (Oxford: Clarendon Press, 1968), pp. 116, 117.

35 AW Corpus Christi, fo. 9a $26-$ fo. $10^{\text {a }} 15$; and see Barbara Raw, 'Prayers and devotions in the Ancrene Wisse', in Beryl Rowland (ed.), Chaucer and Middle English Studies in Honour of Rossell Hope Robbins (London: George Allen and Unwin, 1974), pp. 260-71 (p. 260).

36 Anne Winston-Allen, Stories of the Rose: The Making of the Rosary in the Middle Ages (Pennsylvania: Pennsylvania State University Press, 1997), p. 7.

37 Ibid., p. 4.

38 AW Corpus Christi, fo. $12^{\text {a }} 3-6$.

39 Millett, 'Women in no man's land', p. 94.

40 Walter Hilton, The Scale of Perfection, II.42, ed. Thomas H. Bestul, Middle English Texts Series (Kalamazoo, MI: Medieval Institute Publications, 2000), p. 246.

41 Nicole Bériou, 'La Prédication au béguinage de Paris pendant l'année liturgique 1272-73', Recherches Augustiniennes, 13 (1978) 105-229, (121), with reference to MD Chapotin, Histoire des Dominicains de la Province de France: le siècle des fondations (Paris-Rouen, 1898), p. 521.

42 Millett, 'Ancrene Wisse and the Book of Hours', p. 31.

43 'Devant cascune eure dites une pater nostre et vn aue maria ... apres cascune eure. dites pater noster. et aue maria por les ames ki sunt en purgatoire', MS Ars. 2058, fo. 60 ${ }^{\mathrm{r}}$ col. a, 9-11 and $18-21$.

44 Millett, 'Ancrene Wisse and the Book of Hours', p. 13.

45 Janet Backhouse, Books of Hours (London: British Library, 1985), p. 3.

46 Ibid., p. 4.

47 Cambridge University Library MS Dd.4.17.

48 Clanchy, From Memory to Written Record, pp. 231-2.

49 Millett, 'Women in no man's land', p. 99.

50 Barratt, 'Small Latin?', p. 65. 



\section{Part II}

\section{Pastoralia and vernacular pastoral literature}





\section{6 \\ Pastoralia}

The account I have given so far of the composition of Ancrene Wisse has dealt with it as an anchoritic work, drawing on models, such as the De Institutione Inclusarum of Aelred of Rievaulx, which themselves were composed within a monastic tradition. Ancrene Wisse is, however, one of a group of religious prose works written in the vernacular intended to be read by a general lay audience, as well as by anchorites. This group includes lyrical meditations and lives of saints to be read for devotional and practical purposes. ${ }^{1}$ It has been suggested, though not proved, that all these works were by a single author; they probably originate from the same community or school, and there are some cross-references, including one in Ancrene Wisse to 'your English book of Saint Margaret'.2

The three saints' lives are all of virginal females: Katherine, Margaret and Julian; they are grouped with Hali Meiðhad, which deals specifically with the vocation of a virginal life. Sawles Warde, the fifth work in the Katherine Group, however, 'deals with a theme which is equally relevant to all Christians', and the saints' lives 'were apparently intended in the first instance for public delivery to a general audience'. ${ }^{3}$ Sawles Warde uses the personification of virtues to urge guarding the soul against sin, and includes a graphic depiction of the horrors and torments of hell that would find a visual echo in the 'Doom' paintings in many churches at the time, while the saints' lives, with their emphasis on the endurance of torture and eventual martyrdom, were always popular as models of Christian fortitude. The other group of texts associated with Ancrene Wisse is known as the 'Wooing Group' and includes devotional meditations. By using English, these works made material previously available only in Latin 
accessible to a wider readership: they 'seem to have been written mainly to make material already available in Latin accessible to an audience whose first - and, in some cases, only - language was English'. ${ }^{4}$ The production of Ancrene Wisse at this time, in English, was both necessary and appropriate.

When Ancrene Wisse is read within the wider context of devotional and religious literature written in the vernacular for a lay audience, the importance of the influence of pastoral literature on its composition becomes clear. Pastoral literature is a 'somewhat amorphous' genre, but includes the material considered necessary for the pastoral care of people in western Christendom, including 'discussions of the seven deadly sins, the techniques of hearing confessions, the art of preaching, and the disciplinary teachings of canon law and of Church councils'. ${ }^{5}$ Ancrene Wisse includes warnings about the seven sins and advice on saying one's confession, and its rhetoric owes much to the contemporary art of preaching: it is as much a work of pastoral literature as it is an anchoritic work.

Joseph Goering notes that it was Leonard Boyle who coined the term pastoralia 'to encompass the many and diverse works produced in the thirteenth and subsequent centuries to educate clerics (and, gradually, the laity) in those things pertaining to the care of souls' ${ }^{6}$ Elsewhere, Goering writes of pastoralia: 'What these texts all have in common is a desire to convey in writing . . . the basic knowledge and skills necessary for exercising the pastoral care of souls in the parishes of Latin Christendom.'7 Definitions such as Goering's concentrate not on the formal qualities of pastoralia, but on its content and audience; Richard Newhauser also points out that medieval genre has more to do with content than form. ${ }^{8}$ It is generally understood that pastoralia was composed in Latin; I use the term pastoral literature for such literature in the vernacular or as an umbrella term for the Latin and vernacular material.

To understand the development of pastoralia we need to go back into the twelfth century, and the growth of the schools and new universities which were training clerics; the schools of Paris, in particular, were rapidly developing in the second half of the twelfth century. ${ }^{9}$ The development of the theology 
faculty, and the emphasis placed on preaching and other pastoral duties, can be seen as a response to the critical relationship between the institutional Church and the people to whom its priests and preachers were ministering. More secular priests were being trained in Paris, and it was to Paris that members of the newly formed mendicant orders came in the thirteenth century to study theology and develop their preaching skills. It is possible that the author of Ancrene Wisse, who may have been a Dominican, was trained in Paris.

The Fourth Lateran Council was convened towards the end of the papacy of Innocent III, and it is likely that Innocent's concern with pastoral matters and practical ethics can be traced to the time he spent in Paris shortly before $1200 .^{10}$ Innocent III - then Lothar of Segni - was educated in Paris at the time of Peter the Chanter, who was at the centre of the important circle of theologians and preachers in the second half of the twelfth century. Also educated in Paris was the English preacher Odo of Cheriton, whose style has been compared to that of the author of Ancrene Wisse. ${ }^{11}$ The Fourth Lateran Council insisted that all parishioners should confess privately to their own parish priests, who had to be 'discerners of souls and not simply dispensers of absolution and penance'. ${ }^{12}$ The movement towards an insistence on contrition and personal confession, and the replacement of public acts of penance by private penitence, however, predated 1215. The penitentials of the early Middle Ages, especially in Ireland, emphasized contrition and provided an alternative to public penance. Such penitentials became part of the work of the parish clergy, and 'as pastoral textbooks they continued to evolve until we arrive at the Summae confessorum in the twelfth century'. ${ }^{13}$ The emphasis on personal confession and private penitence assumes an emphasis on the inner life, rather than outward acts; Giles Constable sees the concern with confession as linked with the interiorization of religion and the consequent emphasis on intentions rather than actions: 'This concentration on the inner life of monks paralleled the tendency in moral theology to emphasize the importance of intention in the doctrine of sin and of repentance in the doctrine of confession and penance.' 14 This is the natural conclusion of Abelard's 
insistence on the importance of intention in understanding and ascribing sin, discussed above. The new emphasis on personal confession and private penance led away from a formulaic system of penances and towards an emphasis on intention and contrition.

Rita Copeland acknowledges two genres of confessional treatises: 'instructions to priests on conducting confession and prescribing penances, and instructions to lay people on preparing for and making confession'. ${ }^{15}$ Parish priests needed to be educated if they were to carry out the role of confessor effectively; it was to help in this effort that works on confession, including the Summa confessorum of Thomas of Chobham, were produced in the thirteenth century. Thomas of Chobham was a member of Peter the Chanter's circle, though of a later generation; much of Chobham's inaugural sermon when he was licensed to teach theology in Paris was influenced by the teaching of the Chanter, including his assertion that 'the Albigensian heretics would not have succeeded if there had been an active faculty of theology in the Languedoc' ${ }^{16}$ Thomas was English, but had studied in Paris as a young man before returning to England to serve under Herbert Poore, Bishop of Salisbury; he was sub-deacon of Salisbury from 1208 and then taught as a master of theology in Paris from 1222 to 1228 before returning again to Salisbury. ${ }^{17} \mathrm{He}$ died in 1236 and left a collection of sermons, as well as summae on preaching, confession, and the vices and virtues.

The work of Thomas of Chobham may provide a useful reference for the kind of pastoral material influential in the first half of the thirteenth century - the time of the composition of Ancrene Wisse - and with an English source. Chobham's Summa confessorum was designed to aid priests in the fulfilment of their duties, though it is not apparent whether its intended primary readership was parish clergy or those responsible for their training and education. The duties of the parish priest - and their limitations - are set out in clearly defined chapters and parts. Chobham details the things necessary for a priest to know, including how he should instruct the penitent and hear his confession; he makes it clear that the point of the periods of penitence enjoined on the penitent by his priest were so that the penitent could keep in 
mind his sin, as a source of regret and sorrow. ${ }^{18}$ Satisfaction, as well as contrition and confession, was essential for the sacrament of penance; this consisted of three 'species': fasting, praying and alms-giving. ${ }^{19}$ Some suffering was required for true satisfaction.

The language in which confession is described is both legal and medicinal: a penalty must be paid for sin, but this can act as a medicine for the curing of the soul of the penitent. To an extent, the Summa confessorum acts as a sourcebook, giving a summary of knowledge and authorities on $\sin$ and virtue; Chobham quotes Gregory on the seven mortal sins, and discusses Augustine and the Apostle Paul on the sins. ${ }^{20}$ Chobham's overall concern is with morality; more detail on the nature of the sins and the remedies for them is provided in his Summa de commendatione virtutum et extirpatione vitiorum. Moral teaching is inextricably linked with the art of preaching: Chobham's sermons are concerned with the commending of virtue and condemning of vices, while his summa on the vices and virtues stresses the importance of preaching.

The first chapter of Chobham's summa on the vices and virtues is on the word of God, which provides the soul with spiritual healing and nourishment: 'For the divine word cures all the wounds of sin.' ${ }^{21}$ Although imagistic themes, such as the healing power of penitence, underpin Chobham's argument in his summae, he rarely uses exempla. The role of exempla in sermons will be discussed in the next section; but it is interesting to note here that the only exempla in Chobham's Summa confessorum occur in sections of particular relevance to the laity. Capitulum $\mathrm{x}$ of Questio IIIa, on the Eucharist, is concerned with the things that are required of the laity and includes the following story from Gregory's Dialogorum libri, which was also used by James of Vitry:

The blessed Gregory tells the story of how, when a certain woman was possessed by a demon and a priest had entreated the demon to leave, the demon replied: you do me an injustice, since I did not enter this woman by myself but rather she introduced me into herself. For I was sitting in the garden on a lettuce, and the woman, having entered, saw the lettuce and took it without a blessing and consumed me at the same time as the lettuce. ${ }^{22}$ 
This exemplum serves as a warning and an illustration of the injunction that, whenever one sits down to a meal, one should bless the food and give thanks to God. The issue of confession also had relevance to the laity, and an exemplum is given of a woman who was reluctant to confess a crime to her priest and so wrote it down and left it next to the altar, in order to explain the necessity of confession being oral. ${ }^{23}$

An important aspect of the rhetoric of pastoralia was its structure or organization. Division was a rhetorical device determining the structure of the work - but it also promoted accessibility. Works that were divided into clear parts with headings could be used more easily for reference. The Prologue to the twelfth-century Premonstratensian statutes insists on the accessibility of that work:

Because of these things, so that we may provide for both the peace and the unity of the whole Order, we have carefully composed this book, which we call the book of customs, in which we characterise four distinctiones in their places, as much for the variety of the contents as for the convenience of the readers. ${ }^{24}$

It was with such distinctiones in mind that the author of Ancrene Wisse announced in the Preface that his work was to be divided into 'eight destinctiuns which you call parts'. ${ }^{25}$ Richard and Mary Rouse point out that:

Such divisions and subdivisions had to constitute coherent units, so that the process of division would aid the reader to understand the organization of the whole work and the intent of its author; and the units had to be small enough to serve for reference purposes. ${ }^{26}$

The use of division and subdivision to organize material and structure texts was an important feature of the rhetoric of medieval pastoral literature. The point of rhetoric is to communicate ideas and information as effectively as possible, and how material is organized contributes to its effectiveness. Fundamental to the organization of written material in the high Middle Ages, the scholastic age, was the principle of division. D'Avray criticizes the characterization of new 
sermons of the thirteenth century as 'scholastic', and outlines the debate on this, ${ }^{27}$ pointing out that sermons do not include some of the essential features of scholasticism, particularly the use of questiones, but he does concede that mendicant preaching and scholastic theology share a 'subdividing mentality' and, indeed, that academic summae and treatises, produced by scholastics, and sermons, produced by preachers, are both species of this 'genus'. ${ }^{28}$

Division as a method of construction and of organizing material is also seen in other forms of pastoralia, such as treatises on confession, where it can aid memory and help the recall of important features. Division of a work into accessible parts changed the way it could be used; as Paul Saenger has pointed out, subdivisions (such as distinctiones), indexes and headings made it easier to isolate 'units of intellectual content', and so it became possible to refer to an item in a longer work rather than read through the whole continuous work: this division of works into chapters was an important development in the composition of texts. ${ }^{29}$ Nor was the use of division and subdivision confined to academic texts, as is seen in this description of a chapter of the Legenda Aurea or 'Golden Legend' of James of Varazze:

The chapter on All Saints is a typical example of Jacobus's way of developing his arguments. One feature of his method meets the reader from the first sentence on: there were four 'causes' (reasons, purposes) for the institution of the feast; each of the four will be studied under three, four, five subdivisions, and each subdivision under a number of sub-subdivisions. ${ }^{30}$

The Legenda Aurea was a popular thirteenth-century work that could be considered a collection of exempla; it is a 'treasure-house' of stories about the saints. ${ }^{31}$ The author was himself a member of the Order of Preachers and also left several volumes of sermons. The Legenda Aurea could be mined by preachers for their sermons, but in its vernacular translations it also spoke directly to lay people.

There is a question about how much of the pastoralia of the thirteenth century was intended for the use of parish priests since, although the parish priest should have been able to read the Latin of the liturgy, he may well not have been able to 
cope with the Latin pastoral texts produced in universities and schools. Goering argues that it was not necessary for parish priests to be educated, and suggests that, at a time when many more people were obtaining a scholastic education, it was 'students in the schools' who became the earliest audience for the practical literature of pastoral care. ${ }^{32}$ Bloomfield, however, argues that the Summa confessorum of Thomas of Chobham was directed not at theology students but at priests in the administration of their office, ${ }^{33}$ and Goering does conclude that 'By the end of the thirteenth century such collections [of distinctiones and model sermons] were in common use among preachers and pastors'. ${ }^{34}$ It is likely that the pastoral literature emanating from Paris, such as summae and collections of model sermons, had a gradual effect upon parish clergy. Over a period of time, the ideas contained in these books were translated into simpler guidebooks and collections of sermons for the use of parish clergy. ${ }^{35}$ 


\section{7 \\ The rhetoric of preaching}

It cannot be assumed that the theory of preaching taught in the theology schools of Paris led directly to changes in pastoral practice in the parishes. Despite the emphasis the Fourth Lateran Council placed on confession and preaching as the prime responsibilities of priests with a duty of pastoral care - bishops in the first instance - we cannot be sure of the ability of parish clergy in this period to teach and preach to their congregations. Parish clergy in the early Middle Ages tended to be poorly educated themselves and unable to teach their parishioners adequately about the Christian faith; it may well be 'inconceivable' that parish clergy were preaching in country churches in the twelfth century. ${ }^{1}$ It was a requirement, reiterated in the epsicopal constitutions of the thirteenth century, that parish priests should teach their parishioners the Pater Noster and Apostles' Creed, but we cannot know how much the laity understood of the doctrines of their faith. ${ }^{2}$ Parish priests, who were not themselves university-educated, would have known little more than their parishioners. Even in the late fourteenth century, Langland could present Sloth as a parish priest who could neither sing the services nor read saints' lives. ${ }^{3}$

The Archbishop of Canterbury, Stephen Langton, in the Statutes of Canterbury of 1213-14, required that all adult Christians should at least know the Lord's Prayer and Apostles' Creed, assuming it was the duty of the parish priest to make sure they did so and, where possible, to help them to learn more. ${ }^{4}$ The Third Lateran Council of 1179 had decreed that free teaching should be provided: 'In every cathedral church a master is to be assigned some proper benefice so that he may teach the clerics of that church and the poor scholars. ${ }^{5}$ The Fourth Lateran Council, however, acknowledged that this 
decree been little observed; it made provision, therefore, for the teaching of 'grammar and other branches of study' to the clerics of the Church, and also required that at least the metropolitan church should have 'a theologian to teach scripture to priests and others and especially to instruct them in matters which are recognized as pertaining to the cure of souls'. ${ }^{6}$ It is not entirely clear whether the authorities of the Church were imposing higher standards on their priests, or responding to demands from 'poor scholars' for education. It seems, however, that the English bishops had implemented Canon 18 of the Third Lateran Council 'without the need for further prompting' ${ }^{7}$

Alexander of Ashby, who was the prior of the Augustinian house of Ashby near Northampton in the late twelfth century, commented on how many more opportunities for being taught - 'drinking at the fountain of wisdom and theology' there were as he wrote than there had been when he was a boy. ${ }^{8}$ Alexander made this comment in his work on preaching, in which he insisted on the importance of clerics being sufficiently educated to perform their pastoral duties: there should be enough appropriate schools so that they could not remain in ignorance. ${ }^{9}$ Alexander's guide to preaching was one of the earliest of the preaching aids, following that of Alan of Lille; others of the early preaching aids, including those by William de Montibus and Thomas of Chobham, also originated in England. It is worth remembering that the area in which Ancrene Wisse was written was one served by reforming bishops at this period.

Preaching guides, or artes praedicandi, such as that of Alexander Ashby, flourished at the turn of the thirteenth century, supplying advice on the construction, and function of and rhetorical devices for sermons. The production of such guides was further stimulated by the requirements of the Fourth Lateran Council, the tenth decree of which, 'De praedicatoribus instituendis', 'On appointing preachers', insisted on the importance of preaching to the people, since man lives, not by bread alone, but 'by every word that proceeds out of the mouth of God' ${ }^{10}$ A new form of sermon was developing at this time; it is known as the modern, or university, sermon and its construction was based on the 
principle of division, as described by John of Wales, 'an Oxford friar who produced material for preachers': ${ }^{11}$ 'Preaching means the adoption of a theme, the division of that theme once it has been divided, the appropriate consultation of concordances, and the plain and pious exposition of the auctoritates which have been adduced.' ${ }^{12}$ As John of Wales explained, this new kind of sermon was composed on a theme, usually a line from the Bible, which was expanded and explained in a discourse that was carefully constructed by means of division and subdivision. This was a structure which was associated with the new universities, and so with scholasticism. ${ }^{13}$ Nicole Bériou claims it is this structure which defines the new sermons, as they moved away from the more fluid form of older homilies, and she mentions the division of the theme as the main structural device of these sermons. ${ }^{14}$ This model of the thematic sermon was used in preaching to the beguines of Paris.

Chobham's Summa de arte praedicandi-summa on the art of preaching - is concerned with the rhetoric of preaching. Chobham was conscious of classical rhetoric: he referred to the De inventione and Ad herennium of Cicero, and wrote on the parts of the art of rhetoric: inventio, depositio, elocutio, memoria, pronunciatio. ${ }^{15}$ However, Chobham also emphasized the exegesis of the Scriptures and the moral role of the preachers; preaching differs from studying in that it involves, not just the exegesis of the divine word, but its declaration. ${ }^{16}$ Chobham, following Peter the Chanter, declared that the study of Scripture consisted of reading, disputation and preaching, reading and disputation being subservient to preaching. When dealing with individual sins, Chobham criticized preachers who do not preach against sloth, but are themselves slothful; he insisted that preachers and confessors should understand the nature of this sin, and protect men against it. ${ }^{17}$ Chobham's summa is clearly directed toward preachers, covering what they need to know in the exercise of their duties: he had been influenced by Peter the Chanter's attempt to apply the developing academic study of theology to issues of practical morality. ${ }^{18}$

As Chobham's own works of pastoralia, the Summa de arte praedicandi, Summa de commendatione virtutum et 
extirpatione vitiorum and Summa confessorum, are organized by careful division and subdivision, allowing readers to find and refer to material easily, so he also insisted on divisio as an element in the art of preaching. In the Summa de arte praedicandi, Chobham lists divisio as the third of the 'parts of oratory in rhetoric'. He also lists 'parts of the art of rhetoric', which are the classical rhetorical devices of inventio, dispositio, elocutio, memoria and pronunciatio. These devices can be applied to each of the 'parts of oratory'; so, in what is itself a paradigm of medieval subdivision, section 2.1.3. of Capitulum 7, De arte praedicandi, is headed 'De inventione in divisionibus'. ${ }^{19}$ It is here that Chobham discussed the construction of a sermon, and the development of its theme, by division. This use of division is promoted in many of the artes praedicandi: in both Alan of Lille's De arte praedicatoria and Alexander of Ashby's De modo praedicandi, the sermon is understood as an explanation of a theme from scripture by means of divisio. ${ }^{20}$

Divisio can apply to the dividing of the whole sermon into many parts, or it can apply to the division of a word, 'unicum verbum', ${ }^{21}$ into different levels of symbolic or figurative meaning - another term for this kind of 'division' is distinctio. Distinctiones distinguish between things - levels of meaning or structural levels within a longer work. Collections of distinctiones to be used in sermons and moral teaching flourished in the late twelfth century, with examples by Alan of Lille, Stephen Langton and William de Montibus, who died in 1213. William's collection, the Distinctiones theologice, is a textbook example of the genre; it includes 'examples of the various meanings of a word in scripture - its literal as well as its 'spiritual' (moral, anagogical, and tropological) senses'. ${ }^{22}$ The first example given in William's collection is arcus, which Goering edits in full; arcus means rainbow and is said [to signify] Christ and propitiating of God, scripture, judgement, strength, intention [or the exertion of mind], trickery and deceit'. ${ }^{23}$ Arcus also means bow, the weapon, and it is in this sense that it signifies judgement:

The bow is also said to be judgement, as in 'For they fled in the face of the bow' and in Lamentations, 'He has bent his bow like 
an enemy', etc. In the solid wood of the bow is understood the power and resolution of God now withholding judgement; but in the day of judgement, the string, stretched and displayed, will be added and fitted. This is justice hurling sharp arrows, that is words that are harsh, more harsh and most harsh of all. ${ }^{24}$

Mary and Richard Rouse comment on a 'late twelfth-century distinctio on the word nubes' that it hardly counts as an explanation of the meaning of the word nubes (cloud) - but it does say a lot about how the word nubes could be used and interpreted. ${ }^{25}$ Where a word such as nubes or arcus appeared in the theme of a sermon, the layered significations of the word could be used to provide meaning and to structure the sermon.

The study of the Bible was central to preaching throughout the Middle Ages. In the early thirteenth century, modern sermons were innovatory in their form, and were to have a great influence on preaching throughout the Church, but the older homiletic tradition must not be forgotten. Sermons belonging to the monastic, as opposed to scholastic, tradition tended to be organized in a different manner. While both were concerned with exegesis of the Scriptures, they served a different purpose: in the monastery, as opposed to the schoolroom, the concern is not with academic pursuits, but with the achievement of salvation. Immersion in the Scriptures allowed monastic discourse, including sermons preached in monasteries, to be rich in allusion and allegory. Jean Leclercq sees a difference in construction in monastic sermons - a construction not based on division, but provided by reminiscence. Certain words set up 'a kind of chain reaction': 'Each word is like a hook, so to speak; it catches hold of one or several others which become linked together and make up the fabric of the exposé. ${ }^{26}$ Such a method is seen in the work of Bernard of Clairvaux, whose immersion in the Scriptures was exceptional even by the standards of his time; his near contemporary, John of Salisbury, described him as:

so saturated in the Holy Scriptures that he could fully expound every subject in the words of the prophets and apostles. For he had made their speech his own, and could hardly converse or preach or write a letter except in the language of Scripture. ${ }^{27}$ 
In the fourteenth century, Robert of Basevorn wrote in his Forma Praedicandi:

Now, about St Bernard. It must be realized that his method is 'without method', exceeding the style and capability of almost all men of genius. He more than all the rest stresses Scripture in all his sayings so that there is hardly one of his sentences that does not depend on the authority of the Bible or many [other] authorities. $^{28}$

This complete immersion in the language and imagery of the Bible allowed chains of images or similitudines, to be constructed; D'Avray writes of 'a passion for similitudines of all kinds, so pronounced as to bring thirteenth-century preaching nearer to the conventions of modern poetry than of modern prose'. ${ }^{29}$ Similitudines cannot be equated directly with similes; they are often elaborated at great length and can be similar to exempla - short narratives with a moral - on the one hand, or to extended distinctiones - developing the image of a scriptural passage - on the other. ${ }^{30}$ In the same way that distinctiones could be used to structure an argument, so similitudines could be used to organize and arrange material in a sermon. Scholastic sermons, such as those by Thomas Aquinas, would be structured through distinctiones, but other sermons, in particular those aimed at a wider audience, would often use lengthy similitudines to form the basic structure. Louis-Jacques Bataillon uses a sermon by Guillaume de Mailly as an example of a sermon in which two main similitudines, which themselves contain chains of comparisons, are essential to the composition of the sermon. ${ }^{31}$ As lengthy patterns of imagery, similitudines would seem to be particularly appropriate for an uneducated, lay audience, but the method of sermon-constructing associated with the universities - the methodical division of a theme - is also adapted and used for lay preaching, and one should not be too dogmatic about separating monastic and scholastic, or lay and clerical, styles. The same author could employ different styles depending upon his audience: different styles are found in the sermons of James of Vitry.

James of Vitry was another Paris-educated theologian influenced by Peter the Chanter. Preaching was central to 
James of Vitry's life and vocation: he saw pastoral care as 'the overriding raison d'être of the clergy'. ${ }^{32}$ As well as being an advocate of the Dominicans and Franciscans and a supporter of the quasi-regular beguines, ${ }^{33}$ James wanted to make the teaching of the Church accessible to lay people; in the Prologue to his sermons for Sundays throughout the year, he warned that the cautious preacher should pay attention to how much he tries to include in a sermon to lay people: 'For it is better that they are sent away from here hungry to hear more than that they should be weighed down with too many words. 34 Moral teaching is, again, a spiritual food for the people.

In these Sunday sermons, there is a scholastic pattern of division; for example, the sermon for the beginning of Lent is organized around a methodological list of the reasons for the observance of Lent. ${ }^{35}$ The second sermon for the beginning of Lent takes a theme from Joel: 'Turn ye even to me with all your heart, and with fasting, and with weeping, and with mourning: And rend your heart, and not your garments. ${ }^{36}$ This theme is divided to provide an account of what penance should be: the sinner should turn to the Lord with his whole heart, that he might fully repent. A perfect repentance consists of three things: the weeping and lamenting of contrition; the opening of the heart through the power of confession; and the effort of satisfaction. It is the heart, not merely the outer garments, that must be torn.

The sermon for the first Sunday of Lent deals with the nature of temptations, and includes a scriptural image found also in Ancrene Wisse: an arrow flying in the day signifies a slight and open temptation, but the thing that walks in the shadows is a serious and hidden temptation. ${ }^{37}$ This interpretation of verses from Psalm 91 was common in late twelfth-century writers and is found also in the Distinctiones of Alan of Lille. ${ }^{38}$ This does not prove that the author of Ancrene Wisse had read the works of James of Vitry and Alan of Lille, but rather suggests that those writing on similar themes and with the same purpose were using a common pool of imagery and rhetorical devices.

James of Vitry employs different methods in his Sermones ad status, that is, the sermons composed for particular kinds of audience. ${ }^{39}$ In his sermon to be preached to vineyard- 
workers and other labourers, the style is more discursive. A theme is taken, and the images it presents provoke the recall of similar images from the Scriptures and Fathers; for example, the image of sowing seed and working the fields is appropriated and developed metaphorically, with scriptural and patristic quotations and exempla. The importance of working despite adverse circumstances is stressed and linked to Adam's penance: ${ }^{40}$ it is the penitential intention in the work that matters, not the work itself, or brute animals would deserve the same reward. Further agricultural metaphors are used to condemn avarice, warn against heresy and remind listeners to fulfil their obligations of tithes and charity to the poor; these images have both structural and illustrative roles. James of Vitry was at the forefront of the mission to educate preachers, and his collections of sermons and exempla were a valuable resource for preachers. Humbert of Romans, who was Master of the Order of Preachers from 1254, wrote of James of Vitry that he 'set the whole of France on fire with his sermons in that kingdom, by using exempla'. ${ }^{41}$

Thomas of Chobham's sermons also relied on the use of imagery; they expand on the idea of the word of God as food for the soul, which the devil tries to take away from it:

The devil, however, loves nothing as much as the death of the soul, and hates nothing as much as the life of the soul ... There can be no better way to mortally wound the soul than to withdraw from it its life, that is, the word of God. ${ }^{42}$

The image of the hunger of the soul is more than a rhetorical device - the soul is conceived as a spiritual reality on the model of the body, with the same kinds of needs, and facing the very real danger of attacks from the devil. The demons Jesus cast out caused bodily sickness, but they signified $\sin .^{43}$ The use of the image of spiritual sickness is not peculiar to preachers of this period, ${ }^{44}$ but this conception of the concrete reality of the spiritual world and its intimate interaction with the material world - confirmed by the incarnation of God in the person of Jesus - informs the language used by all preachers of this period, and by the author of Ancrene Wisse, who also uses the image of Jesus as a spiritual healer. 
In his inceptio, his inaugural sermon, Thomas of Chobham expressed concerns about the role of the theologian in the wider world: he should be like a shepherd guarding his flocks by night and providing them with fresh hay. The schools are the pastures where fresh grass is gathered to be dried and scattered as food for the sheep and cows. ${ }^{45}$ These are images familiar from the daily experience of people, but underlying the images is the figure of Jesus as the shepherd - pastor in Latin - and the implicit identification of the preacher with Christ. Here we see both ideas about the role of the preacher - that he should be a Christ-like shepherd protecting and guiding his flock - and something of the way in which the message should be conveyed to the flock, in metaphoric language speaking of the daily experiences of people, and supported by biblical references and allusions.

Metaphors and biblical references were one method of illustrating or amplifying the theme of a sermon; such amplification was known as dilatatio. Michèle Mulchahey lists the methods, or tools, the thirteenth-century preacher had to hand for this process: the chaining of authorities; biblical exegesis; definition or etymology; metaphorical explanation; argumentation and exemplum, ${ }^{46}$ many of which can also be discerned in the rhetoric of Ancrene Wisse. In particular, the author of Ancrene Wisse makes innovative use of vernacular exempla. Exempla were particularly suitable for preaching to lay people: the term is used either for stories of ordinary life with a moral, or for saints' lives which were a model, or example, for conduct in life. It is in this second sense that Basevorn gives the use of exempla as a form of reasoning: 'The third way of reasoning is by example; this avails much with lay people who are pleased with examples.' ${ }^{27}$ The exempla used by James of Vitry tended to be about contemporary life; in the sermon to farm-workers we have already commented upon, he included a story about an old peasant who had learnt what days were festivals and holy days, and on such days always wore red shoes, so that, when they saw him wearing his red shoes, other servants would say, 'Today we should take a holiday because master Gocelinus is wearing red shoes. ${ }^{48}$ In his life of Mary of Oignies, James of Vitry described the lives of holy women as models of 
behaviour, 'since many are moved by examples who are not moved by commands'. Exempla or stories of the saints were a palatable form of spiritual food for the poor and for children who feed on crumbs falling from the master's table: ${ }^{49}$ another example of the image of spiritual guidance as food, which is so pervasive in pastoral literature.

Jacques le Goff associates exempla 'with a new kind of preaching that came into vogue at the end of the twelfth and beginning of the thirteenth century to suit the needs of a changed society'. ${ }^{50}$ At this time collections of exempla were becoming common; they were the 'spices of the spiritual exegesis', and their use by Paris masters such as Peter the Chanter was connected with the revival of popular preaching. ${ }^{51}$ There is also the suggestion of an oral performance - as would be expected of a sermon - though exempla can be found in other forms of pastoralia. The simplest definition of an exemplum is that it is a short story with a moral purpose - to be effective, it must be convincing. ${ }^{52}$ Preachers no longer relied on stories from the Scriptures or lives of the saints; as they needed to appeal to a new audience they began to use short moral stories of contemporary life, and exempla were often produced by Dominican compilers. ${ }^{53}$ Preachers were expected to add exempla, similitudes, analogies and other illustrations suitable for their particular audiences, although these are often missing from model sermons and reportationes - recordings of sermons, either official or in the notebooks of students. ${ }^{54}$

Another method of illustration is the enthymeme; this device puts forward an argument on the lines of 'he would, wouldn't he?' It lacks the logical certainty of a syllogism, but for Basevorn it was a form of reasoning that was a valid method of amplification in sermons. By asking the audience to draw the conclusion, the preacher was involving them in the process and appealing, if not to their powers of logic, then certainly to their common sense:

For example: Would he not be foolish who would weave or make a rope with which his enemy would hang him? Such a one is he who commits a sin by which he is damned. Prov. 5:22: Each one is fast bound with the ropes of his own sins. ${ }^{55}$ 
The use of a scriptural quotation clinches the argument: if the grounds or premise of the argument is taken from the Scriptures, then the truth value of the argument as a whole is of a different, superior, kind. The medieval preacher would not have seen the use of the enthymeme as any less valid an argument than logical deduction; it was part of his arsenal of weapons for the persuasion of his audience.

The use of distinctiones, similitudines, exempla and enthymemes was not merely ornamental; the mode of thinking that made use of such language in sermons was more than an effective means of communication, or a device for organizing material: it was fundamental to how medieval authors conceived the world. It was an allegorical mode of thinking: allegory was pervasive in all areas of medieval life. In the Middle Ages, allegory was understood as a form of biblical exegesis, and could be defined as 'seeking correspondences between different realms of meaning (e.g. physical and spiritual) or between the Old Testament and the New'. ${ }^{56}$ Beryl Smalley claims that, in the twelfth-century revival of popular preaching, 'allegory could be used for instructing the laity, for presenting to them the Church and her sacraments in a concrete and intelligible form'. ${ }^{57}$ It was the basis of much theological thinking and writing, but also underpinned the popular understanding of faith. That 'Medieval man thought in terms of symbols' may be an axiomatic commonplace 'usually found on page one of any book' on the medieval mind, ${ }^{58}$ but it was the resemblance between the spiritual and physical realms that gave significance and meaning to the world. This was a world-view that believed the material world corresponded to the spiritual, that the known world in some way represented, and so could reveal the unknown God: the allegory of the Scriptures revealed God, but the world itself was sacramental - an expression of the purpose of God. ${ }^{59}$ 


\section{8 \\ Beguine sermons}

Sermons were a central part of the pastoral reform of the high Middle Ages, and are recognized now as an important form of vernacular religious literature, accessible to a wide population. Sermons formed part of the education of beguines who, like the anchoresses for whom Ancrene Wisse was written, were quasi-regular women living a religious life but not within a convent. ${ }^{1}$ Our appreciation of Ancrene Wisse within the context of pastoral literature can be enhanced by a comparison with some of the sermons written as guidance and instruction for beguines. In Paris, in the liturgical year $1272-3$, a series of sermons preached in various chapels and churches was recorded; they included sermons preached at the Beguinage of Paris, which have been edited by Nicole Bériou. ${ }^{2}$ This collection of sermons is unusual in that they were recorded in detail; sermon collections, of either model sermons or reportationes, usually gave a more schematic form of the sermon. It is the elaborations that are often missing from sermon collections - the stories and similes - and which are present in Ancrene Wisse that make it such a rich and interesting text; a comparison with the beguine sermons, which include these elaborations, is therefore of great interest.

They were recorded in Latin, although they were probably delivered in French; occasionally French words are inserted Hubert of Sorbonne glosses the Latin tribulationes as les triboiz. ${ }^{3}$ It is also possible that these sermons were intended for other audiences as well as the beguines; in the same sermon, Hubert addresses his audience in the masculine as 'dilectissimi'. ${ }^{4}$ Hubert also uses an image of the schoolmaster beating his pupils, and draws a comparison between the master and God: 'And so we are quite rightly like the boy who, whenever he was beaten for his own good, nevertheless 
wept. So we always weep and are dissatisfied with ourselves when God himself beats us. ${ }^{5}$ Other imagery in the sermons is not specifically relevant to the beguines; in a sermon by Nicholas de Gorran, the steering of a ship towards its final destination is given as an example of always keeping the end of actions in view: if the end is good, so is the action which leads to it. The sermon continues with the example of going for a drink:

Look to the likely result! You will probably spend in an hour what it has taken a week to earn and, worse, since you drink too much you get a hangover or abuse someone who will kill you on the spot while you are in mortal sin. ${ }^{6}$

One suspects that these sermons may not only have been preached in the Beguinage, but have had other audiences in Paris.

The preachers of the sermons delivered at the Beguinage included almost equal numbers preached by Dominicans, Franciscans and secular preachers; ${ }^{7}$ mendicant friars clearly played an important role in the education and spiritual instruction of these beguines, as they did for the beguines in the Low Countries. Sermons were an important form of educating and controlling beguines. Four of James of Vitry's Sermones ad vulgares were addressed to beguines, and his Sermones de sanctis on virgins and on other holy women would also have been appropriate for an audience of beguines; in the 'Second Sermon to Virgins and Young Girls' from the Sermones ad status he explicitly mentions beguines. ${ }^{8}$ Penny Galloway has also found evidence of beguines in Flanders listening to sermons, as mentioned in descriptions of patronal festivities at Champfleury and in the statutes of the Beguinage of St Elisabeth in Ghent, which 'decreed that the women of this community were obliged to be present at all sermons in their church'. 9 Brenda Bolton has pointed out that beguines, 'like most urban audiences', were eager to receive instruction, 'which usually came in the form of preaching', and she draws an explicit comparison with Ancrene Wisse and other works in the Katherine Group. Ancrene Wisse is not a sermon, in that, although probably intended to be read out 
loud, it is not essentially performative, nor does it allow for improvization; nevertheless, I believe valid comparisons can be made which will throw light on both the rhetoric of the text of Ancrene Wisse and the spiritual context in which it was composed.

The author of Ancrene Wisse was making conscious use of the sermon rhetoric that was emanating from Paris at the beginning of the thirteenth century. The burgeoning of sermons and other pastoral literature aimed at a lay audience is evidence of the democratization of a previously clerical or monastic spirituality, now being made available to an increasingly literate lay public. Ancrene Wisse was a new kind of vernacular, devotional literature, and sermons written for beguines occupy the same space. The literature commonly associated with the beguines, the hagiographies of them and their writings on bridal mysticism and the ecstatic apprehension of the Host, for example, tend to highlight their emotionalism and extreme behaviour. However, such extreme behaviour was not common, and the sermons are concerned more with control and moderation. The preachers to the Paris beguines, like the author of Ancrene Wisse, advocated moderation, rather than the extreme emotionalism expressed in the writings of the early Flemish beguines. The preachers, aware of attacks made on beguines, were anxious that they should conform. ${ }^{10}$ Bériou refers to the 'prudence' of the preachers, 'who, besides, insist on the preparation of the soul for the mystic life, rather than on the mystic union itself' ${ }^{11}$

The Paris beguines were in a privileged position, since the Paris Beguinage had been founded by Louis IX, who was canonized after his death while on crusade, and who supported the 'feminine religious movement'. The beguines continued to enjoy royal support after the death of Louis, and the beguines also found favour with the Pope. ${ }^{12}$ Nevertheless, conformity and orthodoxy were particularly important, given the uncertain position that beguines, like the anchoresses, occupied. This uncertainty (amounting almost to paradox) were the beguines religious or lay women? - raised difficulties for the preachers, who had to address both young girls and widows, and women from a variety of social classes. ${ }^{13}$ Nevertheless, common themes emerge, in particular the 
importance of the penitential life: penitence was the vocation of the beguines, and a model of the penitential life was put before them in the sermons. The theme of penitence was enforced by images of suffering; these included images of bodily suffering and unpleasant feelings, such as the distressing vision of the suffering of Christ on the cross. As in the vision of Julian of Norwich, his skin is blackened. ${ }^{14}$ Penitence is seen as punishment, but also as a way of avoiding hell and even gaining heaven.

The theme of penitence is closely linked to that of temptation; Hubert of Sorbonne's sermon uses the theme of prosecuting the battle of life in order to win the reward of heaven to provide, not only the imagistic language of the sermon, but also its whole structure: the image is not an illustrative metaphor but the shape of the argument. A brief analysis of Hubert's sermon will give an account of how a medieval sermon achieved its effects. ${ }^{15}$ The imagery used by Hubert is not uncommon; what is interesting is that we have here a full account of a sermon organized as a 'modern sermon' according to thirteenth-century pastoral ideas and delivered to an audience that is comparable to the anchoresses. We will see later the influence of the modern sermon, and its structured form, on the rhetoric of Ancrene Wisse. The structure of Hubert's sermon is typical of a thirteenth-century sermon, with Protheme, Theme, Introduction, Division and Development. Hubert takes a theme from the second epistle of St Timothy, 'A man will not be crowned unless he strive lawfully' ( 2 Timothy 2: 5), for his sermon to the beguines for the Feast of Saint John. The theme is explained in the Latin translation of a French proverb which states that nothing will come of nothing; and the Theme is divided into two parts: 'the battle which precedes and the prize which follows'. ${ }^{16}$ Those who wish to come to the reward of paradise must first endure the battle.

There are three battles to be fought and three levels of defence for a castle, and these are all interpreted in terms of the daily battle of the soul. As fallen people, we are placed on earth to work as labourers and fight as soldiers. Battling against the devil is, like eating bread 'in the sweat of thy face' (Genesis 3:19), an essential aspect of the penitential life - and 
all life, since the sin of Adam, must be penitential. It is not, however, one battle, but three: the first battle is against temptations, the second against troubles, and the third is that which follows from the victory over the first two, that is, ascent to contemplation. ${ }^{17}$ In the sermon, as in life, these three must be dealt with in order. There is also a tripartite order for the defence of the castle, the consecrated soul (anima sancta) or conscience being like a castle full of treasure that is greatly desired. The three lines of defence against attack are all forms of thought or meditation: the lookout is the conscience, or holy meditations, ${ }^{18}$ which see the mercenaries, or sins, approaching and vex the man, pricking his conscience so that he is able to protect himself. Secondly, good and strong men that is high-souled thoughts (fortes et magnanime cogitationes) - are required for the defence; Ancrene Wisse also suggests pious meditations and fervent prayers as a remedy against temptation. ${ }^{19}$ Women, who signify fleshly and tender musings (carnales et molles meditationes), would be of no use on the ramparts; similarly, Ancrene Wisse uses the story of a woman who was left as a doorkeeper and fell asleep: to be easily overcome is to be womanly. ${ }^{20}$ Thirdly, provisions are required for the sustaining of the fighters:

So you ought to place in your soul, which is a castle being guarded by you, provisions, that is the bread of the word of the Lord and of the examples of the holy Fathers for sustaining and nourishing holy and virile meditations and for strengthening steadfastness. ${ }^{21}$

The sermon then resumes the analysis of the three battles against temptation, against tribulation, and the ascent to contemplation.

Hubert of Sorbonne does not use the structure of the seven deadly sins that we find in Part Four of Ancrene Wisse, on Temptation, but he does mention specific sins, especially lechery, and the manner in which he discusses temptation and his emphasis on the need to be alert to the deceptions of the devil bear comparison with the voice of the author of Ancrene Wisse. The battle against the devil is not seen only in terms of medieval warfare: the devil is also like a robber, who will use 
a potion to put a merchant to sleep so that he can steal everything from him; in the same way, the devil will try to steal all the virtues and graces from the treasury of the soul. That chastity is a precious treasure is a common conceit, found also in Hali Meiðhad: virginity, 'meiðhad', is 'the treasure which, if it is once lost, will never be found again'. ${ }^{22}$ The word thesaurus is used for the treasure of virginity in Ancrene Wisse ; $^{23}$ heaven itself is compared with a 'thesaurus', a treasure that can easily be stolen:

The treasure is good works, which are compared with heaven because people buy it with them; and this treasure, unless it is better hidden and concealed, is soon lost, for as St Gregory says, Anyone who carries treasure openly on the road is asking to be robbed: anyone who carries treasure openly on a road which is crowded with bandits and thieves is asking to lose it and be robbed. ${ }^{24}$

Hubert of Sorbonne's sermon insists on the importance of guarding the treasury of the soul with its virtues and the graces; virginity is presented as the treasure above all treasures, as it is in Ancrene Wisse, where virginity is a precious ointment in a frail vessel. Virgins, being uncorrupted, are closest to God; Hubert claims that virgins can take the place in heaven left empty by the fallen angels. ${ }^{25}$ In Hali Meiðhad it is claimed that 'angel and maiden are equal in virtue through the power of virginity, though as yet their degrees of blessedness divide them'. ${ }^{26}$ Carolyn Muessig comments on the centrality of chastity in the penitential life, which was at the heart of the spirituality of beguines: 'Regardless of the marital status of the various holy women, the emphasis of their religious vision is defined through their penitential practice which places chastity at the height of their spiritual perfection. ${ }^{27}$

The second battle is that against tribulations; what is required, however, is not fighting against troubles, but the patient endurance of them; troubles are as a school for the education of the soul and a medicine for curing it, in preparation for the third and most difficult battle. The image of the doctor who recalls his patient to health through 
medicine is a familiar one as a metaphor for spiritual healing; it is used by the author of Ancrene Wisse. ${ }^{28}$ The image of the scholar who is beaten by his master, however, may be more appropriate for those who had experienced the Parisian schools. The beguines must accept the beatings of the master and the medicine of the physician once they have been brought into the care of God. They are viewed as the chosen ones, who will enjoy, not the temporary consolations of this world, but the eternal joy of the world to come.

According to Hubert of Sorbonne, victory in the first two battles, against temptation and tribulation, allows progress to the third battle, which is more heroic and more difficult (nobilius ... et difficilius). This is a remarkable battle, in which man is fighting his own nature. ${ }^{29}$ The three battles are reminiscent of Bernard's three stages of the contemplative life, ${ }^{30}$ but, as in Ancrene Wisse, it is only those who achieve the final stage who can hope to approach contemplation. There is no mention of union with God; Bériou refers to the 'prudence' of the preachers to the beguines, 'who, besides, would rather insist on the preparation of the soul for the mystic life than on the mystic union itself'. ${ }^{31}$ We do, however, find a comparison between the state of contemplation and Christ crucified upon the cross, but here used in a rather different manner. The soul, the anima, has both carnal and spiritual aspects: it touches the earth through the body but desires heaven. In contemplation it is as if suspended in midair between earth and heaven, ${ }^{32}$ neither totally on the earth nor in heaven. This suspension is linked with a verse from Job, who himself endured temptations and tribulations: 'Suspendium elegit anima mea' (Job 7: 15); suspendium, however, means the act of hanging oneself: 'My soul chooses hanging.' By hanging in mid-air, with feet raised from the earth, the anima sancta rejects all things of the earth and is identified with Christ who, on the cross, was lifted above the earth: 'It is clear that when one does not think, nor wishes to think, of anything except God and heaven, then one is hanged on the cross with Christ. This is the good soldier who has thoroughly triumphed in this battle. 33 The good soldier is contrasted with petty criminals, who, for their crimes, are buried up to their eyes in the earth - those whose affections 
and intellect and all their desires are fixed on earthly things will never be able to escape the earth and rise to heavenly things. To rise from the earth, one must cast off all earthly things, and all desire for earthly things, and be suspended on the cross of Christ.

This is the import of the whole sermon: that to rise to God one must reject all things of the earth, fighting against temptation and tribulation in order to be elevated in contemplation. At the end of the sermon, this is specifically linked to the religious life, and here we see the imagery familiar from anchoritic literature:

I will lead her in to a solitary place, and there I will speak as a close friend to her heart in counsel, and I will restore her, and I will lead her on (Hosea 2,14) by revealing to her my sweetness. And this applies especially to those who stand faithfully and have entered into the religious life, and indeed sweetly by whatever meditations on him. And so the sanctified soul says to her spouse, 'My beloved is mine and I am his' (Song of Songs $2,16) \cdot{ }^{34}$

In rejecting the things of the world, the anima sancta is no longer tied to the world, and in serving God finds a new freedom.

The life of the beguines is presented in this sermon, as the life of the anchoress is presented in Ancrene Wisse, as one of penance constructed as a constant battle against temptation. I believe, however, that the salient point is not just that we find the same kind of imagery in Ancrene Wisse and in sermons preached to beguines, but that both discourses use a careful and systematic exposition of these metaphors, applying them to the inner/outer dichotomies of the lives of these women in a way which allows them to be interpreted either on the level of an elevated and elite spirituality, or as a spirituality that could be lived out in the outer world. Both the author of Ancrene Wisse and Hubert of Sorbonne, like other Paris preachers to the beguines, use the rhetorical techniques of thirteenth-century lay preaching, using popular proverbs, concrete imagery and exempla that relate to everyday life, to popularize a spirituality that had been the province of monasticism. 
In the beguine sermons, 'the images which furnish the preachers' minds and their discourses are sometimes the same as those which appear on the walls and in the stained-glass windows of the sanctuaries'. ${ }^{35}$ Bériou points out that the sermons use simple, concrete language that is rich in imagery, ${ }^{36}$ and she comments on references to pictorial representations in a number of the sermons in this collection. In a passage attributed to the mistress of the beguines, the very stones of the church have a symbolic value. The magistra explained that one comes to a church, not for the stones or the 'chalos' (which Bériou suggests means 'la chaux' (whitewash) or, perhaps, 'les lampes') but for the holy bodies ('les sainz cors') which dwell within, as one's body is sanctified by the indwelling of the spirit. ${ }^{37}$ As the actions of the dedication and blessing of the church, in the sprinkling of holy water, have spiritual significance, so external or bodily mortification is accompanied by inner repentance and tears. The 'external' crosses in the church correspond to the internal one - that is, the memorial of the Passion which the sanctified soul ought always to hold in the heart. ${ }^{38}$ Like the author of Ancrene Wisse and, indeed, Aelred who used the white altar-cloths as the starting point of a lengthy similitudo, ${ }^{39}$ the magistra uses the physical environment of the beguines as a material correlative to their spiritual lives. 


\section{9 \\ Pastoral literature}

The sermons to the beguines may have been delivered in French, but they were recorded in Latin; gradually, pastoral literature began to appear in vernacular languages. This was literature designed initially to help priests guide parishioners, with a particular emphasis on preparing them for confession, but pastoral literature designed to be read by lay people also appeared. Ancrene Wisse is one of the first Middle English works of vernacular pastoral literature; the Vices and Virtues, found in a manuscript dated about 1200 , is a rare work to pre-date it. ${ }^{1}$ Alexandra Barratt has suggested that the use of the vernacular in Ancrene Wisse probably has more to do with the lay status of the anchoresses and their lack of opportunity to learn Latin than with any decline of learning among nuns after the Anglo-Saxon period. ${ }^{2}$ Nevertheless, the very fact that it was written in the vernacular is significant: Ancrene Wisse has for long been recognized as an important work of early Middle English; it is also important in that it is one of the earliest vernacular works that show the influence of the pastoralia that flourished in the thirteenth century. The prayers in Ancrene Wisse are in Latin, but where passages from Aelred's De Institutione Inclusarum are used in Ancrene Wisse they are translated into English, and De Institutione Inclusarum itself was translated into English for inclusion in the late fourteenth-century Vernon manuscript, where it appears alongside a later version of Ancrene Wisse. Like a parish priest using a Latin sermon to preach in the vernacular, or using a Latin confessional manual or treatise on the seven sins to help him in the directing of the confession of penitents, the author of Ancrene Wisse took the clerical Latin pastoralia and translated and adapted it for the education and direction of a vernacular audience. 
Of particular importance in the history of the pastoral literature associated with preaching were the new universities, where clerics and friars were educated. This clerical literature is not, however, the only kind of pastoral literature with which we need to concern ourselves; as well as literature designed for use by clerics, there was a growing body of literature, mostly vernacular, read by an increasingly literate lay public. Devotional literature in the vernacular intended for non-clerical audiences can be termed 'pastoral literature' and distinguished from the academic Latin pastoralia, but this distinction is neither absolute, nor always clear. In England a tradition of religious literature in the vernacular had long existed, and Old English homilies were being copied until the twelfth century, and even later. ${ }^{3}$

The rhetoric of Ancrene Wisse owes a great debt to the model of sermons of the late twelfth and thirteenth centuries, but the wide range of pastoralia, especially that on confession and penance, current at the time also had an important influence on the material contained in Ancrene Wisse. Some of the early pastoral treatises found in the vernacular were those on the vices and virtues, which proliferated in the thirteenth century: as a preparation for confession, they listed and defined the seven capital sins, the offshoots or progeny of these sins, and remedies for them. 'Capital' here has the sense of a heading: these are the habitual sins from which all other sins and sinful acts derive. Chobham, following Gregory, lists pride first as the root of all sins and the sin through which our first parents were corrupted. ${ }^{4}$ Although treatises on the vices - including lists of sins - had existed since the early years of the Christian Church, these were mainly clerical. It was after the Fourth Lateran Council, and the new emphasis on confession of all people, that such treatises burgeoned and began to address the needs of the laity, and those clerics ministering to them. Particularly influential were three penitential treatises produced by Dominicans in the thirteenth century: Pennaforte's Summa casuum poenitentiae, Peraldus's Summa seu tractatus de virtutibus et vitiis and Lorens of Orleans's Somme le Roy.

Raymond Pennaforte was a Catalonian who studied and taught at Barcelona and then Bologna; he became a 
Dominican after returning to Barcelona from Bologna in around 1223 and was elected Master General of the Order in 1238. ${ }^{5}$ He was Master General for only two years before resigning, but in this period he revised the constitutions of the Order: ${ }^{6}$ these constitutions reveal his training as a lawyer. Pennaforte did not restrict himself to improving the arrangement of the constitutions and correcting the redaction, he also added new constitutions, that is those laws that do not appear in the customary of Jordan of Saxony. ${ }^{7}$ Pennaforte's Summa casuum, composed soon after he entered the Dominican order, also has a legalistic tone to it (the first sin dealt with is simony); it is a pragmatic work, designed for use by confessors in resolving doubts and unravelling knotty questions that might arise in hearing confessions'. ${ }^{8}$ Pennaforte's summa was one of a new kind of summae which tended to place a new emphasis on intention and presented, not just a list of sins and punishments, but 'a philosophy of penance and a psychology of sin'?

Arguably the most important of these treatises is the double summa of Vices and Virtues by William Peraldus. ${ }^{10}$ Very little is known of Peraldus, who seems to have been a modest man and did not ascribe his own name to the summa, though contemporary references ensure there is little doubt to its authorship. ${ }^{11}$ There is no evidence that he was educated at Paris; we know only that by 1261 he was Prior of the Dominican convent in Lyons and that he preached in Vienne during Lent 1249 . He did, however, have some contemporary renown; the chronicler Gérard de Frachet mentioned him 'avec éloge' in the Vitae Fratrum, ${ }^{12}$ and the many copies of his summa still extant witness to its popularity. Peraldus's summa was practical and met a need that was not heeded by the speculative theologians. The summa reached all levels of society; in a sermon, Robert of Sorbon told the story of a beguine who, concerned that the priests in her region spent the time before Mass in idleness, brought back from Paris a copy of the summa, sections of which were distributed, so that it could reach even the most humble of clerics. ${ }^{13}$

The dating of these treatises makes it unlikely that any were a direct influence on the composition of Ancrene Wisse; however, parallels can be drawn between Peraldus's summa 
and the treatment of the sins in Ancrene Wisse: in particular, some of the structural features, including the systematic and orderly list of the sins, and the use of subdivisions and examples, many from the Bible. The summa opens with a short 'tractatus' on vices in general, giving an account of why vices should be shunned and why God hates sin. It is sin that harms mankind: 'Neither the devil, nor evil men, nor illness, nor death, nor any adversity can harm him if he avoids sin.' ${ }^{14}$ The rest of the treatise comprises separate chapters on each of the sins, gluttony, lechery, avarice, sloth, pride, envy and anger, and finally the sins of the tongue. For each sin, reasons are given for detesting the sin, the forms the sin takes are outlined and illustrated, and remedies against the sin are provided. ${ }^{15}$

One of the longest sections in Peraldus's summa is on luxuria, the sin of lechery. Ancrene Wisse is discreet about the nature of lechery and the occasions that give rise to it, but the examples given in Peraldus's summa of 'What furnishes occasion to lechery' are similar to the warnings in Part Two of Ancrene Wisse about the dangers of being seen, and the need to guard the eyes. Peraldus warns that the sight of women is to be greatly feared, and offers 'authorities, examples and reasons'. ${ }^{16}$ One of his examples is that of Dinah, whom the author of Ancrene Wisse blames, 'not because she saw Shechem, Hamor's son, whom she sinned with, but because she let him set eyes on her'. ${ }^{17}$ In Ancrene Wisse, this story is followed by that of Bathsheba who 'by uncovering herself in David's sight, caused him to sin with her', ${ }^{18}$ a story also used by Peraldus. Peraldus also uses the examples of Joseph, whose master's wife invited him into her bed, and Judith, whose beauty allowed her to overcome Holofernes and cut off his head. In both Ancrene Wisse and Peraldus's summa the beauty of women is a pit and a trap. ${ }^{19}$

The treatises of Pennaforte and Peraldus were in Latin, but vernacular works listing and describing the sins appear on the Continent in the mid thirteenth century; the English work with the clearest reference to the chief sins - the seven 'heaued-sunnen' ${ }^{20}$ which provide the categories for the listing of sins - is in Ancrene Wisse. ${ }^{21}$ An understanding of the vices was important as a tool in preaching and confession, but also 
as a way of analysing the psychology of sin: the seven sins can be understood as 'habitual categories', the danger coming when they are not occasional events, but habits. ${ }^{22}$ The names given to these sins, and the order in which they occur, varied, but the list in Ancrene Wisse is typical, though the order varies from that in Peraldus. In Ancrene Wisse the sins are characterized as animals: the lion of pride, the serpent of poisonous envy, the unicorn of wrath, the bear of mortal sloth, the fox of avarice, the sow of gluttony, the scorpion with its tail of stinging lechery, that is, lust. ${ }^{23}$ Ancrene Wisse is the first work in English to portray the sins as animals and, Bloomfield suggests, it does so with imagery that is 'fresh and vivid', providing 'one of the best pieces of description in our early literature'. ${ }^{24}$

Most of the English treatises on the sins appeared in the fourteenth century; they were no longer manuals for priests, but works of 'lay instruction'. ${ }^{25}$ The Somme le Roy, in particular, was to become influential through fourteenthcentury vernacular translations such as the Book of Vices and Virtues, and the Azenbite of Inwit. John Gower uses the framework of the seven sins as the basis of his major work in English, the Confessio Amantis, a work that is as much about entertainment as education. Treatises on the sins tended to become incorporated into miscellanies and more general penitential handbooks; ${ }^{26}$ John Fleming lists works with an English provenance in this tradition of penitential literature, ${ }^{27}$ including the Speculum of Edmund of Abingdon, which was composed in Latin in the early thirteenth century, but became popular as an Anglo-Norman work and was later translated into English. He does not, however, mention Ancrene Wisse although in its systematic handling of the seven capital sins, as well as its advice on confession and penitence, it occupies an important place in the vernacularization of confessional and penitential literature. Ancrene Wisse is particularly important as one of the earliest works not aimed at clerics, but directly addressing a primary lay audience.

Gradually, the moral theology of Paris did percolate down to those administering pastoral care, and in the thirteenth century, clerics returning to England from studies in Paris seem to have concentrated on the practical application of their 
learning. A number of English diocesan statutes show the influence of the Fourth Lateran Council; the requirements of the statutes of Langton, Stavensby and Poore have been mentioned above. Walter de Cantilupe, Bishop of Worcester from 1236, also promoted the education of clergy, and included in his diocesan ordinances a 'detailed summary of moral theology' to aid those who heard confessions. ${ }^{28}$ In 1281, Archbishop John Pecham called a provincial council at Lambeth; one of the most influential of the canons published was chapter 9, a didactic chapter of the sort more often found in diocesan statutes: 'It provided parish priests with the rudiments of religious instruction which they needed for themselves and for the teaching of their flock.'29

This chapter, known usually by its opening words, 'Ignorantia sacerdotum', required that a priest should instruct his parishioners four times a year in the basics of Christian faith. These basics are listed as: the fourteen articles of faith; the ten commandments; the two precepts of the Gospels (love God and love your neighbour); the seven works of mercy; the seven capital sins, with their offspring; the seven principal virtues; and the seven sacraments of grace. Lest ignorance should be an excuse for evasion of this requirement, the council also published a brief summary of these basics, the seven sins being listed as superbia, invidia, ira vel odium, accidia, avaritia, gula and luxuria. ${ }^{30}$ The diocesan statutes and, in particular, Pecham's 'Ignorantia sacerdotum' had a great influence on the production of penitential literature: such literature cannot be separated from the religious context and purpose for which it was written. Formal qualities, as seen in the particular rhetoric of this genre, are important, but it is a genre defined by content rather than form. Important vernacular treatises on penitence published in England following the Council of Lambeth included the Lay Folk's Catechism.

Confession and penance were presented to the penitent as the necessary cures for the disease of sin. The author of Ancrene Wisse insists on the importance and efficacy of suffering. The most bitter remedy of penance goes back to Jerome's exposition of Isaiah, ${ }^{31}$ and in Hubert of Sorbonne's sermon the troubles of this life are a medicine for the soul. ${ }^{32}$ 
The bitter remedy can take the form of personal confession and penitence; the image of a battle wound being healed through confession is also used in the sermon for Quadragesima Sunday in the Lambeth Homilies: 'How can the physician heal you while the iron is still sticking in your wound? Never. And nor can you be properly shriven to please God Almighty, unless you forsake all your sins.' 33 Ancrene Wisse belongs within this tradition of vernacular pastoral literature in terms of both its content - it is as much a penitential work as an anchoritic one - and its rhetoric, which owes much to the pastoralia emanating from Paris.

\section{Notes to Part II}

\section{Pastoralia}

1 For an account of Ancrene Wisse, the Katherine Group and the Wooing Group, see Millett, Annotated Bibliography, pp. 5-6.

$2 A W$ Corpus Christi fo. $66^{\mathrm{a}} 19$.

3 Introduction to Millett and Wogan-Browne (eds), Medieval English Prose for Women, p. xliii.

4 Ibid., p. xiii.

5 Joseph Goering, 'Pastoralia: the popular literature of the care of souls', in Mantello and Rigg (eds), Medieval Latin, pp. 670-6 (p. 670).

6 Joseph Goering, William de Montibus: The Schools and the Literature of Pastoral Care (Toronto: Pontifical Institute of Mediaeval Studies, 1992), p. 59.

7 Goering, 'Pastoralia', p. 670.

8 Richard Newhauser, The Treatise on Vices and Virtues in Latin and the Vernacular, Typologie des Sources du Moyen Âge Occidental, Fasc. 68 (Turnhout: Brepols, 1993), pp. 59, 60.

9 G. R. Evans, Alan of Lille: The Frontiers of Theology in the Later Twelfth Century (Cambridge: Cambridge University Press, 1983), p. 5; and see D. d'Avray, The Preaching of the Friars: Sermons diffused from Paris before 1300 (Oxford: Clarendon, 1985), pp. 132-203 passim.

10 Morris, Papal Monarchy, p. 436.

11 H. Leith Spencer, English Preaching in the Late Middle Ages (Oxford: Clarendon Press, 1993), p. 86.

12 Boyle, 'Fourth Lateran Council', p. 32. 
13 Thomas O'Loughlin, 'Penitentials and pastoral care', in G. R. Evans (ed.), A History of Pastoral Care (London: Cassell, 2000), pp. 93-111 (p. 106).

14 Constable, Reformation, p. 269; and see F. Bloomfield, Introduction to Thomas of Chobham, Summa confessorum, Analecta mediaevalia Namurcensia, 25 (Louvain: Éditions Nauwelaerts, 1968), p. xii, where Bloomfield suggests social changes as a reason for the movement from public to private penance, and the consquent rise in prominence of office of confessor.

15 Copeland, in Marjorie Curry Woods and Rita Copeland, 'Classroom and confession', in CHMEL, pp. 376-406 (p. 391).

16 J. W. Baldwin, Masters, Princes and Merchants: The Social Views of Peter the Chanter and His Circle, 2 vols. (Princeton, NJ: Princeton University Press, 1970), vol. 1, pp. 115-16.

17 Gary Macy, http://home.sandiego.edu/ macy/Thomas\%20of\% 20Chobham.html.

18 Chobham, Summa confessorum, 'Articulus primus', p. 6.

19 Ibid., p. 9.

20 E.g. ibid., pp. 17-20.

21 'Verbum enim diuimum omnia uulnera peccatorum sanat.' Thomas of Chobham, Summa de commendatione virtutum et extirpatione vitiorum, p. 5.

22 'Narrat enim beatus Gregorius quod cum quedam mulier esset demoniaca et adiurasset sacerdos demon ut exiret, respondit demon: facis mihi iniuriam, quia ego non introivi in hanc mulierem per me, sed ipsa me immisit in se. Ego enim sedebam in horto super lactucam, et mulier ingressa vidit lactucam illam et accepit illam sine benedictione, et comedit me simul cum lactuca', Chobham, Summa confessorum, p. 133; the exemplum is found in St Gregorius, Dialogorum libri, L.1, c.4 (PL 77.168-9); for other authors who used this exemplum, see The Exempla of Jacques de Vitry, ed. Thomas Frederick Crane, for the Folk-Lore Society (London: David Nutt, 1890), pp. 59, n. cxxx, 189, n. cxxx. It seems Peter Rabbit may have more to worry about than just Mr McGregor.

23 Chobham, Summa confessorum, p. 219.

24 'Ea propter, ut et paci et unitati tocius Ordinis provideremus, librum istum, quem librum consuetudinum vocamus, diligenter conscripsimus, in quo quatuor distincciones, tam pro rerum varietate, quam pro legencium utilitate, locis suis adnotamus', Les Statuts de Prémontré au milieu du XII e siècle, ed. Pl. F. Lefèvre and W.M. Grauwen, Bibliotheca Analectorum, Praemonstratensium Fasc. 12 (Averbode: Praemonstratensia, 1978) p. 1. 
25 'Eahte destinctiuns pet ze cleopieð dalen', AW Corpus Christi, fo. $4^{a}$ 19-20.

26 Richard H. Rouse and Mary A. Rouse, 'Statim invenire: schools, preachers, and new attitudes to the page' in Robert Benson and Giles Constable with Carol D. Lanham (eds), Renaissance and Renewal in the Twelfth Century, (Toronto: University of Toronto Press, 1991), pp. 201-25 (p. 223).

27 D'Avray, Preaching of the Friars, p. 164ff.

28 Ibid., p. 177.

29 Paul Saenger, Space Between Words: The Origins of Silent Reading (Stanford: Stanford University Press, 1997), p. 259.

30 Introduction to Jacobus de Voragine, The Golden Legend: Readings on the Saints, trans. William Granger Ryan, 2 vols. (Princeton, N J: Princeton University Press, 1993), vol. 1, p. xv.

31 Richard Hamer, Introduction to Jacobus de Voragine, The Golden Legend: Selections, trans. Christopher Stace (London: Penguin, 1998), p. ix.

32 Goering, William de Montibus, p. 65, and see pp. 61-3.

33 Bloomfield, Introduction to Chobham, Summa confessorum, p. xxv.

34 Goering, William de Montibus, pp. 71-2.

35 Rubin, 'What did the Eucharist mean?', p. 49.

\section{The rhetoric of preaching}

1 Morris, Papal Monarchy, p. 309.

2 See D'Avray, Preaching of the Friars, p. 20.

3 William Langland, Piers Plowman, B text, ed. Walter Skeat (London: Oxford University Press for EETS, 1869), Pass. 5, p. 80.

4 'Stephen Langton, Statutes of Canterbury', in Powicke and Cheney (eds), Councils and Synods, p. 31.

5 Canon 18 of Third Lateran Council, http://www.piar.hu/ councils/ecum11.htm, translation taken from Decrees of the Ecumenical Councils, ed. Tanner.

6 'Sane metropolitana ecclesia theologum nihilominus habeat, qui sacerdotes et alios in sacra pagina doceat et in his praesertim informet, quae ad curam animarum spectare noscuntur', Con. Lat. IV, p. 240; trans. Tanner.

7 Millett, 'Pastoral context'.

8 Alexander of Ashby, De artificioso modo predicandi, in Alexandri Essebiensis Opera Theologica, ed. Franco Morenzoni, CCCM 188 (Turnhout: Brepols, 2004), pp. 52-3. 
9 Franco Morenzoni, 'Introduction générale' to Ashby, Opera theologica, pp. xiii-xiv.

10 'In omni verbo quod procedit de ore Dei', Con. Lat. IV, p. 239.

11 D'Avray, Preaching of the Friars, p. 150.

12 'Predicatio est thematis assumptio, eiusdem quod thematis divisio, thematis divisi subdivisio, concordantiarum congrua co[nsul]tatio et auctoritatum adductarum clara et devota explanatio.' John of Wales, University College Oxford, MS 36, fo. $127^{\mathrm{ra}}$, quoted and trans. by H. L. Spencer, 'Middle English sermon', in Beverly Mayne Kienzle (ed.), The Sermon, Typologie des Sources du Moyen Âge Occidental, Fasc. 81-3 (Turnhout: Brepols, 2000), pp. 597-660 (p. 604).

13 Michèle Mulchahey, 'First the Bow is Bent in Study ...' Dominican Education before 1350, Studies and Texts, 132 (Toronto: Pontifical Institute of Mediaeval Studies, 1998), pp. 400-2.

14 Nicole Bériou, 'Les sermons Latin après 1200', in Kienzle (ed.), The Sermon, pp. 363-447 (p. 370).

15 Thomas of Chobham, Summa de arte praedicandi, ed. F. Morenzoni, CCCM 82 (Turnhout: Brepols, 1988), Cap. 7, p. 268.

16 Ibid., Cap. 1, p. 15.

17 Chobham, Summa de commendatione virtutum, Cap. 5.6, 'De accidia', pp. 230-1.

18 Baldwin, Masters, Princes and Merchants, vol. 1, pp. 17-18.

19 Chobham, Summa de arte praedicandi, p. 284.

20 James J. Murphy, Rhetoric in the Middle Ages: A History of Rhetorical Theory from St. Augustine to the Renaissance (Berkeley: University of California Press, 1974), pp. 303-17.

21 Chobham, Summa de arte praedicandi, p. 285.

22 Goering, William de Montibus, p. 261.

23 Trans. Phyllis B. Roberts, 'The Ars praedicandi and the medieval sermon', in Carolyn Muessig Preacher, Sermon and Audience in the Middle Ages (Leiden: Brill, 2002), pp. 41-62 (p. 58); 'Arcus dicitur Christus, et propitiatio Dei, scriptura, iudicium, robur, intentio, insidie, et dolus', William de Montibus, quoted in Goering, William de Montibus, p. 268.

24 'Arcus etiam iudicium, unde: 'Vt fugiant a facie arcus' [Isaiah 21:15]; et in Lamentationibus [2: 4]: 'Tetendit arcum suum, quasi inimicus' etc. In arcu lignum solidum est potentia et fortitudo Dei nunc auersa a percussione. In die iudicii applicabitur et adaptabitur corda tunc extensa et ostensa. Hec est iustitia iaculans sagittas acutas, id est uerba, asperiora, asperima', ibid., p. 268; I am grateful to Joseph Goering for advice on this translation. 
25 Rouse and Rouse, 'Statim invenire', p. 213.

26 Jean Leclercq, The Love of Learning and the Desire for God, trans. Catharine Misrahi (New York: Fordham University Press, 1961), pp. 73-4.

27 'Adeo diuinis exercitatus in litteris ut omnem materiam uerbis propheticis et apostolicis decentissime explicaret. Sua namque fecerat uniuersa et uix nisi uerbis autenticis nec in sermone communi nec in exhortationibus nec in epistolis conscribendis loqui nouerat.' John of Salisbury, Memoirs of the Papal Court, trans. M. Chibnall (London: Thomas Nelson, 1956), pp. 26-7.

28 'Modo, de Bernardo. Sciendum quod modus ejus est sine modo excedens et capacitatem fere omnium ingeniorum, qui prae omnibus in omnibus dictis Scripturam inculcat ut vix sit una sua sententia quae ex auctoritate Biblia vel multis auctoritatibus non dependeat.' Robert of Basevorn, Forma Praedicandi, p. 247; 'Form of preaching', p. 131.

29 D'Avray, Preaching of the Friars, p. 9

30 Louis-Jacques Bataillon, 'Similitudines et exempla dans les sermons du XIII ${ }^{\mathrm{e}}$ siècle' in Katherine Walsh and Diana Wood (eds), The Bible in the Medieval World: Essays in Memory of Beryl Smalley, Ecclesiastical History Society (Oxford: Basil Blackwell, 1985), pp. 191-205 (p. 192).

31 Bataillon, 'Similitudines et exempla', pp. 193-5.

32 Bird, 'The religious's role', p. 227.

33 Ibid., p. 222.

34 'Melius est enim quod in appetitu audiendi adhuc dimittantur, quam prolixitate grauentur', James of Vitry, Sermones in Epistolas et Euangelia dominicalia totius anni (Antwerp: In Aedibus Viduae \& Haeredum Ioannis Stelsiij, 1575), 'Proemium D. Iacobi de Vitriaco in Sermones Dominicarum totius anni' (n.p.).

35 James of Vitry, 'Sermo in Capite Ieiunii', ibid., pp. 226-9.

36 James of Vitry, 'Eodem die thema sumptum ex Ioele Propheta' ibid., p. 229; Joel 2: 13.

37 James of Vitry, 'Dominica Prima in Quadragesima', ibid., p. 247; cf. $A W$ Corpus Christi, fo. 59 $13-21$.

38 Alan of Lille, Liber in Distinctionibus Dictionum Theologicalium, in PL 210, 759.

39 Carolyn Muessig, The Faces of Women in the Sermons of Jacques de Vitry (Toronto: Peregrina, 1999), p. 87.

40 'Unde post peccatum Ade et filiis suis injuncta est penitencia, dicente Domino: In sudore vultus tui vesceris pane tuo', 'Sermo ad agricolas', in J.-Th. Welter, L'Exemplum dans la Littérature Religieuse et Didactique du Moyen Âge (Paris: Occitania, 1927), pp. 457-67 (p. 458). 'In sudore vultus tui vesceris pane', Genesis 3: 19. 
41 Humbert of Romans, 'The gift of fear', in Early Dominicans, trans. Tugwell, p. 374.

42 'Diabolus, autem, nichil ita diligit ut mortem anime, et nichil ita odit sicut anime uitam ... Nec melius potest animam sauciare quam subtrahendo ei uitam suam, id est sermonem Dei.' Thomas of Chobham, Sermo 16, in Sermones, ed. Franco Morenzoni, CCCM 82A (Turnhout: Brepols, 1993), p. 164.

43 Chobham, Summa de commendatione virtutum, Cap. 1, p. 6.

44 Chobham quotes Gregory on the weakness of someone's habits causing injury, while the medicine of poverty provides the cure, ibid., quoting Gregory, Homila in Euangelia.

45 'In scolis metuntur herbe virentes ut excutentue in fenum spargendum postea inter oves et boves comedentes', Baldwin, Masters, Princes and Merchants, vol. 2, p. 269; and vol. 1, p. 113.

46 Mulchahey, 'First the Bow is Bent', pp. 409-14.

47 'Tertius modul tariocinari per exempla, quod multum valet laicis, qui gaudet exemplis', Basevorn, Forma Praedicandi, Cap. 39, p. 293; 'Form of preaching', p. 182.

48 'Sermo ad agricolas', in Welter, L'Exemplum, p. 466.

49 'Multi enim incitantur exemplis, qui non moventur præceptis', 'Quid est fragmenta post coenam colligere, nisi Sanctorum exempla post mortem ad memoriam revocare, ut cophini impleantur; id est pauperes \& parvuli exemplis Patrum reficiantur? Nam \& catelli edunt de micis quae cadunt de mensa Dominorum suorum', James of Vitry, VMO, p. 636.

50 Le Goff, Medieval Imagination, p. 78.

51 Beryl Smalley, The Study of the Bible in the Middle Ages, (1952; Notre Dame, IN: University of Notre Dame Press, 1964), pp. 256-7.

52 'Un récit bref donné comme véridique et destiné a être inséré dans un discours (un général un sermon) pour convaincre un auditoire par une leçon salutaire', Claude Bremond, Jacques le Goff and Jean-Claude Schmitt, L'Exemplum, Typologie des Sources du Moyen Âge Occidental, Fasc. 40 (Turnhout: Brepols, 1982), pp. 37-8.

53 Mulchahey, 'First the Bow is Bent', p. 458.

54 For an account of the medieval reportatio, see Smalley, Study of the Bible, pp. 200-7.

55 'V.g. Nonne stultus esset qui funem texeret vel faceret per quem $\mathrm{ab}$ inimico suspenderetur? Sic est qui peccatum facit quo damnetur. Funibus peccatorum quisque constringitur. Prov. $5^{\circ}$, Basevorn, Forma Praedicandi, Cap. 39, p. 293; 'Form of preaching', p. 181. 

(Oxford: Oxford University Press, 1990), p. 5.

57 Smalley, Study of the Bible, p. 244.

58 Marcia L. Colish, The Mirror of Language: A Study in the Medieval Theory of Knowledge (New Haven: Yale University Press, 1968), p. vii.

59 Spencer, English Preaching, p. 81.

\section{Beguine sermons}

1 Gunn, 'Private meditations and public discourse'.

2 Bériou, 'La prédication'.

3 Hubert of Sorbonne, Sermon 15, ibid., 208.

4 Ibid., p. 209.

5 'Unde recte sumus sicut puer qui, quantumcumque pro utilitate sua uerberetur, tamen plorat. Sic nos semper ploramus, et displicet nobis quando ipse Deus nos uerberat', ibid., pp. 208-9.

6 'Uis ire ad tabernam respice finem! Finis est quod forte espendes ibi una hora quidquid lucratus fuisti tota ebdomada. Sed adhuc peius, quia bibis nimis, et inde occides caput tuum. Et plus, quia inde dices uilloniam alicui qui ti ibi interficiet, et tu es in peccato mortali.' Nicolas de Gorran, Sermon 31, in Bériou, 'La prédication', p. 226.

7 'Sur 56 sermons, 20 ont été prêchés par des dominicains, 18 par des maîtres séculiers, 15 par des franciscains, et les trois derniers par des chanoines réguliers', ibid., p. 162.

8 See Muessig, Faces of Women, for translations of and commentaries on these sermons. The 'Second Sermon to Virgins and Young Girls', from the Sermones ad status, is found at pp. 88-93, and is the 'Second Sermon to the Virgins' referred to by Brenda Bolton, 'Thirteenth-century religious women: further reflections on the Low Countries "special case" in Dor, Johnson and Wogan-Browne (eds), New Trends in Feminine Spirituality, pp. $129-57$ (p. 141).

9 Penny Galloway, "Life, learning and wisdom": the forms and functions of beguine education', in George Ferzoco and Carolyn Muessig (eds), Medieval Monastic Education (London: Leicester University Press, 2000), pp. 153-67 (pp. 158-9).

10 Bériou, 'La prédication', p. 182.

11 'Qui préfèrent d'ailleurs insister sur la préparation le l'âme a la vie mystique, plutôt que sur l'union mystique elle-même', ibid., p. 196. Bériou notes that, in this moderation and prudence, these 
sermons are very different from those preached by Master Eckhart and his disciple Tauler, p. 196, n. 310.

12 McDonnell, Beguines and Beghards, pp. 224-7.

13 Bériou, 'La prédication', pp. 179-80; Warren, Anchorites and their Patrons, p. 25.

14 Bériou, 'La prédication', pp. 184-5, quoting Sermon 32: 'Qualis sponsus talis debet esse sponsa nigra in carne per penitentiam sicut sponsus in cruce per passionem et tribulationem', p. 185, n. 251. For Julian of Norwich's vision of the Passion of Christ, chap. 16 of 'A Revelation of Love', The Writings of Julian of Norwich, ed. Nicholas Watson and Jacqueline Jenkins (Pennsylvania State University Press, 2006), p. 179.

15 Hubert of Sorbonne, Sermon 15, 'Ad beginas in festo beati Iohannis in mane', in Bériou, 'La prédication', pp. 202-11.

16 'In hoc verbo duo notantur: bellum quod processit, et premium quod fuit post', ibid., p. 203.

17 'Primum bellum est contra temptationes, secundum contra tribulationes, tertium est quod sequitur ex uictoria duorum primorum, scilicet ascendere in contemplatione', ibid., p. 204.

18 'Specula est ipsa conscientia, uel sancte meditationes', ibid., p. 204.

19 'Halie meditatiuns . . . ant angoisuse bonen', $A W$ Corpus Christi, fo. $65^{\text {a }} 9-10$.

20 Ibid., fo. 74aff.

21 'Sic tu debes, in tua anima que est castrum a te custodiendum, ponere uictualia, scilicet panes uerbi Domini, et exemplorum sanctorum Patrum ad sustendandum [sic] et nutriendum sanctas et uiriles meditationes, et in constantia roborandas.' Hubert of Sorbonne, Sermon 15, in Bériou, 'La prédication', p. 205.

22 ' Det tresor pet, beo hit eanes forloren, ne bið hit neauer ifunden', 'Hali Meiðhad', in Millett and Wogan Browne (eds), Medieval English Prose for Women, p. 8, trans. p. 9.

23 AW Corpus Christi, fo. $44^{\mathrm{b}} 10$.

24 'Golt-hord is goddede, pe is to heouene ieuenet for me hit buð perwið; ant pis golt-hord, bute hit beo pe betere ihud ant iholen, his is forlore sone, for as Sein Gregoire seið, Depredari desiderat qui thesaurum puplice portat in uia: pe bereð tresor openliche $\mathrm{i}$ wei pet is al ful of reaueres ant of peoues, him luste leosen hit antbeon irobbet.' Ibid., fo. 41 a $16-21$.

25 'Plures erunt saluati quam ceciderint de demonibus, se de uirginibus solis replebuntur sedes de quibus ceciderunt demones', Hubert of Sorbonne, Sermon 15, Bériou, 'La prédication', p. 206 ; cf. AW Corpus Christi, fo. 44 ${ }^{\mathrm{b}} 8-10$.

26 'Engel and meiðen beoð euening i uertu i meiðhades mihte, hades mihte, pah eadinesse ham twinni zetten ant totweame', Millett 
and Wogan Browne (eds), Medieval English Prose for Women, pp. 10-11.

27 Carolyn Muessig, 'Paradigms of sanctity for thirteenth-century women', in Models of Holiness in Medieval Sermons, Textes et Études du Moyen Âge, 5 (Louvain-la-Neuve: Fédération Internationale des Instituts d'Études Médiévales, 1996), pp. 85-102 (p. 98).

28 For example, at $A W$ Corpus Christi, fo. 98 ${ }^{\mathrm{b}}$ 17-21.

29 'Quia ibi pugnat homo tantum per suam deuotionem contra suam pigriciam, quod ipse eleuat naturam suam super se ipsum' (since man there fights as much through his devotion against his indolence, because he raises his own nature above himself), Hubert of Sorbonne, Sermon 15, Bériou, 'La prédication', p. 209; Hubert uses the term homo as non-specific human being.

30 Bernard of Clairvaux, 'In Quadragesima Sermo Sextus', in S. Bernardi Opera, ed. J. Leclercq et al., vol. 1 (Rome: Editiones Cistercienses, 1966), p. 378; trans. as Appendix to Ancrene Wisse Parts Six and Seven, ed. Geoffrey Shepherd ([1959] rev. edn. Exeter: University of Exeter Press, 1991), pp. 71-2; see discussion of Ancrene Wisse's use of this sermon in part III.

31 'Qui préfèrent d'ailleurs insister sur la préparation de l'âme à la vie mystique, plutôt que sur l'union mystique elle-même', Bériou. 'La prédication', p. 196.

32 'Si esset suspensa in medio aere', Hubert of Sorbonne, Sermon 15, in ibid., p. 210.

33 'Scilicet quando non cogitat nec uult cogitare nisi de Deo et celestibus, tunc est in cruce cum Christo suspensus. Iste est bonus miles, et bene deuicit istud bellum', ibid., p. 210.

34 'Ego ducam eam in solitario loco, et ibi familariter loquar ad cor eius ad consilium, et replebo eam, et lactabo de dulcedinibus meis ei ostendendo. Et hoc fit specialiter hiis qui sincere stant et intrauerunt in religione, et etiam quibuscumque dulciter de eo meditantibus. Unde dicit sancta anima sponso suo: Dilectus meus michi, et ego sibi', ibid., p. 211.

35 'Les images qui peuplent l'esprit et le discours des prédicateurs sont aussi quelquefois celles qui figurent sur les murs et sur les vitraux des sanctuaires', Bériou, 'La Prédication', p. 190.

36 'Tout cela est dit dans une langue simple, concrète et imagée', Bériou, 'La prédication', p. 190.

37 'Templum magistra beguinarum de dedicatione ecclesie' in ibid., p. 200.

38 'Et hee sunt cruces que fiunt extra. Intra, scilicet memoria Passionis quam in corde anima sancta semper debet habere', ibid., p. 200. 
39 See the exploration of this similitudo in Jocelyn Price [WoganBrowne], "Inner" and "Outer": conceptualizing the body in Ancrene Wisse and Aelred's De Institutione Inclusarum', in Gregory Kratzmann and James Simpson (eds), Medieval English Religious and Ethical Literature: Essays in Honour of G. H. Russell (Cambridge: D. S. Brewer, 1986), pp. 192-208 (pp. 200-2); and see discussion of this article in chapter below, on the rhetoric of Ancrene Wisse.

\section{Pastoral literature}

1 Vices and Virtues: A Middle-English Dialogue of about 1200 A.D. ed. with trans. from the Stowe MS 240, ed. F. Holthausen, EETS 89 (London: Trubner, 1888). See Frances Lee Utley, 'Dialogues, debates and catechisms', in A Manual of the Writings in Middle English 1050-1500, vol. 3 (Newhaven, CT: Connecticut Academy of Arts and Sciences, 1972), pp. 669-745 (p. 702), and Thomas Hahn, 'Early Middle English', in CHMEL, pp. 61-91 (p. 81).

2 Barratt, 'Small Latin?', p. 65.

3 J. A. W. Bennett, in Douglas Gray (ed.), Middle English Literature (Oxford: Clarendon Press, 1986), p. 263; and see previous discussion of Lambeth Homilies.

4 Chobham, Summa confessorum, p. 23.

5 Pierre J. Payer, Introduction to Raymond of Penyafort, Summa on Marriage (Toronto: Pontifical Institute of Mediaeval Studies, 2005), p. 1; Introduction available at http://www.pims.cal $\mathrm{pdf} / \mathrm{mst} 41$.pdf.

6 Raymond Creytens, 'Les constitutions des frères prêcheurs dans la redaction de S. Raymond de Peñafort (1241)', in Archivum Fratrum Praedicatorum, 18 (1948), 5-68.

7 Ibid., 7; Creytens seems to be drawing a distinction between the laws added by Pennaforte and the customs established under Jordan.

8 Payer, Introduction to Summa, p. 1. This Summa de poenitentiae was circulated with the later Summa de matrimonio, which constitutes its fourth book: Raymond de Penaforte, Summa de poenitentiae (Rome, 1603; facs. Farnborough: Gregg Press, 1967).

9 Morton Bloomfield, The Seven Deadly Sins: An Introduction to the History of a Religious Concept, with Special Reference to Medieval English Literature (Michigan State College Press, 1952), p. 124 and cf. John Fleming, 'The friars and medieval English literature', in CHMEL, pp. 349-75 (p. 357). 
10 Newhauser, Treatise on Vices and Virtues, pp. 124-7.

11 Antoine Dondaine, 'Guillaume Peyraut: vie et œuvres', Archivum Fratrum Praedicatorum, 18 (1948), 162-236 (186).

12 Ibid., 169.

13 Ibid., 187-8.

14 'Nec diabolus, nec homo malus, nec infirmitas, nec mors, nec alia aduersitas potest ei nocere, si a peccato cauerit sibi', Peraldus, Summa virtutum ac vitiorum, 2 vols. bound in 1 (Moguntia, 1618), vol. 2, p. 1.

15 An outline of the Summa is given in 'The Peraldus Project', at http://www.english.upenn.edu/\%20 swenzel/peraldus.html.

16 'Aspectus mulierum valde timendus est, ut potest ostendi \& authoritatibus \& exemplis \& rationibus.' Peraldus, Summa, p. 24.

17 'Ant nim per-of zeme pet tis uuel of Dyna com nawt of pet ha seh Sichen, Emores sune, pet hat sunegude wið, ah dude of pet ha lette him leggen ehnen on hire', AW Corpus Christi, fo. $14^{\mathrm{a}}$ 28 -fo. $14^{\text {b }} 2$.

18 'Alswa Bersabee, purh pet ha unwreah hire i Dauiðes sihðe, ha dude him sunegin on hire', ibid., fo. $14^{\mathrm{b}} 4-5$.

19 'Ecce laqueus in vertice', 'Beware of the trap at the top of her head' (referring to her hair), and 'Fouea autem profunda est meretrix', 'But a whore is a deep pit', Peraldus, Summa, p. 24.

20 AW Corpus Christi, fo. 52a 25.

21 Bloomfield, Seven Deadly Sins, p. 148.

22 Richard Newhauser, Introduction, Richard Newhauser (ed.), In the Garden of Evil: The Vices and Culture in the Middle Ages (Toronto: Pontifical Institute of Mediaeval Studies, 2005), pp. vii-xix (passim, esp. pp. xii-xiii). I am grateful to Richard Newhauser for helping me clarify these ideas, and for using the term 'habitual categories' in personal correspondance.

23 'Liun of prude, neddre of attri onde, vnicorne of wreaððe, beore of dead slawde, vox of zisceunge, suhe of ziuernesse, scorpiun wið pe teil of stinginde leccherie, pet is, galnesse', $A W$ Corpus Christi, fo. $52^{\text {a }} 22-4$.

24 Bloomfield, Seven Deadly Sins, p. 151.

25 Copeland, 'Classroom and confession', p. 397.

26 Newhauser, Treatise on Vices and Virtues, pp. 55, 167.

27 Fleming, 'Friars', p. 358.

28 C. H. Lawrence, 'Cantilupe, Walter de (c.1195-1266)', H. C. G. Matthew and Brian Harrison (eds), Oxford Dictionary of National Biography (Oxford: Oxford University Press, 2004; accessed from http://www.oxforddnb.com/vieww/article/3571, 13 Feb. 2006). 
29 Powicke and Cheney (eds), Councils and Synods, vol. 2, p. 887. See Copeland, 'Classroom and confession', p. 396.

30 Powicke and Cheney (eds), Councils and Synods, vol. 2, pp. 900-4. This is the same order as that in which the sins are found in Part Four of Ancrene Wisse.

31 'Amarissimum antidotum', Jerome, Commentarii in Isaiam, Bk. 14, PL 24. 491.

32 Hubert of Sorbonne, Sermon 15, in Bériou, 'La prédication', pp. 202-11 (p. 208).

33 'Hu mei pe leche pe lechnien pa hwile pet iren sticat in pine wunde. Nefre. Ne pu ne mizt beon wel iscrifen god almihti to cweme. bute pe heo alle for-lete eiðer ze pa ane ze pa oðer.' Old English Homilies, ed. Morris, p. 23. 


\section{Part III}

Ancrene Wisse: text and context 



\section{0 \\ The rhetoric of Ancrene Wisse}

Ancrene Wisse either quotes from, or uses the same sources as, Thomas of Chobham, Odo of Cheriton, James of Vitry and Alan of Lille, and in its use of modern rhetorical devices and neologisms adapted from Latin or French, this thirteenthcentury English text was innovative and at the cutting edge of pastoral literature. Many of the pastoral ideas and rhetorical methods that were developing in Paris in the late twelfth and early thirteenth centuries are found in Ancrene Wisse. In order to make penitential and contemplative spirituality available to a largely lay audience, and democratize a spirituality that had been the province of monasticism, the author uses the methods of preaching to lay people. We need to examine how the author of Ancrene Wisse used and adapted the rhetoric associated with the Latin pastoralia that was developing in the late twelfth and thirteenth centuries, and in doing so instigated a new, vernacular pastoral literature in England that was to blossom in the late fourteenth century.

\section{i. Structure}

The most immediately obvious use of Latin rhetorical models in Ancrene Wisse is its division into destinctiuns, a term derived from the Latin distinctiones. Ancrene Wisse uses the term destinctiun in the sense of a chapter division; the author is quite self-conscious in his use of a term that may not be familiar to his readers: 'Now, my dear sisters, I am dividing this book into eight 'destinctiuns', which you call parts' ${ }^{1}$ The role of distinctiones in dividing long works has been mentioned, as has the structural use of biblical distinctiones which were also a form of scholastic exegesis, giving the figurative meanings of a single word supported by biblical 
references. Distinctiones are used for the sake of clarity, for ease of access, and to make the reading more interesting. In Ancrene Wisse the term destinctiun is used in the sense of division, and division and subdivision is an important rhetorical device throughout the work. Rhetoric has been described as 'purposeful language', ${ }^{2}$ and in Ancrene Wisse the use of divisions promotes the purpose of the work - to persuade and teach the anchoresses, who were its primary audience, and the wider, more general audience for whom it was also intended. The use of divisions should therefore be considered an essential aspect of its rhetoric.

The stated division of the work into destinctiuns recalls the prologue of the Prémontré statutes, which points to the division of the statutes into distinctiones, ${ }^{3}$ a division that itself was modelled on that of the Decretum of Gratian. ${ }^{4}$ The Dominican constitutions, which are dependent on those of Prémontré, are divided into two distinctiones, and the possible authorship of Ancrene Wisse by a Dominican offers a route of transmission for this style of division. The author of Ancrene Wisse insisted on clarity and orderliness in writing, as he insisted upon orderliness and unity among the women for whom he was writing; he quoted, as did the prologues of both the Premonstratensian and Dominican constitutions, a verse from the Acts of the Apostles: 'Multitudinis credentium erat cor unum et anima una', 'The multitude of believers had one heart and one soul'.5 The constitutions of the Dominican order were dependent on the Premonstratensian consitutions, but the Dominican ones were divided into just two distinctiones, the contents of which are listed in the prologue. ${ }^{6}$

Thirteenth-century ideas of division and subdivision associated with the rhetoric of pastoralia are also used in some of the individual parts of Ancrene Wisse, especially in those parts that are most relevant to a more general lay audience. Part Five, which is on confession and is 'relevant to everybody alike', 7 shows most evidence of this pattern of hierarchical division; the schematic listing of the sins which allows a full and complete account of the temptations that must be resisted is achieved through division and subdivision. Part Five forms a trilogy with Parts Four and Six, dealing with contrition, confession and penitence. Parts Four and Five in particular 
show the influence of contemporary pastoral literature in their construction as well as their material; Part Six, however, deals not with types of penance, but with the penitential life as lived out by the anchoresses. The style of this part differs significantly from the style associated with pastoral literature, adapting a more monastic mode. The relationship between the functions of the different parts of Ancrene Wisse and their particular rhetorical styles needs to be the focus of an examination of the rhetoric of Ancrene Wisse - and should shed light on the function and anticipated readership of these parts.

Structural organization is important in Ancrene Wisse, but each part is organized differently, depending on the kind of material and the intention of the part. A number of scholars have tried to discern structural patterns for various parts of Ancrene Wisse, with varying degrees of success. ${ }^{8}$ The structure of Parts One and Eight is largely dictated by the pragmatic nature of those parts; Roger Dahood suggests that, although there is an 'impression of looseness', this is partly due to the lack of clear signalling of subordination in the manuscripts, and that there are 'logical divisions in the text'. ${ }^{9}$ Dahood also claims that the author was concerned to make the structure clear by means of coloured initials and other division markers; unreliable copying led to the inconsistent manuscript divisions in the various surviving versions of the text. ${ }^{10}$ The list of material to be covered in Part Eight that is provided in the Preface also offers a plan of the order in which these topics are to be covered. ${ }^{11}$ It is more difficult to discern structural patterning in those parts, like Part Six, that deal specifically with the nature of anchoritic spirituality. Parts Three and Seven both have a loose structure that may be compared to monastic discourse, but in Part Two there is a clear pattern of organization which, while not using a hierarchical structure, does employ division as a way of organizing material.

Part Two offers a theme in Latin from the Scriptures, ${ }^{12}$ but, unlike a 'modern' sermon, it does not divide this theme to provide its development and structure; instead, the five senses provide the structural form of the part, forming the five 'chapters' announced in the Preface. ${ }^{13}$ Alexandra Barratt comments that the structure of Part Two is 'complex and marked by a divergence between the author's stated plan and 
the actual text'; she suggests that this confusion arises 'directly from the ambiguity of his terminology'. ${ }^{14}$ Some of the complexity is due to an important diversion from the stated plan, when the author addresses the anchoresses and the nature of their spirituality directly. Much of Part Two would be relevant to anyone wishing to follow a devout Christian life: any woman could be considered guilty of tempting a man into the pit of sin with 'her fair complexion, her white neck, her roving eyes'; $;^{15}$ the indictment of backbiting and flattery with its strong language ${ }^{16}$ is not particularly relevant to the situation of anchoresses, although they are warned against gossip as a form of sinful talk, ${ }^{17}$ and the author acknowledges that 'All this last part about the ear is relevant to the anchoress'.$^{18}$ Listening to such talk comes under the heading of the sense of the ear; so far the author has made the distinctions, and the way in which he intends to proceed, very clear. The first sense discussed is that of the eye; he then proceeds to the mouth, commenting, 'Speech and taste both belong to the mouth, as sight does to the eye; but we will leave taste until we discuss your food, and talk now about speech, and later about hearing - sometimes about both combined, since they go together. ${ }^{19} \mathrm{He}$ is clearly keen that his reader is following, and frequently points out the direction he is following, linking the senses as he deals with them: 'So far your silence has been discussed . . . Now I shall say something about your hearing,. ${ }^{20}$ And having discussed these three organs separately, he signals his intention to talk about them all together: 'Sight, speech, and hearing have been discussed separately in turn; let us now turn back and talk about them all together. ${ }^{21}$ At this point, however, the orderly progression of the argument is disrupted and there is a lengthy passage about the role of sight in the contemplative life. ${ }^{22}$ In inspiration and style, this passage owes more to Bernard's sermons on the Song of Songs than thirteenth-century sermons to the laity. The author has not, however, forgotten his overall plan, and announces, 'Now I have discussed three of the senses; let us now briefly discuss the two others. ${ }^{23}$ This provides the occasion for a discussion on the suffering of Christ on the cross through all his senses, and a reminder to the anchoress that her renunciation of the world must be 
measured against the suffering of Christ. In conclusion, a severe warning is addressed to the sisters to avoid $\sin ,{ }^{24}$ but then the author announces that enough has been said about the five senses, and with a reminder of the theme, 'Omni custodia custodi cor tuum', he moves on to the third Part. ${ }^{25}$

In Parts Three and Seven, the composition is largely determined, not by divisiones but by patterns of imagery and lengthy similitudines and forbisnes, which play a constructive as well as illustrative role. The Preface claims that: 'The third part is about birds of a particular kind which David compares himself to in the Psalter as if he were a recluse, and how recluses are similar in nature to those birds. ${ }^{26}$ This may seem a bizarre subject, but Part Three takes as its thema verses from Psalm 102: 'I am like a pelican of the wilderness: I am like an owl of the desert. I watch, and am as a sparrow alone upon the house top.' These verses were used in sermons of the period addressed to religious, as well as in sermons of Aelred of Rievaulx. ${ }^{27}$ Part Three of Ancrene Wisse develops by means of a series of comparisons between the anchoress and the three birds, the qualities of the pelican, night-bird (nycticorax) and sparrow being taken to describe the ideal of the anchoritic life. Digressions and diversions, exempla and authorities abound, but the author keeps coming back to his theme of the ways in which the anchoress is like a bird: structural form and unity is achieved by the comparison of the anchoress with birds.

There is also a sub-theme, using verses from the Gospels, that refers to birds: 'the foxes have holes, and the birds of the air have nests'. ${ }^{28}$ The description of Part Three of Ancrene Wisse provided by Anne Savage and Nicholas Watson is very like that of a 'modern', that is, thirteenth-century, sermon:

$[\mathrm{P}]$ art III has as its point of departure and return a single key text, in this case two verses of Psalm $101 \ldots$ the whole part is dedicated to stage-by-stage exposition of this text, with the assistance of other texts and biblical exempla... The transitions between one section and another are all marked by a return to it and the introduction of a new topic derived from it. There are five main sections . . . each based on characteristics of one of the birds mentioned in the text - the pelican, the nycticorax and the sparrow - which are seen as representing both good and bad kinds of anchoritic behavior. ${ }^{29}$ 
But in this part, the theme is not divided by means of the distinctiones found in university sermons, but is elaborated through the use of extended metaphors, developed from the similes provided by the thema. The lengthy similitudines consisting of chains of comparisons - how the anchoresses are like birds - is similar to the description Bataillon gives of a sermon directed at a lay audience. ${ }^{30}$

There is also some of the numbered orderliness that is a feature of Ancrene Wisse: the necessary solitariness of the anchoritic life is supported by a very orderly list of the eight reasons why you should be attached to the solitary life. ${ }^{31}$ From the third reason onwards, these are introduced, in the Corpus Christi 402 manuscript, in similar fashion with an enlarged capital: 'De pridde reisun, 'De foerðe reisun', 'De fifte reisun', and so on. These initials, with their flowing tails, occupy the whole of the left-hand side of the page, making what is one of the most notable pages in the manuscript. ${ }^{32}$ These reisuns are listed after the forbisnes that have been given of why you should be attached to the solitary life. The author, clearly aware of the different devices for persuasion at his disposal, appeals both to the reason and to the imagination. The imagination responds to the rich pattern of images from the New Testament and figures - including Judith and Esther - from the Old that are interwoven to provide an ideal of the anchoritic life. ${ }^{33}$ The plan is like that described by Leclercq, as it 'follows a psychological development, determined by the plan of associations, and one digression may lead to another or even to several others'; such a plan may not be 'fixed upon in advance', ${ }^{34}$ and yet even this part of Ancrene Wisse reveals a strong sense of control. The author is always able to bring his text back to his theme, concluding with a reference to Esther, who is not only hidden but also elevated, ${ }^{35}$ and a further attribute of the sparrow, which has the falling sickness.

Part Four consists largely of a systematic treatment of the seven deadly sins, and its structure is similar to that of Latin sources dealing with the sins, both patristic and more contemporary - the importance of thirteenth-century summae on the sins, such as those by Pennaforte, Peraldus and Lorens of Orleans, has been mentioned. It should be remembered, 
however, that, while Pennaforte's summa was probably contemporary with Ancrene Wisse, the others are later: none can be considered a model for the English work. Newhauser gives an analysis of the structure of a Middle English treatise on the vices which is typical of the genre: for each vice a description, list of its progeny and remedy is given. Newhauser comments:

A hierarchic pattern emerges explicitly in the microstructure with the inventory of the vices' progeny and is contained implicitly in the characterizations of the vices by what frequently amounts to their genera ... In the macrostructure a metaphorical organization of the material is supplied by the view of the vices as a broad path to hell. ${ }^{36}$

In Part Four of Ancrene Wisse, the macrostructure is provided by the theme of the temptations faced, not only by the anchoresses, but by anyone in the world wishing to lead a pious life. The sins these temptations lead to are allegorized as beasts, each with its own foul offspring, while remedies for the sins are dealt with together under the theme of 'how all the seven deadly sins can be driven away by firm faith'. ${ }^{37}$ Although the association of sins with animals is ancient, Ancrene Wisse is 'the first work in English which portrays the Sins as animals'. ${ }^{38}$ The very fact that it was in English is important, since it made such a treatment of the sins accessible and not confined to clerical readers - a treatment which is also seen in the fourteenth century in Chaucer's 'Parson's Tale', as well as in translations of the Somme le Roy, such as the Book of Vices and Virtues. ${ }^{39}$

The author's intention to proceed by means of division is signalled close to the beginning of Part Four: 'Understand then first of all, dear sisters, that there are two kinds of temptation, two kinds of trial, external and internal, and both are of many kinds. ${ }^{30}$ The division into two kinds of temptation is followed by other kinds of division: inner temptations are divided into two groups, physical and spiritual, which together constitute the seven sins. The author explains these two groups, 'physical, as from lechery, from gluttony, from sloth; spiritual, as from pride, from envy, and from anger, also from avarice. So the internal temptations are 
the seven capital sins, and their foul offspring. ${ }^{41}$ Bloomfield refers to these two groupings as 'the familiar two groups, carnal and spiritual', ${ }^{42}$

Other divisions include four categories of temptation, as found in the Psalter, a list of nine comforts against temptation, remedies against temptation, and remedies for sins. ${ }^{43}$ Even the illustrations (forbisne) themselves are numbered, though there is some confusion over this: in a series of illustrations of the importance of the constancy of love, the author announces, 'The seventh illustration is this, if you are counting correctly', but careful and correct counting shows this to be only the fifth. ${ }^{44}$ Other divisions are subdivided; for example, the sixth of the nine comforts includes 'six reasons why God sometimes withdraws himself for our good'. ${ }^{45}$ The multiplying levels of division, richly illustrated at every level, add to the inclusivity of the treatment of the sins.

Nor does this inclusivity lead to impersonality: imposed on the basic structure of Part Four, that is, the allegorical representations of the temptations faced by anyone in the world, is the more personal story of the battle between the anchoress and the devil. It is a mark of the professional artistry - and pastoral concern - of the author that he is able to use the standard form of a summa on the vices and make it relevant to a particular audience. The particular audience of the anchoresses is reminded at the beginning that their exalted life does not render them immune from temptation; indeed, they should be particularly aware of the dangers of temptation, since 'the higher the hill, the stronger the wind is against it'. Lest there be any mistake about the meaning, this metaphor is explained: 'The higher the hill of holy and exalted life, the stronger and fiercer are the devil's blasts against it, the winds of temptation. ${ }^{36}$ This is the pattern in which this part proceeds: division and subdivision provides the structure, while similes and exempla illustrate and enrich the meaning at every level. The presence in the text of two audiences - the anchoresses and an anticipated, more general lay audience also contribute to its form.

Having given a list of the seven sins, characterizing them as animals, and after the further metaphor of the retinue of the devil's court, the author directly addresses the anchoresses, 
assuring them that they are far removed from such sins. ${ }^{47}$ At this point, the author discusses the specific temptations of the anchoritic life by means of a forbisne, or analogy. Jesus Christ is as a husband to the anchoress: he will treat her gently at first but, when he is certain of her love for him, will act harshly towards her, to reprove her and test her, finally rewarding her with great happiness. The comment on this analogy - 'If Jesus Christ, your husband, does this kind of thing to you, my dear sisters, do not be at all surprised ${ }^{\prime 48}$ - is addressed specifically to the anchoresses. This analogy is supported by a scriptural one, that of God leading his people out of Egypt, but the text then returns to the methodical use of division by listing categories of temptation, based on a verse from Psalm 91. The author is aware of the framework for a discussion on sin and temptation, provided by Latin texts on the vices, but makes such material his own by not being afraid to divert attention to specific concerns. When a theme seems particularly relevant to the anchoresses, the author addresses them directly, disrupting the order of the treatise.

Part Five, which is on confession, is relevant to everyone alike, and the author does not address his dear sisters in particular until the end, when he adds a 'short final section'49 for their special use, in which he deals with how, and what, a recluse should confess. The main part of Part Five, prior to this final section, is closely related to pastoral works designed for a lay audience, and is able to keep closely to the schematic structure of such works. It uses the formalized theme of the 'conditions of confession', which was a popular tool for preachers and confessors to the laity in their efforts to educate and reform. Millett points out that examples of confession dealt with in this manner began to appear in the twelfth century, 'at first mainly in sermons, later in other works with a primarily pastoral orientation', and that the use of the formalized theme of conditions of confession 'spread rapidly after the Fourth Lateran Council of 1215, ${ }^{50}$ That this material is adapted from Latin pastoralia is indicated by the self-conscious use of technical Latinate terms, introduced into English for the first time: 'are ahne conscience' is glossed as 'pet is, ure inwit', while circumstances is referred to as a Latin word, they can be called 'totagges' in English. ${ }^{51}$ These are 
specific concepts to do with the nature of confession as it was understood by contemporary theologians; the fact that they have been translated into English, together with the emphasis placed on the penitent's own conscience, suggests those reading it were expected to take some responsibility for their own confession. This is information taken from the domain of clerical readers and adapted for lay readers of the vernacular.

The structure is also that found in clerical works: much of Part Five is taken up with the exposition of sixteen 'conditions of confession', which are each dealt with in order:

Confession must be accusatory, bitter with regret, complete, naked, frequently made, prompt, humble, made with shame, fear and hope, discreet, truthful, and voluntary, one's own, resolute and well thought out beforehand. Now these are, as it were, sixteen sections which are linked with confession, and we will say something separately about each one. ${ }^{52}$

There is thus a clear indication of how this part is to proceed, while the careful division ensures that everything that should be confessed is covered, so allowing the confession to be complete and thorough: the rhetoric has a practical application. The initial S of 'Schrift' as it introduces each condition is enlarged and decorated, ${ }^{53}$ emphasizing the divisions and making the section particularly easy to use and refer to; the sections have indeed been broken up like bread for children.

Under the heading that confession should be naked, six 'circumstances' are given which could conceal the sin; these circumstances are person, place, time, manner, number and cause. ${ }^{54}$ Each one is dealt with separately, an explanation and example of each circumstance being given. Announcing the divisions in advance in this way made the text more accessible, easily followed and easily remembered. Mnemonic verses were often used to aid the memory, and also as a 'practical method of organization' for the lists. ${ }^{55}$ Advice is given as to how this part is to be used: 'Begin first at pride and go through all its branches as they are listed above, to see which might apply to you.' ${ }^{56}$ The 'you' addressed, however, is not necessarily the anchoress; when being advised on the 
'person' subsection of how confession should be naked, the penitent is advised to say, 'I am an anchoress; a nun; a married woman; an unmarried girl; a woman . ..'; 57 and later the text notes that: 'Each individual should give an account of his circumstances according to his condition, a man as it applies to him, a woman as it concerns her.' ${ }^{58}$ After the concluding section, dealing specifically with the confession of an anchoress, a link is made with the next part: 'After confession it is appropriate to talk about penance, that is, satisfaction; and so we have a link which leads us out of this fifth part into the sixth.' 59

Although Part Six is a member of the 'confessional trilogy', its theme of penance is directed more towards the anchoresses; it opens with a direct address to the beloved sisters: 'Everything that you have to bear, my dear sisters, is penance, and hard penance. ${ }^{60}$ That this is a new destinctiun is very marked in the Corpus Christi manuscript: the first two lines are shortened so that each ends with the word 'penitence'. ${ }^{61}$ Penitence is not only the response to contrition and confession, it is the basis for the whole life of the anchoresses; nevertheless, the alternative audience is not neglected. It is accepted in Part Six that suffering is an essential element in the life of penance, and that this is not only the privilege of religious women. The question of what good it does to inflict suffering on oneself is answered: 'Dear man and woman, God is pleased by our good. Our good is if we do what we ought. ${ }^{62}$ Man and woman, in an abstract, inclusive sense, are addressed here, but the author's more specialized readership, 'mine leoue sustren', are frequently invoked, and the awareness of the specifically anchoritic audience is reflected in the rhetoric of this part, as well as in the material adapted and directly quoted.

While Parts Four and Five of Ancrene Wisse use the strict structures based on division and subdivision which were becoming popular with the increase in artes praedicandi and other works of pastoralia at the beginning of the thirteenth century, the argument of Part Six is presented, not through hierarchical structures of division, but through a web of images of suffering and shame which both illustrate the theme of penance and constitute the argument through analogy. This 
part makes use of a looser method of construction, based on association and reminiscence, and rich with scriptural references; it is a method that one could characterize as monastic. There is a conscious allusion to monastic models; the use of Bernard's Sixth Sermo in Quadragesima, a sermon delivered to a monastic audience, has been much discussed. ${ }^{63}$ Bernard's tripartite division of monastic life is here adapted and used to apply, not only to religious, but to devout people in the world, religious and anchorites. It should be noted, however, that the adaptation of this sermon in the Corpus Christi version of Ancrene Wisse occupies only the first two folios of a part that continues over nineteen folio sides. There are a number of references to other writings by, or attributed to, St Bernard, ${ }^{64}$ and a possible reference to another contemplative writer, Adam of Dryburgh. ${ }^{65}$ The author acknowledges his debt to the Cistercian Aelred of Rievaulx, and uses his De Institutione Inclusarum as an authority when insisting on the importance of purity and chastity. ${ }^{66}$ The use of the spousal imagery of the Song of Songs, together with references to contemplative writers and to a Latin treatise for an anchoress, suggests something of the specialized - and Cistercian-inspired - spirituality to be encountered in this part. The clear division and numbering of a short section listing the 'three bitternesses' represented by the three Marys ${ }^{67}$ may owe something to the scholastic habit of division, but the main rhetorical feature of this part is the extended metaphors for the anchoritic life and spirituality, which form both its material and its structure, and evoke the peculiar state and circumstances of the anchoresses.

The form of Part Seven is also largely dictated by its rich imagery; but, as with Part Three, clear control is exerted on this imagery. Dennis Rygiel suggests that the three things that the Preface says Part Seven is about, 'purity of heart, why Jesus Christ should and must be loved, and what deprives us of his love and prevents us from loving him, 68 can provide a plan for the organization of the part itself. However, this is a plan imposed by the reader, rather than provided by the author; no outline or indication of the structure of this part is given. There is some division: three reasons are given for why Christ ought to be loved, though only the first and third 
reasons are signposted, ${ }^{69}$ and 'Four main kinds of love'70 are given in order, in a manner reminiscent of the careful ordering of Part Four. The author is keeping to his intentions as stated in the Preface, however, reiterating the subject of Part Seven at the conclusion of Part Six, 'the love which makes the heart pure'. ${ }^{71}$ Rygiel claims it is the reiteration of this subject that provides Part Seven with its structure; there is a patterning of recall and recapitulation, but to claim, as Rygiel does, that 'the key to the structure of the whole work is the structure of Part Seven'72 is to ignore the important and innovatory role the use of divisio plays in the structure of Ancrene Wisse both in the overall work and in many of the individual parts.

The important role of divisio as a method in the organization and structure of Ancrene Wisse is evidence of the influence of contemporary pastoral rhetoric. The influence of this rhetoric is also apparent at the level of dilatatio, that is, amplification, argumentation and illustration. Methods of dilatatio used in Ancrene Wisse include those of the thirteenth-century preacher; however, the use of different techniques varies between the parts. How far does the use of different rhetorical techniques for illustration and explanation reflect the varying spiritual purposes of the different parts? For example, Part Seven, which is about love, includes the forbisne of the lover knight, while Part Four, about fighting temptations, is full of metaphors about fighting and warfare. The use of the contemporary rhetorical devices, such as exemplum, as well as the more traditional forms of allegory and analogy and figures of speech, including metaphors and similes, need to be examined in turn in relation to the parts in which they occur.

\section{ii. Exempla and similitudines}

The author of Ancrene Wisse was very conscious of his use of contemporary rhetorical theory and innovatory techniques. Even in the Preface, which is largely concerned with the practical details of how the work is organized, a rhetorical turn of phrase is pointed out with the term 'antonomastice', ${ }^{73}$ and in Part Two the term ' $y[p] a l l a g e$ ' is inserted as a comment on the use of this figure of speech. ${ }^{74}$ As the author pointed to 
his own use of the term destinctiuns, so the word essample, another English neologism from the Latin exemplum, is highlighted in Part Two by its position in the sentence, following the exclamation, 'lo': 'To illustrate how his flesh was more alive than any other, $l o$, here is an essample. ${ }^{75}$ The word essample is used four times in Ancrene Wisse, once each in Parts Two, Three, Four and Six, ${ }^{76}$ and each time it introduces a short story about a man in some circumstance that would have been recognized by a contemporary audience.

Essamples tend to work as illustrations rather than as similes or analogies, but in Ancrene Wisse at least this distinction gets blurred, and short stories that could be classed as exempla are sometimes introduced by 'ase' (as) or 'ilich' (like). Joseph Mosher, who suggested that Ancrene Wisse was innovative in using exempla in the vernacular, gives examples which he terms 'narrative illustrations'. ${ }^{77}$ The common feature of the stories Mosher suggests as exempla is that they are not scriptural, but proverbial or common tales: Ancrene Wisse includes stories of a man who was married and who goes on a journey, and of a man thrown into prison - not stories directly relevant to enclosed anchoresses. The exempla in Ancrene Wisse are short stories about ordinary life to which its readers could relate; they could be about physical danger battle wounds that need to be healed or the holes in a ship through which water is rushing $^{78}$ - in order to stress the reality of moral danger and the importance of confession, that is the need to heal spiritual wounds. The use of exempla as a rhetorical device was coming to the fore in the pastoral literature of the late twelfth and early thirteenth centuries, and is used to great effect in Ancrene Wisse.

The author of Ancrene Wisse was not relying solely on Latin models for his amplificatory material; the Middle English term forbisne occurs more frequently than essample 79 and should be discussed first. In some ways, the term forbisne is similar to essample, and is often translated as example. It can mean an example of conduct, a model or pattern of virtue; it is used in this sense in Part Two - the anchoress should avoid setting a bad example, ${ }^{80}$ and take care to set a good one. ${ }^{81}$ The Virgin Mary and Christ are also set forward as forbisnes - examples. ${ }^{82}$ In Part Three, although there is one 
example of the anchoress being told that she must give strength to others 'through her forbisne and through her holy prayers', ${ }^{83}$ the term is mostly used for the example set by Christ in the wilderness - as a model of solitude to be followed by the anchoress - and for stories from the Scriptures which illustrate the importance of solitude and withdrawal from the world. ${ }^{84}$ In Part Four, the term forbisne is used more in the sense of an analogy or illustration; ${ }^{85}$ in Part Seven it is used of the lengthy allegory of Christ as a suitor. ${ }^{86}$ This allegory, which we will look at in more detail later, is also referred to as a parable, ${ }^{87}$ while Christ as the ideal husband can be described as a metaphor. The different ways in which forbisne can be translated suggests something of the difficulty of characterizing and distinguishing the various rhetorical techniques employed in Ancrene Wisse.

What constitutes an exemplum can be particularly difficult to establish. Where the term essample is used, it usually appears as an illustration of the spiritual or moral life; in Part Six, the reader is instructed to 'Pay attention to this essample', the essample, or illustration, in this case being the story of a much-loved wife who missed her husband when he was travelling. The author draws the moral:

In the same way our Lord, who is the soul's husband, who sees everything that she does although he sits on high, is very pleased that she misses him, and will hurry towards her much faster with the gift of grace, or fetch her altogether to himself, to everlasting glory and bliss. ${ }^{88}$

Exempla like this, while having a self-contained narrative, also rely on the 'allegorical mode' to function: the reader accepts the resemblance between the soul's relationship with God and a wife's with her husband. In Part Three, the essample is given of a man who is in prison and owe a huge ransom; the reader is advised to learn from it - 'cunneð pis essample'. ${ }^{89}$ Wouldn't such a man be grateful if someone threw the money for his ransom at him - even if it hit him hard against the heart? This sort of rhetorical question, expecting an affirmative answer, is also found in the exemplum given in Part Four: 'When a day for judgement has 
been fixed, surely a man is showing contempt of the judge if he breaks the truce before the day fixed. ${ }^{90}$

It may not be surprising that neither essample nor forbisne occur in Parts One or Eight, which are concerned with the more practical matters of the Outer Rule, but nor does either term occur in Part Five, the part which most closely follows the schematic pattern of a form of pastoralia. In Part Five, however, there are a series of rhetorical questions, of the same form as found in the essamples, illustrating the horror of the consequences of sinning against God as reasons why a man should be sorry for his sins. The second of these reasons is particularly blunt, suggesting the torment in hell, and addressing the sinner directly as $p u$ :

If a man were condemned, for a vicious murder, to be burnt alive or ignominiously hanged, what would he feel like? Why, you wretched sinner, when you murdered the spouse of God (that is, your soul) through mortal sin, you were condemned to be hanged on a burning gallows in the eternal fire of hell. ${ }^{91}$

Surely such an argument has much in common with an enthymeme, such as this from Part Six: 'And surely it is a stupid knight who looks for rest in the fight and ease on the battlefield? The life of man on earth is warfare; all this life is a battle, as Job testifies. ${ }^{92}$ Shepherd suggests that Part Seven is 'a tissue of persuasive enthymemes'. ${ }^{93}$

In Part Six of Ancrene Wisse there is a story of the two sick men, only one of whom was prepared to drink bitter herbal medicines to recover his health. ${ }^{94}$ The author draws an analogy with Jesus drinking a bitter drink on the cross: 'Nobody should expect to go up easily to heaven.' ${ }^{95}$ Underlying this argument is the assumption that what applies to bodily health applies also to spiritual health. Physical suffering, including that caused by disease, is used metaphorically to indicate the penance of the anchoresses, but it is also to be understood literally. Suffering, in whatever form, is a way of paying for future ease and rest in heaven; it is also a way of drawing closer to Christ, since the suffering of Christ is both an agency for redemption and a model for life in this world. The idea that suffering in this world would be rewarded in heaven - or at least would reduce time spent in 
purgatory - was not confined to those who had taken up a religious vocation, but was applicable to all devout people. It is arguable that it provided a form of social control, but it is also concomitant with the affective spirituality of the period, which was often expressed in images and stories of suffering.

Jocelyn Wogan-Browne, writing of Ancrene Wisse and De Institutione Inclusarum, suggests a distinction between exempla and similitudines:

a distinction seems maintainable (and is usually maintained in medieval usage) between the exemplum's self-contained, plotbased narrative, inserted into discourse and used for exemplary purposes, and the narrative articulation of a continuous configuration of circumstances or particular images which constitutes the more intrinsically allegorical mode of the similitudo. ${ }^{96}$

Wogan-Browne suggests that many of the images employed by Aelred in the De Institutione Inclusarum 'offer imaginative consolation for, or a perspective on, the restriction and sensory deprivation of the recluse's life: a Cistercian concern with external plainness is complemented by attention to the meditative inner eye'. ${ }^{97}$ While Aelred insists that the anchoress's cell should not be decorated, ${ }^{98}$ he does allow her to develop an imaginative inner life. Wogan-Browne claims that Aelred uses lengthy similitudines, such as the white cloths on the altar and the process by which they have been whitened, which provide a simile for cleansing the soul through confession and satisfaction, but that he does not use the kind of exempla found in Ancrene Wisse, the 'more characteristic rhetorical form' for treatises on the reclusive life being 'the analogy or similitudo'; this is appropriate for the 'highly interiorized' and static life of the anchoress. ${ }^{99}$ Although Ancrene Wisse does use Cistercian models - and indeed translates parts of De Institutione Inclusarum - the mode of rhetoric is different, as were the spiritual and material experiences of Aelred's sister and the sisters for whom Ancrene Wisse was written. In Ancrene Wisse, exempla, in the sense of popular stories, are used most often in those parts which relate as much to the following of the religious life in the world as to the interior world of the anchoresses; the 
more general reader of Ancrene Wisse lived in a world of plot and story. The 'allegorical mode' which Wogan-Browne defines as fundamental to the construction of De Institutione Inclusarum, however, is also basic to Ancrene Wisse. It seems - although this is not an absolute distinction - that those rhetorical devices with a strong narrative content, such as forbisnes and exempla, are particularly used when the purpose is to persuade the reader of a general moral truth, rather than to exemplify the specialized spirituality of the anchoress.

Lengthy similitudines and complex patterns of imagery are used in Parts Six and Seven to construct the peculiar nature of anchoritic spirituality, but even here there is evidence of the influence of contemporary pastoral rhetoric. The comparison with the suffering in pain and shame with Jesus on the cross constitutes one of the main imagistic themes in this part - the Passion of Christ. 'Pain and shame'100 are the 'hooks', to use Leclercq's term, to which the following images are linked, or woven, making up the 'fabric' of the discourse. ${ }^{101}$ Pain and shame are signified by the fiery wheels of Elijah's chariot, and by the sword of the cherub before the gates of Paradise. ${ }^{102}$ Elijah's ascent to heaven 'often received pictorial treatment' in the twelfth century, ${ }^{103}$ and the red colour that would have been associated with such pictures returns the reader to the cross of Jesus, reddened with his blood. ${ }^{104}$ The sisters can identify with Christ and draw close to him through the suffering and shame they must endure. The bitterness of the penitential life is addressed through elaborate etymology in a passage where the dear sisters are urged to pay close attention. The list of three bitternesses that are represented by the three Marys encapsulates the anchoritic life, and emphasizes its ascetic and penitential nature. ${ }^{105}$

In Part Six, the author of Ancrene Wisse is dealing with penitence within the framework of a dedicated religious life as his language and style attest - but this life itself is to be understood within the context of contemporary religious sensibility. Features of this religious sensibility, such as the emphasis placed on personal penance and the Passion of Christ as an example for that penance, are to be found in writings associated with lay piety, such as sermons, as well as 
in monastic writings, but gain a greater intensity when dealt with in the context of a dedicated religious life. The incarnational spirituality of Ancrene Wisse is evoked through images which allow the anchoress to identify with the suffering of Christ and to see him as a spouse; the association between the Passion of Christ and passionate love for him is developed further in Part Seven.

Part Seven does not use the spousal imagery derived from the Song of Songs found in Part Six, but instead the metaphor of Christ as the ideal husband attributes to him qualities similar to those found in thirteenth-century marriage sermons, as discussed by Nicole Bériou and David d'Avray. ${ }^{106}$ These are qualities found in contemporary secular literature; Jesus is presented as wooing the soul with all the qualities of a courtly knight: 'Am I not supremely handsome? Am I not the richest of kings? Am I not of the noblest ancestry? Am I not the wisest of the wise? Am I not the most courteous of men? Am I not supremely generous?'107 Bériou and d'Avray point out the social and historical interest of these images, in that they say something about the qualities valued in a husband - both in society and in the literature of the period. ${ }^{108}$ The metaphor of Christ as the ideal husband - the model of courtesy, a knight as well as a wooer - has internal coherence and is consistent with the incarnational spirituality that is at the heart of the work as a whole. In sermons to beguines in Paris in the thirteenth century, Christ is also presented as a knight, and God is 'le seigneur courtois' who treats with mercy those who are faithful to him and generous with their gifts. ${ }^{109}$

In Ancrene Wisse, the shield the knight carries is the body of Christ stretched out on the cross, ${ }^{110}$ and, by extension, the crucifix placed in church, as a knight's shield would be hung in his church in his memory, 'to be a reminder of the knightly prowess of Jesus Christ on the Cross'. 111 The imagination of the reader moves from the allegory of the lover knight, through the image of Christ on the cross likened to a shield, to the actual crucifix in the church which the anchoresses use as an aid for meditation: the cross serves as a reminder of the spiritual correlative of the asceticism of the anchoritic life. As Christ is the spouse of the virgin and his marriage-bed her reward in heaven, he is also, through his Passion, a model or 
example of the penitential life. $\mathrm{He}$ is a perfect husband because of his sacrifice on the cross: Christ as lover and Christ as redeemer become inseparable. The imagery here links this part of Ancrene Wisse both to thirteenth-century marriage sermons and to the bridal mysticism of the beguines.

The imagery of Parts Six and Seven is the expression of a spirituality in which, through her suffering and enclosure, the anchoress could identify herself with the crucified Jesus, in the hope of enjoying bliss with the resurrected Christ; the language is emotive and, at times, erotic. But this is not the whole story of the rhetoric - or the spirituality - of Ancrene Wisse. The use of the rhetoric of pastoralia, as well as the concerns for the moral and spiritual education of a wider readership than the anchoresses, establishes Ancrene Wisse as a work of vernacular spirituality within a context of lay piety. The careful division of the work, and clear indication of those divisions, meant that this work was accessible to any devout, literate person wanting to follow a religious life - whether enclosed in a cell or out in the world.

The author used the immediate experiences of his primary readership who were enclosed within the cell, and the literary tradition of monastic discourse and imagery; but the many illustrations from the Scriptures, the lives of the Fathers, romantic literature and contemporary exempla throughout Ancrene Wisse would appeal to a lay audience in the world as much as to the anchoresses. Ancrene Wisse is a work that addressed lay anchoresses while also acknowledging its wider audience of devout lay people, and the composition of the work shows the alternation between, and integration of, the concerns of these two audiences: quibus alia dicenda sunt, aut certe aliter, 'to whom different things should be said, or at least said in a different way'. It is through the rhetoric that the spirituality of Ancrene Wisse is constructed. This is true both of the more general pastoral elements and the contemplative spirituality of the anchoresses. Both pastoral and contemplative vernacular literature developed in the high Middle Ages, and the place of Ancrene Wisse in the history of this literature needs to be considered. 


\section{1 \\ Ancrene Wisse: asceticism \\ and contemplation}

The spirituality of the anchoresses was affective and contemplative: the anchoresses sought to approach God through the humanity of Christ. Affective piety, often expressed in devotions accessible to lay people, developed in the high Middle Ages and was expressed in works of vernacular spirituality. The spirituality of Ancrene Wisse, however, is not identical with that of the anchoresses; it is the spirituality of a text that could be read by, and be a lesson for, a more general lay readership. The function of Ancrene Wisse - as a guide to anchoresses and as a work of pastoral literature - allows connections to be made with other works within the history of vernacular spirituality. The most important of these works - that is, significant to modern scholarship and popular to their contemporary readership - are the writings of the 'Middle English Mystics'; these are late fourteenth-century spiritual writers, including Richard Rolle, Walter Hilton, Julian of Norwich and the author of Cloud of Unknowing.

These were writers who explored the contemplative life the possible approach of the individual to God through meditation and contemplation. Julian of Norwich's Showings, though widely studied now, were probably not widely circulated during her lifetime, ${ }^{1}$ and there seems to have been a deliberate, and successful, attempt to keep Cloud of Unknowing from being read by 'inexpert readers', 2 but both Richard Rolle and Walter Hilton had a wide readership; Rolle was particularly popular among his contemporaries, ${ }^{3}$ while Hilton's The Scale of Perfection was widely read in the fifteenth century. ${ }^{4}$ Margery Kempe recorded in her Book the books read to her by a priest, 'many a good boke of hy 
contemplacyon and other bokys, as the Bybyl wyth doctowrys therupon, Seynt Brydys boke, Hyltons boke, Boneventur, Stimulus Amoris, Incendium Amoris, and swech other'. ${ }^{5}$ I want here to explore Ancrene Wisse as a contemplative work, expressing a spirituality that was both affective and ascetic.

In the late twelfth century, Richard of St Victor, an acknowledged influence on the fourteenth-century English writers, ${ }^{6}$ defined contemplatio as:

the free, more penetrating gaze of a mind, suspended with wonder concerning manifestations of wisdom; or certainly as it was determined by a distinguished theologian of our time who defined it in these words: contemplation is a penetrating and free gaze of a soul extended everywhere in perceiving things. ${ }^{7}$

Richard is quoting from the first of Hugh of St Victor's sermons on Ecclesiastes, in which Hugh distinguishes contemplation from meditation. Meditation is always limited by the thing meditated upon and the capacity of the one meditating; contemplation is the very life-force of understanding, which is able to grasp and comprehend the whole completely and clearly: 'Contemplation is that acumen of intelligence which, keeping all things open to view, comprehends all with clear vision.' ${ }^{8}$ Hugh suggests there are two grades of contemplation, the lower contemplating creatures, the higher, the Creator: a lively extended metaphor of a fire describes this higher contemplation, which consumes everything and transforms everything into its own likeness; ${ }^{9}$ contemplation of God becomes union with God - which is commonly called the mystical experience. It is this union with God that is the goal both of contemplation, and of the whole contemplative life.

Fourteenth-century writers such as Walter Hilton used the term contemplatioun to mean both the contemplative life and union with God through contemplative prayer: 'The thridde partie of contemplatioun, whiche is perfite as it may be here, lieth bothe in cognicion and in affeccion: that is for to seie, in knowyng and in perfight lovynge of God. ${ }^{10}$ The first reference given in the Middle English Dictionary to the English word contemplacioun is from the Corpus Christi text of Ancrene Wisse, where 'contemplatiun' is defined (as though 
a neologism) as 'high thought' and used to describe the elevated and solitary life of the anchoress: she occupies her time with contemplation and holy prayers. ${ }^{11}$ In the late fourteenth-century anonymous Cloud of Unknowing, the higher part of the active life is identified with the lower part of the contemplative life, and includes meditation and prayer:

De lower party of actiue liif stondep in good \& honeste bodily werkes of mercy \& of charite. Pe hier party of contemplatiue liif \& pe lower party of contemplatiue liif lip in goodly goostly meditacions, $\&$ besy beholding vnto a mans own wrechidnes, wip sorow \& contricion, vnto pe Passion of Crist $\&$ of his seruantes wip pite \& compassion, \& vnto pe wonderful ziftes, kyndnes, \& werkes of God in alle his creatures, bodili \& goostly, wip pankyng $\&$ preising. ${ }^{12}$

Although not the same as contemplation, meditative exercises form an important part of affective spirituality and the contemplative life. Meditations on the joys of the Virgin Mary and on the Passion of Christ are prescribed for the anchoresses in Part One of Ancrene Wisse: they are told to spend their time in 'Reciting versicles from the Psalter, reading in English or in French, pious meditations'. ${ }^{13}$ In Walter Hilton's The Scale of Perfection, 'redyinge of Holi Writ and of hooli techynge, goosteli meditacion and besi praeris' are listed as the tools of the contemplative life, though it is recognized that the original reader - a female anchorite - 'mai not wel use' holy reading. ${ }^{14}$ This is similar to the 'conventional triad of lectio, meditatio, oratio associated with the contemplative life' ${ }^{15}$ at the end of the twelfth century, the Carthusian Prior Guy II likened the spiritual journey of the contemplative vocation to a ladder with four main stages: reading, meditation, prayer and contemplation. ${ }^{16}$

The meditations prescribed in Ancrene Wisse were very much concerned with God incarnate; Savage rightly claims that, 'The anchoritic goal of ecstatic union with Christ is in a specifically incarnational embrace', and draws a comparison with Julian of Norwich, who was reluctant to withdraw her gaze from the cross, even to look up to heaven, 'For I hadde lever hafe bene in that paine to domesdaye, than hafe comen to hevene otherewise than be him'. ${ }^{17}$ In Julian of Norwich's 
Showings, God descends to earth and is present in the visible form of Jesus on the cross; Watson writes of the Short Text ('A Vision'), 'The work disagrees with those who think that life must move beyond the carnal exercise of meditation of Christ's humanity to more abstract exercises, and insists that the deepest truths can be understood by continuing to focus on the humanity'. ${ }^{18}$ It is in her concentration on the suffering of Christ on the cross that Julian can be placed within 'the culture of affective spirituality that pervaded popular religious life during the late Middle Ages'; ${ }^{19}$ Julian's description of Christ emphasizes his physical torment, and that she saw him without intermediary:

And in this, sodenly I saw the red bloud trekile down from under the garlande, hote and freshely, plentously and lively, right as it was in the time that the garland of thornes was pressed on his blessed head. Right so, both God and man, the same that sufferd for me. I conceived truly and mightily that it was himselfe that shewed it me, without any meane. ${ }^{20}$

Elizabeth Robertson, in her exploration of Ancrene Wisse and the 'material immanence' that she argues the anchoresses experience in their reading of the book, also emphasizes the physicality of their meditations: 'Only two things matter in the world of the Ancrene Wisse, the immediate sensual apprehension of the world and its relationship to Christ's humanity and transcendence of that humanity. ${ }^{21}$ In Ancrene Wisse, the incarnate God is present as the image on the crucifix, and in the consecrated Host which is the very body and blood of Christ.

Elizabeth Alvilda Petroff suggests that meditative exercises, visualizing the lives of Mary and Christ, would lead to visionary experiences, especially in the closed, female community of a nunnery: such a community 'is exactly the environment in which religious impulses will surface in psychic phenomena and ecstatic states of consciousness'. ${ }^{2}$ There is no suggestion in Ancrene Wisse that the meditations the anchoresses engaged in could be used to induce visionary experiences; rather, all visions are the trickery of the devil: 'You should not regard any vision that you see, whether in a dream or a waking state, as anything but a delusion, because 
it is nothing but his trickery'. ${ }^{23}$ When the anchoresses are advised to meditate on the Passion of Christ, it is as a comparison with their own, lesser suffering, so that they may identify with Christ and endure their own hardship: their meditations were grounded in an ascetic life, in imitation of the suffering of Christ.

The anchoress may at times, as during the Eucharist, experience a state of ecstasy as an affective response to the presence of God. Christ, sacrificed for the redemption of humanity, is bodily present for the anchoress in the consecrated bread and wine, and she is encouraged to take advantage of this moment. Christ is also the lover of the anchoress, and the descent of God in the form of Christ the lover into the heart of the anchoress, where she embraces him, is one of the most significant moments in Ancrene Wisse. It is couched in terms of nuptial imagery:

After the kiss of peace in the Mass, when the priest is taking Communion, there forget all the world, there be quite out of the body, there in burning love embrace your lover, who has descended from heaven into the chamber of your breast, and hold him tightly until he was granted you everything that you ask. $^{24}$

The anchoresses heard Mass daily, and accompanied it with their own prayers and devotions, concentrating on their own sinfulness and the salvation of the world through the sacrifice of Christ. This is the most explicit expression in Ancrene Wisse of the quest for union with God, but it was also a moment that was available to all devout Christians. Other moments of contemplation are more closely related to the anchoritic life - a life that rejected the world and was dedicated to Christ, the only bridegroom of the anchoresses.

Rejecting the world and embracing a life of asceticism had long been considered a necessary preparation for contemplation; Cuthbert Butler points out that this was the case for Augustine and Gregory - both were important influences on Ancrene Wisse. Augustine acknowledged that there could be no contemplation without asceticism: 'no progress in prayer without mortification; no contemplation without self-denial and self-discipline seriously undertaken; 
no real mysticism without asceticism'. ${ }^{25}$ For Gregory also asceticism - the rejection of worldly things - was a necessary preparation for contemplation: 'acceptance of the sweetness of God also causes attachment to the world to grow weak'. ${ }^{26}$ The fourteenth-century vernacular writers recognized that the journey to God started in penitence, as in this short anonymous work, 'Mystical Prayer':

\begin{abstract}
When a solle begynyth to fele grace werke in hym, he wexyt then sory for hys synne, and rememberyth hys gret unkyndnes don agenst God an in what peryll his soll ys in. Anone he wepyth and waylyth his offence, and with gret sorow and lamentacyon cryth and callyth to God for mercy. Then thus contynewing, he gettyth hym to relygyon, or at-lest-wysse to confessyon, ther purgyng hymself clene from alle rust of syn by contricyon and penance-doyng. ${ }^{27}$
\end{abstract}

This short work traces the path from sin, through repentance and sorrow to consolation and desire for God, culminating in joy when 'God with lovely cownttynance takyth the solle and pottyth hym into the mydyst of hys hart'. ${ }^{28}$ Such a journey is normally understood within the context of the devoted, contemplative life, but Hilton suggested that it was also possible to pursue a 'mixed life': a life lived out in the world which had prayer and meditation at its heart. ${ }^{29}$ This movement of spirituality out from the enclosure of the monastery into the lives of devout lay people is reflected in the literature - the works of vernacular spirituality that collected Ancrene Wisse alongside The Scale of Perfection.

The 'good werkes of actif liyf' Hilton wrote of in his 'Epistle on the Mixed Life' could form part of a spiritual life - he describes them as fuel for the soul - and in Book Two of the Scale he 'sees contemplation as something which all rational souls created in the image of God should desire and dispose themselves to receive, whatever their state in life'. ${ }^{30}$ We have seen that parts of Ancrene Wisse were written with a wider audience in mind, and we shall see that the evidence of its later redactions suggests a lay readership for the whole. Nevertheless, the author understood the truly contemplative life as one removed from the world: the anchoresses had chosen the way of Mary, rather than that of Martha: 'You 
recluses have followed Mary's way ... Mary's part is silence and peace from all the noise of the world, so that nothing may prevent her from hearing God's voice.' 31 Mary, the sister of Martha was, understood as the model of the contemplative, as opposed to the active, life, and often conflated with Mary Magdalene. ${ }^{32}$ In Cloud of Unknowing, there is reference to the gulf between the sinner, Mary Magdalene, and God, and that the only way Mary could bridge this gulf is through longing for the love of God, rather than through dwelling on her own sinfulness. ${ }^{33}$ She is described as gazing at 'the supreme wisdom' of God and experienced a period of contemplation, but was still separated by the "cloud of unknowing' from God:

sche beheeld ... to pe souereynest wisdom of his Godheed lappid in pe derk wordes of his Manheed: peder beheeld sche wip al pe loue of hir hert. For fro pens list hir not remowe for noping pat sche saw ne herde spoken ne done aboute hir; bot sat ful stille in hir body, wip many a swete priue \& a lysty loue put upon pat hize cloude of vnknowyng bitwix hir $\&$ hir God. ${ }^{34}$

Mary Magdalene was also a model for the contemplative life in Hilton's Scale: dwelling alone in a cave for thirty years, each day she was 'born up with angelis into the eyr, and was feed bothe bodi and soule bi the presence of hem'. ${ }^{35}$ The adaptability of Ancrene Wisse is seen in the fourteenth-century version found in MS Pepys 2498, where it is argued that, although Mary chose the better part, it is better to take the way of Martha and stay in the world until called by God: 'And then they will have the grace to please him much better than if they had sought high degree through their own will'. To claim such grace for one self leaves one open to the deceptions of the devil. ${ }^{36}$ In the 'Epistle on the Mixed Life', Hilton suggests a wealthy layman divide his time between Martha and Mary. ${ }^{37}$

The author of Ancrene Wisse was well aware of the temptations and deceptions that faced those pursuing a life of contemplation, and presented a life that is penitential and ascetic. He wrote, not directly about contemplation, but about the devotions and penances that constituted the contemplative life. Geoffrey Shepherd suggests that '[the author of Ancrene Wisse] does not exalt the life of pure 
contemplation. It is a life of penitence he urges throughout.' 38 Ancrene Wisse certainly concentrates more on penance than on contemplation: Part Six of Ancrene Wisse begins, 'Everything that you have to bear, my dear sisters, is penance, and hard penance', ${ }^{39}$ but the distinction is a false one. The privations of the anchoritic life provided the conditions for contemplation, as Ann Warren suggests: 'The contemplation of God is fundamentally the purpose of the solitary life, the penitential aspects of such a life being the preparation for a journey toward a heightened consciousness'. ${ }^{40}$ Warren claims that texts from the later Middle Ages have a greater emphasis on mystical union than do high medieval texts, such as Ancrene Wisse, which mention the achievement of the mystical moment 'only in passing'. ${ }^{41}$ There is not, however, a clear distinction between early and late texts; ${ }^{42}$ rather, Ancrene Wisse is part of a tradition which exploited the language of affective spirituality to express a growing 'vernacular mysticism'. ${ }^{43}$ Contemplation is at the heart of the ascetic and penitential life described in Ancrene Wisse.

Richard of St Victor wrote of a progress through personal discipline to the goal of contemplation. ${ }^{44}$ 'The Mystical Ark', or 'De Gratia Contemplationis', Richard's mature work on the contemplative experience, lists six degrees or kinds of contemplation, the sixth one being 'above reason and seemingly beyond reason'. ${ }^{45}$ Richard understood contemplation as a looking towards or gazing upon God, through which God may be comprehended; it did not have to involve ecstasy. He suggested that the height of contemplation could be reached by hard work as well as by being rapt up by grace:

Among those who are led above themselves in their contemplations and are carried up to ecstasy of mind, some await and receive this even now only from the summons of grace. On the other hand, others can acquire this for themselves by great activity of soul, yet with the cooperation of grace. The former have this gift fortuitously, as it were; but the latter already possess it as though from virtue. ${ }^{46}$

Richard of St Victor argued that even if we can see 'beyond the veil' in a state of ecstatic contemplation, the memory itself cannot be fully recalled: 'And again: when we return to 
ourselves from that state of sublimity, we are completely unable to recall to our memory, with that truth and clarity we earlier observed, those things which earlier we saw above ourselves. ${ }^{47}$ Such an account of the mystical experience owes much to the classic account provided by Saint Augustine in his Confessions and elsewhere. ${ }^{48}$

Augustine combined an intellectual examination of the apprehension of God with a description of his personal experience of the sight of God. This experience is marked by a sense of 'the soul's longing for God: a longing that is a longing to return, to return to the One who made it', ${ }^{49}$ a longing which Augustine expressed in a passage of great poetic beauty:

You called me; you cried aloud to me; you broke my barrier of deafness. You shone upon me; your radiance enveloped me; you put my blindness to flight. You shed your fragrance about me; I drew breath and now I gasp for your sweet odour. I tasted you, and now I hunger and thirst for you. You touched me, and I am inflamed with love of your peace. ${ }^{50}$

Augustine's experience was personal and intimate, involving all the senses, but he specifically used the image of sight for knowledge of God; he wrote that 'sight is the principal sense by which knowledge is acquired'. ${ }^{51}$ Augustine does write of hearing the word of God and (in the familiar reference to Psalm 34) tasting how sweet he is; ${ }^{52}$ but perception was the paradigm of knowledge, and metaphors of illumination and vision were used to express intellectual and spiritual knowledge. ${ }^{53}$

The references to contemplation in Ancrene Wisse, even the most 'mystical' passage where the anchoress is told to embrace Christ in her heart during the Eucharist, are very different from Augustine's description of his own experience. There is no suggestion that the author of Ancrene Wisse is ever describing the personal experience of the contemplation of God; he writes, not in the first person but in the second, addressing the anchoress. Nor is the author concerned with a theological account of the nature of God; he does, however, use the language of sight. Part Two is concerned with how the outer senses should guard the heart; it provides a discussion of 
the role of contemplation, not in isolation, but within the ascetic life of anchoritic spirituality. In the passage beginning 'Zelatus sum Syon zelo magno', 'I was jealous of Zion with great jealousy', the close relationship between contemplation and the anchoritic life is described. ${ }^{54}$ Bridal imagery forms the background to this passage, and the anchoress is reminded that she is the spouse of a jealous God; ${ }^{55}$ her lover is also bashful and will only embrace his beloved in a secret place, but what follows is not a description of an erotic union with the divine so much as a moral exhortation.

The text quotes from the Song of Songs: 'Look at me if you want to see clearly with the eyes of your heart. Look inwards, where I am, and do not search for me outside your heart. ${ }^{56}$ To allow God to enter her heart, which is his chamber, the anchoress must be blind outwardly and seek the inner light: by this inner light she will attain spiritual sight and knowledge:

God will give you ... inward light to see and know him, and through that knowledge to love him above all things. Then you will see how all the world is nothing, how its comfort is false. Through that sight you will see all the devil's wiles ... You will see in yourself what still needs correcting of your own sins. You will look sometimes towards the pains of hell, so that you may feel terror of them, and flee from them all the more. You will see in spirit the joys of heaven, so that they may inflame your heart to hasten towards them. ${ }^{57}$

The imagery used here is that traditionally associated with contemplation: 'the desire for interior light and for vision of God through the eyes of the heart which is present in Augustine and Gregory and the nuptial imagery developed by St Bernard to describe the union of the soul with God in prayer' ${ }^{58}$ However, union with God is not described: the joys of heaven are promised as a reward, but there is also a reminder of the pains of hell.

That 'the heart is God's chamber - and thus that in contemplation he is found within, not outside, the soul' is, according to Savage and Watson, a commonplace, but an 'important commonplace'. ${ }^{59}$ In Bernard's Sermon 35 on the Song of Songs, for example, the contemplation of divine things is interior: 
The soul has been taught by the Lord and received the power to enter into itself, to long for the presence of God in its inmost depths, to seek his face continually - for God is a spirit (John $4,24)$, and those who seek him ought to walk by the promptings of the Spirit rather than of the Flesh (Galatians 5, 16; Romans 8, 12). ${ }^{60}$

This is from Bernard's sermon on Song of Songs 1: 7, 'Si te ignoras, egredere', 'If you do not know yourself, go forth': those who live in the flesh rather than in the spirit are sent out with the goats. The contemplation of divine things is possible only for those who have rejected the sensual world: 'It is a terrible, an awe-inspiring threat. As much as to say: know yourself unworthy of things heavenly, things of the spirit, divine things.' 61

This passage from the Song of Songs, and Bernard's exegesis, is referred to later in this part of Ancrene Wisse: "If you do not know yourself". . . that is, "If you do not know whose bride you are ... go out and depart ... and follow the herd of goats"'. ${ }^{62}$ The goats are the desires of the flesh which should be abjured for the sake of remaining faithful to God. This recalls the warning in the gospel of St Matthew that when the Son of Man returns in glory he will separate the sheep from the goats. The sheep, placed on his right hand, will inherit the kingdom, while the goats, on the left, will go away into everlasting punishment (Matthew 25: 31-46).

Hilton, who stresses the importance of knowing oneself as the starting position for contemplation, also uses this passage from the Song of Songs, with a similar interpretation of the kids as bodily desires:

And it is thus moche for to seie: Thou soule faire in kynde, maad to the likenesse of God, freel as woman in thi bodi for thi first synne, bicause that thou knowist not thisilf, that aungels foode schulde be thi delites withinne, therfore thou goost out bi thi bodili wittes and sekest thi mete and thi likynge as a beest of the flook, that is, as oon of the reproved; and therwith thou fedist thi thoughtes and thyn affecciouns, whiche aren unclene as kides. ${ }^{63}$

Looking within, knowing yourself and your true self through its spiritual relationship with God, rather than following your 
fleshly desires, is at the heart of the contemplation advocated in Ancrene Wisse. The anchoress is to be the mirror, 'schawere', of God, and show her face only to him. ${ }^{64}$ That the soul should be the mirror of God and that one can look within to see him reflected there is an ancient idea; Andrew Louth traces the image of the soul as a mirror reflecting God to Athanasius in the fourth century. ${ }^{65}$ It is the soul of a person which is made in the likeness of God and, through the operation of reason, most nearly approaches him, and so can be a mirror of him. The soul as a mirror of God is stated most clearly in Hilton's Scale of Perfection:

for thi soule is but a myroure, in the whiche thou schalt seen God goostli. And therfore thou schalt first fynden thi myrour and kepen it bright and clene from fleschli filthe and wordli vanyté, and holden it wel up from the erthe, that thou mai seen it, and oure Lord therinne also. ${ }^{66}$

The possibility of seeing God in the mirror of the soul is firmly associated with the need to keep the mirror clean, that is, by reforming the soul in the image of God. The image of a mirror is used again in Ancrene Wisse, when the anchoresses are assured that they will see the joys of heaven:

You will, as if in a mirror, see our Lady with her virgins, all the host of angels, all the assembly of saints, and above them him who makes them all rejoice, and is the crown of all of them. This sight, dear sisters, will comfort you more than any worldly sight. ${ }^{67}$

The sight of heaven the anchoresses can enjoy through contemplation while still on earth is obscured, as though in a mirror; ${ }^{68}$ but they are assured that they will enjoy the clear view of the face of God in the bliss of heaven 'much before the others' ${ }^{69}$ This is their reward for their suffering in this world: 'for a just God has decreed that each person's reward in the next world should correspond to the labour and the trouble that they patiently suffer in this world for his love' ${ }^{70}$

The clear sight the anchoresses will achieve in heaven, and of which contemplation can give a foretaste, is one of the two morning-gifts, marheouen, they are promised; as a recompense 
for being enclosed in this world, the anchoresses will be "both lighter and swifter in the next, and range at will in the wide pastures of heaven'. ${ }^{71}$ Morning-gifts were the gifts given by a husband to his bride on the morning after the wedding - after the consummation of the marriage. ${ }^{72}$ Their sight in heaven will also be an understanding of 'God's hidden secrets and his mysterious works' ${ }^{73}$ The inward, spiritual sight can be given by grace, but one must first blind oneself to the outer world. Such promises of future bliss fit in with the main purpose of Ancrene Wisse, which is to support and encourage the anchoresses in their choice of a penitential and ascetic life; this is the life of perfection to be pursued by the anchoresses, leading to ultimate union with God.

Bernard of Clairvaux understood contemplation as the goal of the discipline of the contemplative life; beginning with self-knowledge, the soul could ascend to knowledge of God. ${ }^{74}$ Bernard also wrote, in a letter to Prior Guy and other religious of the contemplative order of the Grande Chartreuse, of this ascent in terms of love. As we are flesh, the love of God has to begin with the love of ourselves; one can then move to love God for the sake of man and, as one comes to know God through meditation, reading and prayer, and to delight in him, 'tasting how sweet he is', one passes to the third stage, which is to love God for his own sake. Bernard doubts, though, whether it is possible to pass to the fourth stage in this life, when 'a man loves himself only for God's sake'. ${ }^{75}$ In 'Liber de Diligendo Deo', Bernard of Clairvaux describes the fourth stage of loving God as a total loss of self. This is not possible by human effort, but the soul is 'to be caught up to it' by the power of God. ${ }^{76}$ Bernard seems to question whether this is possible in this world, since souls, being 'too much bound to their bodies', cannot 'wholly remove themselves and transport themselves to God'. ${ }^{77}$ The word 'wholly', in toto, is important: it may be possible to have a vision of and experience a degree of union with God in this world, but it cannot be complete, as Bernard also suggested in a letter to Carthusian brothers, written twenty years earlier and appended to the 'Liber de Diligendo Deo'. Here again it is full attainment of the fourth stage that may not be possible: 
In this way, when he has tasted how sweet the Lord is (Ps. 33.9), he passes to the third stage, where he loves God, not now for himself, but for God's sake. Truly he remains for a long time in that state, and I do not know whether the fourth stage, where a man comes to love himself only for God's sake, is fully attained by anyone in this life. If anyone has experienced it, let him say so. To me it seems impossible. ${ }^{78}$

In Part Six of Ancrene Wisse an image of progression in the Christian life - from pilgrim, to dead, to crucified on the cross with Christ - is taken from Bernard's sixth Sermon for Lent. Bernard was addressing a monastic audience, and for him the three stages, gradūs, represented stages of the contemplative life. In Bernard's exposition of the third stage, when one is not only dead to the world but 'crucified - which is a shameful kind of death', ${ }^{79}$ there is a reference to the experience of the vision of heaven St Paul recounts in his second letter to the Corinthians (2 Cor. 12: 2): St Paul was snatched up to the third heaven and granted a vision that few can hope for. The three stages Bernard describes in his Sixth Sermon for Lent are, in fact, stages of renunciation: moving towards contemplation and its goal of union with God, the contemplative moves away from the things of the world.

Ancrene Wisse uses Bernard's progression of pilgrim, dead and crucified to represent, not stages of contemplation within the monastic life, but different forms of Christian life, the highest, represented by those crucified on the cross with Christ, being the life of the anchoress: 'And so, you see, true anchoresses are not just pilgrims, or even the dead, but belong to this third group; because all their joy is in being hanged painfully and shamefully with Jesus on his cross.' 80 Shepherd argues that omitting 'St Paul's flight to the third heaven' in Part Six shows the lack of concern in Ancrene Wisse with the 'experience of union with God'; 81 there is no mention of being caught up to heaven, yet union with God is precisely what Ancrene Wisse presents as the goal of the anchoritic life, even if it cannot be fully experienced in this world.

The idea of progress is important in the fourteenth-century conception of contemplation: the Cloud-author 'assumes that his disciple has passed through various stages of the spiritual life before acquiring the capacity to contemplate'. ${ }^{82}$ Barry 
Windeatt writes of the English mystical writers that their subject 'is nothing less than the way to God through love, and their aim is to give their reader direction, charting and signposting a schematic, progressive ascent'. ${ }^{83}$ One must be careful, however, not to confuse the idea of progress through the contemplative life - the different stages indicated by Bernard - with the idea of ascent to God in contemplation. In Ancrene Wisse there may be some progress within the anchoritic life as the anchoress is taught and trained by her heavenly husband, but there is no ascent to God; rather, Christ is invited down into the hearts of the anchoresses.

The anchoritic life described in Ancrene Wisse is an ascetic one: the unremitting practice of endurance, and a constant battle against temptation that will be won only after death. But this asceticism is a necessary part of the contemplative life and a preparation for contemplation; the anchoress needs to make herself open to the presence of God through discipline and devotion. Reference to the suffering of Christ is made in order to strengthen the resolution of the anchoresses and confirm that their suffering will be rewarded in heaven, not to grant them a vision on this earth. Later in Part Six, there is reference to the transformation of bodies at the Resurrection, ${ }^{84}$ and the anchoresses are told that, on the Day of Judgement, 'your flesh will shine brighter than the sun, if it is torn here with suffering and with pain'. ${ }^{85}$

In De Institutione Inclusarum, Aelred described two forms of knowledge of God:

Exult now, virgin, draw near and do not delay to claim for yourself some portion of this sweetness. If you are not capable of greater things, leave John to cheer himself with the wine of gladness in the knowledge of the Godhead while you run to feed on the milk which flows from Christ's humanity. ${ }^{86}$

These metaphors - drinking the wine of gladness, or the milk flowing from the breast of Christ's humanity - express two ways of knowing God, as the note to this passage points out: 'The Cistercian Fathers frequently contrast these two forms of the knowledge of God. One through the humanity of Christ and the other through some experience of God as he is in himself.' ${ }^{\prime} 7$ The milk flowing from Christ's humanity describes 
the affective spirituality of the anchoresses. Hilton also referred to the image of John laying his head on Jesus' breast as a model of contemplation - he 'was raveschid bi love into contemplacion of Goddis privetees'. ${ }^{88}$ Hilton used this description of the contemplation of John to suggest the difference between the active and contemplative lives: he was contrasted with Peter, 'which hadde the staat of actif lif'. This state - resting on the breast of Jesus - is the ideal of contemplation. Like Aelred's sister, the anchoresses should be content with knowledge of - and so union with - God through his descent in the humanity of Christ, rather than through ascent to him and direct knowledge of him.

Contemplation was traditionally associated with a specialized and elite form of religious life; but we see in Ancrene Wisse how the contemplative life could be available to those not trained in the rigours of monasticism. In this, it is looking forward to the late medieval vernacular writings of the English mystics, which are associated, not with monasticism, but with a religious movement that has more in common with the lay origins of high medieval anchoritism. These were works which were written for those who did not necessarily have the benefit of monastic teaching, either because they were lay-anchorites or because they were following a 'mixed life', but who wanted to find ways of experiencing contemplation and even religious ecstasy, and who expressed their desire for a personal experience of God in the language of vernacular spirituality. 


\section{2 \\ Reading Ancrene Wisse as vernacular spirituality}

The fact that Ancrene Wisse was written in the vernacular is important; in using and adapting Latin literature in a vernacular work intended for a lay or semi-regular audience in the first half of the thirteenth century, the author of Ancrene Wisse was at the forefront of the dissemination of pastoralia. The complex structure of Ancrene Wisse allowed practical advice, of the sort found in a summa confessorum, as well as directions about devotions, to be united with a spiritual discourse on the contemplation of God and the ascetic nature of the anchoritic life. In this, Ancrene Wisse anticipated the vernacular religious literature of the fourteenth and fifteenth centuries. This literature includes pastoral works giving direction to clergy, following the publication in 1281 of Archbishop Pecham's 'Ignorantia Sacerdotum' in response to the Fourth Lateran Council. This proclamation set out the 'minimum of theological knowledge necessary for the laity to know and the clergy to preach'; $;$ it also includes the writings of the 'Middle English Mystics'. We have already considered the pastoral elements of Ancrene Wisse; this chapter will explore Ancrene Wisse in a wider role as a work of a vernacular spirituality, taking into account its readership in the centuries following its composition.

Nicholas Watson places Ancrene Wisse within the history of the development of an English vernacular theology, arguing that the borrowing of material from Ancrene Wisse in such works as Nicholas Love's Mirror of the Blessed Life of Jesus Christ and The Chastising of God's Children points towards the 'laicization' of devotional works and 'a fourteenth-century world in which the laity, not the female solitary, slowly 
becomes the object of vernacular anxiety and attention'. ${ }^{2}$ Watson has modified the position he expressed in 'The methods and objectives of thirteenth-century anchoritic devotion' ${ }^{3}$ in which he maintained a distinct contrast between thirteenth-century anchoritic spirituality and late fourteenthcentury devotional and mystical writing; in his entry on the 'Middle English Mystics' for the Cambridge History of Medieval English Literature, he places both Ancrene Wisse and the fourteenth-century literature in the history of vernacular theology, while, in his essay in the Companion to Ancrene Wisse, he emphasizes the importance of Ancrene Wisse as a forerunner of, and influence on, later vernacular work. $^{4}$

Watson uses the term vernacular theology to cover this devotional literature, whether originally written in the vernacular, like Ancrene Wisse, or, like Edmund's Speculum and Love's Mirror, translated from Latin. ${ }^{5}$ I prefer the term vernacular spirituality, since the term theology can draw attention away from the personal and devotional nature of texts, such as Ancrene Wisse, which are concerned, not with the theory of theology, but with its practical application in devotional practices and daily life. Vernacular spirituality is a term that can cover both works of pastoral guidance and more personal expressions of religious experience. It is a literature concerned mostly with how to live a life of perfection, whether or not within the limits of a religious order, and which, in the later Middle Ages, found a new readership among the educated, pious laity.

The term spirituality, however, is problematic, and it must not be assumed that its meaning is identical with the Latin spiritualitas, or that its meaning has remained constant over the centuries. In the Middle Ages, spiritualitas was understood as the opposite of 'carnal' or 'material', but its meaning narrowed from the high Middle Ages as it came to be associated with specific religious practices. The Oxford Dictionary of the Christian Church suggests that 'a 'spiritual life' came to be regarded as more or less identical with interior religion and the explicitly devotional practices used to foster it'; ${ }^{6}$ Constable suggest that spirituality 'refers not just to piety and emotion but to the point where faith and action 
intersect'. ${ }^{7}$ Ancrene Wisse is concerned with the spiritual life in this sense; it is a life lived at the intersection between interior faith and the outward expression of that faith in devotional practices.

The incarnational spirituality expressed in Ancrene Wisse was also the driving force of the mysticism that flourished in the fourteenth century. The physicality of Julian of Norwich's descriptions of the suffering of Christ have been mentioned; Walter Hilton claimed that God may not be seen in his Godhead, but 'thou may thorugh devout biholdynge of His precious manhede fele His godenesse and the grace of His Godhede'. ${ }^{8}$ What the 'English mystics' were interested in was not necessarily an ecstatic or visionary experience. Richard Rolle claimed it was difficult to say what contemplation is, but continued, 'Soothly me thinketh that contemplacioun is a wunderful joye of Goddes love, conceyved in the soule with swetnesse of aungeles lovinge'. ${ }^{9}$ Hilton, however, was wary of the sort of experiences Rolle writes about: visions and revelations and other phenomena, such as sweet smells and a warm glow, 'aren not verili contemplacion; ne thei aren but symple and secundarie though thei be good, in regard of goostli vertues and in goostli knowynge and loovyng of God'. He also suggests that such phenomena as sweet sound and burning heat may be tokens of inner spiritual grace, but they are not themselves 'goostli feelynges'. ${ }^{10}$ We have seen that the author of Ancrene Wisse wrote about visions with the same caution.

It is with Hilton's Scale that comparisons with Ancrene Wisse can most easily - and profitably - be made. Like Ancrene Wisse, these fourteenth-century works were often written to a 'personally known recipient', while also acknowledging other readers: ${ }^{11}$ the first part of the Scale was written as guidance for an anchoress known to the author. The second part, written some years later, is an expanded discussion of the contemplative life to a more general audience - the friend at whose request it is written may be a 'literary fiction'. ${ }^{12}$ In the Preface of Ancrene Wisse a distinction is made between active and contemplative forms of religious life; the anchoresses are to follow the contemplative life and are told, 'keep yourselves pure and unspotted from the world 
more than other religious' ${ }^{13}$ Hilton makes a similar distinction: those in the contemplative life should not be concerned with the reproof of others, since that is the responsibility of those who are in the active life and have the cure of others, 'as prelatis and curates and swich othere'. ${ }^{14}$ Hilton does, however, suggest that it is part of the duty of the anchoress to provide counsel to those in need, even if this means breaking off from her prayer. ${ }^{15}$ In this, one of the few references to what may be considered the 'Outer Rule' of anchoritic life, the Scale differs noticeably from Ancrene Wisse; in many other respects, however, there are marked similarities.

In his introduction to a recent edition of this work, Thomas Bestul is at pains not to describe it as 'mystical', but refers to it as maintaining a secure place among 'the major religious treatises written in fourteenth-century England', and as a 'guide to the contemplative life'. ${ }^{16}$ Like Ancrene Wisse, it deals with the perfection of the individual soul as well as including some practical advice; Bestul notes that this practical advice 'is of the kind that enlivens a work such as the Ancrene Wisse'. ${ }^{17}$ The manuscript evidence suggests that, again like Ancrene Wisse, the appeal of the work extended beyond the anchorhold; the manuscript chosen by Bestul for his edition is London, Lambeth Palace MS 472, an anthology containing other works by Hilton and apparently made for a grocer of London in the early fifteenth century. ${ }^{18}$

Hilton did not promote the solitary life at the expense of other forms of religious vocation; in other works, he praised the active life and even, writing to a recluse, seems to question the usefulness of the contemplative life:

What do we do, you and I and our like, lazy and useless men, standing all the day idle. We do not labour in the vineyard of the lord, administering the holy rites of the Church, nor do we go from parish to parish, preaching the word of God . . . ${ }^{19}$

In the 'Epistle on the Mixed Life' he advises a wealthy layman with business and family responsibilities not to abandon 'occupacioun and bisynesse of the world', since those responsibilities bind him to the world: 'For it falleth not to 
thee, and yif thou do soo thou kepest not the ordre of charite.' Rather, he should try to do both: 'Thou schalt meedele the werkes of actif liyf with goostli werkes of lif contemplatif, and thanne doost thou weel.'20

Hilton emphasizes the 'purgative' aspect of the reclusive life; ${ }^{21}$ the main theme of the Scale is the need to reform the human soul to the likeness of God - the soul is made in the image of God but has been deformed by sin. In the first part, that addressed specifically to an anchoress, Hilton insists that full knowledge of God is not possible in this world, 'though thou were raveschid into the thridde hevene with Poule, yit haste thou not fulli founden Jhesu as $\mathrm{He}$ is in His joie'. ${ }^{22}$ The contemplative life is but the beginning of knowing him:

For that is the lif that is veri contemplatif, unto bigynne here in that felynge of love and goosteli knowynge of God bi openyng of the goostli iye, whiche shal nevere be loste ne bi taken awey, but the same schal be fulfilled othirwise in the blisse of hevene. ${ }^{23}$

Complete, perfect reform of the soul is possible only in the bliss of heaven, ${ }^{24}$ and it is in this perfect reformation that God is contemplated.

The contemplation of God is available to all Christians who love God, ${ }^{25}$ not only contemplatives, although the state of anchoritic living is a high one, meriting special reward in heaven:

And overe this I seie more, in comforte of thee and of alle othere havynge the staat of anker inclos, and also bi the grace of God in comfort of him alle that entren ony religioun approved bi Holi Chirche, that alle thoo that bi the merci of oure Lord schal be savyd, thei schal have special mede and a singuler worschipe in the blisse of hevene for here staat of lyvynge, bifore othere soulis that hadden not that staat in Holi Chirche, though thei be nevere so hooli. ${ }^{26}$

This reminds us of the reward promised to the anchoresses in Ancrene Wisse. The elements described by Hilton - spiritual meditation, awareness of one's own wretched state (involving 
an analysis of the seven sins), ${ }^{27}$ utter humility and consideration of Christ's Passion - are central to the spiritual life advocated in Ancrene Wisse. Hilton does not employ the kind of lengthy similitudes found in Ancrene Wisse, but he does use 'ensaumples', including that of the sinful soul being like a sick person in need of medicine. ${ }^{28}$ The same scriptural quotations are often found in the Scale: the heart must be guarded, 'Omni custodia serua cor tuum, quoniam ex ipso procedit uita'. ${ }^{29}$ The author of Ancrene Wisse suggests sin can enter the soul through the windows of the eyes; ${ }^{30}$ for Hilton all five senses are as windows. Hilton's interpretation of the passage from the Song of Songs (1: 7), 'Si ignoras te ...', 'If you do not know yourself', is also comparable to that in Part Two of Ancrene Wisse: your soul is made in the likeness of God and you must recognize this, and not follow your bodily senses and desires, like a kid which is unclean and follows the herd. ${ }^{31}$

There is also a similarity in tone between Hilton and the author of Ancrene Wisse, as noted by Helen Gardner:

The purpose of [Hilton's] writing is seen to be ... an attempt to put into simple language and adapt for the needs of individual souls the general teaching of the Church ... It reminds us of the Riwle [that is, Ancrene Wisse] in its moderation and sanity, in its gentleness, its wise and temperate asceticism. ${ }^{32}$

Gardner concludes that both Hilton's writing and Ancrene Wisse are characteristically English with their 'blend of tenderness and humour, the tolerance and modesty of spirit, the gentleness and intimacy'. ${ }^{33}$ Like the author of Ancrene Wisse, Hilton advises moderation: eat what food you need, but beware of greed. ${ }^{34}$ Helen Gardner suggests that Hilton 'almost certainly knew' Ancrene Wisse, ${ }^{35}$ and more recently Catherine Innes-Parker also claims that there is evidence that Hilton was 'influenced by Ancrene Wisse'. ${ }^{36}$

In The Scale of Perfection, as in Ancrene Wisse, it is recognized that children cannot digest the food of adults, that is, the knowledge of God. According to Hilton, there are two ways of knowing God, one in the imagination and the other in understanding. Knowing God in the imagination - through 
a sensual apprehension 'with manli affeccions and with bodili likenesse' - is 'likned to mylk bi the which thei aren tendirli norischid as children'. The knowledge of God in the understanding, through the illumination of the Holy Ghost, is the whole bread eaten at the father's table. ${ }^{37}$ A similar image, with reference to St Paul's first Epistle to the Corinthians, and his Epistle to the Hebrews, is found in Bernard of Clairvaux's first Sermon on the Song of Songs, where it is suggested the preacher gives milk to the people in the world, and saves a more nourishing diet for 'those who are spiritually enlightened'. This follows on from the sentence quoted earlier about different audiences 'quibus alia dicenda sunt, aut certe aliter'. ${ }^{38}$ The food for the soul still needs to be broken up, and things said in a different way for new readers.

Comparisons with works such as The Scale of Perfection establish the place of Ancrene Wisse in the history of vernacular spirituality. To fully understand and appreciate Ancrene Wisse as a work of vernacular spirituality, we need to take its readers - those for whom it was originally written and those for whom it was later adapted - into account. Our reading must incorporate their reading. 'The reader' is both the modern academic and the medieval readers - the original three anchoresses and others. We read over their shoulders the texts made for them to read. Elizabeth Robertson suggests a collaborative effort in the composition of Ancrene Wisse, ${ }^{39}$ and Anne Savage also suggests some female, communal agency in its authorship. ${ }^{40}$ The first version of Ancrene Wisse was written, and the revisions found in MS Corpus Christi made, with specific readers in mind - first the three beloved sisters, and then the larger number, 'twenty or more', of anchoresses but we should not allow our interest in these initial readers to blind us to the presence of other readers who were inscribed within the text. Robertson acknowledges several audiences, suggesting the reader is also 'cast as multiple' - as both an ideal and a real anchoress; ${ }^{41}$ in fact, the 'real' anchoresses are those whose behaviour needs less correction: they are themselves models of ideal behaviour, while other potential readers of the text may need more correction.

E. J. Dobson, Bella Millett and A. S. G. Edwards all give accounts of the manuscripts in which versions of Ancrene 
Wisse appear; ${ }^{42}$ and now all versions have been edited for the Early English Text Society, the preface of each edition provides useful information on palaeography and provenance. ${ }^{43}$ Not all the versions are complete or in the order of the original: the mid thirteenth-century manuscript Gonville and Caius College 234/120 contains a 'composite' of selections from the text in a 'non-sequential' or even 'haphazard' order, while the version in BL Royal 8 C.i is a reworking of Parts Two and Three. ${ }^{44}$ This raises the question of how one determines that a text is a version of Ancrene Wisse: how much shared material does there have to be with a text such as Corpus Christi or Cleopatra, which are considered to be close to the original?

Such questions have to be addressed by editors of medieval texts. ${ }^{45}$ Textual study is vital - and central - to medieval studies, where the texts are manuscripts and each individual redaction is not an exact copy but a new version - a new edition, even. It is textual study that allows us to learn much about reading, access to literature and the transmission of ideas; this is an area that is now attracting attention. In his introduction to a collection of essays on textual criticism, D. C. Greetham writes of an investigation of books that receive scholarly editing which suggested class, gender and race bias in the books chosen for such editing. He asks:

Was there perhaps something patriarchal, elitist, even racist, about the very construction of the traditional scholarly edition, with its approved text of accepted 'authorized' readings and its separate apparatus of 'rejected' readings (and thus literally 'inferior' - at the bottom of the page or the back of the book)? ${ }^{46}$

The issues raised by the editing of medieval texts - preserved in manuscript redactions, each of which will present variations - are different, but such questions of hierarchical status must bear some weight in the decisions made by editors. Arguably (if somewhat facetiously), the choice of Corpus Christi 402 as the preferred version of Ancrene Wisse disrupts patriarchal prejudices - though this disruption was surely perpetrated by the original author, who chose to write in the third language of the country, the language of gently 
born women. Latin texts may have had greater intellectual authority, and the French ones higher social status, ${ }^{47}$ but it is as an early English text that Ancrene Wisse is particularly valuable to scholars. It is also a version obviously directed towards women, although versions with male pronouns, adapted for male monastic audiences, do exist.

The early translation into French, however, gives an insight into the trilingual nature of literature in England. For example, a French Compileison made soon after the composition of Ancrene Wisse includes much of Ancrene Wisse, although in a different order. ${ }^{48}$ The compiler - who was not merely compiling, but through his translation and reordering writing anew - may have originally intended the work for 'cloistered religious', but the final work was one with wider application, ${ }^{49}$ serving 'both lay and religious folk as a religious manual. ${ }^{50}$ The Trinity manuscript of the Compileison was given to the library of Norwich priory around the turn of the fourteenth century; Watson and Wogan-Browne use the evidence of this manuscript, written in French in England, to question assumptions about social superiority and cultural bastardization of 'Anglo-Norman', while also highlighting the importance of this version of Ancrene Wisse in the history of vernacular spirituality: 'In the Compileison, Ancrene Wisse is also an East Anglian French text for use by men and women, lay and religious, in one of the busiest and most diverse urban contexts of the medieval English eastern coastlands. ${ }^{51}$

The various versions and translations of Ancrene Wisse show their adaptation for different readers, male and female, lay and religious. The Latin version found in BL Cotton Vitellius E.vii, now much damaged by fire, appeared in a list for Henry VII's library under the title 'Vita anachoritarum utriusque sexus' (A life of anchorites of both verse). Adaptations for male readers often involved only perfunctory changes in the gender of pronouns: the editor of the Titus manuscript has pointed out 'confusion' and 'carelessness' in the use of personal pronouns, ${ }^{52}$ and Millett has suggested that at some point the version preserved in this manuscript was adapted back for a female audience from an earlier form, since there are feminine pronouns in Titus that do not appear in the other manuscripts. 
Such adaptations seem to suggest that the teaching was thought of as relevant to both female and male readers. ${ }^{53}$

The active involvement of readers in the composition and compilation of texts is also getting attention. Felicity Riddy comments that 'we should not assume that women were merely passive recipients of books, or that they could not have taken the initiative in the process of translating from Latin into the vernacular'. ${ }^{54}$ This argument is made with reference to later, fourteenth-century works, works written by male clerics for women, and, where necessary, translated into the vernacular they could read; Riddy argues,

The assiduous pastoral activity in the two centuries after the fourth Lateran council in 1215 ... could hardly have taken place if the laity had not been avid to learn. In the relation between the male clerks and their women readers it must often have been difficult to tell who followed and who led. ${ }^{55}$

Her argument includes a consideration of the Vernon manuscript, in which an important version of Ancrene Wisse occurs, alongside the Middle English translation of $D e$ Institutione Inclusarum.

It is particularly in the fourteenth century that we see the growth of religious and devotional texts in the vernacular for an expanded, lay readership. Vincent Gillespie points out, within the context of this expansion and the apparently free movement of books 'between clerical and lay readers', that five of the surviving versions of Ancrene Wisse were made in the fourteenth century. ${ }^{56}$ Of particular interest are the two versions found in the Pepys and Vernon manuscripts, which raises the question: should the orthodox version of Ancrene Wisse found in the Vernon manuscript be preferred to the near contemporary and possibly heterodox version found in Pepys 2498?

Derek Pearsall suggests that the compilers of the Vernon manuscript, which also includes Part One of Hilton's Scale, and English translations of Aelred's De Institutione Inclusarum and Edmund of Abingdon's Speculum, may have seen the collection as 'yet another bulwark against the encroachment of that popular form of religion that had spread so vigorously among lay people and which was so threatening to the established church'. ${ }^{57}$ The original author of Ancrene 
Wisse was able to thank God that heresy was not prevalent, and so not something for his beloved sisters to worry about; it is interesting to note that the versions in the Vernon and Pepys manuscripts, both written at the time of the growth in Lollardy, repeat the claim that heresy does not reign in England. ${ }^{58}$ For Walter Hilton, writing towards the end of the fourteenth century, it was clearly a matter of concern. ${ }^{59}$ The Vernon manuscript is a huge anthology, weighing nearly fifty pounds and containing material adapted for a lay as well as a religious audience. Its sheer size, and the cost of its manufacture, would suggest it was compiled for an institution, though it is not clear whether this was a convent of nuns or some less regular community of religious women. ${ }^{60}$ The manuscript contains texts designed both for religious and devout lay readers, but they all present an orthodox view of spirituality.

Christina von Nolcken has revisited the question of whether the version of Ancrene Wisse that is found in MS Pepys 2498, where it is referred to as 'Dis good book Recluse', is a 'Lollard interpolation'. ${ }^{61}$ Pepys 2498 is also a large folio, measuring about 34 by 24 centimetres and containing 232 leaves; it is in a London dialect and believed to come from the Waltham Abbey area of Essex, not far from London. ${ }^{62}$ Included in the Pepys manuscript is the Middle English translation of Robert de Gretham's Anglo-Norman verse Miroir, a collection of sermons for Sundays and saints' days throughout the year. Originally intended for the private devotions of Lady Elena of Quency, it was always anticipated that they would have 'a broader audience than one fairly well-off woman', and the author addresses his readers in the masculine plural. The title of the book as 'Mirror' is significant; it is intended to function 'as a looking-glass for the soul'. ${ }^{63}$ As von Nolcken has shown, The Recluse is not straightforwardly Wycliffite; there are inconsistencies that are open to different interpretations. Von Nolcken suggests two (at least) revisions, an early one without Lollard sympathies, but a later one by someone "whose career and preoccupations were very much what we might expect of an early Lollard'. ${ }^{64}$ This second redactor might have been a cleric, who was probably in the patronage of 'the upper laity'; ${ }^{65}$ he was certainly adapting Ancrene Wisse for a secular 
audience. In the late fourteenth century, teaching on the reclusive life reaches beyond the anchorhold: the Pepys version of Ancrene Wisse substitutes for an exclusive, anchoritic spirituality one which could be attained by people in the world, though the devout themselves strove for a new form of exclusivity, separated from the wicked. ${ }^{66}$

The adaptations of Ancrene Wisse and their readership opens up a new area of textual scholarship, and is one which has recently been explored by Catherine Innes-Parker and Nicholas Watson. ${ }^{67}$ Versions of Ancrene Wisse - in particular the Latin translations - were used by male and female religious, and even the early Cleopatra manuscript passed into the hands of Augustinian canonesses before the end of the thirteenth century. It has been argued that Ancrene Wisse may be a source of the Dublin Rule; the parallels do not seem significant enough to suggest that Ancrene Wisse was an important source, but the similarities do place it within the sphere of regular religious guidance. ${ }^{68}$

Of particular interest for the role of Ancrene Wisse in the history of vernacular spirituality is its influence on later vernacular religious texts designed for lay readership. Borrowings from Ancrene Wisse in fourteenth-century vernacular religious texts have been acknowledged since the 1920s, when Hope Emily Allen first pointed out that The Chastising of God's Children, 'a well-known Middle English theological treatise addressed to a nun', took its title and theme from a passage in Ancrene Wisse. ${ }^{69}$ This 'image of God as a mother who plays with her wayward child' and the 'complex tangle' of its textual history is explored - and some attempt made to sort out the tangle - by Innes-Parker. ${ }^{70}$ The image of the wind blowing harder on a hilltop to represent those in an exalted life being exposed to greater temptation, which is found at the beginning of Part Four of Ancrene Wisse ${ }^{71}$ is also used without acknowledgement in Chastising and Poore Caitiff. ${ }^{72}$ The Chastising was possibly written for a Barking nun and was popular, especially in religious houses, throughout the fifteenth century. There is evidence of Carthusian ownership, and copies were owned by Brigittine nuns of Syon. ${ }^{73}$ The author was cautious about writing in English, given the political climate of the time - he was 
probably writing soon before 1407, when Archbishop Arundel's Constitutions of Oxford were issued, prohibiting the use of English Bibles; nevertheless, he would not condemn the reading of material in English 'where pei mowen stire zou more to deuocion and the pe loue of god' ${ }^{74} \mathrm{He}$ himself obviously felt it important to provide this devotional material in English as an example to those following a religious life.

There is a complicated history of borrowings found in anthologies and miscellanies, some of which have borrowed via a mediating text - Allen identified a Latin text which translates part of Ancrene Wisse in a fifteenth-century Bodleian Laud manuscript, but whose composition presumably originally dates from before Poore Caitiff, which 'seems to give it [the Latin text] in English' and which 'probably belongs to the second half of the fourteenth century'. ${ }^{75}$ The circulation of texts of Chastising and Poore Caitiff shows them to have had a broad readership among religious and lay readers, male and female, ${ }^{76}$ and Innes-Parker draws some interesting conclusions about the existence of reading circles:

It is apparent that the ideas and images drawn from Ancrene Wisse circulated freely ... These images and ideas would thus have become very familiar to the reading audiences of the fourteenth and fifteenth centuries. Their widespread influence becomes even more apparent when one considers the exchange of texts and the oral transmission indicated by reading circles. It is clear that the influence of Ancrene Wisse on future generations is much broader even than that indicated by evidence of direct literary dependence. ${ }^{77}$

There is an apparent reference to Ancrene Wisse in Nicholas Love's Mirror of the Blessed Life of Jesus Christ which, 'to judge by the number of surviving manuscripts and early prints', was 'one of the most well-read books in late-medieval England'. ${ }^{78}$ Love's Mirror, dating from the early fifteenth century, is the 'only complete' medieval translation into English of the pseudo-Bonaventuran Meditationes Vitae Christi ${ }^{79}$ it was to be used as a guide to meditation on the life of Christ. In the section on the Annunciation, the Ave Maria (in English) is used as the basis for meditations on the Five 
Joys of Mary. The Five Joys of Mary were an important element in late medieval lay piety, but it is in Ancrene Wisse that we find 'the earliest known example of the devotion to the Five Joys set out in an elaborate form, ${ }^{80}$ and there seems to be evidence that Nicholas Love knew this formulation of the Joys. Love's wording does not bear comparison with that in Ancrene Wisse, and he gives the 'Hail Mary' in English, rather than the Latin Ave Maria found in Ancrene Wisse, but one branch of the manuscript family of the Mirror adds, at the end of the meditations on the Joys: 'Thus penkep me may be hadde contemplacioun more conueniently aftir pe ordre of pe fyue ioyes of oure lady seynt marye in pe forseide gretynge Aue Maria \&c. pan was byfore wryten to pe Ankeresse. ${ }^{81}$

Watson claims that here Love is cautious about suggesting the reader should identify with Mary: there is an anxiety about elite religious practices being used by the laity. ${ }^{82}$ Although the Meditationes he was translating was a Franciscan text, Love himself was a Carthusian, and one therefore dedicated to an exclusive and contemplative religious life. His Mirror was also studiously orthodox, and was licensed for dissemination by Archbishop Arundel, thereby playing 'a major role in Archbishop Arundel's campaign against the Wycliffite heresy'. ${ }^{83}$ Ancrene Wisse itself was orthodox, but it has left its footprints in works both orthodox and heterodox, and interest in it did not end with the Reformation.

The transmission of passages from Ancrene Wisse through Latin into vernacular anthologies suggests something of the adaptability of the work. Anthologies commissioned for lay readers were often 'common profit' books; that is, they were intended for circulation amongst a circle of friends and, at the death of the original commissioner, they would be left to someone, to continue the circulation for the spiritual profit or benefit of others. ${ }^{84}$ Ancrene Wisse itself had, in a sense, become a work of common profit; with no sense of authorial copyright, compilers of anthologies could use passages from it suitable for their own purposes and the benefit of their own readers.

The version of Ancrene Wisse to which the title most properly applies, that found in MS Corpus Christi College, 
Cambridge 402, resides in the Parker Library of Corpus Christi College. This is the repository of the books collected by Archbishop Matthew Parker during the reign of Elizabeth I; Parker was commissioned to collect and preserve 'auncient recordes or monumentes written' that, since the dissolution of the monasteries, had passed into private hands. ${ }^{85}$ Parker used the books collected for his own study of the English Church; he was trying to prove that there had been a 'golden age of the English Church' to which the reformed Anglican Church was heir, and he 'selected books to prove the point'. ${ }^{86}$ Ancrene Wisse may not have been one of the most important books in Parker's collection, but its presence in the library should remind us of the place that Ancrene Wisse occupies in the English tradition of vernacular pastoral and spiritual literature.

\section{Notes to Part III}

\section{The rhetoric of Ancrene Wisse}

1 'Nv mine leoue sustren, pis boc Ich todeale on eahte 'destinctiuns', pet ze cleopieð dalen', AW Corpus Christi, fo. 4a 19-20.

2 James Murphy, 'Rhetoric', in Mantello and Rigg (eds), Medieval Latin, pp. 629-638 (p. 629).

3 Dobson, Origins, p. 84.

4 Introduction to Les Statuts de Prémontré, p. vi.

5 Acts 4 32, quoted at $A W$ Corpus Christi fo. 69a 11-12, and cf. 'Consuetudines fratrum predicatorum', in De oudste Constituties van de Dominicanen: voorgeschiedenis, tekst, bronnen, ontstaan en ontwikkeling (1215-1237) met uitgave van de tekst, Bibliothèque de la revue d'histoire ecclésiastique, Fasc. 42 (Leuven: Leuvense Universitaire Uitgaven, 1965), p. 311, and Statuts de Prémontré, ed. Lefèvre and Grauwen, p. 1.

6 'Consuetudines fratrum predicatorum', p. 312.

7 'Limpeð to alle men aliche', $A W$ Corpus Christi, fo. $93^{\text {a }} 4$.

8 Outlines showing the pattern of construction, based on division and subdivision, have been drawn up for Part One by Roger Dahood, 'Design in Part 1 of Ancrene Riwle', and for Part Seven by Dennis Rygiel, 'Structure and style in Part Seven of Ancrene Wisse', Neuphilologische Mitteilungen, 81 (1980), 47-56 (48-9). Catherine Innes-Parker gives an outline of the structure 
of a section of Part Seven in 'The Lady and the King: Ancrene Wisse's parable of the royal wooing re-examined', English Studies, 75 (1994), 509-22 (513-14).

9 Dahood, 'Design in Part 1', pp. 1, 2, 5.

10 Roger Dahood, 'The use of coloured initials and other division markers in early versions of Ancrene Riwle', in Edward Donald Kennedy, Ronald Waldron and Joesph S. Wittig (eds), Medieval English Studies Presented to George Kane (Woodbridge: Brewer, 1988), pp. 79-97.

11 AW Corpus Christi, fo. $4^{\mathrm{b}}$ 9-15.

12 'Omni custodia serua cor tuum, quia ex ipso uita procedit', 'Guard your heart with every precaution, because life issues from it', ibid., fo. $12^{\text {b }} 1-2$.

13 'I pis destinctiun aren chapitres fiue, as fif stuchen efter [be] fif wittes', 'In this distinction there are five chapters, that is, five sections corresponding to the five senses', ibid., fo. $4^{\text {a }} 26-7$.

14 Alexandra Barratt, 'The Five Wits and their structural significance in Part II of Ancrene Wisse', Medium Aevum, 56 (1987), 12-24 (14).

15 'Hire feire neb, hire hwite swire, hire lichte echnen', $A W$ Cleopatra fo. $24^{\mathrm{r}}$ (two folios of Corpus Christi have been lost at this point).

16 AW Corpus Christi, fo. 21 b 5 -fo. 23a 12.

17 Ibid., fo. $23^{\text {a }} 14-22$.

18 'Of eare is al pis leaste to ancre bihoue', ibid., fo. $23^{\text {a }} 25$.

19 'Spellunge and smechunge beoð i muð baðe, as sihðe is i pe ehe; ah we schulen leten smechunge apet we speoken of ower mete, ant speoken nu of spellunge, ant prefter of herunge - of ba imeane sumchearre, as ha gað togederes', ibid., fo. $15^{\text {b }} 14-18$.

20 'Hiderto is iseid of ower silence ... Nu we schulen sumhwet speoken of ower herunge', ibid., fo. 20 b $15-21$.

21 'Of sihðe, of speche, of hercnunge is iseid sunderlepes of euchan o rawe. Cume we nu eft azein ant speoken of alle imeane', ibid., fo. $23^{\text {a }} 28-$ fo. $23^{\text {b }} 2$.

22 Ibid.fo. $23^{\text {b }} 3$-fo. $27^{\text {b }} 7$.

23 'Dis beoð nu pe preo wittes pet Ich habbe ispeken of; speoke we nu scheortliche of pe twa opre', ibid., fo. $27^{\text {b }} 7-9$.

24 Ibid., fo. $31^{\text {b }} 14-18$.

25 Ibid., fo. 32 $6-10$.

26 'Pe pridde dale is of anes cunnes fuheles pe Dauið i pe Sawter eueneð him seolf to as he were ancre, ant hu pe cunde of pe ilke fuheles beoð ancren iliche', ibid., fo. $4^{\mathrm{b}} 1-3$.

27 One, taking verse 6, 'Similis factus sum pellicano', as its theme, was directed to 'claustrales', while another, with the theme 
'Factus sum sicut nycticorax', was directed to 'eremitas'; the sermons, to be preached either on the first Sunday 'in passione Domini' or on the Sunday 'resurrectionis Domini' are to be found in a collection of anonymous sermons at Troyes, J. B. Schneyer, Repertorium der Lateinischen Sermones des Mittelalters für die Zeit von 1150-1350, 9 vols. (Munster, 1969), vol. 9, p. 637. The verses are also used in the sermons of Aelred of Rievaulx, Sermones de Oneribus, in PL vol. 195, col. 481, and Absalon of Springiersbach, Sermones, in PL vol. 211, col. 38. AW Corpus Christi, fo. 35a 5-6; Matt. 8: 20 and Luke 9.58. Savage and Watson, Anchoritic Spirituality, pp. 359-60. Bataillon, 'Similitudines et exempla', p. 195. $A W$ Corpus Christi, fo. 44a $27-$ fo. $45^{\text {b }} 25$.

Corpus Christi College Cambridge, MS 402, fo. 45 a I am grateful for permission to examine this manuscript in the Parker Library.

33 For a discussion of some of this imagery, and in particular the use of figures of Old Testament women, see Cate Gunn, 'Beyond the tomb: Ancrene Wisse and lay piety', in McAvoy and HughesEdwards (eds), Anchorites, Wombs and Tombs, pp. 161-71 (pp. 164-5).

34 Leclercq, Love of Learning, p. 74. $A W$ Corpus Christi, fo. $46^{\mathrm{b}} 26-$ fo. $47^{\mathrm{a}} 5$. Newhauser, Treatise on Vices and Virtues, p. 64. 'Hu alle pe seouene deadliche sunnen muhen beon afleiet purh treowe bileaue', $A W$ Corpus Christi, fo. 67a 19-21. Bloomfield, Seven Deadly Sins, p. 151.

For Chaucer's indebtedness to Peraldus, see Introduction, Summa Virtutum de Remediis Anime, ed. Siegfried Wenzel, The Chaucer Library (Athens: University of Georgia Press, 1984); Dan Michel's Ayenbite of Inwyt is also a translation of the Somme le Roi, see Introduction, The Book of Vices and Virtues, ed. W. Nelson Francis, EETS o.s. 217 (London: Oxford University Press, 1942).

40 'Understondeð penne on alre earst, leoue sustren, pet twa cunne temptatiuns, twa cunne fondunges beoð, uttre ant inre, ant ba beoð feoleualde', $A W$ Corpus Christi, fo. 48 a 21-3.

41 '... fleschlich, as of leccherie, of glutunie, of slawðe; gastelich, as of prude, of onde, ant of wreaððe, alswa of õiscunge. Dus beoð pe inre fonduges be seouen heaued-sunnen, ant hare fule cundles.' ibid., fo. $51^{\text {b }} 6-9$.

42 Bloomfield, Seven Deadly Sins, p. 149.

43 AW Corpus Christi, between fo. 59 13 and fo. $78^{\mathrm{a}} 27$.

44 'De seueðe forbisne is pis, zef ze riht telleð', ibid., fo. 68 8 b-9; 'the reading is confirmed by the majority of the MSS running', but it 
is not clear whether 'the two missing exempla were never included, or were accidently omitted from the text at an early stage', Millett, notes to forthcoming EETS edition.

45 AW Corpus Christi, fo. 62 ${ }^{\mathrm{b}}$ 19-21.

46 'For se pe hul is herre, se pe wind is mare pron. Se pe hul is herre of hali lif ant of heh, se pe feonde puffes, pe windes of foundunges, beoð strengre pron ant mare', ibid., fo. 47b 24-7.

47 Ibid., fo. 47 $21-2$ and fo. $58^{\mathrm{b}} 16$.

48 '3ef Iesu Crist, ower spus, deð alswa bi ow, mine leoue sustren, ne punche ow neauer wunder', ibid., fo. 59a 18-19.

49 Ibid., fo. 93 $2-6$.

50 Bella Millett, 'Ancrene Wisse and the conditions of confession', English Studies, 80 (1999), 193-215 (194, 204).

51 'Our own conscience (that is, our sense of right and wrong)', AW Corpus Christi, fo. $83^{\mathrm{a}} 17$; this is the first recorded use of the word in English; and ibid., fo.86 5-6.

52 'Schrift schal beo wreiful, bitter mid sorhe, ihal, naket, ofte imaket, hihful, eadmod, scheomeful, dredful ant hopeful, wis, soð, ant willes, ahne ant studeuest, bipoht biuore longe. Her beoð nu as pah hit weren sixtene stuchen pe beoð ifeiet to schrift, ant we of euchan sum word schulen sunderliche seggen.' ibid., fo. 82 $6-11$.

53 See MS Corpus Christi College, Cambridge, 402, fos 82-92.

54 AW Corpus Christi, fo. 86 ${ }^{\mathrm{b}}$ 5-6.

55 Millett, 'Conditions of confession', p. 109.

56 'Bigin earst ed prude ant sech alle pe bohes prof as ha beoð pruppe iwritene, hwuch falle to pe', $A W$ Corpus Christi, fo. 91 ${ }^{\text {a }}$ 21-23.

57 'Ich am an ancre; a nunne; a wif iweddet; a meiden; a wummon ..., ibid., fo. $86^{\mathrm{b}} 12-13$.

58 'Euch efter pet he is segge his totagges, mon as limpeð to him, wummon pet hire rineð', ibid., fo. 87 $18-19$.

59 'Efter schrift falled to speoken of penitence, pet is deadbote; ant swa we habbed inzong ut of pis fifte dale into pe seste', ibid., 402 fo. $94^{\text {a }} 10-12$.

60 'Al is penitence, ant strong penitence, pet ze eauer dreheð, mine leoue sustren', ibid., fo. 94 $13-15$.

61 MS Corpus Christi College, Cambridge, 402, fo. 94ª.

62 'Leoue mon ant wummon, Godd puncheð god of ure god. Vre god is zef we doð pet tet we ahen', AW Corpus Christi, fo. $99^{\mathrm{b}}$ $1-3$.

63 Notably by Geoffrey Shepherd in his edition of Ancrene Wisse Pts 6 and 7.

64 There is a quotation from the Declamations from St Bernard's Sermons, usually ascribed to Geoffrey of Auxerre, at AW Corpus 
Christi, fo. 96 6, see Ancrene Wisse Pts. 6 and 7, ed. Shepherd, p. 34, and another at fo. $97^{\mathrm{a}} 13-14$; a reference to Bernard's Sermo 4, 'In Uigilia Natiuitatis Domini', is at fo. $96^{\mathrm{b}} 13$.

65 At AW Corpus Christi, fo. 96 ${ }^{\text {b }}$ 8-9; Adam of Dryburgh started out as a Premonstratensian canon but became a Carthusian in 1189 . Ibid., fo. 99 $13-27$.

67 Ibid., fo. $101^{\text {a }} 5$-f. $101^{\text {b }} 4$.

68 'Schir heorte, hwi me ah ant hwi me schal Iesu Crist luuien, ant hwet binimed us is luue ant let us him to luuien', ibid., fo. $4^{\mathrm{b}} 6-8$; Rygiel, 'Structure and style', p. 48.

69 'Earst, as a mon pe woheð', and 'Eft pe pridde reisun', $A W$ Corpus Christi, fo. $105^{\mathrm{a}} 11$ and fo. $106^{\mathrm{a}} 22$.

70 'Fowr heaued-luuen', ibid., fo. $106^{\mathrm{b}} 2$.

71 'Luue pe makeð schir heorte', ibid., fo. $103^{\mathrm{b}} 28$.

72 Rygiel, 'Structure and style', p. 56.

73 AW Corpus Christi, fo. $1^{\text {a }} 25-6$; the Latin passage in which this term occurs is not present in every version of $A W$ and may have originated as a marginal note, see Millett notes to forthcoming EETS edition.

74 AW Corpus Christi, fo. 20 a 6 ; this word, found in the Corpus Christi manuscript, is not present in all manuscripts; Millett believes it may have originated as a marginal annotation.

75 'Det his flesch wes cwic ouer alle flesches, lo, hwuc an essample', AW Corpus Christi, fo. $30^{\mathrm{b}} 22-3$.

76 See Jennifer Potts, Lorna Stevenson and Jocelyn Wogan-Browne (eds), Concordance to Ancrene Wisse MS Corpus Christi College Cambridge 402, (Cambridge: D. S. Brewer, 1993), p. 200.

77 Joseph Albert Mosher, The Exemplum in the Early Religious and Didactic Literature of England (New York: Columbia University Press, 1911), pp. 87-8.

78 AW Corpus Christi, fo. $85^{\mathrm{b}}$ 19-25; the latter could be called an exemplum although it is introduced as an analogy, 'He is ase men in a schip....

79 Forbisne or the plural forbisnes occurs fifteen times in the redaction of Ancrene Wisse found in Corpus Christi 402, see Concordance, pp. 233-4.

80 AW Corpus Christi, fo. $13^{\text {a }} 26$.

81 Ibid., fo. $17^{\mathrm{a}} 17$.

82 Ibid., fo. $19^{\text {b }} 6 \&$ fo. $31^{\text {a }} 16$.

83 'Durh hire forbisne ant purh hire hali beoden', ibid., fo. $38^{\mathrm{b}} 20$.

84 Ibid., fo. $42^{\text {a }} 6$, fo. $43^{\text {b }} 20$, fo. $44^{\text {a }} 7$, fo. $44^{\text {a }} 23$, fo. $44^{\text {a }} 25$.

85 Ibid., fo. $59^{\text {a }} 2$, fo. $68^{\text {a }} 5$, fo. $68^{\text {b }} 8$.

86 Ibid., fo. $105^{\text {a }} 17-18$.

87 For example, by Innes-Parker, in 'The Lady and the King'. 
88 'Alswa ure Lauerd, pet is pe sawle spus, pet sið al pet ha deð pah hehe sitte, he is ful wel ipaiet pet ha murneð efter him, ant wule hihin toward hire mucheles pe swiðere wið zeoue of his grace, oðer fecchen hire allunge to him, to gloire ant to blisse purhwuniende', $A W$ Corpus Christi, fo. 99 $3-13$.

89 Ibid., fo. 34 $16-17$.

90 Ibid., fo. $77^{\mathrm{b}} 27-$ fo. $78^{\mathrm{a}} 1$.

91 'A mon pe were idemet, for a luðer morðre, to beo forbearnd al cwic oðer scheomeliche ahonget, hu walde his herte stonden? Me, pu unseli sunful, pa pu purh deadlich sunne murðredest Godes spuse (pet is, pi sawle), pa pu were idemet forte beon ahonget o bearninde wearitreo i pe eche lei of helle', ibid., fo. 84 $16-22$.

92 'And nis he a cang cniht pe secheð reste i pe feht ant eise i pe place? Milicia est vita hominis super terram; al pis lif is a fecht, as Iob witneð', ibid., fo. $97^{\mathrm{a}}$ 6-8.

93 Ancrene Wisse Pts 6 and 7, ed. Shepherd p. xlviii.

94 AW Corpus Christi, fo. 98 $10-21$; and see Dennis Rygiel, 'A holistic approach to the style of Ancrene Wisse', Chancer Review, 16 (1982), 270-81.

95 AW Corpus Christi, fo. 98 $20-21$.

96 Price [Wogan-Browne], 'Inner and outer', p. 197.

97 Ibid., p. 199.

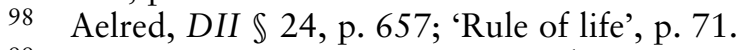

99 Price [Wogan-Browne], 'Inner and outer', p. 197; Aelred does offer the narrative of men he has known as examples of behaviour to avoid, see DII, $\mathbb{S} 18$ and 22; 'Rule of life', pp. 66-7, 69-70.

100 'Scheome ant pine', $A W$ Corpus Christi, fo. 96 $6-7$; also 'wa ant scheome' at fo. 96 23.

101 'Each word is like a hook', Leclercq, Love of Learning, pp. 73-4.

102 AW Corpus Christi, fo. 96 22 -fo. $96^{\mathrm{b}} 3$.

103 Ancrene Wisse Pts. 6 and 7, ed. Shepherd p. 35.

104 AW Corpus Christi, fo. 96 $6^{\text {b }}$ 5-7.

105 Ibid., fo. $101^{\text {a }} 2$-fo. $101^{\text {b }}$ 4. This passage uses English terms, deadbote and fondunge, rather than Latinate alternatives, but also uses a French word, ennu.

${ }^{106}$ N. Bériou and D. L. d'Avray, 'The image of the ideal husband in thirteenth-century France', in, N. Bériou, D. L. d'Avray et al. Modern Questions about Medieval Sermons: Essays on Marriage, Death, History and Sanctity (Spoleto: Centro Italiano di Studi Sull'Alto Medioevo, 1994), pp. 31-69.

107 'Nam Ich pinge feherest? Nam Ich kinge richest? Nam Ich hest icunnet? Nam Ich weolie wisest? Nam Ich monne hendest? Nam Ich pinge freoest?', $A W$ Corpus Christi, fo. 107b 7-10. 
108 Bériou and d'Avray, 'The image of the ideal husband', p. 51; Millett traced the development of such 'conditions of eligibility' and their use in Ancrene Wisse in a paper given at the International Medieval Congress, University of Leeds, 15 July 2003, 'The conditions of eligibility in the Ancrene Wisse Group'.

109 Bériou, 'La prédication', p. 187. This is one of a number of occasions where a phrase is recorded in French rather than Latin, suggesting an association with popular French literature, for example, the angel Gabriel is a 'cortois mesager', Ranulphe d'Hombières, Sermon 24, in Bériou, 'La prédication', p. 211.

110 AW Corpus Christi, fo. $105^{\mathrm{b}} 28-$ fo. $106^{\mathrm{a}} 1$.

111 'Forte penchen per-bi o Iesu Cristes cnihtschipe pet he dude o rode', ibid., fo. $106^{\text {a }} 25-6$.

\section{Ancrene Wisse: asceticism and contemplation}

1 Sister Benedicta points out that no contemporary manuscripts of either the Short or the Long Texts of Julian's Showings exist; the earliest copies of the complete Long Text date from the mid seventeenth century, and although the oldest copy of the Short Text is found in a fifteenth-century manuscript of devotional works, it was 'unknown until the beginning of this [i.e. the twentieth] century', Sister Benedicta [Ward], 'Julian the solitary', in K. Leech and Sr. Benedicta (eds), Julian Reconsidered, (SLG Press, 1988), pp. 11-31 (pp. 11-12).

2 Vincent Gillespie, 'Vernacular books of religion', in Jeremy Griffiths and Derek Pearsall (eds), Book Production and Publishing in Britain, 1375-1475 (Cambridge: Cambridge University Press, 1989), pp. 317-44 (p. 322).

3 David Knowles, The English Mystical Tradition (London: Burns and Oates, 1961), p. 48.

4 George Wood Tuma, The Fourteenth Century Mystics: A Comparative Analysis, 2 vols (Salzburg: Institut für Englische Sprache und Literatur, 1977), I, p. 34.

5 The Book of Margery Kempe, ed. Barry Windeatt (Harlow: Pearson Education, 2000), p. 280.

6 G. A. Zinn, Introduction to Richard of St Victor, The Twelve Patriarchs; The Mystical Ark; Book Three of the Trinity, trans. Grover A. Zinn, Classics of Western Spirituality (London: SPCK, 1979), p. 5.

7 'Libera mentis perspecacia in sapientiae spectacula cum admiratione suspensa, vel certe sicut praecipuo illi nostri 
temporis theologo placuit, qui eam in haec verba definivit. Contemplatio est perspicax et liber animi contuitus in res perspiciendas usquequaque diffusus.' Richard of St Victor, 'De Gratia Contemplationis', in PL 196, col. 67. Trans. as 'The Mystical Ark', in The Twelve Patriarchs, p. 157.

8 'Contemplatio est vivacitas illa intelligentiae quae cuncta in palam habens, manifesta visione comprehendit', Hugh of St Victor, In Salomonis Ecclesiasten Homiliae xix; Homilia Prima, PL 175, col. 117A, trans. as 'The Grades of Knowledge', in Ray C. Petry (ed.), Late Medieval Mysticism The Library of Christian Classics (Philadelphia: Westminster Press, 1957), p. 90.

9 Hugh of St Victor, In Salomonis, 117C-D; trans. in Petry (ed.), Late Medieval Mysticism, p. 91.

10 Hilton, Scale, I.8, pp. 37-8.

11 AW Corpus Christi, fo. 39a 14-15.

12 Cloud of Unknowing and The Book of Privy Counselling, ed. from manuscript by Phyllis Hodgson, EETS, OS 218 (London: Oxford University Press, 1944; repr. 1958), fo. 33a, pp. 31-2.

13 'Verseilunge of Sawter, redunge of Englisc oðer of Frensch, halie meditatiuns', AW Corpus Christi, fo. $11^{\text {a }} 22-3$.

14 Hilton, Scale, I.15, p. 45.

15 Notes to ibid., p. 45, and see Leclercq, Love of Learning, p. 72.

16 Danile Le Blévec, 'Carthusians', in André Vauchez et al. (eds), Encyclopedia of the Middle Ages, vol. I, trans. Adrian Walford (Cambridge: James Clarke, 2000), p. 246.

17 Savage, 'Solitary heroine', pp. 82-3; Julian, Section 10 of 'A Vision Showed to a Devout Woman', Writings, p. 85.

18 Watson, 'Middle English Mystics', in CHMEL, p. 558.

19 Denise Nowakowski Baker, Julian of Norwich's Showings: From Vision to Book (Princeton, NJ: Princeton University Press, 1994), p. 15.

20 Julian, Ch. 4, 'Revelation', Writings, p. 135.

21 Elizabeth Robertson, “This living hand': thirteenth-century female literacy, materialist immanence, and the reader of Ancrene Wisse', Speculum, 78 (2003), 1-36, (33).

22 Elizabeth Alvilda Petroff, Medieval Women's Visionary Literature (Oxford: Oxford University Press, 1986), p. 6.

23 ' $\mathrm{Na}$ sihðe pet ze seoð, ne i swefne ne waken, ne telle ze bute dweole, for nis bute his gile', $A W$ Corpus Christi, fo. 60 ${ }^{\text {b }} 24-6$.

24 'Efter pe measse cos, hwen pe preost sacreð - per forzeoteð al pe world, per beoð al ut of bodi, per i sperclinde luue bicluppeð ower leofmon, pe into ower breostes bur is iliht of heouene, any haldeð him heteueste apet he habbe izettet ow al pet ze eauer easkið.' ibid., fo. $8^{\mathrm{b}} 18-23$. 
25 Cuthbert Butler, Western Mysticism ([1922]; London: Arrow Books, pbk edn. 1960), p. 85.

26 'Agnitionem suitatis Dei', Gregory the Great, Homiliae in Hiezechihelem, Book 2, Hom. 2, in Corpus Christianorum Series Latina, vol. 142, p. 233; Butler translates this as 'the perception of the sweetness of God', Western Mysticism, p. 126, but agnitio can also mean recognition or acceptance.

27 'Mystical Prayer', apparently the work of a reader of the Cloudauthor, ed. from MS Douce 262 by Barry Windeatt, English Mystics of the Middle Ages (Cambridge: Cambridge University Press, 1994), p. 106.

28 Ibid., p. 107.

29 Walter Hilton, 'Epistle on the Mixed Life', ed. Windeatt, English Mystics, pp. 108-30.

30 Windeatt, (ed.) English Mystics, p. 156.

$313 \mathrm{e}$ ancren beod inumen ow to Marie dale ... Marie dale is stilnesse ant reste of alle worldes noise, bet na ping ne lette hire to heren Godes steuene.' AW Corpus Christi, fo. 112 $3-9$.

32 Giles Constable, Three Studies in Medieval Religious and Social Thought (Cambridge: Cambridge University Press, 1995; pbk edn, 1998), p. 6.

33 Cloud of Unknowing, ed. Hodgson, fo. 41 ${ }^{\mathrm{b}}, 15-18$, p. 46.

34 Ibid., fo. 42a, $6-16$.

35 Hilton, Scale, I.11, p. 42.

36 'And pan hij schullen haue grace forto queme hym wel better pan pat hij zeden to heize degre by her owen wille', The English Text of the Ancrene Riwle, ed. from Magdalene College. Cambridge MS Pepys 2498, ed. A. Zettersten, EETS, 274 (London: Oxford University Press, 1976), hereafter AW Pepys, p. 28. changing role of asceticism in the anchoritic ideal', Mystics' Quarterly, 28 (2002), 6-25.

43 Wolfgang Riehle, The Middle English Mystics trans. Bernard Standing (London: Routledge and Kegan Paul, 1981), p. 4.

44 Zinn, Introduction to Richard of St Victor, The Twelve Patriarchs, p. 7.

45 'Supra rationem, et videtur esse praeter rationem', Richard of St Victor, 'De Gratia Contemplationis', PL 196, col. 70; trans. in The Twelve Patriarchs, p. 161. 
46 'Eorum autem qui in suis contemplationibus supra semetipsos ducuntur et usque ad mentis excessum rapiuntur, alii hoc exspectant et accipiunt usque adhuc ex sola vocante gratia, alii vero et hoc possunt sibi comparant (cum gratiae tamen cooperatione) ex magna animi industria. Et illi quidem hoc donum quasi fortuitum habent, isti vero jam velut ex virtute possident.' Richard of St Victor, 'De Gratia Contemplationis', PL 196, col. 166; trans. in The Twelve Patriarchs, p. 305.

47 'Et item cum ab illo sublimitatis statu ad nosmetipsos redimus, illa quae prius super nosmetipsos vidimus in ea veritate vel claritate qua prius perspeximus ad nostram memoriam revocare omnino non possumus.' Richard of St Victor, 'De Gratia Contemplationis', IV.23, PL 196, col. 167; trans. In The Twelve Patriarchs, p. 306.

48 E.g. Augustine, Confessions, VII.17, ed. James O'Donnell, 3 vols. (Oxford: Clarendon Press, 1992), vol. I, p. 134; Confessions, trans. Pine-Coffin, p. 151, and cf. Butler, Western Mysticism, p. 80.

49 Andrew Louth, The Origins of the Christian Mystical Tradition from Plato to Denys (Oxford: Clarendon Press, 1981), p. 134.

50 'Vocasti et clamasti et rupisti surditatem mean; coruscasti, splenduisti et fugasti caecitatem mean; fragrasti, et duxi spiritum et anhelo tibi; gustavi et esurio et sitio, tetigisti me, et exarsi in pacem tuam', Augustine, Confessions, X.27, ed. O'Donnell, I, p. 134; trans. Pine-Coffin, p. 232.

51 'Quae quoniam in appetitu noscendi est, oculi aute, sunt ad noscendum in sensibus principes, concupiscentia oculorum eloquio divino appellata est', Augustine, Confessions, X.35, ed. O'Donnell, I, p. 140; trans. Pine-Coffin, p. 241.

52 O'Donnell notes that in Augustine's Enerrationes in Psalmos this 'tasting' is taken in a eucharistic sense, Confessions, III, p. 198.

53 Carolly Erickson, The Medieval Vision: Essays in History and Perception (New York: Oxford University Press, 1976), pp. 42-3.

$54 A W$ Corpus Christi fo. $23^{\mathrm{b}}$ 3, quoting Zechariah 8: 2.

55 'Vnderstond, ancre, hwas spuse pu art, ant hu he is gelus of alle pine lates. Ego sum deus zelotes', AW Corpus Christi, fo. $23^{\mathrm{b}}$ 4-5.

56 'Bihald me zef pu wult habbe briht sihðe wið pine heorte ehnen. Bihald inward, per Ich am, ant ne sech pu me nawt wiðute pin heorte', ibid., fo. 23 ${ }^{\text {b }} 17-19$.

57 'Godd wule ... zouen ow liht wiðinnen him to seon ant cnawen, ant purh pe cnawlechunge ouer alle ping him luuien. Denne schule $3^{e}$ iseon hu al pe world is nawt, hu hire froure is fals. Durh pet 
sihðe ze schule seon alle pe deofles wiheles .... 3e schulen iseon in ow seolf hwet beo zet to beten of ower ahne sunnen. 3e schulen bihalde sumcheare toward te pinen of helle, pet ow uggi wið ham ant fleo pe swiðere ham frommard. 3e schulen gasteliche iseon pe blissen of heouene, pe ontenden ower heorte to hihin ham toward.' Ibid., fo. 24a 13-23. seipsam, et in intimis suis Dei praesentiam suspirare, et quaerere faciem eius semper, - spiritus est enim Deus, et qui requirunt eum oportet eos in spiriut ambulare, et non in carne.' Bernard, Sermones in Cantica, 35, Opera, vol. 1, p. 249; trans. Walsh, On the Song of Songs, 2, Works, vol. 3, p. 165.

61 'Terribilis proinde et nimis formidolosa comminatio: Egredere et pasce haedos tuos. Quod est: Indignam te noveris illa tua familiari et suavi rerum contemplatione coelestium, intelligibilium divinarum', Bernard, Sermones in Cantica, 35, Opera, vol. 1, p. 249; trans. Walsh, On the Song of Songs, 2, Works, vol. 3, p. 166.

62 "'3ef pu ne cnawest te seolf" . . . pet is, "3ef pu nast hwas spuse pu art . . . went ut ant ga . . . ant folhe heorde of geat"', $A W$ Corpus Christi, fo. 26a 28 -fo. 26b 5.

63 Hilton, Scale, I.79, p. 121.

64 AW Corpus Christi, fo. 23 ${ }^{\text {b }} 14-15$; Bella Millett suggests lookout as a translation for 'schawere' in "'Syon", pet is "schawere", which would accord with the translation of speculum as 'lookout' in Hubert's Sermon 15 in Bériou, 'La prédication', p. 204; other translators favour mirror, see Savage and Watson, Anchoritic Spirituality, p. 82; Ancrene Wisse: Guide for Anchoresses, trans. Hugh White (London: Penguin, 1993), p. 47; The Ancrene Riwle (The Corpus MS: Ancrene Wisse), trans. M. B. Salu ([1955] University of Exeter Press, 1990), p. 40.

65 Louth, Christian Mystical Tradition, p. 79, and see Cate Gunn, 'Speculum feminarum: mirror images of medieval women' (unpub. MA dissertation, University of Essex, 1991), p. 11.

66 Hilton, Scale, II.30, p. 206.

67 ' $3 e$ schulen as I schawere iseon ure leafdi wið hire meidnes, al pe englene weoret, al pe halhene hird, ant him ouer ham alle pe blisseð ham alle, ant is hare alre crune. Dis sihðe, leoue sustren, schal frourin ow mare pen mahte ei worltlich sihðe.' AW Corpus Christi, fo. 24a $23-8$.

68 'Quasi per speculum in enigmate', quoted from 1 Cor. 13: 12; $A W$ Corpus Christi, fo. 24v 9-10; the idea that in this life one can 
only see God 'as in a glass, darkly' is a common one, e.g. Anselm in 'De Custodia Interioris Hominis', a work which 'had an extensive circulation throughout the Middle Ages', St Anselm, 'De Custodia Interioris Hominis', in R. W. Southern and F. S. Schmitt (eds), Memorials of St. Anselm, Auctores Britannici Medii Aevi, 1 (London: Oxford University Press, for the British Academy, 1969), pp. 354-60 (p. 354). 'Vidi deum, sed “per speculum et in enigmate" is on p. 358.

69 'Muche biuore pe opre', $A W$ Corpus Christi, fo. 24 2 12-13.

70 'For pe rihtwise Godd hit haueð swa idemet pet euchanes mede per ondswerie azein pe swinc ant azeines pe ennu pet ha her for his luue eadmodliche polieð', ibid., fo. $24^{\mathrm{b}}$ 13-16.

71 Ibid., fo. 24b 25-7.

72 Four morning-gifts are mentioned in Part One, ibid., fo. $7^{\mathrm{b}} 28$ : 'radiance/clarity', 'lightness', 'swiftness' and 'freedom from suffering'.

73 'Godes dearne runes ant his derue domes', ibid., fo. 25a 5-6.

74 Southern points out that this 'was not simply the doctrine of one man but the starting point of a whole generation of spiritual writers', R. W. Southern, The Making of the Middle Ages (London: Hutchinson, 1953), p. 219.

75 Bernard of Clairvaux, 'Epistola XI Ad Cartusienses et Guigoni Priori', in Opera, vol. 7 (1974), pp. 58-9; trans. in The Letters of Bernard of Clairvaux, ed. Bruno Scott James (London: Burns and Oates, 1953), pp. 46-7.

76 'Speret se anima quartum apprehendere amoris gradum, vel potius in ipso apprehendi: quippe quod Dei potentiae est dare cui vult, non humanae industriae assequi', Bernard of Clairvaus, 'De Diligendo Deo', X.29 in Opera, vol. 3 (1963), p. 144; Bernard of Clairvaux, 'On Loving God', in Selected Works, trans. G. R. Evans, Classics of Western Spirituality (New York: Paulist Press, 1987), p. 196.

77 'Non possunt ex toto animae seipsas exponere, et transire in Deum, nimirum ligatae corporibus etiam tunc', ibid., XI.30, p.145; trans. Selected Works, p. 197.

78 'Et sic gustato quam suavis est Dominus, transit ad tertium graduum, ut diligat Deum, non iam propter se, sed propter ipsum. Sane in hoc gradu diu statur, et nescio se a quoquam hominum quartus in hac vita perfecte apprehenditur, ut se scilicet homo diligat tantum propter Deum. Asserant hoc si qui experti sunt: mihi, fateor, impossibile videtur'. Ibid., XV.39, p. 153; trans. Selected Works, p. 204.

79 'Crucifixus, quod est ignominiosum genus mortis', Bernard of Clairvaux, 'In Quadragesima Sermo Sextus', in Opera, vol. 4; trans. Geoffrey Shepherd as Appendix to Ancrene Wisse Pts 6 
and 7, pp. 71-2; following its enumeration in Patrologia Latina, 183, Shepherd titles it 'St. Bernard's Seventh Sermon in Lent'; in the Opera of St Bernard, vol. 4, it appears as Sermo 6.

80 'Dus, lo, rihte ancres ne beoð nawt ane pilegrimes, ne zet nawt ane deade, ah beoð of peos pridde; for al hare blisse is forte beon ahonget sariliche ant scheomeliche wið Iesu on his rode', $A W$ Corpus Christi, fo. 95 $22-6$; with reference to Bernard of Clairvaux, 'In Quadragesima Sermo Sextus'.

81 Ancrene Wisse Parts 6 and 7, ed. Shepherd p. lvii.

82 Watson, 'Methods and objectives', p. 135.

83 Windeatt, English Mystics, p. 1.

84 AW Corpus Christi, fo. 97b 4.

85 'Ure flesch schal blikien schenre pen pe sunne, zef hit is totoren her wið wontreaðe ant wið weane', ibid., fo. 98 a 17-18.

86 'Iam nunc exulta, uirgo, accede proprius, et aliquam tibi huius dulcedinis portionem uendicare non differas. Si ad potiora non potes, dimitte Ioanni pectus, ubi uinum laetitiae in diuinitatis cognitione inebriet, tu currens ad ubera humanitatis, lac exprime quo nutriaris.' Aelred, $D I I, \mathbb{S} 31$, p. 668; trans. 'Rule of life', p. 87. The reference to 'Ioanni pectus' is to the image, mentioned earlier in the text, of John resting his head on Christ's breast.

87 Aelred, 'Rule of life', p. 87, n. 54.

88 Hilton, Scale, I.17, p. 49.

\section{Reading Ancrene Wisse as vernacular spirituality}

1 Nicholas Watson, 'Middle English Mystics', in CHMEL, pp. 539-65 (p. 548).

2 Nicholas Watson, 'Ancrene Wisse, religious reform and the late Middle Ages', in Companion, pp. 197-226 (p. 203).

3 Marion Glasscoe (ed.), The Medieval Mystical Tradition in England, Exeter Symposium IV (Woodbridge: Brewer, 1987), pp. 132-46.

4 Watson, 'Middle English Mystics' and 'Ancrene Wisse, religious reform and the late Middle Ages'. Watson defines vernacular theology at length in an article on Arundel's Constitutions; it is a term he uses as a 'catch-all' that will draw attention to the 'intellectual content' of religious texts in the vernacular which 'are often treated with condescension', Nicholas Watson, 'Censorship and cultural change in late-medieval England: vernacular theology, the Oxford translation debate, and Arundel's Constitutions of 1409', Speculum, 70 (1995), 822-64, (823, n. 4). 
5 For the argument that the Speculum Religiosorum is the original of Edmund's work and was subsequently translated into AngloNorman, see Edmund of Abingdon, Speculum Religiosorum and Speculum Ecclesie, ed. Helen P. Forshaw, Auctores Britannici Medii Aevi (London: Oxford University Press, for the British Academy, 1973), and Alan Wilshere, 'The Latin primacy of St Edmund's 'Mirror of Holy Church", Modern Language Review, 71 (1976), 500-12.

6 Oxford Dictionary of the Christian Church, pp. 1532-3; for further discussion of the use of the term spiritualitas in the Middle Ages, see André Vauchez, La Spiritualité du Moyen Âge Occidental VIIIe-XIIe siècles, Collection S.U.P. (Paris: Presses Universitaires de France, 1975), p. 5, trans. as The Spirituality of the Medieval West from the Eighth to the Twelfth Century by Colette Friedlander, Cistercian Studies No. 145 (Kalamazoo: Cistercian Publications, 1993); and Michel Dupuy, 'Spiritualité', in Dictionnaire de spiritualité ascétique et mystique, doctrine et histoire, fondé par M. Viller et al., continué par A. Derville et al., vol. 14 (Paris: Beauchesne, 1990), cols 1142-73.

7 Constable, Reformation, pp. 14-15.

8 Hilton, Scale, I.25, p. 58.

9 Richard Rolle, 'The Mendynge of Lyfe', in Windeatt (ed.), English Mystics, pp. 18-19.

10 Hilton, Scale, I.10, p. 40.

11 Windeatt, (ed.), English Mystics, pp. 4-5.

12 Gillespie, 'Vernacular books of religion', p. 322; Helen Gardner makes a similar point, 'Walter Hilton and the mystical tradition in England', Essays and Studies, 22 (1936), 103-127 (114).

13 'Witeð ow from pe worlt ouer oper religiuse cleane ant unwemmet', $A W$ Corpus Christi, fo. $3^{\text {a }}$ 26-7.

14 Hilton, Scale, I.17, p. 49, II.30, p. 209.

15 Ibid., I.83, p. 124.

16 Bestul, p. 1.

17 Ibid., p. 4.

18 Ibid., Introductin to Hilton, Scale, p. 8.

19 '. . quid ergo facimus. tu et ego nostrique similes himoniesque pigri et inutiles, tota die stantes ociosi. Non laboramus in vinea domini sacra ecclesiastica ministrando nec discurrimus perparochias uerbem dei predidcando' quoted from MS Royal 6 E.III, fo. 742 , and trans. by Gardner, 'Walter Hilton', p. 109.

20 Walter Hilton, 'Epistle on the Mixed Life' in English Mystics, p. 112.

21 Gardner, 'Walter Hilton', p. 110.

22 Hilton, Scale, I.46, p. 84. 
23 Ibid., I.45, p. 82.

24 Ibid., II.4, p. 141.

25 Ibid., II.10, p. 150.

26 Ibid., I.61, p. 100.

27 The sins are discussed in both Parts One and Two. In Part Two, Hilton uses images of animals to describe the effects the deadly sins have on people, e.g. Scale II,14, p. 161; in Ancrene Wisse it is the sins themselves and their offspring that are described as animals.

28 Hilton, Scale, I.74, p. 118, and II.17, p. 167.

29 Ibid., I.87, p. 128; this is the theme of Part 2 of Ancrene Wisse.

30 AW Cleopatra, fo. $25^{\mathrm{v}} 22$-fo. $26^{\mathrm{r}} 1$, pp. 51-2 (two folios of MS Corpus Christi are missing at this point), quoting St Bernard; the passage bears comparison with Jeremiah 9: 21 (quoted by Hilton), see note, Savage and Watson, Anchoritic Spirituality, p. 350.

31 Hilton, Scale, I.79, pp. 120-1.

32 Gardner, 'Walter Hilton', p. 120.

33 Ibid., p. 126.

34 Hilton, Scale, I. 76, p. 118.

35 Gardner, 'Walter Hilton', p.120.

36 Innes-Parker, 'The legacy of Ancrene Wisse', p. 147.

37 Hilton, Scale, II.31, p. 212. Gardner notes that this is derived from Augustine's In Epistolam Joannis, 'Walter Hilton', p. 121.

38 S. Bernardi Opera, vol. I, p. 3; trans. Walsh, On the Song of Songs, p. 1.

39 Elizabeth Robertson, 'Savouring "Scientia": the medieval anchoress reads Ancrene Wisse', in Companion, pp. 113-44; Robertson takes some of the ideas she explores here - especially the construction of the self through the intellectual and affective activity of reading - further in 'This living hand'.

40 Anne Savage, 'The communal authorship of Ancrene Wisse', in Companion, pp. 45-55.

41 Robertson, "“This living hand”, pp. 26-7.

42 Dobson provides a stemma codicum of manuscripts and versions of AW, Origins, p. 287; Millett, Annotated Bibliography, pp. 49-59, and A. S. G. Edwards, 'Early English manuscripts' and early readers of Ancrene Wisse in Companion pp. 103-12.

43 The last of these editions is The English Text of the Ancrene Riwle: The 'Vernon' Text, ed. from Oxford, Bodleian Library MS Eng. poet. a. 1, ed. Arne Zettersten and Bernhard Diensberg, introduction by H. L. Spencer, EETS 310 (Oxford: Oxford University Press, 2000); it was published too late for inclusion in Millett's Annotated Bibliography, where details of the other 
editions can be found. Bella Millett's forthcoming edition of Ancrene Wisse for the EETS is based on the Corpus Christi manuscript, but will provide alternative readings from other manuscripts and a full textual introduction.

44 Millett, Annotated Bibliography, pp. 55, 50, and A.S.G. Edwards, 'The early English manuscripts and early readers of Ancrene Wisse', in Companion, pp. 103-12, (p. 108).

45 E.g. Bella Millett, see her introduction to Ancrene Wisse (EETS, forthcoming).

46 D. C. Greetham, 'Introduction: out of the text and into the margins', in Margins of the Text, pp. 1-5 (p. 1).

47 Jocelyn Wogan-Browne and Nicholas Watson question the assumption that French texts written in England are of high social status, 'The French of England: the Compileison, Ancrene Wisse, and the idea of Anglo-Norman', Journal of Romance Studies 4 (2004), 35-59.

48 The French Text of the Ancrene Riwle edited from Trinity College Cambridge MS R. 14.7 with variants from Bibliothèque Nationale MS. fo. Fr. 6276 and MS. Bodley 90, ed. W. H. Trethewey, EETS 240 (London: Oxford University Press, 1958 (for 1954)), hereafter $A W$ Trinity; see Watson and WoganBrowne, 'French of England', Appendix, 56-9, for the order of the text in Compileison.

49 Watson and Wogan-Browne, 'French of England', 48.

50 AW Trinity, p. xi.

51 Watson and Wogan-Browne, 'French of England', 50.

52 Frances Mack, Introduction to The English Text of the Ancrene Riwle, edited from Cotton MS Titus D xviii, EETS 252 (London: Oxford University Press, 1963 (for 1962)), pp. xiv-xv.

53 Gunn, 'Lay piety', p. 165.

54 Felicity Riddy, "Women talking about the things of God": a late medieval sub-culture', in Women and Literature in Britain, pp. 104-127 (p. 107).

55 Ibid., p. 107.

56 Gillespie, 'Vernacular books of religion', pp. 319, 321.

57 Derek Pearsall, Introduction, in Derek Pearsall (ed.), Studies in the Vernon Manuscript (Cambridge: Brewer, 1990), pp. ix-xi (p. x).

58 'Heresie godd haue ponc ne rixleð nawt in englelond', $A W$ Corpus Christi, fo. 21 $12-13$; see Vernon, p. 31/7, Pepys, p. 33/26-7, though the change in word order in Pepys opens it to variable interpretation: 'Attry speche is heresye foul. pwertouer J lesynges. bakbitynges. and Losengerye. Alle pise ben wicked heresyes. Dis ne regnep nouzth in Engelonde.' 
59 Among other references to heretics, Hilton insists that they should be shunned, no matter how good they may seem, since they are rebels to God and the Holy Church, Scale, I.67, p. 106.

60 Spencer, Introduction to $A W$ Vernon, p. xiv; Pearsall, Introduction to Studies, p. x; A. I. Doyle also suggests that the collection was made for nuns 'or other devout women (anchoresses, vowesses or ladies of similar piety and spiritual counsel)', Introduction to The Vernon Manuscript: A Facsimile of Bodleian Library, Oxford, MS Eng. Poet. a. I (Cambridge: Brewer, 1987), p. 14. Both Spencer and Doyle suggest possible Cistercian associations.

61 'Dis good book Recluse' occurs at the end of the text, $A W$ Pepys, p. 184; Christina von Nolcken refers to it as 'The Recluse', see 'The Recluse and its readers', pp. 175-96; Eric [Edmund] Colledge suggested it was a Lollard revision, 'The Recluse: A Lollard interpolated version of the Ancrene Riwle', Review of English Studies, 15 (1939), 1-15, 129-45.

62 Zettersten, Introduction to $A W$ Pepys, pp. ix, xviii.

63 Kathleen Marie Blumreich, Introduction to The Middle English 'Mirror': An Edition Based on Bodleian Library, MS Holkham misc. 40, Arizona Center for Medieval and Renaissance Studies (Turnhout: Brepols, 2002), pp. xiii-xv.

64 Based on a suggestion by Anne Hudson in The Premature Reformation, von Nolcken, 'The Recluse', pp. 181, 182.

65 Von Nolcken, 'The Recluse', p. 182.

66 Watson, 'Religious reform', pp. 220-1.

67 In their essays, 'The legacy of Ancrene Wisse: translations, adaptations, influences and audience, with special attention to women readers' and 'Ancrene Wisse, religious reform and the late Middle Ages' respectively, in Companion.

68 Livarius Oliger, who edited the Dublin Rule, noted parallels with Ancrene Wisse, 'Regulae tres reclusorum et eremitarum Angliae saec. XIII-XIV', Antonianum, 3 (1928), 151-90, 299-320 (156) ('Regula Reclusorum Dubliniensis' edited at 170-90); Hope Emily Allen details these parallels as borrowings, pointing out that 'what is borrowed is in all cases practical admonitions', 'Further borrowings from 'Ancren Riwle”, Modern Language Review, 24 (1929), 1-15 (2). The Dublin rule does say that anchorites should wear neither white or black, 'nisi album vel nigrum', and continues 'vel grisum rusticanum' (183), but this is in the context of what sort of clothes are appropriate - the black or white habits are not being used as a metonymy for particular regular orders (cf. $A W$ Corpus Christi fo. $3^{\text {a }} 28$ ). See also Mari Hughes-Edwards, The 
Ideology of Medieval English Anchoritism (Cardiff, University of Wales Press, forthcoming).

69 Hope Emily Allen, 'Some fourteenth-century borrowings from 'Ancren Riwle", Modern Language Review, 18 (1923), 1-8 (1); and The Chastising of God's Children and the Treatise of Perfection of the Sons of God, ed. from the MSS by Joyce Bazire and Eric Colledge (Oxford: Basil Blackwell, 1957); the 'principal quotation' from Ancrene Wisse begins on p. 97, and see note p. 259.

70 Innes-Parker, 'Legacy', p. $158 \mathrm{ff}$.

71 AW Corpus Christi, fo. $47^{\mathrm{b}} 21-$ fo. $48^{\mathrm{a}} 1$. Although there is a reference to Saint Gregory on 'great temptation', the image of the wind blowing on the high hill probably originates with the author of Ancrene Wisse.

72 Allen, 'Some fourteenth-century borrowings', 2, 4.

73 Chastising, pp. 36-8.

74 Ibid., p. 221.

75 Allen, 'Some fourteenth-century borrowings', 2-3, and cf. InnesParker, 'Legacy', p. 158.

76 Innes-Parker, 'Legacy', pp. 163-4.

77 Ibid., p. 168.

78 Michael G. Sargent, Introduction to Nicholas Love, The Mirror of the Blessed Life of Jesus Christ: A Reading Text. A Revised Critical Edition, based on Cambridge University Library Add. MSS 6578 and 6686 (Exeter: University of Exeter Press, 2004), p. ix. Gillespie also suggests that it was 'one of the most widely disseminated works of vernacular devotion', 'Vernacular books of religion' (p. 322).

79 Sargent, Introduction, Mirror, p. xiii. Although the original Meditationes were not by the Franciscan Bonaventura, its spirituality and meditative style are Franciscan; Nicholas Love, however, was a Carthusian. His Mirror might be better considered an English version of the Meditationes than a translation.

80 Gerard Sitwell, 'Appendix: private devotions in the Ancrene Riwle', in The Ancrene Riwle, trans. M. B. Salu ([1955] University of Exeter Press, 1990), p. 196.

81 Love, Mirror, ed. Sargent, note to 31.12, p. 244. Cf. InnesParker, 'Nicholas Love's Mirror of the Blessed Life of Jesus Christ ... makes reference to Ancrene Wisse in a way that assumes the reader's familiarity with the text', 'Legacy', p. 147.

82 Watson, 'Religious reform', pp. 205-6.

83 Sargent, Introduction, Mirror, p. xv.

84 Gillespie, 'Vernacular books of religion', p. 327. 
85 R. I. Page, Matthew Parker and his Books, Sanders Lectures in Bibliography, University of Cambridge, 1990 (Kalamazoo, Mich.: Medieval Institute Publications, 1993), pp. 2 \& 43.

86 Christopher de Hamel, 'Collectors and Collecting in Cambridge' in The Cambridge Illuminations: Ten Centuries of Book Production in the Medieval West ed. by Paul Binski and Stella Panayotova (London: Harvey Miller, 2005), pp. 17-21 (p. 18). 


\section{Conclusion}

Our reading of Ancrene Wisse has traced a path from its construction in the reforming atmosphere of thirteenthcentury England, and the influences on it of Latin pastoralia, through its adaptation for later lay readers and incorporation in fourteenth-and fifteenth-century works of vernacular spirituality, to its place in the post-Reformation library of Matthew Parker. In Ancrene Wisse we see a working out and reconciling of the tension between academic, Latin-based theology and a vernacular spirituality with a tendency towards personal meditative practices and interior penitence. As I indicated in the Introduction, Ancrene Wisse is a shifting and variable work, subject to mouvance, as is common with medieval texts. The continuing popularity of Ancrene Wisse, which 'possibly circulated for a longer period than any other Middle English prose work', 1 and the expansion of its readership far beyond the boundaries of the anchorhold make consideration of the textual history of the work an important element in our reading of the text. The different versions all need to be taken into consideration in our understanding of what Ancrene Wisse is.

On the issue of textual scholarship and editing, Greetham comments that the practitioners of 'New Scholarship' 'claim that eclectic or critical editing's concentration on a single, uniform 'final intention' is a chimera, and that a textual editor would be better employed describing the 'process' rather than the apparent 'product' of literary composition'.2 Ancrene Wisse needs to be understood in this dynamic way; it is not a product of religious context and literary construction belonging to a static point in time, but rather a work in process over centuries, moving away from clerical and monastic writing in Latin and pointing towards a vernacular, 
devotional literature that was accessible to lay people. Ancrene Wisse had a continuing influence over other medieval devotional works for at least two centuries. Comparisons with Hilton's Scale of Perfection have been drawn, and although direct influence is more difficult to show, comparisons with the Scale and other works of English vernacular spirituality allow us to read Ancrene Wisse, not in opposition to the literature of the fourteenth century, but as a transitional work, on the cusp between monastic and lay spirituality.

Ancrene Wisse is in many ways a paradoxical work: it reconciles apparent contradictions in a dialectical movement. Its spirituality cannot be identified solely with public religious practices or with the personal, inner experience of the recluse, but is to be understood as a way of living based on a relationship with the divine. For the anchoresses, spirituality is the cultivation of the heart in its relationship with God; the misery and physical hardship they endure and the good they may do are to be used as tools with which to cultivate the heart. ${ }^{3}$ The anchoresses were a spiritual elite, living a dedicated religious life, but Ancrene Wisse was written, not in Latin, the language of the Church, but in English, the language of the people, and much of its guidance was applicable and relevant to devout lay people living in the world.

The spirituality of Ancrene Wisse could reach beyond the anchorhold and be relevant to lay people in the world, and yet the anchoresses for whom Ancrene Wisse was written rejected the world. For them, the anchorhold was both a haven, erecting a barrier against the temptations of the world, and the site in which the anchoress battled spiritual temptations. It provided the physical conditions - the protection and the privation - for the practice of a spirituality based on a personal relationship with Christ. The incarnational spirituality of Ancrene Wisse incorporates elements of bridal mysticism and eucharistic piety - suggesting both the embrace by and the consumption of Christ. It had at its heart meditation on that most paradoxical of concepts, and one which was the centre of their Christian faith - God made man. 


\section{CONCLUSION}

\section{Conclusion: Notes}

1 Edwards, 'The early English manuscripts', p. 103.

2 D. C. Greetham, Textual Scholarship: An Introduction (New York: Garland Publishing, 1994), p. 9.

3 'Al pet wa ant al pet heard pet we polieð o flesch, ant al pet god pet we eauer doð, alle swucche pinges ne beoð nawt bute as lomen to tilie wið pe heorte', $A W$ Corpus Christi, fo. 104a $15-17$. 


\title{
Bibliography
}

\author{
Abbreviations \\ CCCM Corpus Christianorum Continuatio Mediaevalis \\ CHMEL The Cambridge History of Medieval English Litera- \\ ture \\ EETS Early English Text Society \\ PL Patrologia Latina ed. J. P. Migne (Paris, 1844-73) \\ TEAMS Consortium for the Teaching of the Middle Ages
}

\section{Unpublished sources: manuscripts and theses}

Ancrene Wisse in MS Corpus Christi College Cambridge 402 'Cest li Riule' in MS. Bibliothèque de l'Arsenal, Paris 2058, f. $60^{\mathrm{ra}}-65^{\mathrm{vb}}$

Hours of Alice de Reydon in Cambridge University Library MS Dd.4.17

Baldwin, Mary, 'Ancrene Wisse and its Background in the Christian Tradition of Religious Instruction and Spirituality' (unpublished doctoral thesis, University of Toronto, 1974)

\section{Published primary sources}

Ancrene Wisse:

Ancrene Wisse ed. from MS Corpus Christi College Cambridge 402, ed. J. R. R. Tolkien, EETS 249 (London: Oxford University Press, 1962).

The English Text of the Ancrene Riwle, ed. from Cotton MS. Nero A. .xiv, ed. Mabel Day, EETS 225, (London: Oxford University Press, 1952). 
The English Text of the Ancrene Riwle, ed. from Cotton MS.

Titus D. xviii, ed. Frances Mack, EETS 252 (London:

Oxford University Press, 1963 (for 1962)).

The English Text of the Ancrene Riwle, ed. from Cotton

MS. Cleopatra C. vi, ed. E. J. Dobson, EETS 267 (London:

Oxford University Press, 1972).

The English Text of the Ancrene Riwle, ed. from Magdalene College, Cambridge, MS. Pepys 2498, ed. A. Zettersten EETS 274 (London: Oxford University Press, 1976).

The English Text of the Ancrene Riwle: The 'Vernon' Text, edited from Oxford, Bodleian Library MS Eng. poet. a. 1, ed. by Arne Zettersten and Bernhard Diensberg, Introduction by H. L. Spenser, EETS 310 (Oxford: Oxford University Press, 2000).

Ancrene Wisse, A corrected edition of the text in Cambridge,

Corpus Christi College, 402, with variants from other manuscripts, ed. Bella Millett, vol. 1, EETS OS vol. 325 (Oxford: OUP, 2006).

Ancrene Wisse, ed. by Robert Hasenfratz, TEAMS (Kalamazoo,

MI: Medieval Institute Publications, 2000).

Ancrene Wisse Parts Six and Seven, ed. by Geoffrey Shepherd

(1959; Exeter: University of Exeter Press, 1991).

The Ancrene Riwle (The Corpus MS.: Ancrene Wisse), trans. by

M. B. Salu (1955; Exeter: University of Exeter Press, 1990). Anchoritic Spirituality: Ancrene Wisse and Associated Works, trans. by Anne Savage and Nicholas Watson (New York: Paulist Press, 1991).

Ancrene Wisse: Guide for Anchoresses, trans. by Hugh White (London: Penguin, 1993).

Aelred of Rievaulx. De Institutione Inclusarum in Opera Omnia ed. by A. Hoste and C. H. Talbot, CCCM, 1 (Turnholt: Brepols, 1971); 'Rule of Life for a Recluse' trans. by Mary Paul Macpherson in Treatises; The Pastoral Prayer, Cistercian Fathers Series, 2 (Kalamazoo: Cistercian Publications, 1971). De Institutione Inclusarum: Two English Versions, ed. by John Ayto and Alexandra Barratt E.E.T.S. (London: Oxford University Press, 1984).

Alan of Lille. Liber in Distinctionibus Dictionum Theologicalium in PL 210. 
Alexander of Ashby, De artificioso modo predicandi in Alexandri Essebiensis Opera Theologica, ed. Franco Morenzoni, CCCM 188 (Turnhout: Brepols, 2004).

Alexander of Stavensby. Statutes in Councils and Synods with Other Documents Relating to the English Church, vol. 2, 1205-1313, ed. by F. M. Powicke and C. R. Cheney (Oxford: Clarendon Press, 1964).

Anselm. 'De Custodia Interioris Hominis' in Memorials of St. Anselm, ed. by R. W. Southern and F. S. Schmitt, Auctores Britannica Medii Aevi, 1 (London: Oxford University Press, for the British Academy, 1969), pp. 354-60.

Augustine. Confessions, ed. James O’Donnell (Oxford: Clarendon Press, 1992), 3 vols.; Confessions, trans. by R.

S. Pine-Coffin (London: Penguin, 1961).

Berengar. 'Jusjurandum quod in eadem synodo fecit Berengarius', in Sacrorum Conciliorum Nova, ed. by J. D. Mansi, (Venice, 1774), vol. 19.

Bernard of Clairvaux. S. Bernardi Opera, ed. by J. Leclercq et al. (Rome: Editiones Cistercienses, 1957-); On the Song of Songs trans. Kilian Walsh and Irene M. Edmonds (Kalamazoo, Mich.: Cistercian Publications, 1979); The Letters of Bernard of Clairvaux translated by Bruno Scott James (London: Burn Oates, 1953); Selected Works trans. G. R. Evans, intro. by J. leclercq (Mahwah: Paulist Press, 1987). The Book of Vices and Virtues ed. by W. Nelson Francis, EETS o.s. 217 (London: Oxford University Press, 1942). The Chastising of God's Children and the Treatise of Perfection of the Sons of God, ed. from the manuscripts by Joyce Bazire and Eric Colledge (Oxford: Basil Blackwell, 1957).

Cloud of Unknowing and The Book of Privy Counselling ed. from MS by Phyllis Hodgson, EEYS, o.s. 218 (London: Oxford University Press, 1944; rep. 1958).

Conciliorum Oecumenicorum Decreta, ed. J. Alberigo et al., 3rd ed. (Bologna: Istituto per le Scienze Religiose, 1973); trans. Norman Tanner in Decrees of the Ecumenical Councils. ed. Norman P. Tanner (London: Sheed and Ward, 1990), vol. 1.

'Consuetudines Fratrum Predicatorum' in De oudste Constituties van de Dominicanen: voorgeschiedenis, tekst, 
bronnen, ontstaan en ontwikkeling (1215-1237) met uitgave van de tekst, Bibliothèque de la Revue d'histoire ecclésiastique, fasc. 42 (Leuven: Leuvense Universitaire Uitgaven, 1965).

Councils and Synods with Other Documents Relating to the English Church, vol. 2, 1205-1313, ed. by F. M. Powicke and C. R. Cheney (Oxford: Clarendon Press, 1964).

Documents of the Christian Church, ed. by Henry Bettenson (London: Oxford University Press, 1943).

Edmund of Abingdon. Speculum Religiosorum and Speculum Ecclesie ed. by Helen P. Forshaw, Auctores Britannici Medii Aevi (London: Oxford University Press, for the British Academy, 1973).

Enchiridion Fontium Valdensium, ed. Giovanni Gonnet (Torre Pellice : Libreria Editrice Claudiana, 1958).

Francis of Assisi. 'Epistola II' in Opuscula Sancti Patris Francisci Assisiensis ed. PP. Collegii S. Bonaventurae (Quaracchi: Collegium S. Bonaventurae, 1904).

Gertrude of Helfta, Oenvres Spirituelles, vol. 3, Le Herault, Book 3, ed. and trans. by Pierre Doyere, Sources Chrétiennes No. 143 (Paris : Éditions du Cerf, 1968); Gertrude of Helfta, The Herald of Divine Love, trans. by Margaret Winkworth, Classics of Western Spirituality (Mahwah, N.J.: Paulist Press, 1993).

Gregory the Great. Homiliae in Hiezechihelem in Corpus Christianorum Series Latina, vol. 142.

Gregory the Great. [Grégoire le Grand] Règle Pastorale, Sources Chrétienne, 382 (Paris: Éditions du Cerf, 1992).

Guerric of Igny. Liturgical Sermons, vol. 2, trans. by monks of Mount St. Bernard Abbey, Cistercian authors series, 32 (Spencer, Mass: Cistercian Publications, 1971).

Hilton, Walter. The Scale of Perfection, ed. by Thomas H. Bestul, Middle English Texts Series, (Kalamazoo, Mich.: Medieval Institute Publications, 2000).

Hilton, Walter. 'Epistle on the Mixed Life' in English Mystics, ed. Windeatt.

Hubert of Sorbonne. Sermon 15 'Ad beginas in festo beati Iohannis in mane', in 'La Prédication' ed. Bériou.

James of Varazze. Jacob de Voragine, The Golden Legend: Readings on the Saints trans. by William Granger Ryan, 
2 vols. (Princeton, N. J.: Princeton University Press, 1993); Jacobus de Voragine, The Golden Legend: Selections, trans. by Christopher Stace (London: Penguin, 1998).

James of Vitry. Vita Mariae Oigniacensis, in Acta Sanctorum June, vol. 4, ed. by D. Papebrochius (Antwerp, 1707); Jacques de Vitry, The Life of Marie d'Oignies, trans. by Margot H. King, Peregrina Papers Series, 3 (Toronto: Peregrina, 1993).

James of Vitry. Sermo 73 'Ad pueros et adolescentes' in Analecta Spicilegii Solesmensis, Altera Continuatio, v. 2, ed. Pitra (Typis Tusculanis, 1888); Sermon 73 trans. John Shinners, Medieval Popular Religion, 1000-1500: A Reader (Peterborough, Ontario: Broadview Press, 1997).

James of Vitry. Sermones in Epistolas et Euangelia dominicalia totius anni (Antwerp: In Aedibus Viduae \& Haeredum Ioannis Stelsiij, 1575).

James of Vitry. Historia occidentalis, ed. John F. Hinnebusch, Spicilegium Friburgense vol. 17 (Fribourg: The University Press, 1972).

James of Vitry. The Exempla of Jacques de Vitry, ed. Thomas Frederick Crane, for the Folk-Lore Society (London: David Nutt, 1890).

John of Salisbury. Memoirs of the Papal Court, trans. by M. Chibnall (London: Thomas Nelson, 1956).

Jordan of Saxony. On the Beginnings of the Order of Preachers ed. \& trans. by Simon Tugwell, Dominican Sources: New Editions in English (Dublin: Dominican Publications, 1982). Julian of Norwich, A Revelation of Love, ed. by Marion Glasscoe (Exeter: University of Exeter Press, rev. ed., 1993). Julian of Norwich. The Writings of Julian of Norwich: A Vision Showed to a devout Woman and A Revelation of Love, ed. by Nicholas Watson and Jacqueline Jenkins (University Park, PA: Pennsylvania State University Press, 2006).

Kempe, Margery. The Book of Margery Kempe, ed. by Barry Windeatt (Harlow: Pearson Education, 2000).

Langland, William, Piers Plowman, B text, ed. by Walter Skeat (London: Oxford University Press for EETS, 1869); Piers Plowman, a translation of the B-text by A. V. C. Schmidt (Oxford: Oxford University Press, 1992). 
Lay-Folks Mass-Book, ed. by Thomas Frederick Simmons, EETS, O.S. 71 (London: Trubner, 1879).

Libellus de Diversis Ordinibus et Professionibus qui sunt in Aecclesia, ed. and trans. by G. Constable and B. Smith (Oxford: Clarendon Press, 1972).

The Life of Christina of Markyate: A Twelfth Century Recluse, ed. \& trans. by C. H. Talbot (Oxford: Clarendon Press, 1959).

Love, Nicholas. The Mirror of the Blessed Life of Jesus Christ: A Reading Text. A Revised Critical Edition, based on Cambridge University Library Add. MSS 6578 and 6686, ed. by Michael G. Sargent (Exeter: University of Exeter Press, 2004).

Matthew Paris, Chronica Majora, in The Chronicles and Memorials of Great Britain and Ireland During the Middle Ages (Rolls Series), vol. 4, ed. by Henry Richards Luard (1877; Wiesbaden: Kraus reprint, 1964).

Matthew Paris, Historia Anglorum, vol. 2, ed. by Sir Frederic Madden (Rolls Series, 1866; Wiesbaden: Kraus reprint, 1971).

Mechthild of Magdeburg. Selections from The Flowing Light of the Godhead, Library of Medieval Women (Cambridge: Brewer, 2003), trans. Elizabeth A. Andersen; Flowing Light of the Divinity, trans. by Christiane Mesch Galvani, Garland Library of Medieval Literature, Series B, vol. 72 (New York: Garland Publishing, 1991).

Medieval English Prose for Women: Selections from the Katherine Group and Ancrene Wisse, ed. by Bella Millett and Jocelyn Wogan-Browne (Oxford: Clarendon Press, rev. ed., 1992).

The Middle English 'Mirror': An Edition Based on Bodleian

Library, MS Holkham misc. 40, ed. by Kathleen Marie Blumreich, Arizona Center for Medieval and Renaissance Studies (Turnhout: Brepols, 2002) .

Nicolas de Gorran, Sermon 31 in Bériou, 'La Prédication', ed.

Beriou.

Old English Homilies and Homiletic Treatises, First Series, ed.

Richard Morris (London: Early English Text Society, 1868). Peter Abelard's Ethics, ed. \& trans. by D. E. Luscombe (Oxford: Clarendon Press, 1971). 
'La plus ancienne Règle de Béguinage de Bruges', ed. by $\mathrm{R}$. Hoornaert, Annales de la société d'émulation de Bruges, 72 (1929), 1-79.

Raymond Pennaforte. Raymond de Penaforte, Summa de poenitentia (Rome, 1603; facs. Farnborough: Gregg Press, 1967); Raymond of Penyafort, Summa on Marriage, trans. Pierre J. Payer (Toronto: Pontifical Institute of Mediaeval Studies, 2005).

Richard of St. Victor. Richard of St. Victor, 'De Gratia Contemplationis', PL 196; The Twelve Patriarchs, The Mystical Ark, Book Three of the Trinity, trans. by Grover A. Zinn, Classics of Western Spirituality (London: S.P.C.K., 1979).

Robert of Basevorn, 'Forma praedicandi' in Th.-M. Charland, Artes Praedicandi (Paris \& Ottawa: Publications de l'Institut d'Études Médiévales d'Ottawa, 1936), pp. 232-323; trans. by Leopold Krul in Three Medieval Rhetorical Arts ed. James J. Murphy, (Berkeley: University of California Press, 1971 pp. 114-215.

Robert Courson. Summa, ed. V. L. Kennedy, 'Robert Courson on Penance', Mediaeval Studies, 7 (1945), 291-336 (294).

Robert Grosseteste. Epistolae, in Chronicles and Memorials of Great Britain and Ireland during the Middle Ages, vol. 25, ed. Henry Richards Luard (1861; Wiesbaden: Kraus reprint, 1965).

Robert of Sorbon. 'Sermo M. Roberti de Sorbona ad Theologos' in Historia Universitatis Parisiensis, ed. by César Égasse du Boulay, 6 vols. (Paris, 1665-73), vol. 3.

Rolle, Richard. 'The Mendynge of Lyfe' in English Mystics, ed. Windeatt .

The Rule of Benedict: A Guide to Christian Living, (Latin text established by H. Rochais \& E. Manning), trans. by monks of Glenstal Abbey, with commentary by George Holzhar (Dublin: Four Courts Press, 1994).

Les Statuts de Prémontré au Milieu du XIIe siècle, ed. by Pl. F. Lefèvre and W. M. Grauwen, Bibliotheca Analectorum, Praemonstratensium Fasc. 12 (Averbode : Praemonstratensia, 1978).

Stephen Langton. Statutes of Canterbury in Councils and Synods. 
Thomas of Chobham. Sermones ed. by Franco Morenzoni, CCCM 82A (Turnhout: Brepols, 1993).

Thomas of Chobham. Summa Confessorum, ed by F. Bloomfield, Analecta mediaevalia Namurcensia, 25 (Louvain: Éditions Nauwelaerts, 1968).

Thomas of Chobham, Summa de arte praedicandi, ed.

F. Morenzoni, CCCM, 82 (Turnhout: Brepols, 1988).

Thomas of Chobham. Summa de commendatione virtutum et extirpatione vitiorum, ed. by $\mathrm{F}$. Morenzoni, CCCM vol. 82B (Turnholt: Brepols, 1997).

Thomas of Eccleston. Tractatus de Adventu Fratrum Minorum in Angliam, ed. by A. G. Little (Manchester: Manchester University Press, 1951).

Vices and Virtues: A Middle-English dialogue of about 1200 A.D. ed. with trans. from the Stowe MS 240, by F. Holthausen, EETS 89 (London: Trubner, 1888).

William Peraldus. Summa Virtutum de Remediis Anime ed. by Siegfried Wenzel, the Chaucer Library (Athens: University of Georgia Press, 1984).

\section{Secondary material}

Ackerman, Robert W., 'The liturgical day in Ancrene Riwle', Speculum 53 (1978), 734-44.

Allen, Hope Emily, 'Some fourteenth century borrowings from "Ancren Riwle", Modern Language Review, 18 (1923), $1-8$.

_ 'Further borrowings from "Ancren Riwle", Modern Language Review, 24 (1929), 1-15.

Backhouse, Janet, Books of Hours (London: The British Library, 1985).

Baker, Denise Nowakowski, Julian of Norwich's Showings: From Vision to Book (Princeton, N.J.: Princeton University Press, 1994).

Baldwin, J. W., Masters, Princes and Merchants: The Social Views of Peter the Chanter and His Circle, 2 vols. (Princeton, N.J.: Princeton University Press, 1970).

Barber, Richard, Penguin Guide to Medieval Europe (London: Penguin, 1984). 
Barratt, Alexandra, 'The five wits and their structural significance in Part II of Ancrene Wisse', Medium Aevum, 56 (1987), 12-24.

- 'Small Latin? The post-Conquest learning of English religious women' in Siân Echard and Gernot R. Wieland (eds), Anglo-Latin and its Heritage: Essays in Honour of A. G. Rigg on his 64th Birthday, Publications of the Journal of Medieval Latin, 4 (Turnhout: Brepols, 2001), pp. 51-65. Bataillon, Louis-Jacques, 'Similitudines et Exempla dans les sermons du XIII siècle' in Katherine Walsh and Diana Wood (eds), The Bible in the Medieval World: Essays in Memory of Beryl Smalley, Ecclesiastical History Society (Oxford: Basil Blakwell, 1985), pp. 191-205.

Sister Benedicta [Ward], 'Julian the Solitary' in K. Leech and Sr. Benedicta (eds), Julian Reconsidered (SLG Press, 1988), 11-31.

Bennett, J.A.W., Middle English Literature, ed. by Douglas Gray (Oxford: Clarendon Press, 1986).

Bériou, Nicole, 'La Prédication au béguinage de Paris pendant l'année liturgique 1272-33', Recherches Augustiniennes, 13 (1978).

Bériou N. and D. L. d'Avray, 'The image of the ideal husband in thirteenth-century France' in N. Bériou, D. L. d'Avray et al. (eds), Modern Questions about Medieval Sermons: Essays on Marriage, Death, History and Sanctity (Spoleto: Centro Italiano di Studi Sull'Alto Medioevo, 1994), pp. 31-69.

Bériou, Nicole, 'Les sermons Latin après 1200' in Kienzle, ed. The Sermon, pp. 363-447.

Biller, Peter, 'Words and the medieval notion of "Religion"', Journal of Ecclesiastical History, 36 (1985), pp. 351-69.

Binski, Paul, Becket's Crown: Art and Imagination in Gothic England 1170-1300 (New Haven: Yale University Press, 2004).

Bird, Jessalyn, 'The religious's role in a post-fourth-Lateran World: Jacques de Vitry's sermones ad status and Historia Occidentalis' in Carolyn Muessig (ed.), Medieval Monastic Preaching (Leiden: Brill, 1998), pp. 209-29.

Bloomfield, Morton, The Seven Deadly Sins: An Introduction to the History of a Religious Concept, with Special Reference 
to Medieval English Literature (Michigan State College Press, 1952).

Bolton, Brenda M., 'Some thirteenth-century women in the

Low Countries: a special case?', Nederlands Archief voor Kerkgeschiedenis, 61 (1981), 7-29.

Bolton, Brenda, 'Thirteenth-century religious women: further

Rreflections on the Low Countries "Special Case"' in Dor et al. (eds), New Trends, pp. 129-57.

Boyle, Leonard, 'The fourth Lateran Council and manuals of popular theology' in Thomas J. Heffernan (ed.), The Popular Literature of Medieval England (Knoxville: University of Tennessee Press, 1985), pp. 30-43.

Bremond, Claude, Jacques le Goff and Jean-Claude Schmitt, L' "Exemplum », Typologie des Sources du Moyen Age Occidental, Fasc. 40 (Turnhout : Brepols, 1982).

Butler, Cuthbert, Western Mysticism, (1922; London: Arrow Books, pbk ed. 1960).

Bynum, Caroline Walker, Jesus as Mother: Studies in the Spirituality of the High Middle Ages (Berkeley: University of California Press, 1982).

- Holy Feast and Holy Fast: The Religious Significance of Food to Medieval Women (Berkeley: University of California Press, 1987).

- Fragmentation and Redemption: Essays on Gender and the Human Body in Medieval Religion (New York: Zone Books, 1992).

The Cambridge History of Medieval English Literature, ed. David Wallace (Cambridge: Cambridge University Press, 1999).

Clanchy, M. T., From Memory to Written Record: England 1066-1307 (1979; Oxford: Blackwell, 1993).

Coakley, John, 'Friars as confidents of holy women in medieval Dominican hagiography', in Renate Blumenfeld-Kosinski and Timea Szell (eds), Images of Sainthood in Medieval Europe (Ithaca: Cornell University Press, 1991), 222-46.

Colish, Marcia L., The Mirror of Language: A Study in the Medieval Theory of Knowledge (New Haven: Yale University Press, 1968).

Colledge, Eric [Edmund], The Medieval Mystics of England (London: Murray, 1962). 
- 'The Recluse: A Lollard interpolated version of the Ancrene Riwle', Review of English Studies, 15 (1939), $1-15 \& 129-45$.

Constable, Giles, 'Aelred of Rievaulx and the nun of Watton: an episode in the early history of the Gilbertine order', in Derek Baker (ed.), Medieval Women (Oxford: Blackwell, 1978), pp. 205-26.

- The Reformation of the Twelfth Century (Cambridge: Cambridge University Press, 1996; pbk. ed., 1998).

Three Studies in Medieval Religious and Social Thought (Cambridge: Cambridge University Press, 1995; pbk. ed., 1998).

Creytens, Raymond, 'Les constitutions des Frères Prêcheurs dans la redaction de S. Raymond de Peñafort (1241)' in Archivum Fratrum Praedicatorum, 18 (1948), pp. 5-68.

Dahood, Roger, 'Ancrene Wisse, the Katherine Group, and the Wohunge Group' in Middle English Prose: A Critical Guide to Major Authors and Genres ed. A. S. G. Edwards (New Brunswick, 1984), pp. 1-21.

Dahood, Roger, 'Design in Part 1 of Ancrene Riwle', Medium Aevum, 56 (1987), 1-11.

_ 'The use of coloured initials and other division markers in early versions of Ancrene Riwle', in Edward Donald Kennedy, Ronald Waldron and Joesph S. Wittig (eds), Medieval English Studies Presented to George Kane (Woodbridge: Brewer, 1988), pp. 79-97.

_ 'The current state of Ancrene Wisse group studies', Medieval English Studies Newsletter, 36 (1997), 6-14. d'Avray, D., The Preaching of the Friars: Sermons diffused from Paris before 1300 (Oxford: Clarendon, 1985).

de Hamel, Christopher, 'Collectors and collecting in Cambridge' in Paul Binski and Stella Panayotova (eds), The Cambridge Illuminations: Ten Centuries of Book Production in the Medieval West (London: Harvey Miller, 2005), pp. 17-21.

Devlin, Dennis, 'Feminine lay piety in the high Middle Ages: The Beguines', in Nicholls and Shank (eds), Distant Echoes, pp. 183-96.

Dobson, E. J., 'The date and composition of Ancrene Wisse', Proceedings of the British Academy, 52 (1966), (London: pub. for the British Academy by the OUP, 1967), 181-208. 
Dobson, E. J., The Origins of Ancrene Wisse (Oxford: Clarendon Press, 1976)

Dondaine, Antoine, 'Guillaume Peyraut: vie et œuvres', Archivum Fratrum Praedicatorum, 18 (1948), 162-236.

Dor, Juliette, Lesley Johnson and Jocelyn Wogan-Browne (eds). New Trends in Feminine Spirituality: The Holy Women of Liège and their Impact, Medieval Women: Texts and Contexts, 2 (Turnholt: Brepols, 1999).

Doyle, A. I., Introduction to The Vernon Manuscript: A facsimile of Bodleian Library, Oxford, MS Eng. Poet. a. I (Cambridge: Brewer, 1987).

Duffy, Eamon, The Stripping of the Altars: Traditional Religion in England c.1400-c.1580 (New Haven: Yale University Press, 1992).

Edwards, A. S. G., 'The early English manuscripts and early readers of Ancrene Wisse', in Wada (ed.), Companion, pp. 103-12.

Elkins, Sharon K., Holy Women of Twelfth Century England (Chapel Hill: North Carolina Press, 1988)

Erickson, Carolly, The Medieval Vision: Essays in History and Perception (New York: Oxford University Press, 1976)

Evans, G. R. (ed.), The Medieval Theologians (Oxford: Blackwell, 2001)

- Alan of Lille: The Frontiers of Theology in the Later Twelfth Century (Cambridge: Cambridge University Press, 1983)

Fleming, John, 'The Friars and medieval English literature' in CHMEL, pp. 349-75.

Frankl, Paul, The Gothic: Literary Sources and Interpretations through Eight Centuries (Princeton, N.J.: Princeton University Press, 1960)

Gardner Helen, 'Walter Hilton and the mystical tradition in England' in Essays and Studies, 22 (1936) 103-27.

Galloway, Penny, 'Neither mraculous nor astonishing: the devotional practice of Beguine communities in French Flanders', in Dor et al. (eds), New Trends, pp. 107-27. " "Life, Learning and Wisdom": the forms and functions of Beguine education', in George Ferzoco and Carolyn Muessig (eds), Medieval Monastic Education (London: Leicester University Press, 2000), pp. 153-67. 
Georgianna, Linda, The Solitary Self: Individuality in the Ancrene Wisse (Cambridge: Harvard University Press, 1981). Gibbs, Marion and Jane Lang, Bishops and Reform 1215-1271, with Special Reference to the Lateran Council of 1215 (London: Oxford University Press, 1934).

Gillespie, Vincent, 'Vernacular books of religion', in Jeremy Griffiths and Derek Pearsall (eds), Book Production and Publishing in Britain, 1375-1475 (Cambridge: Cambridge University Press, 1989), pp. 317-44.

Goering, Joseph, 'The invention of transubstantiation', Traditio 46 (1991), 147-170.

- William de Montibus: The Schools and the Literature of

Pastoral Care (Toronto: Pontifical Institute of Mediaeval Studies, 1992).

'Pastoralia: The popular literature of the care of souls' in Medieval Latin, pp. 670-6.

Grabes, Herbert, The Mutable Glass: Mirror Imagery in Titles and Texts of the Middle Ages and English Renaissance, tr. Gordon Collier (Cambridge: Cambridge University Press, 1982).

Graef, Hilda, Mary: A History of Doctrine and Devotion (1963; London: Sheed and Ward, 1985).

Grayson, Janet, Structure and Imagery in Ancrene Wisse (Hanover, N.H.: University Press of New England, 1974).

Greetham, D. C., Textual Scholarship: An Introduction (New York: Garland Publishing, 1994).

'Introduction: out of the text and into the margins', in D. C. Greetham (ed.), The Margins of the Text (Ann Arbor: University of Michigan Press, 1997), pp. 1-5.

Grundmann, Herbert, Religious Movements in the Middle Ages: The Historical Links between Heresy, the Mendicant Orders, and the Women's Religious Movement in the Twelfth and Thirteenth Century, trans. by Steven Rowan (Notre Dame: University of Notre Dame Press, 1995).

Gunn, Cate, "Efter the measse-coss, hwen the preost sacre_": when is the moment of ecstasy in Ancrene Wisse?', Notes And Queries, 246, N.S., 48 (2001), 105-8.

Gunn, Cate, 'Ancrene Wisse: a modern lay person's guide to a medieval religious text', Magistra, 8 (2002) 3-25. 
— 'Beyond the tomb: Ancrene Wisse and lay piety', in Anchorites, Wombs and Tombs, pp. 161-71.

- "Private meditations and public discourse: Ancrene Wisse and sermon rhetoric' in Liz Herbert McAvoy (ed.), Rhetoric of the Anchorbold: Place, Space and Body within the Discourses of Enclosure (University of Wales Press, forthcoming 2008)

Gy, Pierre-Marie, 'Liturgy and spirituality ii: sacraments and liturgy in Latin Christianity', trans. by Craig McKee, in Bernard McGinn and John Meyendorff (eds), Christian Spirituality I: Origins to the Twelfth Century, vol. 16. of World Spirituality: An Encyclopedic History of the Religious Quest (London: Routledge and Kegan Paul, 1986), pp. 365-82.

Hahn, Thomas, 'Early middle English' in CHMEL, pp. 61-91 Haren, Michael, Medieval Thought: The Western Intellectual Tradition from Antiquity to the Thirteenth Century (Basingstoke: Macmillan, 1985)

Heslop, T. A., 'Attitudes to the visual arts: the evidence from written sources', in Jonathan Alexander and Paul Binski (eds), Age of Chivalry: Art in Plantagenet England, 1200-1400 (London: Weidenfeld and Nicolson for the Royal Academy of Arts, 1987), pp. 26-32.

Hilton, R. H., A Medieval Society: The West Midlands at the End of the Thirteenth Century (London: Weidenfeld and Nicolson, 1966).

Holdsworth, C. J., 'Christina of Markyate'. in Derek Baker (ed.), Medieval Women (Oxford: Blackwell, 1978), pp. 185-204.

Hughes-Edwards, Mari, 'Hedgehog skins and hairshirts: the changing role of asceticism in the anchoritic ideal', Mystics Quarterly, 28 (2002), 6-25.

Innes-Parker, Catherine, 'The Lady and the King: Ancrene Wisse's parable of the royal wooing re-examined', English Studies, 75 (1994), 509-22.

_ The legacy of Ancrene Wisse: translations, adaptations, influences and audience, with special attention to women readers', in Wada (ed.), Companion, pp. 145-73.

Johnson, Lesley and Jocelyn Wogan-Browne, 'National, world and women's history', in The Cambridge History of Medieval English Literature, pp. 92-121. 
Jungmann, Joseph, The Mass of the Roman Rite: its Origins and Development, trans. Francis A. Brunner, 2 vols. (1955; Westminster, Maryland: Christian Classics, 1986).

Kennedy, V. L., 'The moment of consecration and the elevation of the host', Mediaeval Studies, 6 (1944), 21-50.

Kienzle, Beverly Mayne (ed.), The Sermon, Typologie des Sources du Moyen Âge Occidental, Fasc. 81-3 (Turnhout: Brepols, 2000).

Knowles David, The English Mystical Tradition (London: Burns and Oates, 1961).

Lawrence, C. H., Medieval Monasticism (London: Longman, 1984).

- The Friars: The Impact of the Mendicant Movement on Western Society (London: Longman, 1994).

le Goff, Jacques, The Medieval Imagination, trans. by Arthur Goldhammer (Chicago: University of Chicago Press, 1988; pbk. ed., 1992).

Leclercq, Jean, The Love of Learning and the Desire for God, trans. by Catharine Misrahi (New York: Fordham University Press, 1961).

Louth, Andrew, The Origins of the Christian Mystical Tradition from Plato to Denys (Oxford: Clarendon Press, 1981).

Luscombe, D. E., 'Peter Abelard', in Peter Dronke (ed.), A History of Twelfth-Century Western Philosophy, pp. 279-307.

Macy, Gary, The Theologies of the Eucharist in the Early Scholastic Period: A Study of the Salvific Function of the Sacrament according to the Theologians c.1080-c.1220 (Oxford: Clarendon Press, 1984).

- The Banquet's Wisdom: A Short History of the Theologies of the Lord's Supper (Mahwah, N.J.: Paulist Press, 1992).

_ 'The dogma of transubstantiation in the Middle Ages', Journal of Ecclesiastical History, 45 (1994), 11-41.

Mantello, F. A. C. and A. G. Rigg (eds), Medieval Latin: An Introduction and Bibliographical Guide (Washington, D.C.: Catholic University of America Press, 1996).

McAvoy, Liz Herbert and Mari Hughes-Edwards (eds), Anchorites, Wombs and Tombs: Intersections of Gender and Enclosure in the Middle Ages (Cardiff: University of Wales Press, 2005) 
McDonnell, Ernest W., The Beguines and Beghards in Medieval Culture with Special Emphasis on the Belgian Scene (New Brunswick, N.J.: Rutgers University Press, 1954).

Meale, Carol M. (ed.), Women and Literature in Britain, 1150-1500 (Cambridge: Cambridge University Press, 1993; 2 ${ }^{\text {nd }}$ ed., 1996).

Millett, Bella, 'The origins of Ancrene Wisse: new answers, new questions', Medium Aevum, 61 (1992), 206-28.

— 'Mouvance and the medieval author: re-editing Ancrene Wisse' in A. J. Minnis (ed.), Late-Medieval Religious Texts and their Transmission (Cambridge: Brewer, 1993).

- Ancrene Wisse, The Katherine Group, and The Wooing Group, Annotated Bibliographies of Old and Middle English Literature, vol. 2 (Cambridge: Brewer, 1996).

— 'Women in no man's land: English recluses and the development of vernacular literature in the twelfth and thirteenth centuries', in Women and Literature in Britain, pp. 86-103.

- 'Ancrene Wisse and the conditions of confession', English Studies, 80 (1999), 193-215.

_ 'Ancrene Wisse and the Book of Hours', in Writing Religious Women: Female Spiritual and Textual Practices in Late Medieval England, ed by Denis Renevey and Christiania Whitehead (Cardiff: University of Wales Press, 2000), 21-40.

_ 'Ancrene Wisse and the life of perfection', Leeds Studies in English 33 (2002), 53-76.

- 'The Genre of Ancrene Wisse' in Wada (ed.), Companion, pp. 29-44.

- 'The pastoral context of the Lambeth and Trinity Homilies' forthcoming in Wendy Scase (ed.), Vernacular Manuscript Books of the English West Midlands from the Conquest to the Sixteenth Century (Turnhout: Brepols).

Morris, Colin, The Papal Monarchy: The Western Church from 1050 to 1250 (Oxford: Clarendon Press, 1989; Clarendon pbk, 1991).

Morson, John, Christ the Way:The Christology of Guerric of Igny, Cistercian Studies, 25 (Kalamazoo, Mich.: Cistercian Publications, 1978). 
Mosher, Joseph Albert, The Exemplum in the Early Religious and Didactic Literature of England (New York: Columbia University Press, 1911).

Muessig, Carolyn, 'Paradigms of sanctity for thirteenthcentury women' in Models of Holiness in Medieval Sermons, Textes et Études du Moyen Âge, 5 (Louvain-laNeuve: Fédération Internationale des Instituts d'Études Médiévales, 1996), pp. 85-102.

Muessig, Carolyn, The Faces of Women in the Sermons of Jacques de Vitry (Toronto: Peregrina, 1999).

Mulchahey, Michèle, 'First the Bow is Bent in Study .. .' Dominican Education before 1350, Studies and Texts, 132 (Toronto: Pontifical Institute of Mediaeval Studies, 1998).

Mulder-Bakker, Anneke B., Lives of the Anchoresses; The Rise of the Urban Recluse in Medieval Europe, trans. Myra Heerspink Scholz (Philadelphia: University of Pennsylvania Press, 2005).

Murk-Jansen, Saskia, Brides in the Desert: The Spirituality of the Beguines (London: Darton, Longman and Todd, 1998).

Murphy, James J., Rhetoric in the Middle Ages: A History of Rhetorical Theory from St. Augustine to the Renaissance (Berkeley: University of California Press, 1974).

Murphy, James, 'Rhetoric' in Medieval Latin, ed. Mantello \& Rigg, pp. 629-68.

Newhauser, Richard, The Treatise on Vices and Virtues in Latin and the Vernacular, Typologie des Sources du Moyen Age Occidental, Fasc. 68 (Turnhout: Brepols, 1993).

Newhauser, Richard (ed.), In the Garden of Evil: The Vices and Culture in the Middle Ages, ed. by (Toronto: Pontifical Institute of Mediaeval Studies, 2005).

Newman, Barbara, 'Flaws in the golden bowl: gender and spiritual formation in the twelfth century', Traditio, 45 (1989-90), pp. 111-46; rep. in From Virile Woman to WomanChrist: Studies in Medieval Religion and Literature (Philadelphia: University of Pennsylvania Press, 1995).

Nicholls, John A. and Lillian Thomas Shank (eds), Distant Echoes: Medieval Religious Women, vol. 1 (Kalamazoo, Mich: Cistercian Publications, 1984).

O'Carroll, Mary, A Thirteenth-Century Preacher's Handbook: Studies in MS Laud Misc. 511 (Toronto: Pontifical Institute of Medieval Studies, 1997). 
Oliger, Livarius, 'Regulae tres reclusorum et eremitarum Angliae saec. XIII-XIV', Antonianum, 3 (1928), 151-90 \& 299-320.

O'Loughlin, Thomas, 'Penitentials and pastoral care', in G. R. Evans (ed.), A History of Pastoral Care (London: Cassell, 2000), pp. 93-111.

Page, R. I., Matthew Parker and his Books, Sanders Lectures in Bibliography, University of Cambridge, 1990 (Kalamazoo, Mich.: Medieval Institute Publications, 1993).

Panofsky, Erwin, Gothic Architecture and Scholasticism (Cleveland: World Publishing, 1957).

Parkes, M. B., 'The literacy of the laity', in David Daiches \& Anthony Thorlby (eds), Literature and Western Civilization: The Medieval World (London: Aldus Books, 1973), 555-77. Pearsall, Derek, Introduction to Derek Pearsall (ed.), Studies in the Vernon Manuscript (Cambridge: Brewer, 1990), pp. ix-xi.

Platt, Colin, The English Medieval Town (London: Granada, 1976; Paladin pbk. ed., 1979).

Raw, Barbara, 'Prayers and devotions in the Ancrene Wisse' in Chancer and Middle English Studies in Honour of Rossell Hope Robbins, ed. by Beryl Rowland (London: George Allen and Unwin, 1974), pp. 260-71.

Riddy, Felicity, "Women talking about the things of God": a late medieval sub-culture', in Women and Literature in Britain, 104-27.

Riehle, Wolfgang, The Middle English Mystics, trans. by Bernard Standing (London: Routledge and Kegan Paul, 1981).

Roberts Phyllis B., 'The Ars Praedicandi and the medieval sermon' in Carolyn Muessig (ed.), Preacher, Sermon and Audience in the Middle Ages (Leiden: Brill, 2002), pp. 41-62.

Robertson, Elizabeth, 'Savouring "Scientia": the medieval anchoress reads Ancrene Wisse', in Wada (ed.), Companion, pp. 113-44.

Robertson, Elizabeth, "“This living hand": thirteenth-century female literacy, materialist immanence, and the reader of Ancrene Wisse', Speculum, 78 (2003), 1-36. 
Rosof, Patricia, 'The anchoress in the twelfth and thirteenth centuries' in Lillian Thomas Shank and John A. Nicholls (eds), Peaceweavers: Medieval Religious Women, vol. 2 (Kalamazoo, Mich.: Cistercian publications, 1987).

Rouse, Richard H. and Mary A. Rouse, 'Statim invenire: schools, preachers, and new attitudes to the page' in Robert Benson and Giles Constable with Carol D. Lanham (eds), Renaissance and Renewal in the Twelfth Century (Toronto: University of Toronto Press, 1991), pp. 201-25.

Rubin, Miri, 'What did the Eucharist mean to thirteenthcentury villagers?' in P. R. Coss and S. D. Lloyd (eds), Thirteenth-Century England, IV, Proceedings of the Newcastle-upon tyne Conference, 1991 (Woodbridge: Boydell and Brewer, 1992), pp. 47-57.

Rubin, Miri, Corpus Christi: The Eucharist in Late Medieval Culture (Cambridge: Cambridge University Press, 1991).

Rygiel, Dennis, 'Structure and style in Part Seven of Ancrene Wisse', Neuphilologische Mitteilungen, 81 (1980), 47-56.

- 'A holistic approach to the style of Ancrene Wisse', Chancer Review 16 (1982), 270-81.

Saenger, Paul, Space Between Words: The Origins of Silent Reading (Stanford: Stanford University Press, 1997).

Savage, Anne, 'The solitary heroine: aspects of meditation and mysticism in Ancrene Wisse, the Katherine Group, and the Wooing Group' in William F. Pollard and Robert Boenig (eds), Mysticism and Spirituality in Medieval England (Cambridge: Brewer, 1997), pp. 63-83.

Savage, Anne, 'The communal authorship of Ancrene Wisse', in Wada (ed.), Companion, pp. 45-55.

Sheerin, Daniel, 'The Liturgy' in Medieval Latin, pp. 157-82. Simons, W., 'The Beguine movement in the southern Low Countries; a reassessment', Bulletin De L'Institute Historique Belge de Rome, 59 (1989), 63-101.

Smalley, Beryl, The Study of the Bible in the Middle Ages (1952; Notre Dame, Indiana: University of Notre Dame Press, 1964).

Southern, R. W., Western Society and the Church in the Middle Ages (London: Hodder and Stoughton, 1970).

Spencer, H. Leith, English Preaching in the Late Middle Ages, (Oxford: Clarendon Press, 1993). 


\section{BIBLIOGRAPHY}

Spencer, H. L., 'Middle English sermon' in The Sermon, dir. by Kienzle, pp. 597-660.

Talbot, C. H., 'Some notes on the dating of the Ancrene Riwle', Neophilologus, 40 (1956), 38-50.

Thompson, Sally, Women Religious: The Founding of English

Nunneries after the Norman Conquest (Oxford: Clarendon Press, 1991).

Tugwell, Simon, The Way of the Preacher (London: Darton, Longman and Todd, 1979).

— Introduction to Early Dominicans: Selected Writings (Mahwah: Paulist Press, 1982).

Tuma, George Wood, The Fourteenth Century Mystics: A Comparative Analysis, 2 vols. (Salzburg: Institut für Englishche Sprache und Literatur, 1977).

Utley, Frances Lee, 'Dialogues, debates and catechisms', in $A$ Manual of the Writings in Middle English 1050-1500, vol. 3, (Newhaven, CT.: Connecticut Academy of Arts and Sciences, 1972), pp. 669-745.

Vauchez, André, La Spiritualité du Moyen Age Occidental VIIIe-XIIe Siècles, Collection S. U. P. (Paris: Presses Universitaires de France, 1975); trans. as The Spirituality of the Medieval West from the Eighth to the Twelfth Century by Colette Friedlander, Cistercian Studies No. 145 (Kalamazoo: Cistercian Publications, 1993).

Venarde, Bruce, Women's Monasticism and Medieval Society: Nunneries in France and England, 890-1215 (Ithaca: Cornell University Press, 1997).

Voaden, Rosalynn, God's Words, Women's Voices: The Discernment of Spirits in the Writing of Late-Medieval Women Visionaries (York: York Medieval Press, 1999). von Nolcken, Christina, 'The Recluse and its readers: some observations on a Lollard interpolated version of Ancrene Wisse, in Wada (ed.), Companion, pp. 175-96.

Wada, Yoko, 'Dominican authorship of Ancrene Wisse: the evidence of the Introduction', in Y. Wada (ed.), A Book of Ancrene Wisse (Suita, Osaka: Kansai University Press, 2002), pp. 95-107.

Wada, Yoko (ed.), A Companion to Ancrene Wisse (Cambridge: Brewer, 2003). 


\section{BIBLIOGRAPHY}

Wada, Yoko, 'What is Ancrene Wisse?' in Wada (ed.), Companion, pp. 1-28.

Warren, Ann K., Anchorites and their Patrons in Medieval England (Berkeley: University of California Press, 1985).

Warren, Ann K., 'The nun as anchoress: England 1100-1500', in Nicholls and Shank (eds), Distant Echoes, pp. 197-212 (pp. 203-4).

Watson, Nicholas, 'The methods and objectives of thirteenthcentury anchoritic devotion in Marion Glasscoe (ed.), The Medieval Mystical Tradition in England, Exeter Symposium IV, 1987 (Woodbridge: Brewer, 1987), pp. 132-46.

- 'Censorship and cultural change in late-medieval England: vernacular theology, the Oxford translation debate, and Arundel's Constitutions of 1409', Speculum, 70 (1995), 822-64.

—_ 'Middle English Mystics' in CHMEL pp. 539-65.

- 'Ancrene Wisse, religious reform and the late Middle Ages' in Wada (ed.), Companion, pp. 197-226.

Welter, J.-Th., L'Exemplum dans la Littérature Religieuse et Didactique du Moyen Age (Paris: Occitania, 1927).

Wilshere, Alan, 'The Latin primacy of St. Edmund's "Mirror of Holy Church"', The Modern Language Review, 71 (1976), 500-512.

Windeatt, Barry, English Mystics of the Middle Ages (Cambridge: Cambridge University Press, 1994).

Winston-Allen, Anne, Stories of the Rose: The Making of the Rosary in the Middle Ages (Pennsylvania: Pennsylvania State University Press, 1997).

Wogan-Browne, Jocelyn [Price], "Inner" and "Outer": conceptualizing the body in Ancrene Wisse and Aelred's De Institutione Inclusarum' in Gregory Kratzmann and James Simpson (eds), Medieval English Religious and Ethical Literature: Essays in Honour of G. H. Russell (Cambridge: D. S. Brewer, 1986), pp. 192-208.

— Saints' Lives and Women's Literary Culture c.1150-1300: Virginity and its Authorizations (Oxford: Oxford University Press, 2001).

Wogan-Browne, Jocelyn and Nicholas Watson, 'The French of England: the Compileison, Ancrene Wisse, and the idea of 
Anglo-Norman', Journal of Romance Studies, 4 (2004), 35-59.

Woods, Marjorie Curry and Rita Copeland, 'Classroom and confession', in CHMEL, pp. 376-406.

Woolf, Rosemary, The English Religious Lyric in the Middle Ages (Oxford: Clarendon Press, 1968).

\section{Reference works}

Baldick, Chris, The Concise Oxford Dictionary of Literary Terms (Oxford: Oxford University Press, 1990)

Concordance to Ancrene Wisse MS Corpus Christi College Cambridge 402, ed. by Jennifer Potts, Lorna Stevenson and Jocelyn Wogan-Browne (Cambridge: D. S. Brewer, 1993)

A Dictionary of Christian Spirituality, ed. by Gordon S. Wakefield (London: SCM Press, 1983)

Dictionnaire de Spiritualité Ascétique et Mystique, Doctrine et Histoire, fondé par M. Viller et al., continué par A. Derville et al., Tome 14 (Paris: Beauchesne, 1990)

Encyclopedia of the Middle Ages, 2 vols. ed. by André Vauchez et al., trans. by Adrian Walford (Cambridge: James Clarke, 2000)

Middle English Dictionary. ed. Hans Kurath (Ann Arbor, Mich.: University of Michigan Press, 1954-)

Oxford Dictionary of the Christian Church, ed. by F. L. Cross, 3th ed. by E. A. Livingstone (Oxford: Oxford University Press, 1997)

Oxford Dictionary of National Biography ed. by H. C. G. Matthew and Brian Harrison (Oxford: Oxford University Press, 2004)

Schneyer, J. B., Repertorium der Lateinischen Sermones des Mittelalters für die Zeit von 1150-1350, 9 vols. (Munster, 1969)

Victoria County History: Shropshire, vol. 2. 


\section{BIBLIOGRAPHY}

\section{Websites}

Fourth Lateran Council, trans. Norman Tanner at www.piar. hu/councils/ecum12.htm

Macy, Gary on Thomas of Chobham at http://home.sandiego. edu/ macy/Thomas\%20of\%20Chobham.html

Medieval Wall Painting in the English Parish Church: http:// www.paintedchurch.org/doomcon.htm

Payer, Pierre J. Introduction to Raymond of Penyafort, Summa on Marriage at www.pims.ca/pdf/mst41.pdf .

The Peraldus Project at 'The Peraldus Project' at http://www. english.upenn.edu/ swenzel/peraldus.html.

Simons W., 'The Beguine Movement in the Southern Low Countries; A Reassessment', at http://matrix.divinity.yale. edu/MatrixWebData/Simonsc.txt

Third Lateran Council, trans. Norman P. Tanner at http:// www.piar.hu/councils/ecum11.htm, 



\section{Index}

Aelred 7 see also De

Institutione Inclusarum

affective piety 9-10, 62 see

also lay piety

anchoritic spirituality, and

$$
\text { 50-1 }
$$

incarnational spirituality 62

allegory

preaching, and 109

anchoresses

anchoritic spirituality $50-61$

acceptance of suffering 56

affective piety 50

anchorhold 54

asceticism 58

Christ as lover 59

communion 59

crucifix 59

devotional practices 51

enclosure, meaning 54

imagery 53

Imitatio Christi 51

incarnational spirituality 52

liminality 52-3, 61

Mass 58

piety $50-1$

prayers and meditations

58

solitude $55,57-8$

virginity $56-7$

Ancrene Wisse, and 1-6

beguines compared 36-7, 44

contemplation, and see

contemplation enclosure of 44

harsher life, seeking 46-7 'lay' 47

authority of Church 48-9

literacy, and 47

meaning 47

mirror of God, as 170

rise in anchoritism 45-6

social and religious factors 46

Rule of St Benedict, in 46

social position of 44

Anchorhold

haven, as 54

internal space of 8

Ancren Riwle 2

Ancrene Wisse

adaptations 183-4

adaptability 188

anchoresses 1-2

community of 2

confession, and 3

education of 6

life of 3

references to 1

sexual practices, and 3

sexual purity of 3-4

anchorhold 8

anchoritic guide, as 7-8

asceticism 159-74

audience $3,10,181-2$

adaptation of material for 10

lay readership 10 


\section{INDEX}

authorship 5

Dominican 5

female 181

'casual antifeminism' 8

chief sins 122-3

Cistercian spirituality 52

influence of 52

contemplation 159-74 see also contemplation

penance, and 166

context of 11

dating 4,5

friars, mentions of 5

destinctiuns 96

dialect 185

essamples 152

exempla 151-8

'allegorical mode' 153

constitution of 153

similitudines distinguished 155

French translation 183

function 159

general tenor of 5-6

guidebook for women, as 36

humanism, context of 8

influence of 186-7

Inner Rule 53

language of 4 dialect 4

Latin invocations 55

lechery, on 122

meaning 1,2

relevant version 2

'the work', meaning 2

meditations 161-2

physicality of 162

metaphor of Christ 157

multifunctional nature $2-3$, 10-11

Outer Rule 53

palaeography 182

Passion of Christ, and 156

penitence 156-7 private prayers 66

provenance 182

quest for union with God 163

reading as vernacular

spirituality see

vernacular spirituality

rewards in 179-80

rhetoric of 139-58

essamples 152

exempla 151-8

forbisne 152-3

rhetorical questions 154

similitudines 151-8

structure 139-51

Scale of Perfection compared 177-81

sermon rhetoric, use of 112

similitudines 151-8

exempla distinguished 155

sins, treatment of 122

sources 1,139

spirituality of 9-10, 159

Cistercian tradition of 9

transitional position 11

structure 139-51

categories of temptation

146

conditions of confession

148

destinctiuns 139-40

dilatatio 151

forbisnes 143, 147

hierarchical division

140-1

monastic models 150

numbered orderliness 144

orderliness 140

organization of parts 141

Part Five, structure 147-8

Part Four, structure 144-5

Part Seven, form 150-1

Part Six 149

Part Two, organization of

141-2 


\section{INDEX}

pastoral literature, influence 141

patterns of imagery 143

penitence 149

references to other authors 150

similitudines 143

sub-themes, use of 143

suffering 124-5

texts associated with 91

Virgin Mary, devotions to 68 annual communion 25

confession, and 25

Apostles' Creed 99

apostolic life 21-2

interpretation of 21-2

Arrouaisians 21

artes praedicandi 100 see also preaching

asceticism 58, 159-74

contemplation, and 163-4

necessity of 173

meaning 164

Mystical Prayer 164

Augustinian order 21

Ave Maria 67-8

beguine movement 36

acts of penitence 45

anchoresses, similarities with 36-7

beguine sermons see beguine sermons

daily devotions 44-5

Dominican friars 40

ecclesiastical control 42

education 110

extreme behaviour 43-4

impact 40-1

Louis IX, support of 112-13

observations 45

'Psalter of the Virgin' 68-9

'riule' 45

sermons 44 social class 41

social and economic factors 42-3

social position 44

spiritual expression 36

'surplus' women 41

variety of 41-2

beguine sermons $110-18$

audience 110-11

collection of 110

education 110

elaborations 110

Hubert of Sorbonne 113

imagery 111, 118

language of 118

moderation 112

nature of man 116

penitence 113

preachers of 111

rhetoric 112

temptation 113

tribulations 115-16

virginity 115

Bernard of Clairvaux 56, 171, 181

Bible

study of 103

bishops 4

constitutions published by 4

blood of Christ 34

Books of Hours 69

bridal mysticism 32-3, 168

Carthusian order 21

Cathar heresy 28

Christ

crucifixion 63

human aspect 51

lover of anchoresses, as 59

metaphor of 157

Cistercian order 21

imitation of Christ's

humanity 51

nunneries $39-40$ 


\section{INDEX}

Clemence of Barking 55

clergy

authority of 20

pastoralia, and 97-8

clerics

education 23, 99

communion 59

anchoresses receiving 59

reluctance to take 64

ritual of $64-5$

Compileison 183

confession 3,125

annual communion, and 25

conditions of 148

intention, and 26

interior penitence 26

parish priest's role in 25

confessional treatises

two genres of 94

consent

role of 26

temptation, and 26

contemplation 159-74

availability 174

definition 160

use of term 160-1

devotions and penances 165-6

divine things, of 168-9

form of religious life 174

knowledge of God 171

life of asceticism, and 163-4

life of Mary 164-5

meditations, and 161

morning-gifts 170-1

personal discipline 166

progress, idea of 172-3

reform of soul 179

rewards for 170-1

Saint Augustine 167

sight of heaven 170

stages of contemplative life

172 starting position for 169

usefulness 178

Corpus Christi 34

devotion to body of Christ 62

crucifixes

anchoresses' 59

crux horribilis 67

increased use of 67

De Institutione Inclusarum 7, 56, 119

images in 155

influence of 7

knowledge of God 173

monastic tradition 91

mouvance 7

similitudines 155

Decretum of Gratian 140

Dilatatio 151

Distinctiones 102-4, 139-40

divisions 97, 139-41

texts, of 97, 139-41

Dominicans

arrival of 5

establishment of 28

pastoral duties 5

role 29

rule of Augustine 28

women's houses 40

'Doom' paintings 91

economic miracle

twelfth century 20

ecstatic experiences 35, 163

education 99-100

clerics 23

faith and morals, on 24

need for 24

parish priests, of $99-100$

enclosure 54

meaning 54

enthymeme 108-9 


\section{INDEX}

eucharistic theology 30-5

act of imitation, as 51

blood of Christ 34

bridal mysticism, and 32-3

bridal imagery 33

Christ-centred spirituality 34-5

concealment of Host 32

daily devotions 31

humanity of Christ, and 52

Juliana of Cornillon 34

Corpus Christi, and 34 piety of religious women 33 sacrament of altar 33-4

death of Christ, and 33-4

sacrament of Mass 31

transubstantiation, 30 see also transubstantiation exempla 107-8, 151-8

collections of 108

form of reasoning, as 107

preaching, and 108

Summa confessorum, in 95

female

gender imagery, use of 9

positive models, as 8-9

sign of weakness, as 8

Five Joys of Mary 188

food

language of love, and 33

forbisnes 143, 147

Fourth Lateran Council 4, 19-29

date of 19

decrees of $4-5,22-3$

authority to preach 23

Eucharist, and 30

first decree 22

imposition of order on religious houses 28

invention of new orders 26-7 movement for reform, and 23

promotion of 5

education on faith and morals 24

grammar, teaching of 100

heresy, definition 23

pastoral care of laity 24-5

preaching, and 99

preaching guides 100

reform programme 20

Established Church, outside 20

social context 20

theologian, requirements for 100

Franciscans

arrival of 5

role 29

friars 5

use of services of 29

gender imagery 9

Gertrude of Helfta 36

Glibert of Sempringham 38

Grosseteste 64

Guerric of Igny 56

Henry IV, Holy Roman

Emperor 20

heresy 22

Cathar 28

conversion of heretics 29

definition 23

prevalence of 185

threat of 22

authority of Church, and

22

Hilton, Walter 12, 177-81

Hours of the Virgin 44, 69

Hubert of Sorbonne 113

humanism

twelfth century 8 


\section{INDEX}

Ignorantia Sacerdotum 175

imagery

beguine sermons 111, 118

bridal 168

patterns of 143, 156

Imitatio Christi 51

incarnational spirituality 52

lay piety, and 65

intention

most important element in sin, as 25

James of Vitry 35, 37, 43-4

birth of beguines $37-8$

confessor of Mary of Oignies 38

eucharistic piety of women 33

language of Song of Songs

61

preaching, and 104-5

sermones ad vulgares 111

women, and 37-8

account of holy women 38

John of Wales

preaching, on 101

Judith 8-9

use of figure 8-9

Juliana of Cornillon 34

Katherine Group 70-1, 91-2

laity

pastoral care of 24-5

Langton, Archbishop Stephen 99-100

lay piety $11,62-71$

Ave Maria 67-8

Books of Hours 69

church and laity, relationship 62

crucifix, use of 67

crucifixion 63 cult of Virgin Mary 67-8

'Psalter of the Virgin' 68-9

devotions 65-6

elevation 63

homilies 66

Hours of the Virgin 69

incarnational spirituality 65

Lay Folks Mass Book 65

literacy, and 70

Mass, and 63, 65

new forms of 11

rosary 68

suffering and tribulation 66

lechery 122

Legenda Aurea 97

liminality 52-3

literacy

growing wealth, and 21

levels of 70

meaning 70

literature

pastoral see pastoral literature

Lollard interpolation 185

Lord's Prayer 99

love

language of 33 food, and 33

Mary Magdalene 165

Mary of Oignies 35

Mass 31

anchoresses 58

lay people at 63

mystery, as 65

prayers to say during 32

rood-screen 65

sacrament of 31

Mechthild of Magdeburg 36

medieval texts

editing 182

mouvance 7

variability of $6-7$ 
INDEX

\author{
Meditationes Vitae Christi \\ 187-8 \\ meditations 161 see also \\ contemplation \\ role 161 \\ visionary experiences 162 \\ Mendicant orders 11, 28 \\ approval of 28 \\ authority of Church, and 29 \\ foundation of 11 \\ Imitatio Christi, and 51 \\ metaphors \\ preaching, and 107 \\ Middle English Mystics

$$
\text { 159-60 }
$$ \\ Miraculous Hosts 34 \\ Mirror of the Blessed Life of \\ Jesus Christ 187-8 \\ reference to Ancrene Wisse \\ 187 \\ morning-gifts 170-1 \\ mouvance 7 \\ definition 7 \\ mysticism 177
}

New Scholarship 208

Odo of Cheriton 93

Office of the Virgin 69

Books of Hours, and 69

Order of Preachers

beginning of 28-9

Outer Rule 6

observances of 6

parish priests

duties 99

Parker, Archbishop Matthew 189

Passion of Christ 51, 56, 156

pastoral literature 119-25

chief sins 122-3

Fourth Lateran Council, influence 124 influence on Ancrene Wisse 141

influential treatises 120-1

'lay instruction' 123

moral theology of Paris, and 123-4

penitential literature 123

universities, and 120

vernacular languages, in

$119,122-3$

vices and virtues, on 120

pastoralia 91-8

influence of 92

meaning 92

parish priests $97-8$

rhetoric of 96 distinctiones 96 structure of 96

schools, and 92-3

structure of texts $96-7$ division 97

Summa confessorum 94

Pecham, Archbishop 175

penance

imposition of 25

priest performing 25

penitentials 93

Pennaforte, Raymond 120-1

Peraldus, William 121

piety

lay 11

popular 21

'Poor Catholics' 22

'Poor Men of Lyons' 22

Pope Gregory VII 19-20

clash with Holy Roman

Emperor 20

reforms of 19-20

Pope Innocent III 20

education 93

practical ethics 93

Pope Lucius III 22

preaching

allegory 109 


\section{INDEX}

biblical references 107

distinctiones 102

nubes 103

enthymeme 108-9

Fourth Lateran Council, and 99

James of Vitry, and 104-6

language of 109

metaphors 107

preaching guides 100-1 artes praedicandi 100

rhetoric of 99-109

study of Bible, and 103-4

chains of images 104

immersion in Scriptures

103

similitudines 104

summa de arte praedicandi 101-2

classical rhetorical devices 102

divisio 102

division of words 102

Sunday sermons 105

Thomas of Chobham 106 unauthorized 22

appointment of preachers 23

Fourth Lateran Council decree 23

university sermon 100-1

Premonstratensians 21

female communities 39

Prémontré statutes 140

Psalter of the Virgin 68-9

reading circles 187

religion

meaning 26

religious orders

defining 27

unauthorized 26

religious reform 20

wider social context 20

within Church 21
Richard of St Victor 166

Robert of Arbrissel 38

rosary

lay piety, and 68

Saint Augustine 167

Sawles Warde 91-2

Scale of Perfection 12, 177-80

schools

development of pastoralia, and $92-3$

sermons

beguine see beguine sermons forms of 100-1 development of new 100 sexual practices 3

similitudines 104, 143, 151-8

society

urban nature of 21

Somme le Roy 123

Song of Songs 56, 168

language of 61

Stavensby, Alexander 4-5

suffering 66 importance of 124-5

Summa casuum poenitentiae 120-1

legalistic tone of 121

Summa confessorum 94-5

audience 98

exempla 95

Summa de arte praedicandi 101-2

Synod of Paris 32

textual study 182

The Chastising of God's

Children 186

Thomas of Chobham 94, 101

sermons 106-7

trade

inceptio 107

dependence on 21

exchange of ideas, and 21 


\section{INDEX}

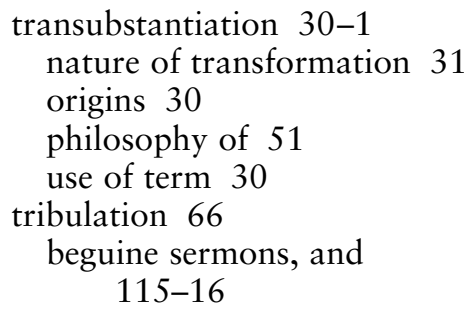

\section{Verbum Abbreviatum 24}

vernacular spirituality 175-89

English vernacular theology

$$
\text { 175-6 }
$$

fourteenth-century mysticism 177

meaning 176 spirituality, meaning 176-7

Vices and Virtues 119, 121

Virgin Mary, cult of 67-8

virginity

anchoresses, of 56-7

beguine sermons, and 115 visions 162

Vitae Fratrum 121
Waldensian movement 21, 22 preaching 22

split 22

way of life 22

women see also female eucharistic piety of 33

Christ-centred spirituality 34-5

ecstatic experiences 35

female religious movement 36-49 see also anchoresses

beguine movement 36 see also beguine movement Cistercian order 39-40 control of 39-40 economic and social factors 42-3 houses for women 38 male patrons 37 married women 43 misogynistic attitudes of church leaders 37 scandal, and 38-9 single-sex foundations 39 vulnerability of 40 learning 70 quasi-clerical roles 37 translation of texts 184 Wooing Group 71, 91-2 




